UNIVERSIDADE DE SÃO PAULO

FACULDADE DE ECONOMIA, ADMINISTRAÇÃO E CONTABILIDADE DE RIBEIRÃO PRETO

Dissertação de Mestrado:

Desenvolvimento Sistêmico de Pólos Regionais de Tecnologia da Informação: Análise Comparativa entre Modelos de Clusters Nacionais e Internacionais Sob a Perspectiva da Teoria dos Sistemas

CHRISTIAN CARVALHO GANZERT

Ribeirão Preto

2010 
CHRISTIAN CARVALHO GANZERT

\section{Desenvolvimento Sistêmico de Pólos Regionais de Tecnologia da Informação: Análise Comparativa entre Modelos de Clusters Nacionais e Internacionais Sob a Perspectiva da Teoria dos Sistemas}

Dissertação de Mestrado apresentada à
Faculdade de Economia, Administração e
Contabilidade de Ribeirão Preto da Universidade
de São Paulo, para obtenção do título de Mestre
em Administração de Organizações, pelo curso
de Pós-Graduação em Administração de
Organizações. Área de concentração: Desenvolvimento Regional.

Orientador: Prof. Dr. Dante Pinheiro Martinelli.

Ribeirão Preto 
AUTORIZO A REPRODUÇÃO TOTAL OU PARCIAL DESTE TRABALHO, POR QUALQUER MEIO CONVENCIONAL OU ELETRÔNICO, PARA FINS DE ESTUDO E PESQUISA, DESDE QUE CITADA A FONTE.

Catalogação na Publicação

Biblioteca Central de Ribeirão Preto

Universidade de São Paulo

Ganzert, Christian Carvalho

Desenvolvimento Sistêmico de Pólos Regionais de Tecnologia da Informação: Análise Comparativa entre Modelos de Clusters Nacionais e Internacionais Sob a Perspectiva da Teoria dos Sistemas / Christian Carvalho Ganzert; orientador Dante Pinheiro Martinelli. Ribeirão Preto, 2010.

206 f. : 3 fig.

Dissertação de Mestrado (Programa de Pós-Graduação em Administração de Organizações. Área de Concentração: Desenvolvimento Regional) - Faculdade de Economia, Administração e Contabilidade de Ribeirão Preto, Universidade de São Paulo.

1. 2. 3. I. Título

CDU 338.4 


\section{FOLHA DE APROVAÇÃO}

Christian Carvalho Ganzert

Desenvolvimento Sistêmico de Pólos Regionais de Tecnologia da Informação: Análise Comparativa entre Modelos de Clusters Nacionais e Internacionais Sob a Perspectiva da Teoria dos Sistemas

Dissertação de Mestrado apresentada à Faculdade de Economia, Administração e Contabilidade de Ribeirão Preto da Universidade de São Paulo, para obtenção do título de Mestre em Administração de Organizações, pelo curso de Pós-Graduação em Administração de Organizações. Área de concentração: Desenvolvimento Regional.

Aprovado em:

\section{Banca Examinadora:}

Instituição: Assinatura:

Instituição: Assinatura:

Instituição: Assinatura: 
Dedico este trabalho aos integrantes do pequenino núcleo da família Ganzert em São Carlos, Andréa Júlia, Júlia ou Thomas (ainda não sabemos), e os felpudos Kimo e Nina. Que este esteja à altura de uma boa justificativa pelas possíveis ausências nos últimos dois anos. 


\section{AGRADECIMENTOS}

Agradeço ao Prof. Dr. Dante Pinheiro Martinelli pelas inúmeras oportunidades de aprendizado oferecidas ao longo da trajetória que objetivou essa dissertação.

Agradeço aos amigos Saulo Rodrigues, Leonardo Terra, Helenita Tamashiro, Giuliano Alves Borges e Silva, Glauce Costa de Almeida, Iraci João, Luiz Flávio Bezerra, Marcelo Venturi, Anderson Romanello e Cleber Camacho, generosos intermediários de oportunidades profissionais e de moradias que me permitiram a conclusão de mais essa etapa acadêmica, mesmo sem o apoio de instituições de fomento.

Agradeço aos dirigentes da Ciatec e do Parqtec, em especial ao Prof. Dr. Sylvio Goulart Rosa Jr. (Presidente do Parqtec) e ao Sr. Décio Sirbone Jr. (Diretor da Ciatec), cuja simpatia e disponibilidade me valeram a obtenção de valorosas informações para a conclusão desta pesquisa.

Agradeço à reitora da Escola de Informação da Universidade de Berkeley, Dra. AnnaLee Saxenian, cujas pesquisas sobre o Vale de Santa Clara e Bangalore e seu desprendido suporte a distância influenciaram na constituição da visão sistêmica que margeou a conclusão desse texto final.

Por fim, agradeço aos amigos que me inspiraram na continuidade de minha trajetória acadêmica, os Professores Marco Antonio de Almeida, João Luiz Passador, Janaina Giraldi, Giulia Crippa, Lucília Romão, Carlos Alberto Campello, Marcos Dantas e outros tantos que direta ou indiretamente influenciaram na obtenção de um estilo de trabalho. 
"É de grande ajuda pensar sobre um sistema industrial regional como possuidor de três dimensões: instituições locais e cultura, estrutura industrial, e organização corporativa. Instituições regionais incluem organizações públicas e privadas, assim como universidades, associações de negócios, e governo local, assim como os muito menos formais clubes de hobby, sociedades profissionais, e outros fóruns que criam e sustentam padrões regulares de interação social em uma região. Estas instituições moldam e são moldadas pela cultura local, os entendimentos compartilhados e práticas que uniformizam uma comunidade e definem tudo desde o comportamento do mercado de trabalho até as atitudes diante do risco. Uma cultura regional não é estática, mas é continuamente reconstruída pela interação social."

AnnaLee Saxenian

(SAXENIAN, 1994, p. 7) 


\section{RESUMO}

GANZERT, C. C. Desenvolvimento Sistêmico de Pólos Regionais de Tecnologia da Informação: Análise Comparativa entre Modelos de Clusters Nacionais e Internacionais Sob a Perspectiva da Teoria dos Sistemas. 2010. 206 f. Dissertação de Mestrado Faculdade de Economia, Administração e Contabilidade de Ribeirão Preto, Universidade de São Paulo, Ribeirão Preto, 2010.

Tendo como justificativa a relevância econômica dos arranjos produtivos regionais no capitalismo informacional, a pesquisa se propôs a analisar os modelos de desenvolvimento de quatro pólos regionais de tecnologia da informação, dois internacionais e dois nacionais, sob a perspectiva do conceito de desenvolvimento sistêmico. Os pólos abordados foram do Vale do Silício (Califórnia), Bangalore (Índia), Campinas e São Carlos (Brasil). Foi utilizada a metodologia de análise qualitativa cross-case de múltiplos casos. Os resultados foram comparados com o modelo ideal de desenvolvimento sistêmico. Como conclusão, foi possível verificar que os clusters nacionais funcionam sob poucos valores voltados para $\mathrm{o}$ empreendedorismo, o que culminou no estabelecimento de modelos mononucleados de relações entre agentes, diferente dos modelos multinucleados observados nos clusters internacionais, mais próximos das premissas do desenvolvimento sistêmico.

Palavras-Chave: Desenvolvimento Regional, Pólos Tecnológicos, Tecnologia da Informação, Agrupamentos Produtivos, Clusters Tecnológicos, Parques Tecnológicos. 


\begin{abstract}
GANZERT, C. C. Systemic Development of Information Technology Regional Poles: Comparative Analysis of National and International Models of Clusters by the Perspective of the Systems Theory. 2010. 206 f. Master Thesis - Faculty of Economics, Management and Accounting of Ribeirão Preto, University of São Paulo, Ribeirão Preto, 2010 .

This research is justified by the economic relevance of the regional productive arrangements for the informational capital, and analyses the development's model of four regional information technology poles, Silicon Valley (California), Bangalore (India), São Carlos and Campinas (Brazil). The research was developed using the qualitative multiple cross-case analysis methodology and the results were compared with the ideal model of systemic development. The conclusion signalizes the low incidence of entrepreneurship elements in the Brazilian organizational culture, which corroborates to the formation of mono-nucleated models of relations among the national clusters' agents, contrasting to the international clusters, which have multi-nucleated models of relations among their agents, closer to the systemic development premises.
\end{abstract}

Key-words: Regional Development, Technological Poles, Information Technology, Production Arrangements, Technological Clusters, Technological Parks. 


\section{SUMÁRIO}

1. INTRODUÇÃO

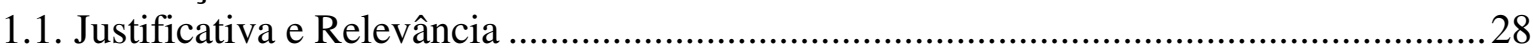

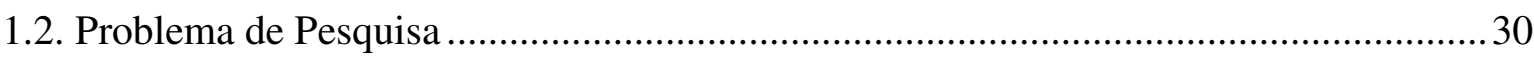

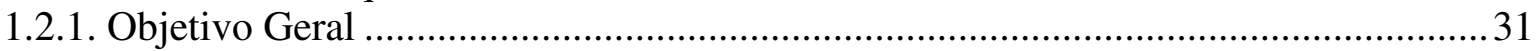

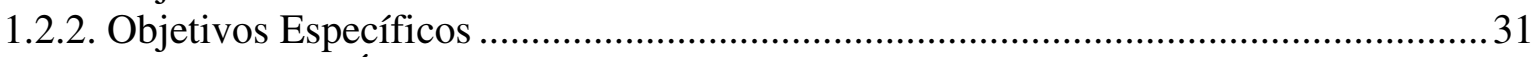

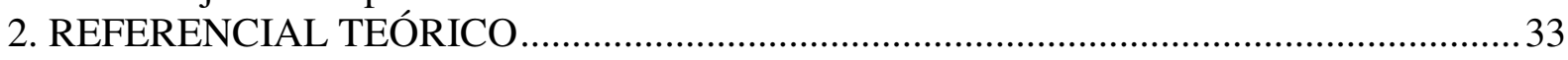

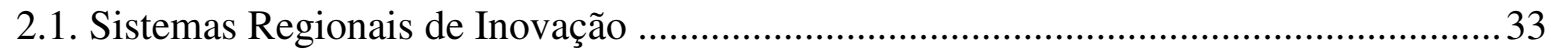

2.2. Pensamento Sistêmico Aplicado ao Conceito de Cluster ................................................ 41

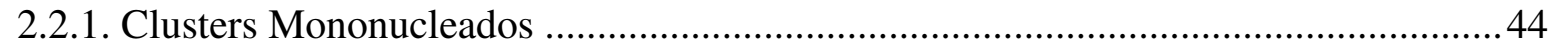

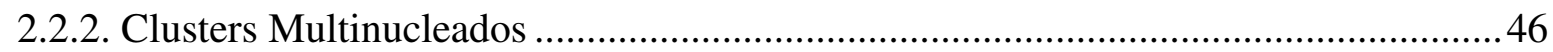

2.2.3. Complexidade das relações em um cluster............................................................... 48

2.2.4. O Conceito de Desenvolvimento Sistêmico ................................................................50

2.3. Taxonomia dos Arranjos Produtivos: a busca pela diferenciação conceitual entre

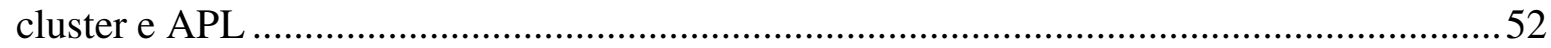

2.3.1. Outras estruturas de aglomeração regional de empresas ........................................57

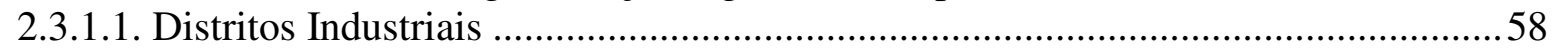

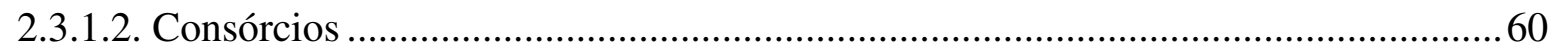

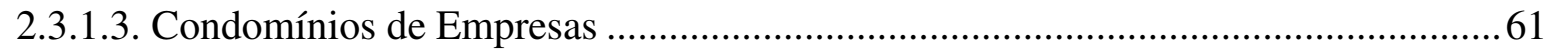

2.3.2. Mapeamento conceitual hierárquico dos tipos de agrupamentos abordados...............64

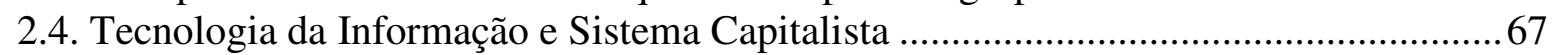

2.5. Apresentação dos Clusters de Tecnologia de Informação Abordados ..........................78

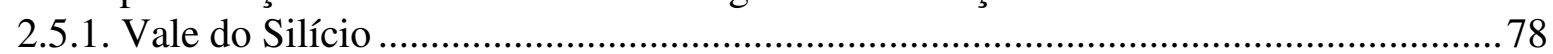

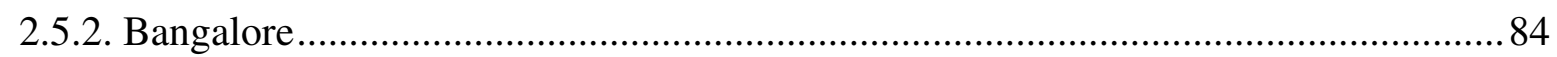

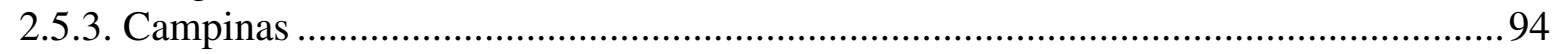

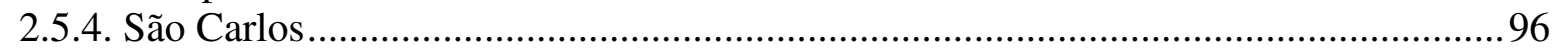

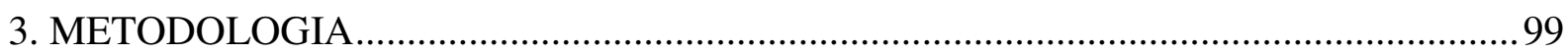

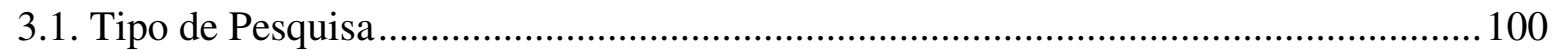

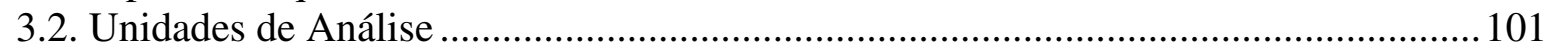

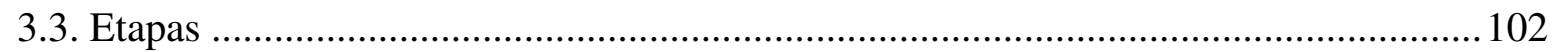

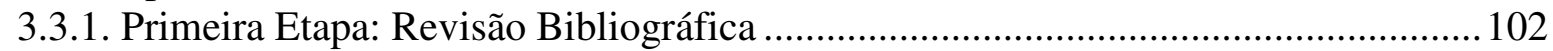

3.3.2. Segunda Etapa: Prospecção em Campo ……............................................................... 103

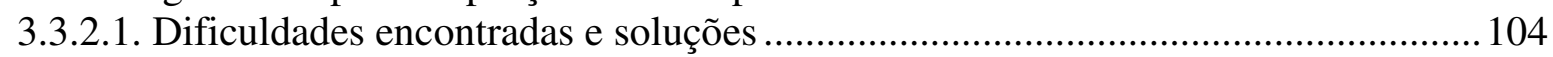

3.3.2.2. Justificativa da escolha das fontes de pesquisa de campo .................................... 105

3.3.3. Terceira Etapa: Avaliação, Classificação e Tabulação de Dados............................. 107

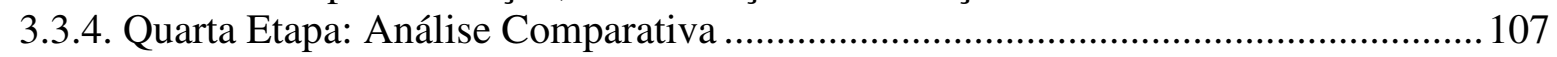

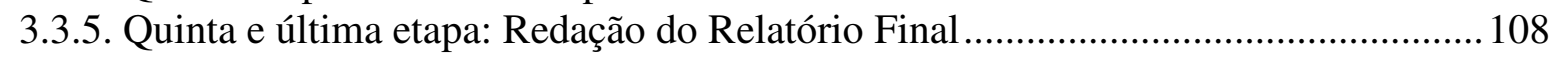

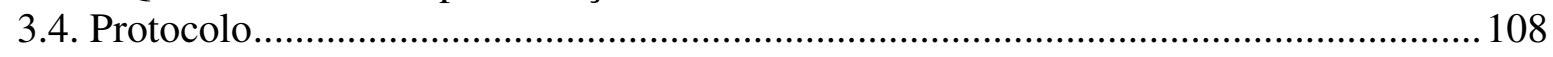

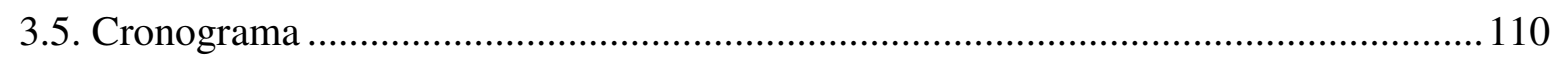

4. RESULTADOS DA PESQUISA DOS CLUSTERS INTERNACIONAIS .....................111

4.1. Respostas ao instrumento de pesquisa sobre o Vale do Silício ....................................111

4.1.1. Como se deu o processo histórico de desenvolvimento do Vale do Silício? ............ 112

4.1.2. Quais as características econômicas que propiciaram o surgimento do cluster no Vale

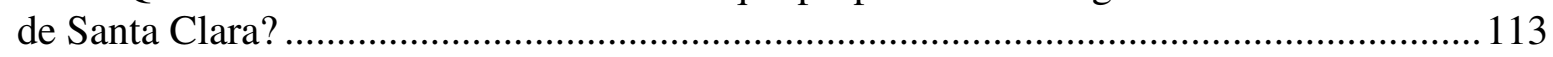

4.1.3. Como se deram as relações entre governos, instituições de ensino, institutos de pesquisa e empreendedores na concepção e implantação do cluster? ............................... 113 4.1.4. Qual a relação entre o estabelecimento do Vale do Silício e o volume de mão de obra especializada disponível na região?. 
4.1.5. Quais os tipos de relações estabelecidas entre as empresas do Vale do Silício e como elas se dão? Existe predominância de algum dos tipos sobre os outros?

4.1.6. Há relação de hierarquia, evidenciando um grau de importância de uma empresa frente às outras, nos processos produtivos ou nas diversas relações estabelecidas entre as empresas do Vale do Silício?

4.1.7. Qual a participação inicial do Vale do Silício no volume de negócios do setor de TI?

4.1.8. Como se estabeleceu a rede de relações entre os agentes do Vale do Silício (empresas e pessoas) após o início de suas atividades?

4.1.9. Como se dá o fluxo de transferência de conhecimento entre as empresas do Vale do Silício, entre agentes de outros Sistemas Regionais de Inovação e mesmo entre agentes de outros Sistemas Nacionais de Inovação?

4.1.10. Entre os sub-setores da Tecnologia da Informação (software, serviços, semicondutores, etc.), quais aqueles que obtiveram destaque entre os empreendimentos estabelecidos no Vale do Silício, tanto por seu volume de negócios como por sua excelência em inovações para o mercado?

4.1.11. Qual a importância do poder público e da legislação vigente para a manutenção do Vale do Silício?.

4.1.12. Qual a posição sócio-econômica da região onde o Vale do Silício está estabelecido frente ao padrão americano e aos padrões das regiões dos demais pólos tecnológicos do mesmo setor (limitando-se aos estudados)?....

4.1.13. Há relação entre os fatores de desenvolvimento social da região com o pólo tecnológico?

4.1.14. Como o pólo tecnológico se integra com o desenvolvimento de pesquisa científica da região que ocupa? Qual sua participação no estabelecimento de implementos educacionais da região?

4.2. Respostas ao instrumento de pesquisa sobre Bangalore

4.2.1. Como se deu o processo histórico de desenvolvimento do cluster de Bangalore?.. 122

4.2.2. Quais as características econômicas que propiciaram o surgimento do cluster na região de Bangalore?

4.2.3. Como se deram as relações entre governos, instituições de ensino, institutos de pesquisa e empreendedores na concepção e implantação do cluster de Bangalore?

4.2.4. Qual a relação entre o estabelecimento do cluster e o volume de mão de obra especializada disponível na região?

4.2.5. Quais os tipos de relações estabelecidas entre as empresas do cluster de Bangalore e como elas se dão? Existe predominância de algum dos tipos sobre os outros?.

4.2.6. Há relação de hierarquia, evidenciando um grau de importância de uma empresa frente às outras, nos processos produtivos ou nas diversas relações estabelecidas entre as empresas do cluster?

4.2.7. Qual a participação inicial de Bangalore nos volumes de negócios de seus setores?

4.2.8. Como se estabeleceu a rede de relações entre os agentes do pólo de Bangalore (empresas e pessoas) após o início de suas atividades?

4.2.9. Como se dá o fluxo de transferência de conhecimento entre as empresas de

Bangalore, entre agentes de outros Sistemas Regionais de Inovação e mesmo entre agentes de outros Sistemas Nacionais de Inovação?

4.2.10. Entre os sub-setores da Tecnologia da Informação (software, serviços, semicondutores, etc.), quais aqueles que obtiveram destaque entre os empreendimentos estabelecidos em Bangalore, tanto por seu volume de negócios como por sua excelência em inovações para o mercado? 
4.2.11. Qual a importância do poder público e da legislação vigente para a manutenção do pólo tecnológico?

4.2.12. Qual a posição sócio-econômica da região onde o cluster de Bangalore está estabelecido frente ao padrão nacional e aos padrões das regiões dos demais pólos tecnológicos do mesmo setor (limitando-se aos estudados)?

4.2.13. Há relação entre os fatores de desenvolvimento social da região com o pólo tecnológico?.

4.2.14. Como Bangalore se integra com o desenvolvimento de pesquisa científica da região que ocupa? Qual sua participação no estabelecimento de implementos educacionais da região?

5. RESULTADO DA PESQUISA DOS CLUSTERS NACIONAIS …..............................135

5.1. Respostas ao instrumento de pesquisa sobre Campinas ............................................. 136

5.1.1. Como se deu o processo histórico de desenvolvimento do pólo tecnológico de Campinas?

5.1.2. Quais as características econômicas que propiciaram o surgimento do cluster na região de Campinas?

5.1.3. Como se deram as relações entre governos, instituições de ensino, institutos de pesquisa e empreendedores na concepção e implantação do cluster de Campinas?

5.1.4. Qual a relação entre o estabelecimento do cluster e o volume de mão de obra especializada disponível na região?

5.1.5. Quais os tipos de relações estabelecidas entre as empresas do pólo de tecnologia e como elas se dão? Existe predominância de algum dos tipos sobre os outros?

5.1.6. Há relação de hierarquia, evidenciando um grau de importância de uma empresa frente às outras, nos processos produtivos ou nas diversas relações estabelecidas entre as empresas do cluster de Campinas?

5.1.7. Qual a participação inicial do cluster de Campinas nos volumes de negócios de seus setores?

5.1.8. Como se estabeleceu a rede de relações entre os agentes do pólo de tecnologia de Campinas (empresas e pessoas) após o início de suas atividades?....

5.1.9. Como se dá o fluxo de transferência de conhecimento entre as empresas do cluster de Campinas, entre agentes de outros Sistemas Regionais de Inovação e mesmo entre agentes de outros Sistemas Nacionais de Inovação? .

5.1.10. Entre os sub-setores da Tecnologia da Informação (software, serviços, semicondutores, etc.), quais aqueles que obtiveram destaque entre os empreendimentos estabelecidos no cluster de Campinas, tanto por seu volume de negócios como por sua excelência em inovações para o mercado?

5.1.11. Qual a importância do poder público e da legislação vigente para a manutenção do pólo tecnológico?.

5.1.12. Qual a posição sócio-econômica da região de Campinas frente ao padrão nacional e aos padrões das regiões dos demais pólos tecnológicos do mesmo setor (limitando-se aos estudados)?

5.1.13. Há relação entre os fatores de desenvolvimento social da região com o pólo tecnológico?

5.1.14. Como o pólo tecnológico de Campinas se integra com o desenvolvimento de pesquisa científica da região que ocupa? Qual sua participação no estabelecimento de implementos educacionais da região?

5.2. Respostas ao instrumento de pesquisa sobre São Carlos.

5.2.1. Como se deu o processo histórico de desenvolvimento do pólo tecnológico de São Carlos? 
5.2.2. Quais as características econômicas que propiciaram o surgimento do cluster na região de São Carlos?.

5.2.3. Como se deram as relações entre governos, instituições de ensino, institutos de pesquisa e empreendedores na concepção e implantação do cluster?

5.2.4. Qual a relação entre o estabelecimento do cluster e o volume de mão de obra especializada disponível na região de São Carlos?

5.2.5. Quais os tipos de relações estabelecidas entre as empresas do pólo de tecnologia de São Carlos e como elas se dão? Existe predominância de algum dos tipos sobre os outros?

5.2.6. Há relação de hierarquia, evidenciando um grau de importância de uma empresa frente às outras, nos processos produtivos ou nas diversas relações estabelecidas entre as empresas do pólo tecnológico de São Carlos?

5.2.7. Qual a participação inicial do cluster de São Carlos nos volumes de negócios de seus setores?

5.2.8. Como se estabeleceu a rede de relações entre os agentes do pólo de tecnologia de São

Carlos (empresas e pessoas) após o início de suas atividades?.

5.2.9. Como se dá o fluxo de transferência de conhecimento entre as empresas do cluster de São Carlos, das empresas do cluster com agentes de outros Sistemas Regionais de Inovação e mesmo com agentes de outros Sistemas Nacionais de Inovação?

5.2.10. Entre os sub-setores da Tecnologia da Informação (software, serviços, semicondutores, etc.), quais aqueles que obtiveram destaque entre os empreendimentos estabelecidos no cluster de São Carlos, tanto por seu volume de negócios como por sua excelência em inovações para o mercado?

5.2.11. Qual a importância do poder público e da legislação vigente para a manutenção do pólo tecnológico de São Carlos?

5.2.12. Qual a posição sócio-econômica da região onde o pólo tecnológico de São Carlos está estabelecido frente ao padrão nacional e aos padrões das regiões dos demais pólos tecnológicos do mesmo setor (limitando-se aos estudados)?....

5.2.13. Há relação entre os fatores de desenvolvimento social da região de São Carlos com o pólo tecnológico?

5.2.14. Como o pólo tecnológico de São Carlos se integra com o desenvolvimento de pesquisa científica da região que ocupa? Qual sua participação no estabelecimento de implementos educacionais da região?

6. ANÁLISE COMPARATIVA ENTRE CLUSTERS (CROSS-CASE) .............................. 159

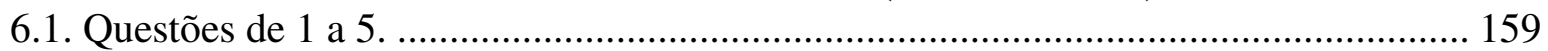

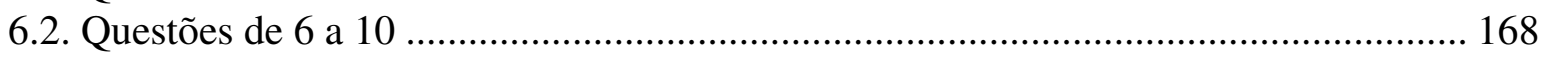

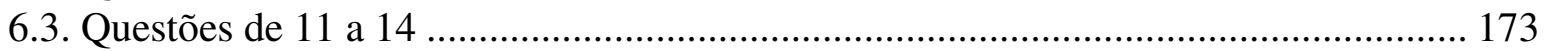

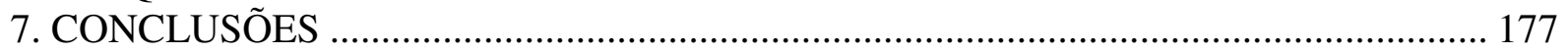

7.1. Limitações de Pesquisa .............................................................................................. 182

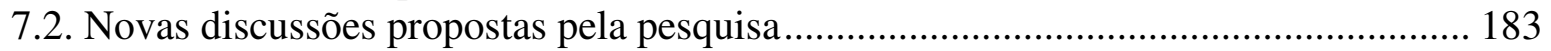

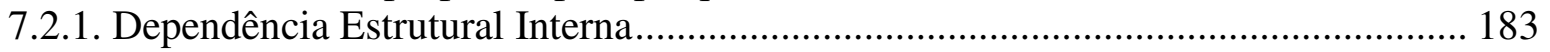

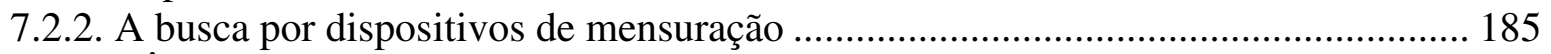

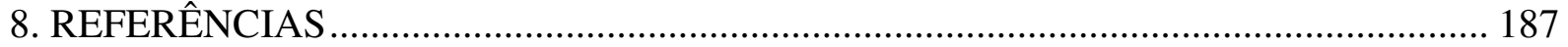

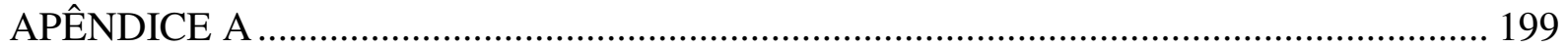

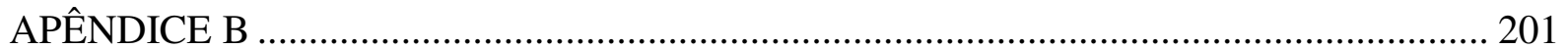

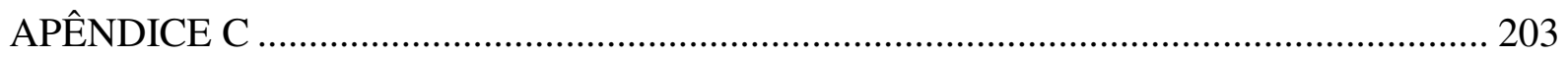




\section{INTRODUÇÃO}

A importância da Indústria de Tecnologia da Informação (ou simplesmente TI) para a sociedade contemporânea é notória, principalmente frente às mudanças estruturais ocorridas no sistema capitalista nos últimos quarenta anos. A integração necessária ao movimento de expansão global dos mercados somente se fez possível através do aparato tecnológico de comunicação emergido após a invenção dos circuitos integrados e, em seguida, dos computadores (LOJKINE, 2002).

A Tecnologia da Informação é advinda da descoberta de novos processos de comunicação e processamento de informações através da utilização de mecanismos eletrônicos. Há várias definições dadas ao termo, sendo que para Furtado (2002) é “todo recurso tecnológico e computacional destinado à coleta, manipulação, armazenamento e processamento de dados e/ou informações dentro de uma organização" (FURTADO, 2002). Souza et al. (2007) defende que a TI é "o conjunto de recursos não humanos dedicados ao armazenamento, processamento e comunicação da informação, e a maneira como esses recursos estão organizados num sistema capaz de executar um conjunto de tarefas" (SOUZA et al., 2007). A definição de Buckland (1991) parece mais simples e completa, para a qual TI é "qualquer tecnologia usada para lidar com informação" (BUCKLAND, 1991, p. 69). Porém, quando direcionado ao modelo de Tecnologia da Informação relevante para a sociedade contemporânea, Buckland (1991) limita seu conceito à tecnologia que "faz progresso no oferecimento de ferramentas mais potentes e baratas" (BUCKLAND, 1991, p. 75) para lidar com a informação - neste rol estão as ferramentas eletrônicas.

Pelo conceito de Buckland (1991), a indústria de Tecnologia da Informação do século XIX estaria ligada ao setor gráfico, responsável pela produção de livros e ferramentas para armazenamento e comunicação da informação. Talvez, de forma mais abrangente, poderiam estar relacionados ao setor, naquela época, a indústria de canetas-tinteiro ou lápis, e mesmo os produtores de máquinas para impressão. Entretanto, após a segunda metade do século XX, uma nova indústria de Tecnologia da Informação emergiu, com a chegada ao mercado dos recursos eletrônicos de informação (LOJKINE, 2002). Esta nova indústria encontrou seu marco inicial no advento do transistor pela Bell Labs, em 1946 (CHANDLER; CORTADA, 2003). De descoberta em descoberta, o setor chegou ao seu símbolo de identificação, o computador. Ainda que o primeiro computador houvesse sido idealizado por Babbage ainda 
no século XIX (GARDNER, 1996) e desenvolvido pela Universidade da Pensilvânia em 1945, o ENIAC de Mauchly e Eckert (CAVALCANTI, 1996), foi com o surgimento do transistor que a tecnologia decolou (CASTELLS, 1999). Após a incorporação do silício na fabricação de transistores, houve um salto significativo de produtividade. $O$ setor de fabricação de componentes eletrônicos baseados em silício e materiais semelhantes passou a se denominar de setor de semicondutores (alcunha baseada na característica material dos insumos de seu produto), ocupado por uma nova indústria baseada no conhecimento (CASTELLS, 1991). A indústria de semicondutores surgiu como provedora de matéria-prima para a indústria de computadores, "muito maior e mais diversificada que a indústria de semicondutores" (CASTELLS, 1991, p. 57). A indústria de semicondutores é responsável pela parte de maior relevância do hardware, a parte física, dos produtos da indústria de computadores, e ainda que não tenha a amplitude das indústrias com que se relaciona, é o ponto de intersecção entre todas as indústrias do setor de TI (KEKLIK, 2003).

Podemos enxergar a indústria de TI, dessa forma, como um amálgama de outras indústrias, que tem como eixo central a produção de semicondutores e, ligada a ela, toda uma gama de desdobramentos em produtos e serviços. Esse amálgama se comporta dinamicamente como um complexo sistema de agentes e relações, formando uma cadeia produtiva com vários resultados de saída (SAXENIAN, 1994).

Os setores mais importantes que compõem a indústria de TI são os de hardware (onde está a indústria de semicondutores), o de software (que produz programas e rotinas para o funcionamento dos equipamentos) e de serviços (indústria que se concentra nas aplicações específicas do que é desenvolvido pelas duas indústrias iniciais), interdependentes um do outro (OZ, 2005). A indústria de TI, dessa forma, é mais ampla e complexa do que a simples produção de componentes ou de computadores, uma vez que sua cadeia produtiva se conecta com as mais diversas cadeias da economia contemporânea. Hoje a TI é fundamental para todas as outras indústrias de produção em larga escala ou que envolvam alta tecnologia em sua produção. Mesmo aquelas indústrias mais tradicionais, que escapam à dependência da TI, estão relacionadas aos fatores adidos pela TI à cultura (SANTAELLA, 2003).

O impulso dado à produção de toda a economia global pelos recursos oferecidos pela indústria de TI foi ímpar, nunca observado em nenhuma outra mudança de paradigma tecnológico da história humana (LOJKINE, 2002). Novos meios de comunicação e difusão de informações foram concebidos através do uso dos computadores, ampliando o fluxo informacional e conectando áreas remotas do planeta. Isso favoreceu a integração dos mercados e o surgimento de uma espécie de "cultura do meio" (SANTAELLA, 2003), uma 
conjunção de elementos culturais em torno do aparato tecnológico de informação. A grande representação desses novos meios de comunicação, surgida para o uso público na década de 1990, é a internet (CASTELLS, 1999). Entretanto, a figura do computador, conectado à internet, está cada vez mais dissociada da original máquina de trabalho com unidade de processamento e periféricos. A convergência digital - fenômeno que impulsiona a integração de vários dispositivos distintos em torno do aparato de comunicação digital - está a cada dia distanciando a TI de sua imagem restrita ao computador. Celulares, televisores e videogames já estão conectados à mesma rede em que outrora habitavam hegemônicos os computadores (STRABHAAR, 2004). Cada vez mais, a TI encontra espaço no cotidiano social, transformando o ser humano e seu comportamento, tanto no aspecto produtivo e econômico quanto no aspecto social.

Pela razão de ter transformado as relações produtivas, os relacionamentos sociais e a cultura de quase a totalidade das sociedades humanas, a indústria de TI é o emblema do novo modelo de capitalismo existente nos dias de hoje, no qual a informação se transformou no principal produto das economias desenvolvidas. O informacionalismo, termo que designa a nova fase do sistema econômico capitalista, está apoiado sobre a Tecnologia de Informação, e diretamente relacionado à indústria de TI (LOJKINE, 2002), assim como a primeira fase do capitalismo industrial se apoiava sobre a tecnologia da máquina a vapor (HOBSBAWN, 2006). O informacionalismo é conceituado por Lojkine (2002) como um dos frutos da fase pós-industrial do capitalismo, quando a informação passou a ser o produto mais relevante do sistema. Esse conceito se baseia na idéia de que o capitalismo teve três estágios principais, o mercantilismo, o industrialismo e, atualmente, o informacionalismo, todos mediados por períodos de transição bem específicos (LOJKINE, 2002). Essa mesma divisão é encontrada na análise de Castells (1999), na qual o informacionalismo é tido como a Era da Informação.

A importância da indústria de TI não está somente no fornecimento de subsídios para a dinamização da produção em todos os demais setores, mas também na emergência de novas técnicas de administração de recursos e relações produtivas no que tange à própria produção de ferramentas tecnológicas de informação, físicas ou não. Especialmente entre os anos 1970 e 1980, quando a indústria de TI já estava consolidada como uma realidade no plano econômico mundial, novos modelos de organização produtiva começaram a emergir, principalmente de uma região marcada pelo empreendedorismo desde o início da década de 40. Tratavam-se das empresas da área batizada como "Vale do Silício", localizada na Califórnia, no Vale de Santa Clara, ao sul da região de São Francisco. 
A indústria de TI do Vale do Silício inovou administrativamente, principalmente se comparadas às mega-corporações tecnológicas situadas no resto do país. Na região de Santa Clara, empresas nascidas em garagens, gerenciadas por jovens recém formados, passaram a articular-se produtivamente para competir em mercados de nível nacional e internacional com corporações tradicionais de peso. Assim, empresas como a hegemônica IBM passaram a ter a incômoda concorrência de pequenas e médias empresas, que em pouco tempo se tornavam grandes. Um produto de alta tecnologia, antes oferecido por uma grande companhia, passou a ser fruto da relação de parceria entre várias empresas menores, em busca da racionalização dos recursos e do dinamismo das operações (SAXENIAN, 1994).

Em pouco tempo, os produtos do Vale do Silício dominaram o mercado de TI, levando seu modelo produtivo ao vislumbre de outras regiões ao redor do mundo. Foram muitas as tentativas de repetir o êxito do Vale do Silício, através do investimento em Sistemas Regionais de Inovação compatíveis com o observado no modelo californiano. Entretanto, poucas dessas tentativas deram certo. Segundo Saxenian (1994), o motivo estava além da mera observância das características técnicas das articulações entre indústria, centros de pesquisa e universidades. A cultura era um elemento determinante para a existência de um empreendedorismo contínuo (e movido pela inovação) que alavancasse a economia da região.

O papel do desenvolvimento da TI para os Estados Unidos é tão importante que, segundo Drucker (1987), salvou a economia americana da estagnação prevista pelos padrões cíclicos de obsolescência tecnológica de Kondratieff (SCHUMPETER, 1982, 1983; KONDRATIEFF; DANIELS, 1984), não somente pela mudança do paradigma tecnológico, mas também pela inovação dos arranjos produtivos e pelo empreendedorismo (DRUCKER, 1987), tal qual o modelo encontrado no Vale do Silício. Esses fatores mostraram ao mundo a importância dessa região produtiva muito particular, em um setor de alta competitividade, baseado na inovação e no conhecimento. A era da informação havia chegado, através da aplicação produtiva e social de produtos de uma nova indústria, a indústria de TI. A região que melhor representa essa nova indústria é justamente o Vale de Santa Clara, onde se constituiu o cluster de TI mais importante do mundo.

Entende-se por cluster, segundo Porter (1992), uma concentração geográfica de empresas de determinado setor e os demais agentes correlatos a eles conectados, tais como universidades e fornecedores. Dalsgaard (2001) enxerga os clusters como "redes de firmas e instituições de conhecimento com estruturas em condições comuns. Suas inter-relações criam competências compartilhadas, possibilitando uma produção com relativamente alto valor agregado" (DALSGAARD, 2001,p. 351). 
Bangalore, na Índia, mostrou-se uma região conectada com o empreendedorismo observado no Vale do Silício (VENKATARAMAN, 2004). Como mostra Saxenian (2000), isso não era fruto de uma coincidência, pois uma enorme quantidade de pesquisadores indianos imigrou para trabalhar no Vale do Silício entre as décadas de 1970 e 1980. A esse fenômeno, Saxenian (1994) deu o nome de Brain Drain. Surgiu um momento em que os imigrantes começaram a voltar para a Índia, ora "contaminados" pela cultura do empreendedorismo. Instalaram-se em algumas regiões de destaque tecnológico, em especial na região de Bangalore, iniciando o processo intitulado por Saxenian (2006) como Brain Circulation, no qual os talentos explorados por anos a fio pelas empresas americanas voltaram aos seus lares e constituíram uma revolução na indústria local de TI. Saxenian (2006) nomeia esses novos empreendedores como os "novos argonautas".

Bangalore se tornou um notável cluster de TI, principalmente no que tange ao setor de serviços e desenvolvimento de softwares (KEELEY, 2007; CASTELLS, 1999; PRASHANTHAM, 2008). O sucesso da região pode ser equiparado com outros eventos parecidos ao redor do mundo, tendo como pano de fundo a ação constante do empreendedorismo. A formação de clusters se mostrou colaborativa com o crescimento do setor de TI em nível internacional. Frente ao sucesso observado em regiões da Ásia, tal como Bangalore (Índia), a exemplo do modelo americano do Vale do Silício, outros países passaram a incentivar a formação de clusters tecnológicos. O que mais chama a atenção para o surgimento de um centro de excelência produtiva de TI em Bangalore é a notável distância de sua economia daqueles padrões encontrados nos Estados Unidos. Enquanto o Vale do Silício está localizado no país que detém a maior economia do mundo, representante emblemático do sistema de produção capitalista, a Índia está bem aquém do desenvolvimento financeiro e econômico americano. O sucesso de Bangalore mostra que há mais questões envolvidas na formação de um cluster tecnológico de excelência do que a mera disponibilidade de recursos materiais e uma economia essencialmente capitalista.

O Brasil, considerado um país recém industrializado (FIGUEIREDO, 2005) ou inserido em um contexto de "capitalismo tardio" (CARDOSO DE MELLO, 1982), também mergulhou, desde cedo, na constituição de parques tecnológicos voltados para o desenvolvimento de TI. Inicialmente, com investimento direto do Estado (DANTAS, 2002) na formação de instituições tecnológicas, logo se iniciaram em torno destas os primeiros parques tecnológicos. Um dos mais significativos empreendimentos, em torno do qual se formou um cluster de TI de relevância nacional, foi o antigo Centro de Pesquisas e Desenvolvimento da Telebrás, que após o processo de privatização do setor de 
telecomunicações instituído pelo governo de Fernando Henrique Cardoso passou a constituir a Fundação CPqD (CASTRO, 2005). Localizado na região de Campinas, estado de São Paulo, o referido Centro de Pesquisas conta com a proximidade da Universidade Estadual de Campinas, Unicamp, entre outros centros de excelência de formação de profissionais, da região metropolitana da cidade de São Paulo, a cerca de cem quilômetros dali. Além do $\mathrm{CPqD}$, a região abrigou o Centro de Tecnologia de Informática do Ministério de Ciência e Tecnologia (CTI), hoje Centro de Tecnologia da Informação Ricardo Archer. Grandes empresas de TI se instalaram na região, tais como a HP. Algumas empresas de pequeno porte passaram a emergir, oferecendo suporte e subsídios para as empresas maiores. Lastres e Cassiolato (2001), ainda no início dos anos 1990, observaram que o cluster "compreendia mais de quarenta empresas e empregava aproximadamente 6 mil pessoas" (LASTRES; CASSIOLATO, 2001, p. 142), beneficiada por uma série de vantagens sustentadas pelo investimento governamental. Segundo os autores, ao final dos anos 90, eram menos de trinta empresas localizadas no cluster. De alguma forma, o modelo adotado para consolidação do parque tecnológico não manteve o nível de empreendimentos após a privatização das principais clientes (empresas de telecomunicações) das empresas da região, o que leva a crer que haja falta de consonância do cluster frente às exigências de um padrão de desenvolvimento para manutenção do mesmo.

Outro modelo nacional de cluster tecnológico é o verificado em São Carlos, no mesmo estado de São Paulo, a 144 quilômetros de distância de Campinas. A cidade tornou-se um centro de excelência na formação de profissionais de TI, por abrigar duas universidades de alto padrão, como a Universidade de São Paulo (Campus São Carlos) e a Universidade Federal de São Carlos. A presença das universidades alavancou a vontade política de estabelecimento de um parque tecnológico na região. São Carlos reúne um número menos significativo de empresas de alta tecnologia, mas embora não tenha a mesma expressão da região de Campinas em desenvolvimento de TI, é a sexta cidade nacional em número de publicações científicas (HAYASHI, 2006). Recentemente, a região foi escolhida para a implantação da primeira fábrica de semicondutores da América Latina, uma joint venture entre a empresa norte-americana Symetrix Corporation e o Grupo Encalso-Damha, sob a parceria técnico-científica da Universidade Estadual Paulista, UNESP (ANTUNES, 2008). Isso ressaltará a importância do cluster no contexto nacional.

Apesar dos esforços do governo e de instituições regionais para ampliar a significância dos clusters brasileiros de TI, é notada a distância em excelência dos modelos verificados nos casos do Vale do Silício californiano e, dentro de um contexto de desenvolvimento 
econômico mais próximo, de Bangalore. Enquanto os modelos internacionais apresentados possuem relevância no escopo mundial, os nacionais ainda galgam posições dentro de seu próprio continente, ainda que algumas de suas empresas ganhem projeção internacional.

Em primeiro momento, é perceptível a diferença da importância dada ao pequeno e médio empreendedor nos modelos internacionais e nacionais. Enquanto os modelos internacionais citados se baseiam em arranjos constituídos por uma rede de empreendimentos que partem de pequenos ou médios negócios em TI (alcançando crescimento posterior), os modelos nacionais se baseiam na implantação inicial de grandes empresas, as quais possibilitarão o surgimento de pequenos e médios empreendimentos para suporte de suas atividades. Nesse aspecto, o papel das pequenas e médias empresas é fundamental para a compreensão das relações estabelecidas em clusters de TI, assim como as relações que estas estabelecem com as grandes empresas de seu setor. Segundo Porter (1992), a inovação é um dos componentes indispensáveis para a manutenção de um cluster. Para que haja inovação, é necessário o estabelecimento de uma rede de relações humanas (produtivas ou não) que beneficie o fluxo informacional do interior do cluster. Uma vez estabelecidas estas relações, é possível identificar um Sistema Regional de Inovação. Para que haja manutenção da dinâmica do fluxo informacional e de profissionais no interior do Sistema Regional de Inovação, é necessário um movimento que inicie seu processo, com o estabelecimento de novas empresas, e outros movimentos que dêem continuidade a este, com constante reposição dos agentes de inovação (firmas e profissionais). Para tal, é de extremo valor a existência do empreendedor, que geralmente tem seus primeiros intentos produtivos realizados através da formação de pequenas e médias empresas. Dessa forma, pode-se dizer que as pequenas e médias empresas oxigenam o processo de inovação, por oferecer reposição de seus agentes (STERNBERG, 2007).

O desenvolvimento de pólos regionais de TI deve levar em conta a sustentabilidade do modelo, primando para que não haja relações acentuadas de dependência entre uma empresa de grande porte e as demais de porte inferior localizadas na região, formando uma estrutura que não pode sobreviver à ausência do agente central, líder do sistema (CASTELLS, 1999). Para tal, o cluster deve seguir uma lógica sistêmica de desenvolvimento que priorize não somente o resultado inicial, mas a manutenção deste (MARTINELLI; JOYAL, 2004). Diante disso, o desenvolvimento sistêmico se torna essencial para o desdobramento estrutural do cluster voltado para sua manutenção futura, sob a perspectiva dos resultados.

Este trabalho visa à análise comparativa entre os modelos abordados, em busca de constatações sobre os elementos que potencializam o sucesso na formação de clusters de TI, 
sob diversos aspectos. Uma vez que a relevância da área de TI para as economias integradas no mercado globalizado é ímpar (LOJKINE, 2002), o estudo dos arranjos produtivos dessa nova indústria é imprescindível para a determinação de políticas governamentais de ciência e tecnologia, além de ser importante para a formação de um referencial consistente para os investimentos da iniciativa privada no setor.

\subsection{Justificativa e Relevância}

Em 2007, o governo federal brasileiro anunciou investimentos da ordem de 1,8 bilhões de reais na área de Ciência, Tecnologia e Indústria, da Política Industrial, Tecnológica e de Comércio Exterior (Pitce) para 2008. Desse montante, cerca de 36 milhões de reais foram diretamente destinados ao financiamento do setor de TI, além de outras várias modalidades de investimento que beneficiaram as empresas que o compõem (FIUZA, 2007). Além do interesse governamental em investir no setor de Tecnologia da Informação, outros investimentos partirão da iniciativa privada, interna ou externa, para os Parques Tecnológicos de TI nacionais na próxima década. Esse processo se evidencia na joint-venture internacional para estabelecimento da primeira fábrica de semicondutores da América Latina na região de São Carlos (ANTUNES, 2008), com entrega prevista para 2011. O uso dos recursos disponibilizados, sejam privados ou públicos, de forma efetiva, levando-se em consideração a manutenção da sobrevivência dos empreendimentos gerados após a consolidação dos investimentos, necessita de estudos baseados em referenciais teóricos que abranjam modelos de excelência em arranjos produtivos.

A pesquisa aqui desenvolvida se justifica pela crescente necessidade de referencial teórico acerca do desenvolvimento de clusters de tecnologia da informação nacionais, o qual aborde as falhas e êxitos dos modelos consolidados. Seus resultados poderão orientar a tomada de decisões sobre investimentos públicos e privados no setor brasileiro de TI, tomando como base os resultados da comparação entre os modelos internacionais e nacionais abordados, abrangidos pelo objetivo geral desta pesquisa.

A delimitação do universo de pesquisa compreendendo dois clusters nacionais e dois clusters internacionais foi desenhada por conta da relevância dos mesmos em seus mercados de atuação. O Vale do Silício é a referência de maior importância para a constituição de pólos de alta tecnologia em nível internacional, por conta de ter iniciado o processo de produção regional articulada em TI. Muitas das características encontradas hoje em arranjos produtivos 
regionais, em vários setores industriais, devem-se ao que foi experimentado pelo cluster do Vale de Santa Clara. Dessa forma, possui alta relevância enquanto caso de estudo por fornecer os subsídios históricos primários para a formação de arranjos produtivos, tanto nos aspectos ligados ao empreendedorismo e inovação quanto nas questões ligadas aos resultados sócioeconômicos do estabelecimento de sua excelência de mercado.

O cluster de Bangalore possui importância comparativa em relação aos pólos tecnológicos nacionais, em função de se situar em um país com características de desenvolvimento mais próximas do Brasil do que as encontradas nos Estados Unidos. Além da importância comparativa com o modelo brasileiro de desenvolvimento, Bangalore existe em face de um desdobramento social e econômico do fenômeno do Brain Drain (SAXENIAN, 1994; 2006), o que o torna um bom elemento de comparação com o cluster do Vale do Silício. A análise da formação do cluster de Bangalore pode elucidar lacunas existentes na explicação de fatores oriundos da comparação entre o modelo do Vale de Santa Clara e os modelos brasileiros.

Os clusters nacionais escolhidos para compor esta análise comparativa possuem relevância acentuada na produção e pesquisa de TI brasileira. O cluster de Campinas tem notória expressão em âmbito nacional, com empresas em franco processo de expansão. Alguns dos empreendimentos em TI situados na região de Campinas já se internacionalizaram, garantindo à região o reconhecimento no exterior. Campinas desponta desde a década de 1970 como uma região de referência para a produção científica e industrial nacional em TI. O modelo de desenvolvimento de seu pólo tecnológico é, sem dúvida, o mais apropriado para representar os arranjos produtivos regionais de TI do Brasil, por ter oferecido subsídios referenciais para a organização de pólos semelhantes no resto do país.

A região de São Carlos tem sua inclusão justificada na análise comparativa a que esta pesquisa se destina por conta do recente crescimento de sua importância no cenário nacional de TI, principalmente após a notícia de implantação da primeira fábrica de semicondutores do Brasil em seu território (ANTUNES, 2008). Além da questão industrial latente, o potencial da região em pesquisa científica é ímpar, aglutinando uma gama crescente de talentos na área de TI que atraem, cada vez mais, novos empreendimentos do setor na região.

Das pesquisas nacionais realizadas sobre o desenvolvimento de pólos regionais de Tecnologia da Informação, nenhuma se baseou na comparação entre modelos nacionais e internacionais. Além desse caráter inédito, a pesquisa proposta é inovadora por ensejar uma análise comparativa qualitativa margeada pelos conceitos da teoria dos sistemas aplicada à economia e à administração, no que tange ao desenvolvimento sistêmico das regiões 
elencadas para estudo. Sua relevância se dá não somente pela necessidade observada de um referencial teórico que garanta a efetividade dos recursos empregados em arranjos produtivos de TI, mas também pela oportunidade de estabelecimento de parâmetros conceituais que permitam o desencadeamento de ações que fomentem o desenvolvimento auto-sustentável dos pólos tecnológicos nacionais.

\subsection{Problema de Pesquisa}

A diferença entre os modelos internacionais e nacionais abordados está principalmente no tipo de arranjo interno observado nos clusters produtivos desde seu surgimento. Nos clusters nacionais (em especial no caso estudado de Campinas), é possível observar a tendência de instalação de pequenas e médias empresas que se aproveitam das vantagens de uma região (universidades, centros de pesquisa, disponibilidade de mão-de-obra qualificada, incentivos fiscais, políticas de desenvolvimento tecnológico, etc.), muitas vezes envoltas por uma rede de empresas de grande porte ou instituições de fomento, que lhe servem como fornecedoras de alguns tipos de insumos tecnológicos, de serviços e, principalmente, como geradoras de receita. Já nos clusters internacionais, as redes constituídas são, ao menos em um primeiro momento, principalmente entre pequenas e médias empresas em torno de um produto final, modelo em que ocasionalmente alguns empreendimentos tomam proporções maiores, mas não deixam de competir diretamente com empresas de menor porte. Os modelos internacionais abordados (Vale de Santa Clara e Bangalore) tiveram sucesso econômico maior do que o percebido nos modelos nacionais descritos (Campinas e São Carlos).

Frente a este quadro comparativo, a principal questão que este trabalho busca elucidar é como os arranjos produtivos internos dos clusters de TI e as relações estabelecidas entre seus agentes durante seu desenvolvimento contribuem, ou não, para sua manutenção sistêmica após a consolidação de sua estrutura, e como esses arranjos e relações se dão. Chegando a uma resposta para esta questão, os modelos brasileiros serão avaliados, com base no confronto com os modelos internacionais abordados, levando-se em conta as peculiaridades e características de cada região. 


\subsubsection{Objetivo Geral}

O objetivo geral desse trabalho foi analisar comparativamente os modelos de clusters abordados sob o enfoque das relações estabelecidas entre seus agentes, chegando a conclusões que permitissem a elucidação do problema de pesquisa envolvendo o modelo de desenvolvimento de pólos regionais de tecnologia da informação e sua proximidade com os conceitos de desenvolvimento sistêmico, no âmbito nacional e internacional, principalmente no que se refere à reprodutibilidade de seu modelo operacional, sucesso econômico e manutenção de sua posição de mercado ao longo do tempo.

\subsubsection{Objetivos Específicos}

Os objetivos específicos da pesquisa foram quatro, especialmente orientados para o alcance do que foi determinado no objetivo geral. Foram eles:

1. Análise dos modelos de desenvolvimento dos pólos tecnológicos internacionais propostos, sendo eles o Vale de Santa Clara (Califórnia) e Bangalore (Índia), identificando fatores preponderantes para sua excelência. Esta análise foi fundamentada na vasta bibliografia acadêmica sobre o assunto;

2. Análise das características dos modelos de desenvolvimento dos dois pólos tecnológicos nacionais escolhidos, em Campinas-SP e São Carlos-SP, no que tange às relações de seus agentes internos constituídas com outros agentes do cluster ou com agentes externos, clientes, governos, parceiros e competidores, através da ótica de suas entidades administrativas;

3. Confronto entre as análises dos pólos nacionais e internacionais do universo da pesquisa, tendo elaborado uma nova análise das semelhanças e diferenças, traçada uma perspectiva entre o modo de atuação dos agentes dos mesmos e os dados econômicos obtidos sobre as quatro regiões estudadas;

4. Mapeamento dos sucessos e dos insucessos dos modelos estabelecidos, além dos fatores que condicionam a atuação dos agentes no interior do cluster, suas relações e contribuições para o desenvolvimento econômico e social de suas regiões; 
Os quatro objetivos específicos foram elementos constituintes da compleição do objetivo geral, e sua abordagem metodológica se fundamentou nesse propósito. Entretanto, seus resultados individuais podem ser úteis para outras pesquisas a respeito do tema, uma vez que estes não dependeriam necessariamente da existência de um objetivo geral. Isso significa a ampliação da significância da pesquisa, uma vez que suas subdivisões podem gerar resultados autônomos a ser incorporados como referências em pesquisas futuras, tanto a respeito dos modelos de arranjos produtivos quanto no referente às regiões abordadas. 


\section{REFERENCIAL TEÓRICO}

O referencial teórico que suporta esta pesquisa tem a finalidade de fornecer subsídios para o estabelecimento de conceitos mais claros sobre os assuntos abordados, no intuito de elucidar o problema de pesquisa, além de prover informações sobre as regiões escolhidas para a análise nas etapas posteriores elencadas adiante neste projeto. Este referencial teórico é fruto da primeira etapa da pesquisa, descrita adiante no item 3.3.1. Sua composição se dá pela necessidade de gerar estofo informacional para as análises descritas nos estágios posteriores.

Primeiramente, buscaram-se frente à produção acadêmica disponível definições e conceitos indispensáveis para a análise a que este trabalho se dedica, sendo esses: sistemas regionais de inovação, pensamento sistêmico e arranjo interno de clusters, Tecnologia de Informação, informacionalismo e histórico da formação de clusters de TI. A pesquisa bibliográfica busca também suprir informações acerca dos quatro clusters de TI abordados.

\subsection{Sistemas Regionais de Inovação}

Os sistemas de inovação são estruturas dinâmicas de interação entre agentes de um ambiente que buscam favorecer a emergência de novas técnicas e idéias em um determinado segmento de mercado, sob o escopo da delimitação geográfica. Segundo Asheim e Gertler (2005), são "a infra-estrutura institucional que suporta a inovação dentro da estrutura de produção de uma região" (ASHEIM; GERTLER, 2005, p. 299). Dividem-se em Sistemas Regionais de Inovação (RIS - Regional Innovation Systems) e Sistemas Nacionais de Inovação (NIS - National Innovation Systems). Sua diferença está apoiada não somente no escopo da atuação metodológica, mas também no próprio conceito de auto-sustentabilidade sistêmica.

No que tange ao conceito de sustentabilidade sistêmica, ambos os tipos de sistemas de inovação necessitam de reposição contínua de seus agentes. Este fluxo repositório ajuda a reduzir o risco de dependência estrutural, ou seja, mantém a rede organizada entre agentes de tamanho proporcional aos demais participantes do sistema, tal qual se observa em Boschma (2005). A idéia de um agente central magnificente, de proporções e importância acentuadas frente aos demais componentes do ambiente, vai contra as premissas de manutenção sistêmica 
auto-sustentável, pois se este agente for retirado do modelo, seja qual for o motivo, o sistema como um todo colapsa (STERNBERG, 2007).

Segundo Edquist (2005), um sistema de inovação "compreende todos os determinantes do processo de inovação” (EDQUIST, 2005, p. 182), conceito que inclui fatores econômicos, sociais, políticos, organizacionais e até mesmo culturais, os quais influenciarão diretamente nas relações entre os agentes do ambiente. Apesar de estarem amplamente ligados ao conceito de clusters, os sistemas regionais de inovação estão contidos no conjunto de dispositivos que mantêm a troca de conhecimento tácito e explícito em um determinado espaço. Porter (1992) tem por conceito de cluster uma concentração geográfica de empresas de determinado setor e os demais agentes correlatos a eles conectados, tais como universidades e fornecedores. Diante disso, podemos ter em mente que um sistema de inovação regional se trata do grupo de fatores neste arranjo espacial que possibilitem a emergência de novas tecnologias em produtos, processos e modelos organizacionais.

Entre os determinantes do processo de inovação, tal qual em Edquist (2005), estão os agentes de inovação, ou simplesmente, os profissionais que possibilitarão a emergência de novas tecnologias. Estes profissionais tendem a manter múltiplas relações com o macroambiente, tanto no âmbito regional quanto no supra-regional e internacional. Estas relações podem ser de fluxo de dados ou mesmo de circulação física de profissionais - em consonância com o conceito de brain circulation de Saxenian (2006).

Um sistema regional de inovação possui maior efetividade quando apoiado sobre um cluster, ainda que possa pertencer a um arranjo produtivo regional sem uma setorização bem definida. As relações estabelecidas entre agentes de um cluster costumam ser mais proveitosas do que as estabelecidas entre empresas de diferentes setores situadas em uma mesma região, segundo aponta Gertler (2003), especialmente no que tange aos processos de inovação que têm como pano de fundo a transferência de conhecimento tácito. Se a atuação em um mesmo setor é determinante para o nível das transferências de informações baseadas em conhecimento tácito, a proximidade geográfica entre os agentes é imprescindível para sua ocorrência. Segundo Howells (2002), baseando-se em estudo empírico sobre o assunto, “a transferência de conhecimento tácito é sensível à distância" (HOWELLS, 2002, p. 880). Quanto maior a distância entre os agentes, sejam estes indivíduos ou empresas, menor o nível da transferência de informações baseadas em conhecimento tácito, e derivado disso, menor sinergia informacional e menor competitividade agregada. Os clusters não admitem apenas as relações de proximidade espacial, mas também as intra-organizacionais. 
Conhecimentos tácitos, segundo Miranda (1999), são “o acúmulo de saber prático sobre um determinado assunto, que agrega convicções, crenças, sentimentos, emoções e outros fatores ligados à experiência e à personalidade de quem o detém" (MIRANDA, 1999, p. 287). No mesmo artigo, a definição de conhecimento explícito aponta para "o conjunto de informações já licitadas em algum suporte (livros, documento etc.) e que caracteriza o saber disponível sobre tema específico" (MIRANDA, 1999, p.287). Nesse sentido, é válida a idéia de conhecimento tácito como uma espécie de conhecimento "informal", gerado pela experiência de atuação do agente. Já o conhecimento explícito pode ser encarado como o resultado formalizado das pesquisas e cognições acerca de determinado tema. De igual teor, é possível afirmar que enquanto o conhecimento explícito se legitima pela utilização do suporte físico para o registro das informações que o agregam, o conhecimento tácito apenas se faz presente na memória do agente humano, ou seja, na mente do ator da inovação.

Nos últimas décadas, as relações entre agentes situados em sistemas de inovação de diferentes regiões têm se tornado indispensáveis para a manutenção dos níveis locais de prospecção tecnológica, mudança organizacional ou emergência de novos conceitos. Com a consolidação do quadro de globalização dos mercados nos anos noventa, uma das exigências para a competitividade, seja no âmbito local ou internacional, é a conectividade de agentes regionais com o ambiente externo (CASTELLS, 1999).

Uma vez que as barreiras comerciais vão gradativamente sendo diminuídas pelos intentos dos agentes econômicos com operações globais, a competitividade não mais ocorre em escala nacional, onde a maioria dos concorrentes possui condições parecidas de produção, mas em escala mundial. Em mercados de escala internacional, principalmente no que se trata dos produtos de alta tecnologia, a competição se dá em torno de uma componente principal: a inovação. Basicamente, sai na frente o agente que tiver a inovação como uma constante, seja no âmbito organizacional e processual (garantindo aumento da produtividade e eficiência mercadológica) ou no que se refere à tecnologia dos produtos. Não que em momentos anteriores do sistema capitalista isso não fosse de extrema importância, mas no atual quadro do informacionalismo, termo cunhado por Lojkine (2002) em substituição ao "capitalismo informacional”, chega a determinar a continuidade (ou não) de uma organização.

O informacionalismo é um conceito baseado na premissa de que o capitalismo teve, até os dias atuais, três estágios básicos, sendo estes o mercantilismo (fase em que o comércio teve maior importância dentre os aspectos produtivos), o industrialismo (fase em que a produção de bens de consumo teve destaque no sistema) e, finalmente, o informacionalismo (estágio que se destaca por ter a informação como cerne produtivo do sistema), estágios 
mediados por períodos de transição bastante característicos (LOJKINE, 2002). O informacionalismo inaugurou uma nova fase de transformações tecnológicas, na qual as mudanças paradigmáticas deixaram de ser pontuais para se tornarem graduais (CASTELLS, 1999). Como enunciou Leopoldseder (1999), “desenvolvimentos tecnológicos sempre existiram, o que é novo em nossos tempos é a rápida sucessão de seus saltos quânticos" (LEOPOLDSEDER, 1999, pp. 67-68). A inovação, nos tempos atuais, é o fator crucial para a manutenção dos agentes nos mercados.

Em um Sistema Regional de Inovação, caracterizado pelos agentes de inovação, universidades, centros de pesquisa e desenvolvimento, firmas pré-estabelecidas e demais componentes dos clusters ou da região em que atuam, há um fluxo dinâmico interno muito bem caracterizado. Universidades transferem conhecimentos explícitos e profissionais de alta capacitação para a atuação nas empresas e centros de pesquisa. Os centros de pesquisa fornecem às universidades resultados padronizados de pesquisas avançadas, enriquecendo seu conhecimento explícito - formalmente catalogado. Ainda fornecem serviços de pesquisa e desenvolvimento e conhecimento explícito para as empresas do Sistema Regional de Inovação. As empresas, por sua vez, oferecem emprego aos jovens saídos das universidades quando não se aliam a estas no desenvolvimento de pesquisas e formação de profissionais - e financiam os centros de pesquisa e instituições de desenvolvimento. Em meio a este fluxo estão os profissionais, seres humanos que figuram nesses processos como agentes dotados da capacidade de adquirir conhecimento tácito.

Com a abertura dos mercados locais para o âmbito global, o fluxo dos Sistemas Regionais de Inovação isolados não acompanha as necessidades impostas pelo ambiente competitivo. A taxa de inovação por produto (ou processo) por um dado período em sistemas regionais fechados é muito inferior às taxas verificadas em sistemas regionais abertos, conforme Cooke, Heidenreich e Braczyk (2004). Logo, nada mais natural para manutenção da competitividade do que a formação de conexões entre os agentes dos sistemas regionais e outros agentes localizados no ambiente supra-regional no intuito de estabelecer fluxos informacionais que contribuam para a formação do conhecimento e aumento das possibilidades de inovação.

Em um primeiro passo, essas conexões costumam dar-se entre as universidades e instituições de pesquisa, tal como mostram Fritsch e Schwirten (1999). Segundo os autores, essas instituições costumam oferecer às empresas dos sistemas regionais de inovação informações obtidas pelo contato com outras universidades e institutos de pesquisa e desenvolvimento em outras regiões, localizadas no plano nacional ou internacional. 
Outros tipos de conexões entre agentes de Sistemas Regionais de Inovação e outros agentes pertencentes ao ambiente externo são verificados. Neste ponto deve-se ressaltar que tais conexões se dão com a finalidade de troca de informações com base em conhecimentos explícitos ou tácitos. As conexões que valorizam meramente a transferência de informações, sem estreitamento das relações humanas, são baseadas em conhecimento explícito (ou formalizado) através de seu registro, arquivamento e recuperação. Estas relações são as estabelecidas por convênios de compartilhamento de bases de dados, transferência open source de códigos de programação, serviços de consultoria, entre outros. As conexões que se baseiam na transferência de conhecimento tácito são aquelas onde há presença física do agente humano entre as instituições, ou seja, as modalidades de intercâmbio de recursos humanos.

A preferência de modalidades de conexões entre agentes, que privilegiem a emergência de conhecimento tácito ou explícito na construção de um modelo de gestão para Sistemas Regionais de Inovação, passa pela análise criteriosa de custos e benefícios das ações que favoreçam lidar com cada um dos tipos de conhecimento. $\mathrm{O}$ investimento em ações que privilegiem o conhecimento tácito (caso preponderante do Vale do Silício) agrega valor humano e vantagens competitivas por intensificação das relações entre os profissionais do setor. A relação entre custo e taxa de inovação por ciclo de atuação tende a ser menor no caso dos clusters, favorecendo-se das características desse tipo de arranjo (BATHELD; MALMBERG; MASKELL, 2004). Em compensação, o processo de inovação baseado apenas em conhecimento tácito tende a ser mais lento. Em contrapartida, as conexões que propiciem a transferência extra-regional de conhecimento explícito podem aumentar a taxa de inovações por ciclo de atuação, por importarem conhecimentos já preparados e padronizados. Contudo, o uso desequilibrado das conexões que favoreçam a transferência de conhecimento explícito pode significar um princípio de dependência do Sistema Regional de Inovação frente a sistemas externos.

Uma das máximas de Castells (1999) em relação ao processo de inovação tecnológica no novo capitalismo informacional diz que:

Empresas e nações (...) são os verdadeiros agentes do crescimento econômico. Não buscam tecnologia pela própria tecnologia ou aumento de produtividade para a melhora da humanidade. Comportam-se em um determinado contexto histórico, conforme as regras de um sistema econômico (o capitalismo informacional, como proposto anteriormente), (...) Assim, as empresas estarão motivadas não pela produtividade, e sim pela lucratividade, para a qual a produtividade e a tecnologia 
podem ser meios importantes mas, com certeza, não os únicos. (...) A lucratividade e a competitividade são os verdadeiros determinantes da inovação tecnológica e do crescimento da produtividade. (CASTELLS, 1999, p. 101)

De fato, são as organizações humanas, e não os indivíduos isolados, que acabaram por contribuir com o crescimento econômico através do aumento da lucratividade. Isto vem a reboque do processo de inovação, como peça chave da garantia da competitividade por determinados períodos (cada vez mais breves em nossos dias). Entretanto, a obtenção da inovação não pode ser atingida quando os agentes inovadores se encontram isolados, sem relações entre si. Como visto anteriormente, para que haja mudança ou evolução, são necessárias relações entre grupos e indivíduos, pois o conhecimento só é gerado com base em informações derivadas de outros conhecimentos prévios, adquiridos de experiências de terceiros. Tem-se em mente que não é a "instituição" ou o "grupo", mas os indivíduos, beneficiados pelas formas de se organizarem entre si, que propiciam a mudança e a emergência do novo (SAXENIAN, 2006). A inovação tratará de manter a competitividade entre os grupos, mas somente será gerada através da sinergia (PORTER, 1992).

Os sistemas regionais de inovação, diante dessa dicotomia entre competitividade e cooperação, agem como zonas conceituais de aparente neutralidade competitiva no que tange ao fluxo de informações oriundas do conhecimento tácito. Entretanto, os agentes regionais ainda se valem de dispositivos de contenção de informações estratégicas para que não percam posição frente aos concorrentes de mercado no cluster. Segundo Porter (1992), a coexistência de concorrência e cooperação nos clusters é, até certo nível, absolutamente natural.

Para que haja manutenção da dinâmica do fluxo informacional e de profissionais no interior do sistema regional de inovação, é necessário um movimento que inicie seu processo, com o estabelecimento de novas empresas, e outros movimentos que dêem continuidade a este, com constante reposição dos agentes de inovação (firmas e profissionais). Para tal, é de extremo valor a existência do empreendedor.

As empresas de Tecnologia da Informação são consideradas por autores como Edquist (2005) e Saxenian (1994) como Empresas Baseadas em Conhecimento (KBF, do inglês Knowledge-Based Firms). As KBFs são empresas envolvidas com tecnologia de ponta ou especialistas em processos de alto nível cognitivo. Todas as KBFs, tanto as já estabelecidas (em clusters ou não) quanto as recém-iniciadas, necessitam da inovação para garantia de competitividade em mercados abertos. Para tal, o empreendedorismo se qualifica como instrumento de evolução da parametrização organizacional e tecnológica, pois as novas 
empresas trazem consigo novos métodos oriundos de desenvolvimento realizado anteriormente pelos agentes de inovação. Segundo Koschatzky (2001), as novas KBFs acabam por definir quais das inovações geradas pelos Sistemas Regionais de Inovação são passíveis de serem comercializadas, pois optam a partir de sua concepção pela utilização daquelas descobertas que mais favoreçam sua atuação no mercado. As KBFs préestabelecidas tendem a seguir os movimentos nas novas empresas, no sentido de se manterem atualizadas frente ao mercado, prezando pela competitividade. Isso aponta para a idéia de que nem todo o novo conhecimento gerado será aproveitado. Parte da inovação é sumariamente descartada, por ter emergido em um momento tardio ou por simplesmente não ser compatível com a realidade de produção ou absorção dos mercados. Esse processo é denominado "filtro de conhecimento" (KOSCHATZKY, 2001).

Outro fator fundamental do empreendedorismo é a realocação de profissionais no contexto produtivo de um cluster ou região dotada de um Sistema de Inovação. Empregados passam a ser empregadores, trazendo para o comando das companhias um poder decisório atrelado ao conhecimento tácito adquirido no exercício de outras funções no setor. Saxenian (1994) mostra que o levante de empreendedorismo que caracterizou a emergência do Vale do Silício (um processo contínuo que se mantém há mais de trinta anos) foi responsável por boa parte dos processos inovadores gerados na região. A grande maioria dos empreendedores do Vale de Santa Clara era composta por antigos funcionários de empresas do setor de informática ou telecomunicações, ou então pesquisadores dissidentes das universidades e institutos de pesquisa e desenvolvimento da região (e em um segundo momento, do mundo todo). Estes empreendedores, atuando como agentes de inovação no Sistema Regional, contribuíram para o desenvolvimento de conhecimentos específicos daquela região e, após isso, ajudaram a inseri-los no processo de comercialização - dessa vez como chairmen de seus próprios negócios.

O empreendedorismo pode ser visto como um método prático de difusão de conhecimento, em vários níveis (SAXENIAN, 1994). Primeiramente, com a inclusão de novos produtos e processos no mercado, há a circulação de novas informações entre os agentes de inovação dos Sistemas Regionais, ou seja, o simples fato de se comercializar um produto com aspectos inovadores faz com que haja um movimento de absorção das informações referentes àquele produto pelos demais agentes do sistema. Esse processo de absorção gera uma contrapartida que é a resposta dos demais produtores do mercado às diferenças competitivas dos novos produtos. Essa contrapartida significa investimento em inovação. Outro fator de difusão de conhecimento é a migração de conhecimento tácito 
adquirido em empresas e instituições anteriormente ocupadas pelo empreendedor para uma nova estrutura de produção. Esse processo pode ser realizado tanto no nível intra-regional (quando o empreendedor se origina de outras empresas no mesmo Sistema Regional de Inovação) ou mesmo internacional (quando o empreendedor vem de outros Sistemas Nacionais de Inovação) (STERNBERG, 2007).

As diferenças entre conhecimento tácito e explícito em Sistemas Regionais de Inovação se dão desde as formas de apresentação de cada tipo até os resultados de sua inserção no fluxo informacional regional. O conhecimento tácito, por se apoiar na figura do indivíduo ou do profissional, aproxima-se de conceitos como "capital humano" e "potencial cognitivo", especialmente no que tange ao implemento das potencialidades de inovação em determinados setores (MIRANDA, 1999). Há uma relação de equilíbrio a ser observada entre conhecimento tácito e explícito nos Sistemas Regionais de Inovação, tendo visto que o conhecimento tácito aplicado aos produtos ou processos passa pela codificação de informações, gerando conhecimento explícito. A emergência de inovações vem da congruência entre conhecimento explícito (baseado em registros de pesquisas anteriores) e conhecimento tácito (oriundo da experiência dos agentes), sob as proporções particulares de cada setor ou mesmo cluster.

Para manutenção da auto-sustentabilidade econômica em um cluster, tem-se por consenso entre os autores Boshma (2005) e Sternberg (2007) que se deve manter certa proporcionalidade de tamanho, influência e importância entre os agentes internos, para que não haja a possibilidade de dependência de todo o Sistema Regional de Inovação em torno de um ator principal. A ocorrência de empreendedores é de sumária importância para manter este equilíbrio interno do sistema, não somente pelo oferecimento de mudanças estruturais na rede interna de cooperação e competição como pela veiculação de novas descobertas nos mercados, puxando as demais empresas do setor rumo à inovação competitiva. Ainda que o motivo principal da inovação seja a competição, tanto no escopo regional quanto no internacional, esta somente ocorrerá sob a constante transferência de conhecimentos com o ambiente interno e externo de um Sistema Regional de Inovação. Dessa forma, a inovação se caracteriza em meio a uma dicotomia entre competição e cooperação, que remete ao conceito inicial de clusters (PORTER, 1992).

Entre as transferências de conhecimento tácito realizadas pelas conexões interregionais dos Sistemas de Inovação estão as modalidades tipificadas pelos estudos do Vale do Silício, tais como o Brain Drain e o Brain Circulation (SAXENIAN, 1994, 2006), o último como resposta ao primeiro. Em ambos os casos, o fator diferencial que impulsiona a absorção 
de conhecimentos de uma região em outra é o próprio profissional. No caso das empresas baseadas em conhecimento, o indivíduo - enquanto mecanismo cognitivo e agente de inovação - possui importância ainda mais acentuada, por tratar-se do veículo e (ao mesmo tempo) instrumento da mudança de produtos, processos e arranjos. As conexões estabelecidas pelos agentes de inovação de um Sistema Regional de Inovação, tanto no âmbito interno quanto no internacional, serão importantes para a manutenção da competitividade de toda a região em diferentes mercados, por determinar sua capacidade de inovação. Tão importante quanto as relações estabelecidas entre os agentes situados em diferentes instituições de um mesmo Sistema Regional de Inovação são aquelas que eles realizam com o ambiente supraregional e internacional, ao passo de que podem determinar a continuidade de sua existência no mercado.

\subsection{Pensamento Sistêmico Aplicado ao Conceito de Cluster}

O pensamento sistêmico possui por essência a prática de "ver os inter-relacionamentos subjacentes, em vez de cadeias lineares de causa e efeito, e ver os processos de mudança, em vez de simples fotos instantâneas" (MATOS; MATOS; ALMEIDA, 2007, p. 82). Tem-se disso a idéia de que o pensamento sistêmico foca o todo dinâmico, levando em conta o desdobramento das interações entre as partes.

Aplicar a teoria dos sistemas ao conceito de aglomeração de agentes produtivos de um único setor, localizada em uma região específica é algo que não imprime dificuldades, uma vez que a própria definição de cluster passa pela idéia de cadeia de relações em rede. Todo tipo de encadeamento processual de relações pode ser visto como processo sistêmico, e pode assim ser interpretado de acordo com a teoria dos sistemas.

O cluster é, conforme visto por Porter (1992), um sistema produtivo aberto que se utiliza da sinergia entre diferentes agentes para compor um diferencial produtivo que eleva o escopo das vantagens competitivas do âmbito organizacional para o âmbito regional. As vantagens regionais analisadas por Saxenian (1994), ao verificar o excelente desempenho do modelo de arranjo produtivo do Vale do Silício frente ao consolidado na Rota 128, estão em conformidade com a tendência observada por Dantas (2002) para o setor de TI, ainda que em um escopo diferenciado da pesquisa de Saxenian (1994). Ambientes com níveis "controlados" de competição são mais interessantes, do ponto de vista concorrencial, para as empresas de setores que dependam de constante inovação tecnológica, por conta dos altos investimentos 
necessários em pesquisa e desenvolvimento de novos produtos. A competição controlada pode ser entendida como a ocorrência de competição entre agentes em determinados segmentos de mercado, sob produtos finalizados, mas de cooperação no âmbito produtivo ou mesmo em outros segmentos de mercado.

Um modelo exemplar de competição sinérgica é o estabelecido em cadeias produtivas de empresas baseadas em conhecimento, tais como as de TI. Estas cadeias produtivas são geradas sobre relações de interdependência dadas pela posse de conhecimentos técnicos por parte das fornecedoras, que por sua vez necessitam de projetos que articulem seus produtos com outros componentes (fornecidos pelos demais agentes da cadeia produtiva) para oferecimento de um produto final por um agente no topo da cadeia produtiva, que se torna viável para o mercado. A competição, nesse caso, se dá na disputa pela posse de conhecimentos que possibilitem a melhoria técnica dos insumos tecnológicos para constituição de produtos finais. Se o recebedor de insumos no nível hierárquico imediatamente superior da cadeia produtiva fizer descobertas que levem a maiores vantagens produtivas em relação aos produtos que adquire de um fornecedor, provavelmente passará a adotar outra metodologia de composição de seu produto, substituindo o insumo tecnológico outrora adquirido no nível imediatamente inferior da cadeia produtiva por uma variante com tecnologia própria, reduzindo seu grau de dependência das instâncias inferiores. Entretanto, a substituição de insumos tecnológicos não é tão simples, pois demanda altos investimentos em pesquisa e desenvolvimento e a consolidação da capacidade de produção do insumo a ser substituído, o que pode desviar o foco original da empresa.

A oposição semântica entre competição e sinergia não se mantém frente ao que é observado nos arranjos produtivos de tecnologia. De fato, os dois termos passam a se completar, num jogo de causa e conseqüência que remete ao conceito de sustentabilidade do modelo econômico. Para que haja inovação, é necessário que haja estímulos organizacionais que condicionem e orientem as ações de pesquisa e desenvolvimento de novos produtos, processos e estruturas (CARLIN; SCHAFFER; SEABRIGHT, 2004). Este estímulo é dado, em grande parte, pela competição (PORTER, 1998). A competição estimula o processo de inovação, mas este - na grande maioria dos casos - demanda investimentos vultosos em novos padrões tecnológicos a serem agregados ao contexto produtivo. Os investimentos se valem de diversos tipos de recursos, não somente o financeiro, mas em ambientes de alta dinâmica competitiva, o recurso mais importante é o tempo. Apesar das exceções, dadas por características culturais (atreladas à aceitação social da mudança tecnológica), em geral a obtenção de inovação em tempo menor que o dos concorrentes se desdobrará em vantagem 
competitiva. Para que isso ocorra, é necessária a concentração de recursos (humanos, financeiros, tecnológicos, estruturais, etc) em uma mesma direção, ou seja, rumo à prospecção tecnológica (pesquisa e desenvolvimento), para que se possa realizar mais em menos tempo. É nesse contexto que a sinergia entre diferentes agentes encontra espaço. Se a competição demanda "criar mais" (ou gerar inovação) em menos tempo, a colaboração é um dos dispositivos para a orientação de uma soma maior de recursos para o mesmo fim. Economia de tempo, em cenários competitivos, na maioria das vezes tem um peso maior do que a economia dos outros recursos envolvidos.

A agregação de recursos externos através do estabelecimento de parcerias pode significar saltos cronológicos para o desenvolvimento de produtos, por importar elementos prontos para esquemas produtivos que ainda precisavam desenvolvê-los. Significa dizer que há, mais uma vez, economia de tempo em pesquisa e desenvolvimento, através da aquisição de tecnologia já existente, que demandou tempo para sua constituição no passado. Isso remete ao conceito de trabalho morto de Marx (2008), sob a ótica da apropriação colaborativa do trabalho realizado em momentos anteriores e sua adequação a uma nova lógica de produtos, processos e estruturas, típica do contexto atual.

O sucesso dos modelos consolidados de clusters de tecnologia de informação, principalmente os modelos do Vale de Santa Clara e Bangalore, é oriundo do tipo de integração entre empresas, originado principalmente na Califórnia a partir dos anos 70. Cada agente se encarrega de desenvolver - de forma contínua - as especificidades que inicialmente se incumbem na cadeia produtiva, de forma a aprimorar a sua especialidade técnica (Saxenian, 1994), inovando dentro de um escopo limitado, mas de forma constante. Assim, a cooperação tende a ser cada vez mais efetiva na cadeia produtiva, impulsionada por um nível de competição que, ao invés de desagregar, eleva a necessidade e a busca por inovação.

Segundo Powell (1990), as redes produtivas possuem características próprias, diferentes daquelas observadas nas relações de mercado e de hierarquia, pois se pautam pela dinâmica de acesso rápido a fatores que impulsionem a obtenção de vantagem competitiva através da cooperação. Esse argumento se articula com as premissas do estabelecimento de redes produtivas elencadas por Amato Neto (1995) como fatores de indução do processo de desintegração vertical das empresas. Dessa forma, o estabelecimento de redes produtivas favorece a redução de custos operacionais de uma empresa, pela transferência destes aos parceiros, reduzindo o escopo de atuação dos agentes iniciais sobre o processo como um todo.

Diante da formação de redes produtivas, ainda que sua dinâmica exista sob as premissas da teoria dos sistemas, pode-se observar que sua estrutura tende a variar de acordo 
com a tipologia de redes, acompanhando as relações desenvolvidas entre os agentes. Segundo Guerrini (2005), há uma extensa gama de classificações para as redes de empresas, uma vez que sua configuração varia de acordo com seu grau de formalidade, tipos de processos desempenhados, número de agentes e grau de comprometimento com os resultados e riscos assumidos.

As redes cooperativas em arranjos produtivos e clusters de tecnologia podem assumir diversas formas, tendo sua complexidade estrutural dada pelo número de agentes e tipo de relações envolvidas no processo produtivo. Entretanto, é possível categorizá-las em dois grandes grupos, sob uma taxonomia típica da Geografia e da Ecologia: multinucleados e mononucleados. A importação de uma taxonomia inicialmente proposta em outras áreas do conhecimento vem a reboque da necessidade, até então não atendida pela literatura das áreas de Administração ou Economia, de análises sobre a dependência estrutural interna dos arranjos produtivos setoriais.

\subsubsection{Clusters Mononucleados}

Os clusters mononucleados são aqueles que possuem um agente central que mobiliza a atividade dos outros agentes ou grupos de agentes envolvidos no processo produtivo. $\mathrm{O}$ núcleo sistêmico, desempenhado por um elemento de importância singular para o cluster, agrega uma quantidade superior de recursos e participação de mercado, condicionando os demais agentes conectados a este no processo produtivo a servirem como fornecedores de insumos e recursos específicos, muitas vezes sob regimes de exclusividade. O núcleo funciona como o eixo político/normativo do arranjo produtivo, estabelecendo-se como elemento de maior importância no contexto do cluster.

Em clusters multinucleados, observa-se que não há comprometimento com todas as principais premissas do estabelecimento de redes produtivas, sendo que é mais comum enquadrar suas relações sob a tipologia de Outsourcing ou Terceirização (GUERRINI, 2005). Isso significa dizer que nos clusters mononucleados é comum encontrar regras específicas de atuação para os fornecedores, periféricos ao núcleo, sendo o contratante, organização no núcleo do sistema, responsável pelo estabelecimento dos parâmetros de atuação dos demais agentes. Significa dizer que o sistema depende, intensamente, da atividade desse agente central, que mobiliza as ações das outras organizações envolvidas. Nos modelos produtivos 
mononucleados, as empresas centrais são grandes organizações, geralmente multinacionais, grandes institutos de pesquisa ou organizações nacionais com grande relevância de mercado.

O surgimento dos arranjos produtivos mononucleados pode ser explicado, historicamente, pela necessidade que alguns nichos de mercado possuem de acumulação de capital para financiamento de pesquisas e desenvolvimento de meios de produção adequados para a viabilização da atuação de seus agentes. Segundo Dantas (2002), áreas como as telecomunicações, por exemplo, demandam investimentos altíssimos para implantação de redes e desenvolvimento de tecnologia compatível com a demanda do mercado. Essa é uma verdade presente não somente na moderna indústria de alta tecnologia, mas em outras que contribuíram historicamente para o desenvolvimento do sistema capitalista, talvez tendo encontrado seu modelo mais emblemático no desenvolvimento das estradas de ferro no século XIX (HADLEY, 2009). A necessidade de concentração de capital para atuar em determinados segmentos, como o de siderurgia, base de uma indústria pesada que possibilitasse o surgimento das estradas de ferro, fez com que o modelo corporativo emergisse como solução para o ganho de dimensão necessário para concentrar os recursos demandados. A idéia da corporação está, enquanto entidade central de condução produtiva, diretamente ligada à idéia de concentração da posse dos meios de produção ou dos canais de acesso ao mercado.

De fato, é possível verificar que o surgimento da grande corporação capitalista remonta ao período em que o pensamento de integração estava em foco no mundo ocidental. Enquanto na Europa e nos Estados Unidos a figura do Estado Nacional voltava a ter o seu valor, representado pela concentração da estrutura decisória política (HOBSBAWN, 2006), o capitalismo também chegava ao seu estágio industrial sob a premissa da concentração, e não da distribuição. A centralização do poder decisório é uma das características do período compreendido entre o início do capitalismo industrial e a década de 1930.

Modelos produtivos mononucleados tendem a possuir um número menor de relações internas entre os agentes, ao menos quando comparado com os modelos multinucleados (geralmente formado por redes multidirecionais). Essas relações se dão em mão única, ou seja, do menor para o maior, conforme mostrado na Figura 1.

Em países como Brasil, assim como outros em franca fase de desenvolvimento, a exemplo de momentos anteriores das economias hoje consideradas desenvolvidas, não é rara a intervenção de grandes agentes, como o Estado, no investimento de redes produtivas de setores ligados à tecnologia. Algumas dessas intervenções acabam por gerar estruturas mononucleadas, por instituir um agente central de fomento ao desenvolvimento dos demais agentes da região. 
Figura 1

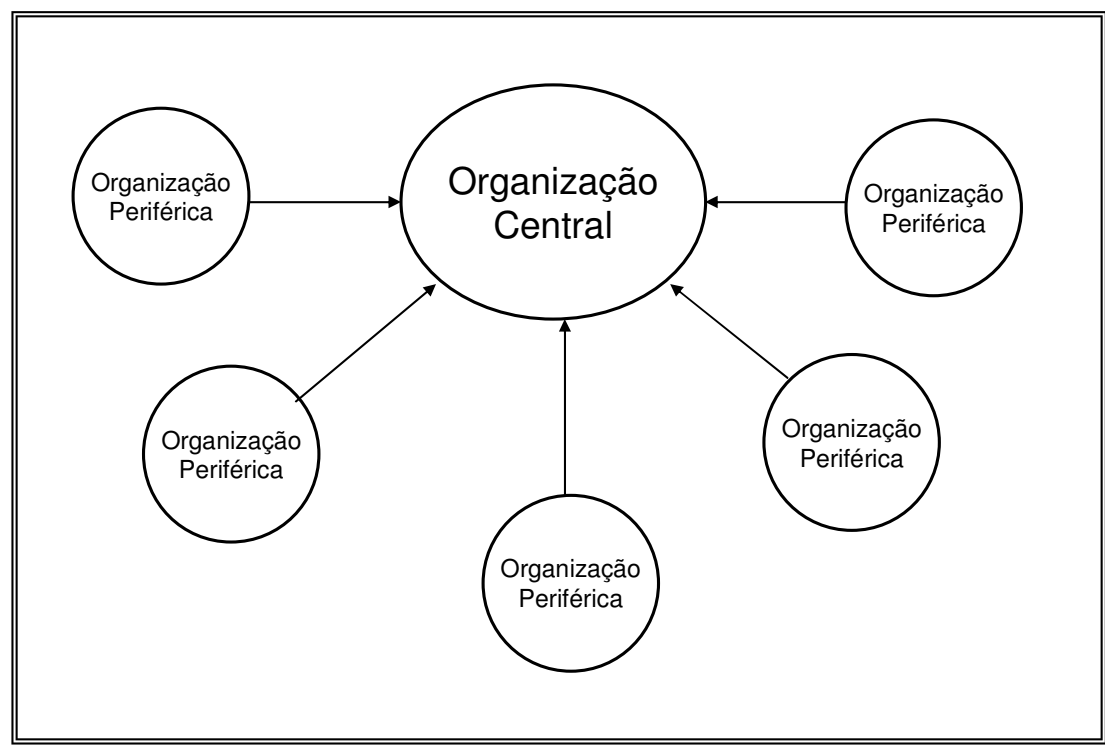

Representação Geral de Modelo Produtivo Mononucleado

Fonte: Autor.

Muitos clusters, tais como alguns casos brasileiros, formaram-se em torno de grandes empresas já instaladas em suas regiões, numa rede de interações que privilegia a posição dos agentes centrais do sistema produtivo regional, claramente estruturada sob a forma mononuclear, em que as empresas menores acabam dependentes das maiores que, lideram o cenário produtivo, desequilibrando as relações existentes.

Os arranjos produtivos mononucleados podem surgir de estruturas do tipo topdown, em que estágios custosos da produção são repassados para empresas periféricas enquanto as organizações centrais se ocupam da inovação tecnológica, do marketing e da logística de distribuição e relação com fornecedores (CASAROTTO FILHO; PIRES, 1999). Esse tipo de arranjo surgiu pela incapacidade de algumas corporações administrarem eficientemente todas as etapas de conclusão de um produto ou projeto, mas não descentralizou o poder decisório. Estando as decisões principais do arranjo produtivo condicionadas aos detentores do knowhow tecnológico e de mercado, ainda há forte dependência do modelo para um agente central.

\subsubsection{Clusters Multinucleados}

As redes multidirecionais tendem a se estabelecer em arranjos produtivos regidos por diferentes núcleos de relacionamento com o mercado. Nesse tipo de rede, os relacionamentos 
entre os agentes participantes estabelecem arranjos de diferentes formas, com finalidades distintas. Por não haver concentração de importância sobre um único agente, ou seja, a evidência de um núcleo decisório distinto, e estando o poder político/normativo diluído na rede, ocorre a constatação de vários núcleos de decisão, determinando-se uma estrutura multinucleada. Sua representação gráfica genérica é dada pela Figura 2.

O impulso nas relações entre organizações que determinou o estabelecimento das primeiras estruturas produtivas multinucleadas foi dado, a partir da década de 1930, em função da necessidade de adequação ao ritmo de mudanças tecnológicas em diversos setores. Para Schiller (2008), a inovação repousa sobre a necessidade de relações mais estreitas entre os agentes de um segmento, estabelecendo sistemas de inovação de alta efetividade. Diante da necessidade de mudança trazida pela competição entre players, "esses sistemas baseiam seu desenvolvimento em laços estreitos multidirecionais e complexos de interdependência entre atores que acarretam a constituição de redes de cooperação" (SCHILLER, 2008, p. 111).

\section{Figura 2}

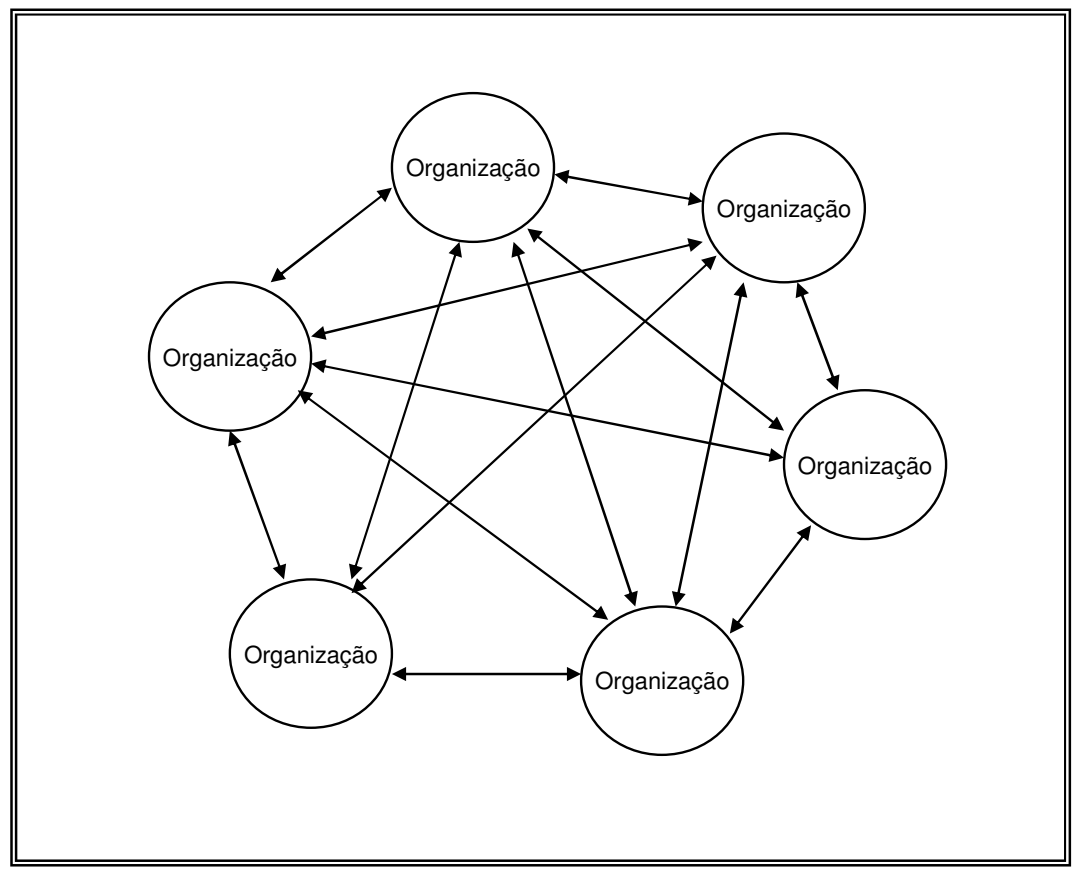

Representação Geral de Modelo Produtivo Multinucleado

Fonte: Autor.

Em modelos multinucleados, há notadamente o surgimento de uma maior quantidade de organizações concorrentes (SAXENIAN, 1994), por conta da fragmentação do mercado. Em mercados onde há maior parcela de participação em poder de um agente central, este 
passa a se utilizar da capacidade de escala para redução de custos, tomada do mercado e diminuição do potencial de operação dos concorrentes diretos e indiretos. Já nos modelos multinucleados, isso tende a ocorrer em intensidade muito menor, entre outras diferenças.

A intensidade das relações entre os membros de redes multinucleadas pode variar de acordo com seu papel frente à produção. Em uma rede produtiva complexa, algumas atividades de suporte, tais como serviços ligados a projetos e consultorias de diversas espécies, podem ser encontrados em todos os níveis da cadeia produtiva, sendo atividades estritamente ligadas ao fluxo de informações e de assessoria ao poder decisório. Uma vez que o poder decisório não é centralizado, a ocorrência desse tipo de atividade tende a ocorrer em maior número, ainda que seja possível a existência de unidades voltadas a suporte informacional que atendam às necessidades de vários agentes da rede ao mesmo tempo.

\subsubsection{Complexidade das relações em um cluster}

Um cluster, pela definição de Porter (1992), deve conter, primordialmente, relações entre seus agentes, integrados de forma sinérgica. Todavia, nem sempre encontraremos todos os integrantes de um cluster integrados em uma única rede produtiva. Dessa forma, pode haver diferentes redes de relações em um único cluster, e até mesmo a integração com redes produtivas que escapam ao escopo territorial delimitado pelo caráter regional do conceito de cluster. A complexidade de formação de redes de cooperação produtiva em um arranjo produtivo de escopo regional ou local é a mesma encontrada na formação das relações em sociedades complexas. Assim como no estudo das relações entre entidades e indivíduos em sociedades complexas (SAWYER, 2005), o estudo das relações entre empresas tem diferentes estruturas de integração, que se conectam de maneira recursiva, com múltiplas referências entre as diferentes redes em diferentes níveis e instâncias. Se em sociedades complexas as redes se mantêm por relações de afinidade (VELHO, 1994) ou em busca da satisfação nas necessidades físicas ou subjetivas dos indivíduos (LINTON, 1952), nas estruturas de relações delineadas por empresas, a manutenção sistêmica se dá pela busca do lucro - que em sua origem corrobora com a idéia de satisfação dos desejos dos indivíduos por trás das organizações.

Assim como ocorre com os indivíduos, as empresas possuem objetivos diferentes, e padrões diferenciados de atuação que se estabelecem em função de sua trajetória de relações com o meio social em que se situa. Esse comportamento se repete no interior das 
aglomerações de organizações de um mesmo segmento, especialmente no que tange ao estabelecimento de relações com outras empresas. Cada organização deverá avaliar sob perspectivas particulares as questões atreladas ao estabelecimento de relações com outros atores do mercado, seja em escopo regional ou global. O processo decisório que rege o estabelecimento de tais relações também se pauta pela análise de uma rede complexa de relações entre expectativas e o contexto atual. Dessa forma, qualquer abstração teórica das relações estabelecidas em um arranjo produtivo estará fadada à redução, uma vez que a gama de complexidade envolta sob o surgimento das relações entre organizações advém desde a tomada das primeiras decisões acerca de estabelecer um vínculo de cooperação até o modelo final estabelecido.

Não bastasse a complexidade da caracterização da formação de arranjos produtivos em clusters, há a possibilidade de estabelecimento de redes em diferentes níveis. Empresas que não possuem nenhum tipo de relação produtiva direta podem estar conectadas por um programa de fomento de projetos, ou mesmo por relações não formais entre seus agentes internos. Dessa forma, há dificuldade para identificação do tipo de relação estabelecida entre empresas que compartilham do mesmo setor e espaço geográfico (cluster) e, de certa forma, da mesma cultura regional e possibilidades de acesso ao mercado. Estarão ligadas por elementos subjetivos ainda que não possuam vínculos declarados de cooperação.

Esse tipo de relação pode ser observado até mesmo entre empresas concorrentes (SAXENIAN, 1994). Empresas que prospectam inovações para produtos que concorram no mercado acabam gerando uma rede de cooperação a sua volta (vínculos com universidades e institutos de pesquisa, relações com agências de fomento, etc.) que pode estar sendo compartilhada por ambas.

A discussão sobre se há ou não uma relação entre empresas alojadas em um cluster deve ficar então apenas no âmbito daquilo que pode ser considerado formalizado, notório ou explícito, pois quando observadas as possibilidades de relações indiretas, é possível dizer que todas estão de certa forma ligadas, principalmente por aquilo que as orienta a se estabelecerem próximas uma das outras, seja pelas vantagens logísticas ou pelas facilidades que a região oferece para seu setor. Enfim, o estabelecimento de critérios que condicionem um cluster como mononucleado ou multinucleado passa pela observância de que ainda que não haja relações evidentes entre todos os membros de um cluster, é possível que a própria coabitação de um espaço geográfico comum contribua para que as ações de um exerçam influências sobre as ações de outro. Dessa forma, ainda que indiretamente, há a observância da existência de uma rede entre os agentes do cluster, ainda que esta não seja explicitamente 
identificada. Contudo, a temática da configuração não repousa somente na existência de relações, mas também na dimensão da importância que um agente possui frente aos outros ocupantes do cluster.

As diferentes formas de relacionamento entre organizações em arranjos produtivos deram origem a uma terminologia própria do estabelecimento de relações produtivas determinadas pela área de atividade e territorialidade. A descrição e diferenciação dos termos mais relevantes para compreensão dos tipos de estruturas existentes são abordadas no tópico 2.3.

\subsubsection{O Conceito de Desenvolvimento Sistêmico}

A teoria dos sistemas aplicada à administração e economia cogita a possibilidade de um padrão de desenvolvimento coerente com a idéia de continuidade e sustentabilidade do modelo produtivo ao longo dos tempos. Nos últimos anos, em especial no Brasil, os teóricos de sistemas têm procurado uma diferenciação semântica entre os termos desenvolvimento sustentável e desenvolvimento sistêmico, tendo em vista que os trabalhos acadêmicos associados à sustentabilidade de modelos produtivos passaram a enfocar apenas as questões relativas aos choques ambientais do desenvolvimento das sociedades humanas, além das alternativas para reduzi-los ou não amplia-los. Outras facetas do desenvolvimento sustentável têm sido negligenciadas, como o desenvolvimento econômico-social, político e educacional. Para recuperar o conceito original de sustentabilidade, propôs-se na literatura a utilização de um novo termo que represente a idéia de capacidade de reprodução de modelos produtivos ao longo do tempo sem riscos de pane sistêmica por escassez de recursos ou rupturas de relações relevantes, denominado desenvolvimento sistêmico.

Segundo Giancola e Hutchison (2005), "a noção de desenvolvimento sistêmico sugere a idéia de componentes discretos de um sistema começando a trabalharem juntos como um todo refinado" (GIANCOLA; HUTCHISON, 2005,p. 63). Significa dizer que sob as premissas do desenvolvimento sistêmico, a expansão do modelo se dá de forma sinérgica, com as partes envolvidas alinhadas em função de um objetivo maior, que é o de manutenção sistêmica. Esse alinhamento pode não se dar de forma declarada, mas percebido nos elementos que elencam a cultura organizacional que induz as partes a trabalharem de forma articulada, beneficiando o todo. 
O tipo de desenvolvimento delimitado sob a ótica sistêmica é aquele que articula a melhoria de vida das pessoas envolvidas nos processos produtivos e dos indivíduos direta ou indiretamente conectados ao contexto de suas atividades, seja no âmbito social, econômico, educacional ou ambiental (MARTINELLI; JOYAL, 2004). Dessa forma, as organizações que operam visando o desenvolvimento sistêmico o fazem sob premissas que visam à obtenção de condições melhores de existência a cada ciclo operacional. Qualquer um dos fatores envolvidos em sua existência que acabe por comprometer a reprodutibilidade das melhorias alcançadas ou seu aprimoramento pode significar o rompimento do desenvolvimento sistêmico.

Os modelos gerados sob a lógica do desenvolvimento sistêmico devem, para que haja manutenção de sua existência, ser flexíveis no que toca à sua estrutura de relações. Se uma das entidades conectadas ao todo sofrer um colapso natural - tendo em mente que nem sempre é possível prolongar o ciclo de vida organizacional - deve ser possível o rearranjo interno para a manutenção das funcionalidades que permitam a reprodutibilidade do sistema ao longo do tempo. Isso remonta à idéia de adaptação a novos contextos, o que inclui entre as premissas do desenvolvimento sistêmico a preservação da capacidade de adaptação dos modelos. Segundo Honadle (1999), “a capacidade de adaptação requer capacidade de pesquisa e monitoramento. O desenvolvimento sistêmico será intensivo em informação e envolverá a criação de novos mecanismos de mensuração dos sucessos” (HONADLE, 1999, p. 23).

A afirmação de Honadle (1999) corrobora com a instituição da capacidade de adaptação entre os elementos típicos do conceito de desenvolvimento sistêmico e abre caminho para a questão da mudança paradigmática em torno dos mecanismos de aferição de resultados. As metodologias usuais de mensuração de resultados, como a tomada do Produto Interno Bruto em Macroeconomia, podem não refletir os resultados integrados sob a ótica do desenvolvimento sistêmico. Vários são os intentos atuais em direção do desenvolvimento de novas formas de mensurar a atividade produtiva humana em diversos setores, assim como a intensidade de suas relações e impactos em seus contextos de atuação. As tentativas em melhorar indicadores como o Índice de Desenvolvimento Humano (SEN, 1989) são exemplos claros de movimentos a favor de técnicas mais abrangentes de avaliar as ações desempenhadas em sociedade. A utilização de técnicas soft, como a Soft Systems Methodology (CHECKLAND, 1981; 1999), para diagnóstico e avaliação dos modelos observados sob a lógica do desenvolvimento sistêmico é necessária para a interpretação das relações existentes entre os elementos envolvidos no sistema. 
No âmbito da prospecção e disseminação de informações presente na afirmação de Honadle (1999), encontra-se a efetividade comunicacional entre as partes envolvidas nos processos sistêmicos. A comunicação deve ser reflexiva, ou seja, exaurir os sentidos do que é percebido no ambiente em busca de um sentido coletivo mais próximo do que é percebido individualmente (ARCHER, 2003). A abrangência de sentidos no ato comunicativo deve ser colocado em pauta sempre que diversas Weltanschauungen (visões de mundo) coexistem, para que se possa extrair algum entendimento das ações coordenadas e relações estabelecidas entre partes de um mesmo sistema (MIRANDA, 2005).

Para que haja condições de adaptabilidade sistêmica, é preciso que nenhuma das partes seja insubstituível, a ponto de seu colapso significar também o colapso de todo o sistema. Outro elemento importante, talvez um dos mais expressivos, sob o ponto de vista do desenvolvimento sistêmico é a relativa equidade entre as partes. A equidade garante o equilíbrio sistêmico, que favorece a adaptabilidade frente às mudanças.

O conceito de desenvolvimento sistêmico está ainda em fase de transformação, assim como deve ser o elemento que o termo representa. Categoriza um tipo específico de desenvolvimento, no qual devem ser observados diversos fatores que permitam a reprodutibilidade do sistema no decorrer do tempo, sem rígida manutenção de estruturas. Flexibilidade, equidade e relações entre as partes que permitam fluxo contínuo de informações são alguns dos elementos que caracterizam o conceito.

\subsection{Taxonomia dos Arranjos Produtivos: a busca pela diferenciação conceitual entre cluster e APL}

Os arranjos produtivos estabelecidos em uma determinada região possuem diferentes denominações na literatura da área de administração e economia setorial. São utilizadas terminologias diferentes para conceituar atividades econômicas integradas em redes pertencentes a um mesmo território, tais como cluster, arranjos produtivos locais (APL), distritos industriais setoriais, entre outros.

Um dos termos mais encontrados na literatura é o APL, que reflete a idéia de um arranjo produtivo setorial delimitado por um determinado escopo geográfico. Segundo Cassiolato, Lastres e Stallivieri (2008), “o termo APL tem sido crescentemente utilizado tanto por grupos de pesquisa, preocupados por entender os processos de desenvolvimento característicos do atual estágio do capitalismo, como por diversas agências de políticas 
públicas e privadas" (CASSIOLATO; LASTRES; STALLIVIERI, 2008, p. 15). Entretanto, os mesmos autores afirmam que "algumas definições de APL utilizadas nas políticas de promoção na verdade aproximavam-se das de cluster ou de distrito industrial, com parâmetros estimados para sua atuação, composição, funcionamento, grau de maturidade e até forma" (CASSIOLATO; LASTRES; STALLIVIERI, 2008, p. 30). Por essa constatação, percebe-se a existência de diferenças conceituais significativas entre os termos, mas ainda há muita confusão entre seus limites semânticos até mesmo na literatura especializada e nas publicações normativas do setor.

França (2005) descreve que, segundo o Termo de Referência do Grupo de Trabalho Permanente para Arranjos Produtivos Locais (GTP-APL) do Governo Federal brasileiro, um APL deve:

1. ter um número significativo de empreendimentos no território e de indivíduos que atuam em torno de uma atividade produtiva predominante. 2. compartilhar formas percebidas de cooperação e algum mecanismo de governança. Pode incluir pequenas, médias e grandes empresas. (FRANÇA, 2005, p. 19)

A denominação lembrada por França (2005) traz o foco da questão para a existência de uma atividade produtiva específica, ou seja, para a setorização da maioria das atividades econômicas desempenhadas dentro do escopo geográfico do APL. As idéias de cooperação e de mecanismos de governança instituem a necessidade de uma articulação sistêmica de atividades, mediada por uma entidade ou colegiado. Isso remonta às premissas básicas do estabelecimento de arranjos produtivos locais, voltadas para a criação de sistemas de inovação passíveis de gerar competitividade em âmbito regional ou local, através do incentivo de competências coletivas. Entretanto, apesar dos intentos nessa direção, nem sempre a instituição de um APL deriva na obtenção de sistemas produtivos inovadores.

Para Lastres e Cassiolato (2009):

a noção de APL (...) implica uma nova forma de entender e orientar o desenvolvimento produtivo e inovativo. Já as noções de distrito industrial, cluster e outros tipos de aglomerações implicam a suposição de que estas são formas mais propícias de se alcançar tal desenvolvimento. (LASTRES; CASSIOLATO, 2009, p. 117) 
Essa afirmação aponta para um embate ideológico sobre qual seria o conceito que melhor orientaria o desenvolvimento industrial de uma determinada região, sob diferentes aspectos. Entretanto, as diferenças entre os conceitos muitas vezes estão apenas presentes nos nomes atribuídos aos assuntos, tendo em vista que não há ainda uma definição acurada das fronteiras semânticas dos termos utilizados na área de desenvolvimento de pólos tecnológicos e industriais.

Segundo Suzigan et al. (2003), seguindo denominações da Rede de Pesquisa em sistemas Produtivos e Inovativos Locais (Redesist), o APL tem como capacidade essencial "gerar economias externas, incidentais ou deliberadamente criadas, que contribuem para o incremento da competitividade das empresas e, em conseqüência, do sistema ou arranjo local como um todo" (SUZIGAN et al., 2003, p. 2).

A temática da integração sistêmica está diretamente relacionada ao conceito de APL, conforme verificado por Cassiolato, Lastres e Stallivieri (2005). Segundo os autores:

enfatizam-se as oportunidades que a visão sistêmica oferece ao ser instrumental na mobilização e adensamento de diferentes estruturas produtivas. E não se pode esquecer que em alguns casos estarão envolvidas a reestruturação e mesmo a criação de sistemas inteiros. (CASSIOLATO; LASTRES; STALLIVIERI, 2008, p. 34-35).

Dessa forma, verifica-se a necessidade de integração sistêmica entre as partes envolvidas no processo produtivo, em suas múltiplas instâncias, para que haja caracterização efetiva do conceito de APL. Essa integração deve, em consonância com a literatura da área, garantir a emergência de sistemas de inovação que garantam a competitividade do APL baseada nas competências coletivas locais.

Se a integração no intuito de promover a cooperação e o estabelecimento de relações entre os agentes do arranjo produtivo é a principal intenção da constituição formal de um APL, pode-se definir aqui, para caracterização do termo ao longo deste trabalho, a denominação dos arranjos produtivos locais como tentativas formais e institucionalizadas de promover a integração entre os agentes de uma rede produtiva limitada geograficamente, no intuito de garantir a emergência de sistemas locais ou regionais de inovação que permitam aumento da competitividade para os agentes inseridos no arranjo produtivo - e consequentemente para toda a região. 
O conceito de cluster não se afasta dessa constatação, mas não abrange a formalização da tentativa de constituição de relações que fomentem o surgimento de sistemas de inovação. De fato, esses sistemas podem vir a emergir sem a formalização de tais intenções, mas sob o conceito de cluster, não é necessária a existência de uma entidade formal que represente o estabelecimento das relações entre agentes.

Se na conceituação de Porter (1992) o cluster é dado como a aglutinação de empresas de um mesmo setor em um espaço geográfico comum, no intuito de se beneficiar de condições específicas da região para seu segmento e da possibilidade de atividade sinérgica entre seus agentes, gerando competências coletivas compartilhadas, não está explícito no conceito a notoriedade de uma entidade central que formalize a busca desses objetivos.

Para Kotler, Jatusripitak e Maesincee (1997), "um cluster industrial é um grupo de segmentos industriais que compartilham encadeamentos verticais e horizontais positivos" (KOTLER; JATUSRIPITAK; MAESINCEE, 1997, p. 191). Por encadeamentos positivos, os autores definem relações que influenciem de forma benéfica a dinâmica produtiva de toda a estrutura. Essa definição está em consonância com Porter (1998), onde se salienta que os clusters se dão em função de três características básicas:

pelo aumento da produtividade das empresas ou setores componentes; (...)pelo fortalecimento da capacidade de inovação e, em conseqüência, pela elevação da produtividade; e (...)pelo estímulo à formação de novas empresas, que reforçam a inovação e ampliam o cluster (PORTER, 1998, p. 225)

Entre Porter (1992) e Porter (1998) nota-se uma mudança de abordagem que parte da preocupação da caracterização das estruturas de relações e suas benesses para uma descrição das vantagens atreladas ao aumento da produtividade. Entretanto, a inovação não está ligada somente à necessidade de se adequar aos níveis de produtividade impostos pelo mercado. Essa definição restringe-se à caracterização das benesses da formação de clusters em relação à inovação de processos, quando na verdade as inovações de estruturas e de produtos são essenciais para a contínua manutenção dos mercados.

O cluster também pode ser definido como "uma cadeia de relações entre empresas, fornecedores de insumos, clientes e instituições que possuem, além da localização, interesses em compartilhar as vantagens da proximidade" (FUSCO, 2004, p. 64). Essa definição é recorrente entre diversos autores, e há a tendência de aceitação da idéia de que para que haja a 
caracterização de um cluster, é necessário que haja interesse nas vantagens de coabitar o mesmo espaço físico.

Zacarelli (2000) afirma que para que haja o estabelecimento de um cluster, é necessário que diversos fatores estejam alinhados, tais como a coordenação das atividades, objetivos em comum, descoberta de afinidades entre agentes internos, entre outros. O autor mostra assim que muitos dos fatores considerados essenciais para a caracterização de APL estão presentes na caracterização de seu conceito de cluster - que não se opõe em nenhum momento ao que é apresentado pela literatura abordada. Para Zacarelli (2000), a caracterização do cluster passa pela existência de todos os tipos de empresas e instituições de apoio que possam estar relacionados com o produto ou serviço predominante, além de agentes especializados em grande quantidade, aproveitamento de materiais reciclados e subprodutos e, principalmente, cooperação entre as organizações instaladas.

Zacarelli (2000) também leva em conta a necessidade de substituição seletiva permanente das empresas atuantes, dada pela tendência natural dos mercados de beneficiar os melhores desempenhos e processos decisórios através da ampliação do ciclo de vida dos negócios de melhor compatibilidade com o contexto de mercado. A definição defendida por Zacarelli (2000) como de um cluster completo passa pela equidade da importância entre os agentes do arranjo produtivo, uma vez que aborda a uniformidade de nível tecnológico e a preocupação com o caráter de manutenção sistêmica do modelo. Por fim, Zacarelli (2000) considera essencial para a caracterização do cluster a existência de uma cultura da sociedade em sintonia com as atividades desempenhadas pelo arranjo produtivo, assim como pode ser visto em Saxenian (1994).

A grande similaridade entre os conceitos de APL e cluster reforça a idéia de que o que os distingue, realmente, é a existência de uma evidente preocupação com a formalização das atividades desempenhadas pelos agentes internos e instituições correlatas quando tratados os arranjos produtivos locais. Ambos os conceitos repousam sobre as mesmas finalidades (por objetivarem resultados práticos voltados para a consolidação de estruturas produtivas sinérgicas de atuação em mercados sob competências coletivas), mas se distinguem pela intensa recorrência à disposição de regras e incentivos quando colocado em foco o termo APL. Corroborando com a idéia de diferenciação pela estrutura formalizada, Guerrini (2005) salienta que "o cluster é uma rede social (não possui necessariamente acordos formais), simétrica (não possui um elemento coordenador), (...) livre de barreiras (definições menos rígidas de funções, papéis e tarefas dentro das organizações) (...)”(GUERRINI, 2005, p. 132). 
Contudo, há de se observar uma relação de evolução entre os termos. Um cluster pode "evoluir" (não se trata de elevação a um novo nível de valor, mas apenas uma adaptação ao conjunto de idéias ou doutrina presente na estrutura cultural vigente entre os indivíduos responsáveis pelas articulações entre organizações no arranjo produtivo) para o APL, adotando formalidades que constituam relações bem delineadas entre os agentes do mesmo setor localizados na mesma região. Dessa forma, o conceito de APL está contido no conceito de cluster (figura 3, subitem 2.3.2), mas tem especificidades que tangem à formalização das relações entre os agentes.

A contingência do conceito de APL dentro do conceito de cluster implica em estabelecer um nível hierárquico de seu estabelecimento. Dessa forma, antes de se tornar um APL, é necessário primeiro que haja a notoriedade da satisfação das exigências para a constituição de um arranjo produtivo que se aproxime da definição de cluster. Em alguns casos, o surgimento do APL pode ser incentivado, ou até mesmo "forçado", antes da constatação de um princípio de clusterização. Ainda assim, antes da obtenção de uma dinâmica próxima do conceito de APL, haverá o estabelecimento de uma estrutura próxima do conceito de cluster, pois para chegar à primeira é necessário estabelecer a segunda.

Ao diferenciarmos os tipos de arranjos produtivos, é possível que cheguemos a estruturas de coabitação regional ou local de agentes de um mesmo setor sem que haja a priorização do estabelecimento de relações, diretas ou indiretas, entre eles, focando benefícios que não passem por sua articulação em prol do desenvolvimento de inovação. Estas estruturas são explicitadas a seguir.

\subsubsection{Outras estruturas de aglomeração regional de empresas}

O arranjo produtivo setorial concentrado em um determinado espaço físico pode receber outras denominações que escapem aos conceitos originais de cluster e APL. Outros termos como distrito industrial, condomínios de empresas e consórcios são recorrentes na literatura de arranjos produtivos, e merecem ser discutidos à luz da distinção terminológica entre APL e clusters. 


\subsubsection{Distritos Industriais}

Os distritos industriais tiveram seu surgimento no Reino Unido em 1896, instituído por um grupo privado, no intuito de agrupar em uma mesma região certo número de empresas que se beneficiariam coletivamente das melhorias desenvolvidas para sua ocupação, reduzindo custos operacionais com expansão das condições básicas de funcionamento até a área de instalação da planta produtiva (CASTRO, 1993, p. 108).

Segundo Michalet (2003):

\footnotetext{
o distrito baseia-se primeiramente na proximidade geográfica de um conjunto de atores: empresas produtivas, serviços, administrações, mercado de trabalho, infraestruturas, escolas, universidades, centros de pesquisa e desenvolvimento. Essa coexistência está na origem de economias externas que aumentam a produtividade das empresas independentemente de seus tamanhos (economias de escala externas). A proximidade coloca ao seu alcance imediato, com custos de transação baixos, aquilo de que elas precisam para produzir com os mais baixos custos e com melhor qualidade (...) (MICHALET, 2003, p. 209)
}

Benko (1995) define o distrito industrial como "a entidade sócio-territorial que se caracteriza pela presença ativa de uma comunidade humana e de uma população de empresas num espaço geográfico e histórico, onde a comunidade e as empresas tendem a se reunir" (BENKO, 1995, p. 229). Essa definição traz a idéia de integração entre o investimento industrial e a comunidade, conectados pelo espaço de coexistência e pelas múltiplas relações produtivas entre si. Vincular a existência de uma concentração de empresas à comunidade que lhe dará suporte está diretamente ligado à idéia de disponibilidade de mão-de-obra e de recursos para oferecimento de condições favoráveis de trabalho. Tanto a comunidade que cerca o distrito industrial como as empresas que o compõem se beneficiam dessa relação, ainda que essa possa ocorrer de forma desbalanceada - e quase sempre o foi durante os períodos áureos do capitalismo industrial e pós-industrial (HOBSBAWN, 2003). Sob a idéia da constituição de uma comunidade de trabalhadores especializados margeando o conceito de distrito industrial, Putnam (1996) condiciona a relevância do arranjo produtivo à consolidação de um "capital social" ligado ao desenvolvimento econômico regional. Significa dizer que o sucesso do distrito industrial terá alta correlação com a disponibilidade de trabalhadores especializados e condições para que estes possam atingir um alto grau de conhecimento produtivo. 
Quem melhor estudou as relações entre empresas e comunidades em distritos industriais, assim como as causas e consequências de sua consolidação, foi Marshall (1982). No que tange à mão de obra, o autor discorre que:

\footnotetext{
O proprietário de uma fábrica isolada, embora possa conseguir um grande número de operários não especializados, geralmente tem grande dificuldade em obter operários de uma determinada especialização; por outro lado, um operário especializado, uma vez desempregado, tem dificuldade em encontrar outro emprego. Aqui as forças sociais cooperam com as econômicas: há freqüentemente uma amizade profunda entre empregados e empregadores, mas nenhum dos lados gosta de sentir que, caso surja entre eles algum incidente desagradável, têm que continuar a viver um perto do outro; ambos preferem estar certos de que não será difícil romperem as antigas relações caso elas se tornem desagradáveis. Essas dificuldades continuam a ser um grande obstáculo ao sucesso de qualquer empresa em que seja necessária uma determinada especialidade e que não esteja situada nas proximidades de outras empresas similares. (MARSHALL, 1982, p. 234)
}

Se há uma questão intrinsecamente relacionada com a oferta de trabalhadores especializados para a indústria em uma determinada região, esta será a cultura, no âmbito daquilo que Marshall (1982) designa como o processo de formação e acumulação de competências no escopo regional. O mesmo tipo de análise é feita em Saxenian (1994) acerca do Vale do Silício, colocando as relações entre empregados das empresas de TI da região como o grande diferencial para obtenção de saltos contínuos em inovação.

Entretanto para Marshall (1982), outra das vantagens da constituição de distritos industriais é a aquisição de volume produtivo. Segundo o autor, "as principais vantagens da produção em massa são a economia de mão-de-obra, a economia de máquina e a economia de materiais; mas a última destas rapidamente vai perdendo importância relativamente às duas outras" (MARSHALL, 1982, p. 239). Logo, a perspectiva da abundância de mão-de-obra ainda está submetida à lógica da otimização de recursos (principalmente no que tange à relatada economia de mão-de-obra), ou seja, da obtenção de maior produtividade e economia de escala.

A concepção de Marshall (1982) sobre distritos industriais abrange a idéia de setorização, mas isso não é recorrente na literatura. Tanto que a homogeneização setorial de distritos industriais recebeu a alcunha de "distrito industrial marshallino" (VALE, 2007, p. 44), conceito que mais tarde convergiria à denominação de cluster. Ainda ao final da década de 80, Becattini (1990) já apontava s especificidades frente ao conceito usual de distrito 
industrial. Pode-se dizer que, extraídas as peculiaridades da região particularmente confrontada por Becattini à luz da teoria de Marshall (Emília Romana, Itália), é possível alinhar os conceitos de distrito industrial marshallino e cluster como similares - ainda que haja diferenças ocasionais nos resultados aferidos pelos estudos sobre cada um dos termos. Em essência, os conceitos são iguais. Tanto que, Pereira (2000) lembra que "se definirmos cluster a partir de sua tradução literal (...) podemos chamar um distrito industrial - tipo loteamento - de cluster horizontal" (PEREIRA, 2000, p. 93). Obviamente, tal constatação ignora a condição de setorização, mas denota a proximidade entre os termos.

Contudo, ao menos na grande maioria dos textos encontrados, o conceito de distrito industrial mais comum na literatura não incorpora a necessidade de setorização - embora sempre esteja claro um determinado nível de compartilhamento de recursos. Por isso, distingue-se do conceito mais aceito de cluster, que denota uma especialização produtiva regional. Um bom exemplo dessa ausência de necessidade de setorização sobre o conceito usual de distrito industrial pode ser visto em Vieira (2009), quando afirma que "de acordo com os Indicadores Industriais da Zona Franca de Manaus, as indústrias do Distrito Industrial abrangem diferentes subsetores industriais, como: Eletrônico, Bens de Informática, Relojoeiro, Duas Rodas (...)”(VIEIRA, 2009, p. 77), entre outros.

\subsubsection{Consórcios}

Os consórcios, segundo Young (2008), são por definição formal:

\footnotetext{
associação de companhias ou qualquer outra sociedade, sob o mesmo controle ou não, que não perderão sua personalidade jurídica, para obter finalidade comum ou determinado empreendimento, geralmente de grande vulto ou de custo muito elevado, exigindo para sua execução conhecimento técnico especializado e instrumental técnico de alto padrão. (YOUNG, 2008, p. 364)
}

Por essa definição inicial, percebe-se a constituição de uma associação com finalidade específica entre duas ou mais organizações constituídas formal e juridicamente. O conceito de Young (2008) está de acordo com a definição de Fiuza (2008):

Consórcio de empresas é a associação de duas ou mais sociedades civis ou comerciais, que, sem perder sua individualidade, se reúnem para a consecução de 
empreendimento comum, que individualmente não conseguiriam. Essas sociedades consorciadas poderão estar sob o controle de uma delas ou não. (FIUZA, 2008, p. 692)

Mais uma vez, entende-se que o foco da definição está na associação de duas ou mais entidades já constituídas em prol de uma ação conjunta. Essa ação conjunta pode se configurar em participações coletivas em propostas de serviços, principalmente no caso de licitações (OLIVEIRA, 2007), ou mesmo em desenvolvimento conjunto de novas tecnologias. A participação no empreendimento ocorre por regime de cotas, proporcionais aos recursos aportados para constituição do consórcio ou por definição de instrumento formalizado entre os agentes (YOUNG, 2008).

Nota-se que para a existência do consórcio, é necessário, primeiramente, haver uma finalidade comum. O emprego de recursos coletivos com finalidades comuns denota a constituição de vínculos formais em prol de uma ação onde os ganhos são proporcionais ao empenho das partes consorciadas. Dessa forma, figuram entre os elementos essenciais do conceito de consórcio de empresas a existência de finalidade comum e associação. Entretanto, a concentração em uma mesma região ou compartilhamento de um mesmo espaço operacional não está necessariamente inserido no conceito de consórcio, podendo se configurar por razões ligadas às particularidades das relações estabelecidas, mas não faz parte da definição geral.

Uma espécie de consórcio diretamente relacionada com o compartilhamento de custos ligados ao espaço ocupado é o condomínio de empresas (GUERRINI, 2005).

\subsubsection{Condomínios de Empresas}

Os condomínios de empresas surgiram como uma derivação dos distritos industriais e dos consórcios. Segundo Guerrini (2005), “a partir do conceito de consórcio, surgiram as definições de consórcio modular e condomínio industrial” (GUERRINI, 2005, p. 115), entre outros. Segundo o autor:

o condomínio industrial é uma rede burocrática (baseada em acordo formal), assimétrica (a coordenação é feita pela unidade produtiva), estática (os acordos possuem a duração do projeto), modular (a unidade produtiva concentra-se na atividade-fim, delegando as atividades que não estão diretamente relacionadas à 
missão da empresa), tangível (as relações surgem de oportunidades para compartilhar atividades da cadeia de valores). (GUERRINI, 2005, p. 132)

Essa definição não colide com a definição usual de condomínio, caracterizada na jurisprudência. Segundo Pereira (2006), "há condomínio quando a mesma coisa pertence a mais de uma pessoa, cabendo a cada um deles igual direito, idealmente sobre o todo e a cada uma das partes" (PEREIRA, 2006, p. 175). No caso dos condomínios de empresas, verifica-se o interesse em compartilhar recursos de diversas naturezas (principalmente no que tange aos recursos físicos de instalação) apara redução dos custos operacionais. Segundo Rainho (2008), até mesmo os custos com mão-de-obra relacionada à manutenção das instalações é dividido, pela terceirização. Segundo o autor, "a indústria autônoma avançou ainda mais ao introduzir o conceito de condomínio de empresas (...) a diferença é que o funcionário do condomínio não tinha vínculos com a empresa cliente, e sim com a empresa contratante de seus serviços, terceirizada" (RAINHO, 2008, p. 36).

Há pelo menos dois conceitos relevantes encontrados na literatura acerca dos condomínios de empresas, e ambos têm como cerne o compartilhamento de estruturas e facilidades ligadas à instalação de empresas em um dado ambiente.

Um dos conceitos de relevância pode ser encontrado na análise de Boyer (1998) sobre o Programa Ford 2000, no qual a empresa trazia "certos fornecedores para produzirem dentro de suas instalações, em áreas usualmente ocupadas por processos transferidos para a Argentina ou terceirizados" (BOYER, 1998, p. 285), desdobramento da cisão da Autolatina. Mostra-se evidente a preocupação em redução das distâncias e reestruturação logística dentro da cadeia produtiva de itens de demanda dependente. Muitas vezes, os custos de manutenção das instalações também são compartilhados. Esse tipo de recurso dinamizou em vários aspectos a produção de veículos, agrupando organizações envolvidas em estágios distintos do processo produtivo de um mesmo produto final sob a expectativa de gerar maior entrosamento entre as equipes alocadas em diferentes etapas, culturas organizacionais de maior simetria (promovida pela maior facilidade de troca de conhecimentos) e, logicamente, redução de custos operacionais que vão desde a óbvia reconfiguração dos planos logísticos até o melhor aproveitamento do capital humano e social. Este compartilhamento de fatores associados à produção pode incluir a coabitação de plantas produtivas ou constituição de plantas distintas, desde que os processos estejam associados. É o que reconhece Fusco (2004) quando avalia a implantação da planta produtiva da Fiat em Betim, MG, relatando que "a planta (...) se encontra em pleno processo de implantação do conceito de condomínio industrial (...) 
induzindo seus fornecedores a relocar suas plantas para a proximidade de sua principal linha de montagem, ou mesmo, em alguns casos, para dentro de sua planta principal" (FUSCO, 2004, p. 132).

A mesma idéia de compartilhamento de uma área comum está presente no outro conceito de maior relevância, mas não leva em consideração a necessidade de integração em torno de projetos comuns. Esse é o conceito mais recorrente sob o termo condomínio de empresas (e sua variação típica sob o escopo desse trabalho, condomínio industrial) na literatura mais atual, com menos de cinco anos. Sustenta-se na idéia de que empresas de diferentes setores podem se valer da vantagem de se instalarem em uma mesma região por haver uma convergência de facilidades básicas para qualquer tipo de indústria. Algumas dessas vantagens podem ser, entre outras, disponibilidade de redes de fornecimento de energia, vias de acesso e isenções fiscais (muito recorrentes a partir da década de 1980 até os dias de hoje). Um exemplo que sustenta a idéia de vantagens operacionais atreladas ao conceito condominial vem de um dos chamados Tigres Asiáticos. Ao analisar a instalação do Eco-Industrial Park em Singapura, Seetoh e Ong (2008) relatam que:

\footnotetext{
em termos infra-estruturais e de serviços de utilidade, o conceito de condomínio foi adotado na Ilha Jurong onde serviços, assim como infra-estrutura, utilidades e serviços de logística são compartilhados entre as companhias locais para reduzir o custo de capital e tornar possível um que as operações se iniciem mais rápido. Uma outra iniciativa é o corredor de serviços multiuso, que pode ser utilizado para abastecer as instalações, estoques e transferir produtos para companhias na Ilha Jurong. Outros serviços compartilhados incluem brigada de incêndio industrial, tratamento e incineração de dejetos (SEETOH; ONG, 2008, p. 129)
}

De certa forma, ambos os conceitos de condomínio de empresas, tanto aquele que foca na estrutura coordenada de organizações ocupando um mesmo espaço físico em função de um produto comum quanto aquele que abrange apenas a proximidade de empresas de nichos diferentes do mercado em torno do compartilhamento de facilidades que propiciam vantagens comuns, se desdobraram em casos práticos de empreendimentos imobiliários destinados à indústria, segmentados ou não. Estes empreendimentos, que se valem da oportunidade de compartilhamento de recursos para suprir a necessidade recorrente de eficiência operacional das indústrias, acabaram se tornando um nicho lucrativo de negócios para incorporadoras e empresas de construção. A grande procura do tipo de instalação condominial, de custos compartilhados, advém de mecanismos que corroboram com a afirmação de Melaniphy 
(1976), pela qual "é muito caro construir prédios para uso individual, enquanto um empreendedor industrial pode simplesmente contratar o espaço que necessita em um prédio já construído" (MELANIPHY, 1976, p. 9). Em Campinas, por exemplo, um desses empreendimentos condominiais voltados para a indústria é o Techno Park, iniciativa do grupo DPaschoal em realizar um cluster de empresas de tecnologia sem segmentação definida.

Ambos os conceitos de condomínio industrial, segmentado e não segmentado, não dividem, necessariamente, as áreas físicas em diferentes construções autônomas. Na verdade um mesmo prédio (ou locação em um prédio) pode alocar diversas organizações distintas de forma condominial. De acordo com Peckham (2006), “todo tipo de prédio comercial, de escritórios, e industrial é passível de ser dividido e vendido (...) Pelo conceito de expansão condominial, você pode transformar o projeto de um condomínio no projeto de mais seis condomínios" (PECKHAM, 2006, p. 301). Sob o enfoque do negócio de estabelecimento de condomínios industriais (e o mesmo vale para os residenciais), Peckham (2006) ressalta que todo espaço útil (ou que ainda não é útil, mas que pode vir a ser um dia) pode ser comercializado ou colocado em disponibilidade para ser alugado ou adquirido no mercado imobiliário.

O conceito geral de condomínio de empresas pode ser definido então pelo compartilhamento de custos relacionados à ocupação espacial e ao conjunto de variáveis logísticas conectadas aos processos industriais, em seus diversos segmentos.

\subsubsection{Mapeamento conceitual hierárquico dos tipos de agrupamentos abordados}

As relações entre empresas podem se constituir em diversos formatos, configuradas pelas muitas particularidades a serem distinguidas. Para as finalidades práticas dessa pesquisa, procurou-se desenvolver uma taxonomia hierárquica próxima ao verificado na literatura da área, encontrando-se uma relação lógica entre os termos dada pelas definições verificadas.

Parte-se do termo geral "relação entre empresas", que envolve qualquer tipo de relação estabelecida entre duas organizações formalmente constituídas, cada uma preservando sua identidade. Essas relações podem se desdobrar em competição ou sinergia, muitas vezes alternando esses estados conforme o nível ou instância de relacionamento.

No âmbito da competição, é possível que ocorra concorrência entre empresas que desenvolvam produtos, serviços ou tecnologias similares ou substitutivos, disputando uma fatia de seu mercado. Essa concorrência incita um movimento de melhoria de processos e 
produtos que possa agregar valor ao que é oferecido ou tornar mais eficiente sua produção, impactando no preço percebido pelo mercado. Esse processo de inovação em busca da competitividade pode se valer de várias formas das benesses auferidas pelos diferentes tipos de aglomeração espacial. A mais geral das vantagens repousa sobre o compartilhamento de custos e aproveitamento das oportunidades distribuídas sob um determinado escopo espacial. Em sintonia com essa vantagem estão todos os conceitos de concentração espacial de empresas.

O conceito de relação entre empresas por competição dá origem ao conceito de relação por sinergia, pois as empresas tendem a se organizar cooperativamente no intuito de dinamizar suas operações em função de redução de custos e melhoria técnica para se manterem no mercado. Das relações de sinergia, um termo específico é a aglomeração espacial de empresas.

Abaixo da aglomeração espacial de empresas estão distribuídos todos os termos e designações abordados nessa pesquisa. Tendo como termo geral a aglomeração espacial de empresas, teríamos como termos específicos, de acordo com a literatura abordada, os regimes de homogeneidade e heterogeneidade da atividade desempenhada. As aglomerações espaciais onde a atividade fim mais relevante é homogênea são os agrupamentos setorizados de empresas, onde se encaixam os conceitos de cluster e distrito industrial marshallino. As aglomerações espaciais não setorizadas, ou seja, de atividade fim heterogênea, são os distritos industriais comuns e condomínios de empresas. A Figura 3 delimita graficamente o encadeamento dos termos. Note-se que o termo condomínio de empresas tem a possibilidade de estar relacionado a diversas formas de arranjos produtivos, seja em distritos industriais do tipo heterogêneo ou marshallino, ou mesmo APL. 
Figura 3

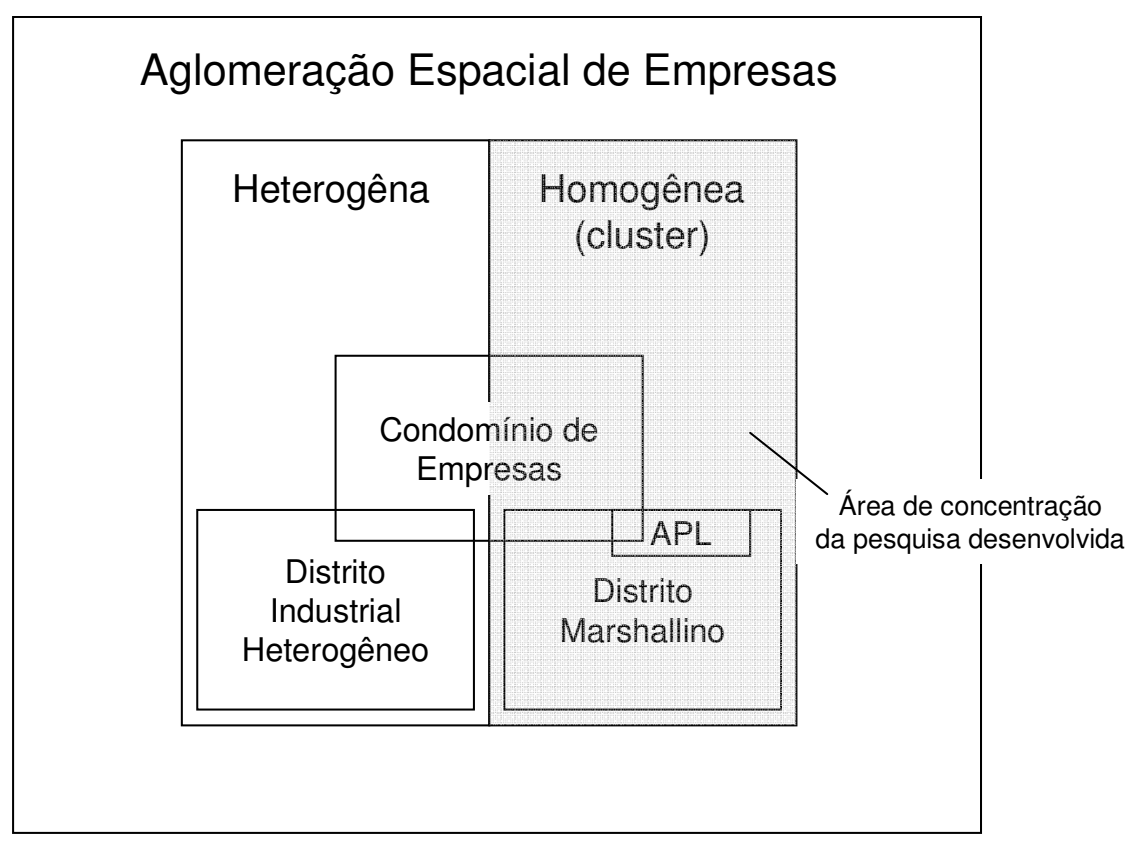

Representação Gráfica do Mapeamento Conceitual Hierárquico dos tipos de Agrupamento Espacial de Empresas

Fonte: Autor

O elemento que denota a constituição de distritos industriais em aglomerações espaciais de empresas, sejam heterogêneas ou homogêneas (não setorizadas ou setorizadas), é a formalização da iniciativa de reunir agentes de atividade industrial dentro de um espaço delimitado. Entretanto, é possível que haja a formação de um adensamento heterogêneo de indústrias ou mesmo o surgimento de um cluster sem a formalização da intenção de fazê-lo. Assim, no âmbito dos empreendimentos de aglomeração espacial de empresas setorizados, um APL é necessariamente um distrito marshallino e um cluster, mas um cluster não é necessariamente um APL.

A pesquisa aqui desempenhada aborda, principalmente, as aglomerações espaciais setorizadas, nas quais as vantagens auferidas estão além do mero compartilhamento de facilidades do âmbito espacial, mas que também envolvem as relações estabelecidas entre as organizações e agentes no sentido de dinamizar o desenvolvimento de inovação. 


\subsection{Tecnologia da Informação e Sistema Capitalista}

O termo Tecnologia da Informação possui vários conceitos na literatura científica. Entretanto, o oferecido por Manuel Castells (1999) chama maior atenção pelo escopo delimitado:

Entre as tecnologias de informação, incluo, como todos, o conjunto convergente de tecnologias em microeletrônica, computação (software e hardware), telecomunicações/radiodifusão, e optoeletrônica. Além disso, diferentemente de alguns analistas, também incluo nos domínios da tecnologia de informação a engenharia genética e seu crescente conjunto de desenvolvimentos e aplicações. (CASTELLS, 1999, p. 49)

Todas as tecnologias abordadas por Castells (1999) em sua conceituação de TI são elementos representativos da ciência contemporânea aplicada. Como o próprio autor evidencia em seu texto, a maioria dos demais pesquisadores e analistas tem a engenharia genética como um campo distinto das tecnologias de informação. Autores como Roger Mansfield, por exemplo, vêm a TI como:

\footnotetext{
uma categoria de desenvolvimentos tecnológicos relativos à criação, transmissão, manipulação e apresentação de dados. Estes desenvolvimentos são largamente baseados em circuitos microeletrônicos de chips de silício e principalmente direcionados à comunicação, computação e controle. (MANSFIELD, 1984, p. 216)
}

De certo modo, há uma convergência teórica em torno do computador como equipamento chave da TI, assim como do silício como seu material emblemático. Buckland (1991) também enxerga a Tecnologia de Informação como um conceito relacionado em um "senso restrito para denotar comutação eletrônica e tecnologias de comunicação" (BUCKLAND, 1991, p. 69), mas alerta que isso é um sinal da mudança do paradigma tecnológico. As tecnologias voltadas para a criação, registro, armazenagem, recuperação e disseminação de informações antes do advento do computador também eram passíveis de serem consideradas no rol de TI em suas épocas de utilidade. A emergência de novas tecnologias para a execução desses processos envolvendo a informação condicionou a associação do termo ao novo paradigma tecnológico da informática. 
Lucas (1999) enxerga três componentes principais inclusos nas tecnologias de informação, sendo eles os computadores, as bases de dados e as redes de comunicação. Segundo o autor, outros dispositivos como "sistemas de correio de voz, máquinas de fax, assistentes pessoais digitais como o Palm Pilot, e outros dispositivos eletrônicos similares que promovem a computação, estocagem e comunicação de dados" (LUCAS, 1999, p. 5) estão inseridos no rol das tecnologias de informação. Todo um setor produtivo emergiu dessas novas tecnologias. Esse novo setor produtivo - que vive um constante estágio de formulação de sua identidade (CASTELLS, 1999) - ainda possui difícil conceituação teórica, mas notável importância prática. Segundo Laurindo et al, "o conceito de Tecnologia da Informação é mais abrangente do que os de processamento de dados, sistemas de informação, engenharia de software, informática ou conjunto de hardware e software, pois também envolve aspectos humanos, administrativos e organizacionais" (LAURINDO et al, 2001, p. 160).

A emergência das novas tecnologias de informação, associadas à computação eletrônica de dados, deu-se início nos anos 1930, apoiada pelo desenvolvimento de novos componentes eletrônicos, conforme mostra Castells (1999):

Apesar dos antecessores industriais e científicos das tecnologias da informação com base em microeletrônica já poderem ser observados anos antes da década de 40 (...), foi durante a Segunda Guerra Mundial e no período seguinte que se deram as principais descobertas tecnológicas em eletrônica: o primeiro computador programável e o transistor, fonte da microeletrônica, o verdadeiro cerne da Revolução da Tecnologia da Informação no século XX. (Castells, 1999, p. 58)

O primeiro computador (o ENIAC) foi terminado em 1945, desenvolvido pela Universidade da Pensilvânia, ainda utilizando válvulas e medindo a altura de um edifício de três andares (CAVALCANTI, 1996). O ENIAC possuía 18 mil válvulas a vácuo e mil e quinhentos relês, consumindo cerca de $170 \mathrm{~kW}$ de potência (ALLAN, 2001). Após o advento do transistor, já em 1946, houve um avanço sem precedentes no desenvolvimento de dispositivos computacionais, que a cada descoberta passava a diminuir de tamanho e crescer em produtividade. A utilização de tal tecnologia não pode ser encarada como a incorporação de uma descoberta isolada no processo produtivo. Pelo contrário. Mesmo os primeiros computadores dependeram da integração de vários projetos distintos para que pudessem se tornar viáveis. O salto quântico que levou a TI das válvulas do Eniac para os primeiros transistores foi crucial para o estabelecimento de uma nova tendência mundial. A própria 
pulverização das unidades de processamento passa pela redução de espaço e custos que isso permitiu. Sobre isso, Castells (1999) diz que:

\begin{abstract}
O transistor, inventado em 1947 na empresa Bell Laboratories em Murray Hill, no estado de Nova Jersey, pelos físicos Bardeen, Brattain e Schockley (...), possibilitou o processamento de impulsos elétricos em velocidade rápida e em modo binário de interrupção e amplificação, permitindo a codificação da lógica e da comunicação com e entre as máquinas: esses dispositivos têm o nome de semicondutores, mas as pessoas costumam chamá-los de chips (na verdade, agora constituídos de milhões de transistores). (CASTELLS, 1999, p. 58)
\end{abstract}

Os primeiros transistores, das décadas de 40 e 50, tinham sua estrutura pouco complexa, mas já se baseavam (como as válvulas que os antecederam) nos princípios binários booleanos. Sua importância pode ser comprovada nos manuais técnicos da área, tal qual em Malvino (1987): Antes de 1950 todo o equipamento eletrônico utilizava válvulas, aquelas com um
bulbo de baixo brilho que numa determinada época dominaram a nossa indústria. O
aquecedor de uma válvula típica consumia muitos watts de potência. Por isso, os
equipamentos a válvula exigiam uma fonte de alimentação robusta e criavam uma
boa quantidade de calor que constituíam um problema a mais para os projetistas. O
resultado eram os equipamentos pesados e antiquados tão difundidos naquela época.
(...) Em 1951, Schockley inventou o primeiro transistor de junção. Foi um desses
acontecimentos que mudam todas as regras. (...) O impacto do transistor na
eletrônica foi enorme. Além de iniciar a indústria dos multi-bilhões de dólares dos
semicondutores, o transistor contribuiu para todas as invenções relacionadas, como
os circuitos integrados, componentes optoeletrônicos e microprocessadores.
Praticamente todos os equipamentos eletrônicos projetados hoje em dia usam
componentes semicondutores. As mudanças foram mais perceptíveis nos
computadores. O transistor não revisou a indústria dos computadores, ele a criou.
(MALVINO, 1987, p. 132)

Todo o desenvolvimento posterior à descoberta do transistor pela Bell Labs seguiu a mesma lógica de automação de processos computacionais, baseada nos métodos algébricos matemáticos desenvolvidos por George Boole em 1854 (NAMBIAR, 2000). Até mesmo a 
automação de processos através da pré-programação de rotinas digitais não foi iniciada no século XX. Pelo contrário, conforme discorre Coriat (1983):

\footnotetext{
A automação não é um fenômeno novo (...). Máquinas programadas que substituem o trabalho efetuado manualmente existem praticamente desde o surgimento da indústria. Os historiadores do maquinismo do século XIX, como Ure ou Babbage, descrevem detalhadamente (...) os automatismos das séries de operações efetuadas mecanicamente por máquinas. (CORIAT, 1983, p. 7 apud LOJKINE, 2002, p. 83)
}

A novidade trazida pelo desenvolvimento das novas tecnologias era a velocidade de processamento que os dispositivos eletrônicos possibilitavam. Cálculos que antes demandavam dias para processamento passaram a ser desenvolvidos em poucos segundos. Algumas das mais importantes finalidades encontradas para esse incremento de capacidade de cálculo foram aquelas relacionadas com as operações militares da década de 1940 (FLAMM, 1988). Muitas das tecnologias utilizadas para o desenvolvimento do computador e seus dispositivos correlacionados vieram do esforço de guerra. Entre os anos de 1930 e 1960, algumas empresas como a International Business Machines (IBM) foram financiadas pelo governo americano para desenvolvimento de Tecnologia de Informação para atividades militares (FLAMM, 1988). Estes esforços eram justificados pela entrada dos Estados Unidos na Segunda Guerra Mundial, mas tinham pretensões que iam além das utilidades militares do que era desenvolvido. A IBM e o MIT (Massachussets Institute of Technology) trabalhavam junto ao Departamento de Defesa dos Estados Unidos em diversos projetos militares, desenvolvendo a tecnologia que, mais tarde, viria a compor o rol de produtos da IBM voltados para o mercado de TI aplicada aos negócios (ALLAN, 2001).

Após a Segunda Guerra Mundial, o governo americano continuou investindo no desenvolvimento de TI. Em 1946, o congresso americano aprovou o estabelecimento do Escritório de Pesquisa Naval (Office of Naval Research), um importante centro de pesquisas para a história da Tecnologia da Informação (FLAMM, 1988). Este órgão supervisionava os desenvolvimentos em TI promovidos pelo Departamento de Defesa norte-americano Entre 1946 e 1955, o governo americano dominou o desenvolvimento de TI, especificamente com finalidades militares. Mas a partir de 1955, o mercado de TI para negócios civis aumentou muito, oferecendo maior participação para as empresas privadas no desenvolvimento de produtos para suprir à demanda. Ainda com o aumento da demanda, "usuários 
governamentais ainda dominavam os computadores científicos de alto desempenho" (FLAMM, 1987, p. 42).

Entre os anos de 1965 e 1975, houve um forte aumento do mercado de computadores comerciais, o que aumentou o número de produtores no cenário americano. Entretanto, "apenas algumas poucas firmas firmemente instaladas em específicos nichos de mercado sobreviveram" (FLAMM, 1987, p. 42). Começava uma era de competição acirrada entre as empresas de Tecnologia da Informação. $O$ investimento em inovação passou a ser um diferencial produtivo e de mercado. Ao passo que os novos produtos, que traziam maiores vantagens para os usuários, eram plenamente disputados pelo mercado, novos métodos produtivos baseados em novas tecnologias garantiam a redução de custos da produção, reduzindo com isso os preços dos produtos. A regra do setor passou a ser a inovação constante. Para isso, eram necessários recursos materiais e humanos, abundantes nos Estados Unidos do pós-guerra.

Segundo Coopey (2004):

\footnotetext{
Muitas razões colaboraram para o sucesso das empresas de TI americanas, desde a vantagem do primeiro movimento, a escala e escopo dos grandes empreendimentos americanos, conexões atingidas, o papel da pesquisa e desenvolvimento militares e sua procura por obtenção de tecnologias, a primazia do livre mercado e, mais recentemente, os efeitos dos clusters e redes de trabalho. (COOPEY, 2004, p. 2-3)
}

A indústria de TI passou a produzir produtos essenciais para a dinamização da produção em outras indústrias dos mais diversos setores (LOJKINE, 2002). Quando o investimento em pesquisa e desenvolvimento oriundo da iniciativa privada começou a superar os investimentos estatais, o mercado de tecnologia se tornou mais dinâmico e conectado à lógica do capital, especialmente voltado para a redução dos custos, aumento dos lucros e melhoria dos produtos (COOPEY, 2004).

O sucesso da indústria de TI sob a lógica capitalista se deve a uma máxima popular que descreve a dinâmica de todo o sistema: tempo é dinheiro. O tempo é para o capitalismo, mais do que em qualquer outro sistema econômico, um recurso primordial. Segundo Caronia (1996), "o relógio é o modelo da perfeição mecânica de todas as demais máquinas industriais, além de ser o instrumento que permite a operatividade básica, sem a qual, a organização da vida moderna, a começar pela fábrica, seria impensável" (CARONIA, 1996, p. 18). O tempo é o principal determinante da vida contemporânea, e a economia de tempo representa, sob 
muitos aspectos, redução de custos e aumento dos lucros. A Tecnologia da Informação, entre outras vantagens, trouxe para o processo de produção capitalista a economia de tempo em funções que antes demandavam dias para processamento de informações, passando a fazê-lo em frações de segundos (LOJKINE, 2002).

Após a década de 1970, passou a se tornar impossível a dissociação da indústria de TI do cenário capitalista. Os produtos voltados para o processamento, armazenagem e comunicação de informações passaram a ter uma escala valorativa baseada na eficiência, ou seja, maior volume de informações em menor tempo e menor custo. Para competir nesse tipo de mercado era necessário inovar, e toda inovação se baseia em um elemento básico: informação (CASTELLS, 1999). Logo, desenhou-se um ciclo de melhoria de produtos para sobrevivência em um mercado voltado para a inovação contínua que ressaltou a importância da TI, e conseqüentemente, da indústria relacionada a ela.

As novas tecnologias de informação dinamizaram a comunicação, fazendo com que regiões inóspitas ficassem acessíveis pelo uso de equipamentos conectados à rede mundial de computadores (CASTELLS, 1999). O dinamismo imposto pelo mundo integrado, com mercados cada vez mais sensíveis às ocorrências externas, demanda um aparato que permita a interação entre os agentes sociais de diferentes comunidades e nações em tempo real, uma vez que o capital não está mais isolado a uma única região. Mercados integrados dependem de uma comunicação eficiente que impeça as barreiras físicas de se expressarem como um obstáculo para a obtenção de lucro em lugares espacialmente intangíveis pelos investidores (BAUMAN, 1999). Essa necessidade do sistema, agregada à dinâmica cada vez mais intensa do mercado internacional, acaba por estabelecer relações bivalentes de causa e conseqüência com as inovações tecnológicas de informação. Isso se reflete em todas as demais relações ocorridas na malha social, com fortes conseqüências para as culturas regionais (CASTELLS, 1999).

O aumento da velocidade de comunicação oferecido pelas tecnologias de informação frente ao sistema capitalista acabou por delimitar uma zona de interdependência entre um e outro. O aparato informacional é agora parte integrante e representativa do sistema, ao passo que a indústria por trás de sua criação e manutenção ocupa, por assim dizer, um lugar de destaque entre os setores produtivos. Toda modificação tecnológica de informação exerce influência sobre a dinâmica do sistema, redimensionando rotinas e re-escalonando relações entre os agentes sociais, o que mostra a importância da relação entre a TI e o capitalismo. Tal qual nos mostra Maria da Conceição Tavares em prefácio à obra de Dantas (2002): 
O novo modelo do sistema, em vias de amadurecimento, tem sua trajetória definida pelas tecnologias digitais. Ao reduzir qualquer informação a seqüências de zero e um - textos, som, imagem, tudo agora em bits -, a digitalização viabilizou o processo de apropriação e privatização da informação, pois foi possível passar a tratá-la por uma mesma medida: o tempo. Gerar e transmitir informação consome tempo de trabalho, mas receber informação poupa tempo de trabalho. A acumulação de capital procura soluções para tornar disponível um valor de uso resultante desse tempo poupado e para obrigar o usuário desse valor a reconhecer e remunerar o tempo empregado para tornar viável esse processo. (TAVARES, 2002, p. 92)

Dessa forma, o dinamismo engendrado pelas tecnologias da informação não se encontra apenas na velocidade de tráfego de dados, mas também na obtenção de informações primordiais para estabelecer vantagens competitivas em um sistema cada vez mais sujeito às concorrências (apesar de isso não ocorrer em alguns ambientes específicos de monopólio declarado ou velado). Isso significa uma redução no tempo de pesquisa em soluções para diversos setores da economia, assim como aumento da eficiência na recuperação de dados em diferentes instâncias produtivas. Como ressalta Tavares (2002), essa nova condição gera a necessidade da remuneração de quem viabiliza esse processo de redução do tempo das operações envolvendo a geração e manuseio de informações. A valoração dos trabalhos envolvendo a manutenção dos processos informacionais é uma das discussões mais pertinentes ao novo momento do capitalismo, e encontra lugar comum no ambiente de desenvolvimento das tecnologias de informação (SANTAELLA, 2003).

Diante das descobertas eletrônicas que beneficiaram a emergência das tecnologias de informação estão situados dois importantes pólos industriais tecnológicos ligados às pesquisas e desenvolvimentos da área: a chamada Rota 128 em Massachusetts e o Vale do Silício na Califórnia. Ambos tiveram sumária importância no desenvolvimento de TI, assim como sua comercialização e divulgação mundo afora (CASTELLS, 1999). A Rota 128 é a área de estabelecimento de escritórios de planejamento e desenvolvimento de indústrias tradicionais do segmento de eletrônicos. Já o Vale do Silício é um pólo de novas idéias administrativas e surgimento de novas tecnologias, contando com uma diversidade ampla de empresas do segmento informacional aliada ao fluxo incessante de pesquisas na área (SAXENIAN, 1994). De modo geral, a empresa da nova fase do sistema capitalista, tinha características distintas daquela do industrialismo [fase do sistema capitalista baseado na produção industrial de bens de consumo, compreendida entre 1840 e 1920, aproximadamente - segundo Lojkine (2002)], como enuncia Castells (1999): 
A própria empresa mudou seu modelo organizacional para adaptar-se às condições de imprevisibilidade introduzidas pela rápida transformação econômica e tecnológica. A principal mudança pode ser caracterizada como mudança de burocracias verticais para a empresa horizontal. (CASTELLS, 1999, p. 184)

A indústria de TI havia modificado completamente a cultura das organizações inseridas no contexto capitalista de produção. Não somente os arranjos internos das empresas se modificaram, mas também as relações que estas mantinham entre si. Os clusters passaram a se mostrar exemplos de um novo modo de produção, onde a competição convivia lado a lado com a sinergia (PORTER, 1992). Clusters como o Vale do Silício contribuíram diretamente para as mudanças sistêmicas ocorridas em consequiência do avanço da TI. Como aponta Castells (1999):

O avanço gigantesco na difusão da microeletrônica em todas as máquinas ocorreu em 1971 quando o engenheiro da Intel, Ted Hoff (também do Vale do Silício), inventou o microprocessador, que é o computador em um único chip. Assim, a capacidade de processar informação poderia ser instalada em todos os lugares. (CASTELLS, 1999, p. 59)

O invento do microprocessador acabou por destituir conceitos já sedimentados sobre o processamento de informações. Em primeiro lugar, pairava sobre o imaginário das tecnologias de informação a nítida impressão de uma centralidade do processamento dos dados. Imaginava-se que o futuro da informática estava diretamente ligado aos grandes computadores de instituições e universidades, que reportariam aos terminais localizados em residências e demais pontos das comunidades às quais se dedicavam a servir. Esse ideário sobre o futuro dos computadores passava por um nítido conceito de controle centralizado das operações. A descoberta do microprocessador lançou os conceitos centralizadores na obsolescência, como percebe Castells (1999) quando diz que "o advento do microprocessador em 1971, com a capacidade de incluir um computador em um chip, pôs o mundo da eletrônica e, sem dúvida, o próprio mundo, de pernas para o ar." (CASTELLS, 1999, p. 61). Era o fim da dependência das unidades centrais. O uso do aparato informático para processamento de informações passaria a ocorrer então de forma autônoma, longe das instituições de pesquisa ou das indústrias. Este foi o primeiro passo para a concepção dos computadores pessoais (CASTELLS, 1999). 
No desenvolvimento dos novos computadores de mesa, podemos perceber a forte influência do ideal libertário dos anos 1960, ao passo que a maioria dos cientistas, técnicos e inventores que contribuíram para seu surgimento tinha um forte vínculo com a era hippie da cultura americana (SAXBY, 1990). Especialmente no Vale do Silício, a maioria dos envolvidos com as novas empresas de informática teve contato com as idéias dos movimentos a favor da liberdade difundidos na costa Oeste e no meio-Oeste dos Estados Unidos. Reflexo de uma nova cultura, as unidades de processamento se descolaram, através do circuito integrado e do microprocessador, das regras de centralização do processamento de dados (SAXBY, 1990).

Os jovens pesquisadores tiveram uma participação especial no processo de renovação tecnológica iniciado pela descoberta dos microprocessadores. O Altair, tido por muitos como o primeiro computador pessoal de mesa com processamento independente, teve seu protótipo construído em 1975 por Ed Roberts, em Albuquerque, Novo México. Mas o sucesso de comercialização de computadores pessoais veio com o intento de dois jovens da Califórnia, Steve Jobs e Steve Wozniac, que na garagem de seus pais em Menlo Park, Vale do Silício, fundaram a Apple Computers (CASTELLS, 1999). Não tardou para que a IBM passasse a comercializar seus próprios computadores pessoais, inaugurando o famoso termo PC, ainda que continuasse na produção de grandes computadores e mainframes (FLAMM, 1988). A descentralização do processamento e arquivamento de dados é um dos grandes saltos conceituais ocorridos nos anos 1970 para a Tecnologia de Informação (CASTELLS, 1999).

A atual malha de conexões estabelecidas pela rede mundial de computadores segue os mesmos princípios daquela época. Conforme sugere Castells (1999), "esse sistema tecnológico, em que estamos totalmente imersos nos anos 90, surgiu nos anos 70" (CASTELLS, 1999, p. 64). A internet, baseada na descentralização da informação ocorrida com o advento do computador pessoal, tem a função de estabelecer conexões entre as unidades de processamento e arquivamento de dados espalhadas pelo globo, fazendo com que usuários do mundo inteiro tenham acesso às informações disponibilizadas na rede (SANTAELLA, 2003).

Castells (2003) afirma que a internet surgiu do desdobramento de um pequeno programa de comunicação desenvolvido pelo Escritório de Técnicas de Processamento de Informações (Information Processing Techniques Office - IPTO) da Agência Americana de Projetos de Pesquisas Avançadas (Advanced Research Projects Agency - ARPA), que tinha como função "permitir aos vários centros de computadores e grupos de pesquisa que trabalhavam para a agência compartilhar on-line tempo de computação" (CASTELLS, 2003, 
p. 14). A rede constituída sob essa tecnologia inicial era chamada ARPANET. Entretanto, a origem da internet expressa por Castells (2003) somente é contestável quando verificada sob a ótica de outros autores, que posicionam o embrião da rede internacional de computadores em uma rede maior do que as suportadas pelos Estados Unidos. Segundo Franda (2001):

\footnotetext{
Princípios de autoridade descentralizada e padrões técnicos inclusivos, assim como um regime de normas para diversidade e heterogeneidade dentro e entre as redes, foram consideravelmente reforçados pela invenção da World Wide Web. A rede não surgiu do departamento de defesa americano ou comunidade de pesquisadores mas criada por Tim Berners-Lee, Robert Cailliau, e outros no CERN. (FRANDA, 2001, p. 31)
}

CERN é a sigla para Organização Européia de Pesquisa Nuclear, um dos institutos científicos mais conceituados do mundo. O que não é contestado pela literatura, diferentemente da origem da rede, é que o princípio que gerou a internet está em consonância com o da estratégia militar de manter diferentes unidades de provimento de tropas interligadas. Se uma fosse destruída pelo inimigo, outra poderia desenvolver as mesmas atividades da primeira (CASTELLS, 2003). Seu funcionamento é análogo ao das ligações neurais do cérebro humano. Algumas áreas do cérebro, sob circunstâncias específicas, podem simular a atividade de partes que venham a sofrer lesões (DAMÁSIO, 1996), mostrando uma dinâmica muito parecida com a estratégia militar na qual se baseia a internet. Por esse motivo, a internet é reconhecida como uma rede neural, com processamento e arquivamento descentralizado, mas que possui uma representação na malha de conexões entre os diferentes terminais (nós) de sua rede (CASTELLS, 2003).

Por ter sua representação no conjunto da malha, e não na individualidade dos pontos de acesso, a rede passa uma impressão de homogeneidade para quem nela se conecta. Tal qual percebem Armand e Michèle Mattelart, "a rede serve para fazer esquecer uma sociedade profundamente segregada e para dela propor uma visão harmônica" (MATTELART; MATTELART, 1999, p. 160). Apesar dos pontos de acesso à malha informacional encontrarem sítios em regiões com diferentes peculiaridades e culturas, há a constância de um padrão a ser seguido e compreendido por todos. Essa idéia de integração de diferentes culturas obedece a regras específicas de uma necessidade de comunicação oriunda da dinâmica do sistema capitalista. A intensificação das pesquisas em TI na busca pelo aumento da produtividade e da eficiência comunicacional segue os ideais de um mercado mediado pelas mínimas unidades do sistema (organizações e indivíduos). Em uma escala macroscópica, os 
agentes sociais deixam de ser, diretamente, os homens, dando lugar a instituições diversas, tais quais empresas e nações - que ainda assim são representadas por indivíduos (BAUMAN, 1999). Apesar da participação dos agentes sociais aferirem uma manutenção proveitosa ao status do sistema, contribuindo para a continuação de sua existência (BUCKLEY, 1971), o principal intento do indivíduo ou das entidades sociais em interação com os mercados é a obtenção do lucro (CASTELLS, 1999). Segundo Castells (1999):

\footnotetext{
Empresas e nações (...) são os verdadeiros agentes do crescimento econômico. Não buscam tecnologia pela própria tecnologia ou aumento de produtividade para a melhora da humanidade. Comportam-se em um determinado contexto histórico, conforme as regras de um sistema econômico (o capitalismo informacional, como proposto anteriormente), (...) Assim, as empresas estarão motivadas não pela produtividade, e sim pela lucratividade, para a qual a produtividade e a tecnologia podem ser meios importantes mas, com certeza, não os únicos. (...) A lucratividade e a competitividade são os verdadeiros determinantes da inovação tecnológica e do crescimento da produtividade. (CASTELLS, 1999, p. 101)
}

Esta ação humana na busca do lucro, respeitando a uma lógica típica do capitalismo, acaba por impulsionar todo o desenvolvimento tecnológico que interage com o sistema e nutre suas necessidades de aumento da eficiência comunicacional e da produtividade - alavancando exponencialmente os lucros tão almejados pelos indivíduos e suas instituições capitalistas (DANTAS, 2002).

Definitivamente, as novas tecnologias de informação acabaram por redefinir a estrutura interna do sistema, no que tange aos aspectos produtivos e culturais. Um bom espelho do que trata a nova economia informacional está na constatação de Castells (1999):

Minha tese é de que o surgimento da economia informacional caracteriza-se pelo desenvolvimento de uma nova lógica organizacional que está relacionada com o processo atual de transformação tecnológica, mas não depende dele. São a convergência e a interação entre um novo paradigma tecnológico e uma nova lógica organizacional que constituem o fundamento histórico de economia informacional. (CASTELLS, 1999, p. 174) 


\subsection{Apresentação dos Clusters de Tecnologia de Informação Abordados}

Antes mesmo da invenção do transistor em 1946 pela Bell Labs (CHANDLER; CORTADA, 2003), uma região surgia como um importante marco referencial para a emergente indústria da recente "Tecnologia da Informação" (ou simplesmente TI). O Vale do Silício californiano, apelido concedido ao maior cluster de TI do mundo, com a maior parte de sua extensão situada no condado de Santa Clara, tem como pedra fundamental a fundação da Hewlett-Packard em Palo Alto, em janeiro de 1939 (LÉCUYER, 2006). Dois jovens estudantes de Stanford montaram em uma garagem, patrocinados pelo reitor da universidade, uma micro-empresa de engenhocas eletrônicas que iniciaria a tendência de empreendedorismo da região e criaria o "mito da garagem" - idéia fundamentada no sucesso econômico de vários empreendimentos que começaram com pouco ou nenhum capital nas residências de estudantes universitários (MALONE, 2007).

Algumas das regiões de maior sucesso econômico no desenvolvimento de TI se iniciaram por empreendimentos pequenos, liderados por jovens oriundos de universidades e centros de pesquisa, em busca de consolidarem seus próprios negócios. Outros clusters, tais como os casos nacionais, formaram-se em torno de grandes empresas já instaladas em suas regiões, numa rede de interações que privilegia a posição dos agentes centrais do sistema produtivo regional. As empresas menores acabam dependentes das maiores, que lideram o cenário produtivo, desequilibrando as relações existentes.

A seguir, discorre-se uma breve apresentação de cada um dos clusters abordados. A bibliografia completa sobre os mesmos, no intuito de responder às questões de pesquisa elencadas no roteiro do Apêndice A, será apresentada no texto final da pesquisa.

\subsubsection{Vale do Silício}

O Vale de Santa Clara é seguramente um dos maiores fenômenos da história entre os arranjos produtivos regionais, sendo considerado indispensável para a justificativa do crescimento tecnológico que levou ao informacionalismo (fase informacional do capitalismo). Autores como Castells (1999) e Saxenian (1994) definem o modelo de relações de produção estabelecido no Vale do Silício californiano como oriundo de uma série de mudanças culturais intimamente ligadas ao advento da informática. O arranjo produtivo identificado naquela região é oriundo de uma flexibilidade organizacional ensejada pela revolução cultural dos 
anos sessenta, sob o ideal libertário da descentralização e delegação dos poderes (SAXBY, 1990).

O negócio de circuitos integrados se intensificou de maneira ímpar no Vale de Santa Clara a partir do final da década de 60 , com extensão sobre a primeira metade da década de 70. Segundo Lécuyer (2006), os empregos na área de semicondutores na região cresceram dos 6 mil de 1966 para 19 mil em 1975 (LÉCUYER, 2006, p. 253). O apelido "Silicon Valley" dado ao Vale de Santa Clara ficou comum a partir de 1971, com a publicação de vários artigos naquele ano sobre a emergência da região como um modelo de excelência na tecnologia de informação. A explicação mais comum para o fenômeno, confirmada por autores como Saxenian (1994) e Lécuyer (2006), foi o surto de empreendimento observado na região, que longe de se extinguir durante a fase de implantação das primeiras empresas, manteve-se por muitos anos. Esse primeiro movimento empreendedor tornou-se parte da cultura regional. Há a nítida impressão de que todos querem ser donos de suas próprias empresas no Vale do Silício, tentando repetir o sucesso de empreendimentos como a Apple Computers, ou as empresas de desenvolvimento de softwares e sistemas operacionais como a Microsoft e, mais recentemente, a gigante Google.

O crescimento dos mercados de produtos de informática em todo o mundo na década de 70 levou a região à condição de fornecedora mundial de circuitos integrados, processadores e, mais adiante, softwares. O esquema produtivo encontrado no Vale de Santa Clara privilegiava a dinâmica acentuada do mercado de tecnologia da informação, dotado de uma flexibilidade que contrastava com as regiões concorrentes, nos Estados Unidos (o caso da Rota 128) ou no mundo (SAXENIAN, 1994). Engenheiros de renome, tanto os dissidentes de empresas do setor de semicondutores americano quanto de todo o resto do mundo, passaram a investir suas economias em empreendimentos no Vale do Silício, gerando muitos casos de sucesso. Foi o caso da AMD, criada pelo ex-empregado da Fairchild, Jerry Sanders. A AMD passou a produzir sistemas de memória que logo foram incorporados à maioria dos produtos dedicados ao consumidor final nas décadas de 80 e 90 (MALONE, 2007).

Outras empresas como a IBM, gigantes do ramo de informática, abriram suas unidades na região visando ao aproveitamento da excelência técnica que o ambiente proporcionava. A região se beneficiava da proximidade com Stanford, entre outras universidades locais, tidas como os novos celeiros de talentos da segunda metade do século XX e provedoras de pesquisas indispensáveis para o setor. A proximidade entre universidades e empresas não se deu apenas no âmbito geográfico. As empresas passaram a estabelecer convênios com as universidades para desenvolvimento de inovações e capital humano. Entretanto, não foram 
apenas as mentes treinadas nas universidades da região que fizeram do Vale do Silício um cluster de excelência. As empresas de Santa Clara se beneficiaram de outro fenômeno que, apesar de incentivado pela política americana de atração de novos talentos para as universidades nacionais, tornou-se acima das expectativas regionais: a imigração de talentos do mundo todo para o trabalho nas empresas de alta tecnologia da região. Um dos países que mais contribuíram para este fenômeno imigratório foi a Índia. A este fenômeno, Saxenian (1994) deu o nome de Brain Drain.

A dimensão do Brain Drain para a região do Vale do Silício é explicitada por Saxenian (1994), onde se mostra que um terço dos engenheiros empregados em empresas da região era de origem estrangeira em 1990. Por conta do Brain Drain, um quarto da população local era estrangeiro em 1990. Para se ter uma idéia dos impactos sócio-culturais regionais deste fenômeno imigratório, entre 1975 e 1990 as empresas de tecnologia do Vale do Silício abriram cerca de 150 mil novas vagas - tendo como estimativa que $40 \%$ delas tenham sido ocupadas por profissionais estrangeiros. Isso elevou a população local nascida no exterior de pouco mais de 170 mil para 350 mil habitantes (SAXENIAN, 1994).

O pioneirismo do Vale do Silício não ocorreu apenas no âmbito do desenvolvimento de novas tecnologias. O cluster inaugurou um tipo de configuração de arranjo produtivo sob um nível de cooperação entre as companhias instaladas que remetiam ao alinhamento produtivo das empresas japonesas, ainda na década de 1970. Este tipo de relação não aconteceu do acaso. Na verdade tem sua origem no tipo de empreendedorismo que permitiu que a Hewlett-Packard alcançasse êxito em seu segmento, muito ligado ao senso de comunidade.

De fato, como ressalta Saxenian (1994), ser engenheiro ou pesquisador em Tecnologia da Informação entre 1970 e 1990 no Vale do Silício significava, necessariamente, conhecer uma boa quantidade dos demais profissionais. Muitos estudaram ou trabalharam juntos em algum momento. A região estabeleceu um tipo de comunidade de técnicos que permitiu o desprendimento necessário à transferência de conhecimento tácito em diversos níveis, em todas as posições das corporações. A abundância de informação, dada pelas conexões não formais estabelecidas, levou à transparência das relações de mercado e gerou oportunidades àqueles que detinham qualquer possibilidade de se estabelecer enquanto empresários. E os empreendedores, na maioria das vezes, se conheciam - e outras vezes eram até mesmo amigos. Como aponta Bylinsky (1976), "muitos dos executivos do Vale do Silício se conheceram como estudantes em Stanford ou como participantes de negócios locais ou 
assuntos políticos. A relativa proximidade entre as companhias faz com que as associações se tornem fáceis" (BYLINSKY, 1976, p. 67).

As relações entre os trabalhadores e empreendedores do cluster iam muito além do horário de expediente. Como sinaliza Wolfe (1983):

\footnotetext{
Todo ano é eleito algum lugar, o Wagon Wheel, o Chez Yvonne, o Rickey's, o Roundhouse, para onde os membros dessa esotérica fraternidade, os jovens homens e mulheres da indústria de semicondutores, se encaminham após o trabalho para beber, confraternizar e trocar histórias (...) (WOLFE, 1983, p. 362 apud Saxenian, 1994, p. 33)
}

Segundo Castells (1999), muito mais foi feito pela evolução da Tecnologia de Informação em reuniões noturnas nos bares e restaurantes do Vale de Santa Clara do que na maioria dos seminários de Stanford. Esse modelo de relações informais entre os agentes de inovação do cluster garantiu que as informações se difundissem em maior intensidade e velocidade, fazendo com que o tempo de acesso a informações preciosas sobre mercado e tecnologia se reduzisse do intervalo entre publicações dos periódicos especializados para o período entre expedientes. Como afirma Saxenian (1994), “a socialização informal oriunda dessas relações quase familiares deu suporte a práticas de colaboração e compartilhamento de informações entre os produtores locais" (SAXENIAN, 1994, p. 32).

Outra característica marcante do cluster foi a constante mudança de empregos dos trabalhadores da região. Movidos pela possibilidade de novos desafios e crescimento dos ganhos, os empregados do Vale do Silício saltavam de um emprego para outro na mesma velocidade do mercado de tecnologia. Segundo um dos entrevistados por Saxenian (1994), "as pessoas mudam de emprego por aqui sem mudar as vagas de estacionamento" (SAXENIAN, 1994, p. 35). Uma das vantagens de coabitar o espaço de vários empreendimentos do mesmo segmento é de mudar de emprego sem ter que mudar de casa. Isso favorece a extensão dos vínculos pessoais entre os trabalhadores, uma vez que apesar da mudança de um emprego para outro, ainda mantêm as relações informais em âmbito local.

A lógica instalada no Vale do Silício transformou os padrões éticos da cultura vigente, transferindo a questão da lealdade frente às companhias para a lealdade com a rede de relacionamentos estabelecidos. Essa mudança, além de corroborar com o fluxo migratório de funcionários entre empresas do cluster, garantiu com que as relações pessoais entre empreendedores, trabalhadores e pesquisadores ganhassem importância frente às relações 
comerciais estabelecidas, o que garantia o sentimento de "comunidade". As pessoas, dessa forma, sentem que não trabalham para uma companhia, mas para o Vale do Silício (SAXENIAN, 1994).

A idéia de comunidade se reforçou na emergência de uma cultura típica da região, voltada para a valorização do empreendedorismo. Como toda cultura, a do Vale do Silício também tem seus heróis, verdadeiros mitos que se baseiam em estratégias emblemáticas de sucesso em empreender. Sejam eles Robert Noyce (Intel), Steven Jobs (Apple) ou Bill Gates (Microsoft), cada qual vigorou por um determinado período como exemplo a ser seguido por inúmeros outros empreendedores, que deixavam suas posições nas empresas já instaladas para abrirem seus próprios negócios.

Apesar dos empreendimentos da região terem se beneficiado da presença de duas universidades de expressão em desenvolvimento de recursos humanos especializados, Stanford e Berkeley, pode-se dizer que as mesmas também se beneficiaram do crescimento econômico (e de necessidade de mais e melhores recursos humanos) que o cluster propiciou. Na verdade, o sistema de faculdades comunitárias da Califórnia sofreu um salto evolutivo nas décadas de 1970 e 1980 como nunca antes na história, impulsionado pelo número de vagas disponíveis para especialistas em eletrônica e comunicações surgidas das empresas de TI que se instalavam na região. Não era raro quando os estudantes dessas instituições passavam, antes mesmo de sair da faculdade, a competir com as empresas já instaladas, seguindo ícones do empreendedorismo como Gates e Jobs, que iniciaram suas atividades antes mesmo de completarem os estudos.

Havia uma região americana que se portava como concorrente direta do Vale do Silício californiano, a Rota 128 em Massachusetts. Na verdade, essa região foi a primeira a despontar como pólo de TI, beneficiada pela presença do MIT e do investimento massivo do governo entre os anos 1930 e 1960. A cultura organizacional cunhada em Massachusetts era baseada em elementos mais tradicionais, como independência e hierarquia (SAXENIAN, 1994). O empreendedorismo em Boston era um tipo de passo herege que só deveria ser tomado se não houvesse risco operacional elevado. Já na cultura organizacional do Vale do Silício, a aceitação do risco era muito maior, e ao contrário do que acontecia entre os empreendedores da Rota 128, servia de estímulo para o surgimento de novos negócios, seguindo a máxima de quanto maior o risco, maior a recompensa.

O modelo de arranjo produtivo baseado nas relações entre indivíduos sob o manto de uma cultura voltada para empreendedorismo e a cooperação entre empresas não seria, nem com muito esforço, a única condição para o sucesso do Vale do Silício. Havia uma coisa na 
Rota 128 que o Vale de Santa Clara teve que buscar em outro canto do país: investimento. O capital que alavancaria o desenvolvimento das empresas do pólo tecnológico dependeu da consolidação de uma modalidade de investimento até então considerada heterodoxa pela maioria dos detentores de recursos, praticamente a fundo perdido. Tratava-se do chamado "capital de risco", uma espécie de aposta dos investidores nas tecnologias desenvolvidas pelos empreendedores do cluster. Discorrendo sobre o fluxo financeiro para fomento das empresas de tecnologia do Vale de Santa Clara, Stiglitz (2003) descreve:

\begin{abstract}
Embora divergissem em muitos aspectos, Nova York e o Vale do Silício eram dependentes um do outro e sabiam disso. Novas idéias exigiam capital para que fossem realizadas e o Vale do Silício havia desenvolvido uma nova instituição - a empresa de capital de risco - para fazer exatamente isso. As empresas de capital de risco só poderiam financiar novos investimentos se pudessem tirar proveito dos sucessos de empreendimentos anteriores. (...) $\grave{A}$ medida que os novos empreendimentos surgiam, as grandes instituições de investimento vendiam seus títulos mobiliários para o público. (...) Nos anos 90, a capacidade dos Estados Unidos para financiar a inovação financeira causou inveja no mundo. (STIGLITZ, 2003, p. 165)
\end{abstract}

Não fosse o surgimento das empresas de capital de risco, financiadoras de empresas inovadoras, não se ouviria falar do Vale do Silício, nem de qualquer outro cluster tecnológico de relevância. Estas empresas servem, na verdade, como financiadoras de diversos empreendimentos inovadores, constituindo-se em formatos variados (PAVANI, 2003). Como toda grande inovação que traga consigo mudanças paradigmáticas no ambiente industrial, foi necessário aporte de capital, oriundo de outros segmentos e mediados pelo mercado financeiro, para que houvesse recursos que possibilitassem a revolução produtiva proporcionada pelo Vale de Santa Clara.

O fluxo financeiro estabelecido pelas empresas de capital de risco, entre outros provedores como bancos e, não menos importante, o governo americano, não foi o principal responsável pelo desempenho do cluster de Santa Clara. Empresas que financiam empreendimentos inovadores se pautam nas expectativas de retorno, assim como nos tipos de arranjos administrativos e produtivos que os empreendimentos visam estabelecer. Como Epstein, Davila e Shelton (2006), "transformar boas idéias em inovações sólidas exige que as idéias sejam transformadas de esqueletos em possibilidades em algo em que os investidores consigam enxergar valor" (EPSTEIN; DAVILA; SHELDON, 2006, p. 146). Por contar com 
uma rede muito bem articulada de agentes de inovação, os projetos do cluster californiano prometiam arranjos muito bem constituídos que incluíam recursos humanos formados em universidades de renome aliados a uma estrutura prévia de institutos de pesquisa que soavam como credibilidade aos investidores. E de fato, muitos foram os negócios bem sucedidos, em uma escala que modificou todo o paradigma industrial de sua época.

Somente a presença de investidores interessados e centros de excelência em pesquisa já garantiriam êxito em estabelecer um modelo de prospecção de inovação. Mas quando somada a presença de recursos humanos altamente especializados, vindos das melhores turmas de engenharia e ciências correlatas de todo o mundo, especialmente da Ásia e de todos os cantos dos Estados Unidos e Europa, o diferencial estava consolidado. Esses elementos fizeram possível a emergência de uma cultura típica da região, que privilegia o empreendedorismo e a cooperação.

\subsubsection{Bangalore}

Bangalore é a maior cidade e a capital do estado de Karnataka, na Índia. Possui cerca de 6 milhões de habitantes e é tida como o centro da indústria de alta tecnologia da Índia. Situam-se hoje em Bangalore mais de 1500 empresas e instituições de pesquisa tecnológica (ASHWANI; VIJAYABASKAT, 2005), o que lhe confere um caráter diferenciado entre as demais cidades do país. Sua origem é produto do investimento da Grã-Bretanha em uma espécie de "resort de descanso para os oficiais militares e servidores civis" (COOKE, 2005, p. 53) britânicos nos tempos em que a Índia era uma colônia, estabelecendo a cidade a cerca de 3000 pés acima do nível do mar. Segundo Cooke (2005):

\footnotetext{
A administração britânica estabeleceu lá o Instituto Indiano de Ciência, especializado inicialmente em engenharia e física. Foi o embrião da Universidade de Bangalore, possuindo catorze faculdades de engenharia, incluindo hoje em dia a engenharia de software e engenharia de computação. Há também numerosas instalações estatais de tecnologia de defesa e telecomunicações, atraídas pelo capital humano e distância das fronteiras. (COOKE, 2005, p. 53).
}

Os engenheiros e pesquisadores que outrora saíram da Índia em busca de condições de excelência para seu trabalho nos Estados Unidos, começaram a retornar para seu país de origem com o intuito de estabelecer novas KBFs. A região de Bangalore, por ter condições de 
suprir as necessidades de um novo Sistema Regional de Inovação (universidades, centros de pesquisa e talentos humanos especializados disponíveis), tornou-se um cluster de excelência na Ásia em tecnologia de informação. O processo de empreendedorismo iniciado pelo retorno dos antigos trabalhadores do Vale do Silício foi primordial para a constituição de um parque tecnológico de informática, especialmente na área de desenvolvimento de softwares. Como analisado em Saxenian (2006), o Brain Drain de outrora deu origem ao movimento de Brain Circulation, conceito delimitado pela autora como "o retorno para casa [dos profissionais de TI] para estabelecer relações de negócios ou iniciar novas companhias enquanto mantêm seus laços sociais e profissionais com os Estados Unidos” (SAXENIAN, 2006, p. 36).

O caso do Brain Circulation indiano retoma a questão das conexões para transferência de conhecimento tácito entre diferentes Sistemas Regionais de Inovação. De certa forma, vem como solução da problemática enunciada por Todaro (1985), onde se tinha a idéia de que a migração de talentos de regiões mais pobres para aquelas que oferecessem melhores condições era permanente. Traz consigo uma imensa gama de questões sobre a transnacionalidade dos recursos, além da apropriação informal de conhecimentos gerados em regiões de maior desenvolvimento tecnológico. O retorno de profissionais aos seus países de origem após anos de estudo ou trabalho em regiões de excelência tecnológica é uma espécie de recompensa pela cessão das relações dos mesmos durante um largo período com os Sistemas Regionais de Inovação originais.

Entretanto, como salienta Saxenian (2006), o fenômeno do Brain Circulation não se restringe ao retorno dos outrora empregados de KBFs como empreendedores aos seus países de origem. Não são raros os engenheiros indianos, outrora residentes nos Estados Unidos, que retornam à Ásia para estabelecer parcerias em regiões diversas, como a China, levados através de convites de parceiros dos tempos de América, formando uma conexão de, segundo o exemplo, três vértices, entre as regiões do Vale do Silício, Bangalore e Xangai (SAXENIAN, 2006). Esses novos argonautas, caracterizados em Saxenian (2006), trazem consigo conhecimento tácito de vital importância para os Sistemas de Inovação locais, agregando vantagens competitivas às empresas de seus clusters de destino.

Percebe-se uma integração de nível internacional entre as empresas da região de Bangalore, o que favorece sua atuação no mercado global. O setor de softwares é particularmente significativo dentre as indústrias locais do segmento de TI. Apesar disso, a indústria de software indiana não se localiza apenas em Bangalore, mas em "regiões como Bombaim, Pune, Madras e Hyderabad" (BRESNAHAN; GAMBARDELLA, p. 104, 2004). Dessa forma, é possível afirmar que há um Sistema Nacional de Inovação contribuindo para a 
manutenção dos parâmetros regionais de Bangalore, seja no que tange ao intercâmbio de conhecimentos como no que se refere à competitividade interna, essencial para impulsionar processos de inovação. Com exceção da região de Nova Deli, há vários clusters tecnológicos citáveis na parte norte e leste do país, sem ainda haver estudos contundentes que comprovem os efeitos sociais e econômicos das aglomerações de empresas de um mesmo setor nestas regiões.

Além do fenômeno de Brain Circulation, outros fatores contribuíram para a formação de um cluster de alta tecnologia em Bangalore. Um deles é discutido por Ács, Groot e Nijkamp (2002), a necessidade dos países em desenvolvimento de fomentarem atividades que sejam competitivas sob uma realidade que foge aos primeiros processos de industrialização. Os efeitos sobre a competitividade de uma industrialização tardia devem ser amenizados pela opção de concorrência em campos estratégicos para os negócios do informacionalismo, ou seja, o investimento em áreas de alta tecnologia que ofereçam compensações à defasagem ocorrida desde o processo de industrialização. É como se através do setor de serviços de alta tecnologia fosse possível suplantar os anos de desatualização tecnológica da indústria nacional, oferecendo ao mercado internacional um serviço de ponta a custos demasiadamente inferiores do que os praticados nos países do eixo do sistema capitalista (ÁCS; GROOT; NIJKAMP, 2002). O principal ativo das indústrias de tecnologia, o talento humano, é aquele que a região de Bangalore tem de sobra (SAXENIAN, 2006). E o segmento de TI que mais se encaixa com essa característica é o de software, setor de especialização do cluster.

O setor de softwares foi valorizado em toda a Índia através da iniciativa que estabeleceu o conceito de STP (Software Technology Park) em escala nacional, instalando pólos em cidades como Trivandrum, Mumbai, Pune, Calcutta, Gandhinagar, entre outras. Segundo Yue et al. (2001):

A STPI (Software Technology Parks of India), uma organização autônoma, foi estabelecida pelo Departamento de Eletrônica do Governo da Índia para promover o desenvolvimento dos empreendedores operando sob o esquema do STP. Por esse esquema, os empreendedores são elegíveis ao aval de benefícios que incluem: importações completamente livre de impostos; (...) isenção de imposto de renda por um período de dez anos; (...) (YUE et al., 2001, p. 13)

O governo indiano incentivou, através de medidas como o STPI, a instalação de novos empreendimentos, liderados por empreendedores nativos com recursos direcionados de fontes de diversas partes do mundo, em especial do mercado financeiro americano e europeu. Não 
somente os empreendedores nativos, mas também as grande empresas multinacionais, acabaram por se beneficiar dos intentos governamentais, principalmente no que tange ao melhoramento da estrutura organizacional voltado para suprir as necessidades da indústria de softwares. Mas apesar de conhecedor das particularidades que alavancariam as oportunidades de negócios em sua terra natal, os empreendedores indianos ainda tinham os olhos voltados para um esquema de desenvolvimento típico do ocidente, em especial dos clusters americanos de TI.

A economia de Bangalore, de um modo sistêmico, está muito mais integrada à economia internacional do que a de seu próprio país (ASHWANI; VIJAYABASKAT, 2005). As relações estabelecidas pelas pequenas e médias empresas da região rumam em direção ao estrangeiro, muito mais do que ao interior da própria nação. Isso não quer dizer que não haja comunicação ou mesmo parcerias firmadas com outras instituições nacionais, mas significa que há muito mais proximidade do mercado global do que do resto do país. Além dos próprios fundadores das empresas de tecnologia da região possuírem laços estreitos com o meio externo (em especial com os Estados Unidos e China), tendo estudado em centros de excelência do exterior, muitas das empresas localizadas em Bangalore possuem sócios e parceiros localizados além da fronteira da Índia (SAXENIAN, 2006). Essa característica da região foi observada por Mehra (2003) ao analisar os Sistemas Regionais de Inovação na Índia. O modelo produtivo da região de Bangalore se assemelha em muito ao do Vale do Silício californiano, principalmente por conta do tipo de relações, muito próximas da informalidade, realizadas entre seus agentes regionais e internacionais.

Uma das empresas estabelecidas na região é a multinacional de semicondutores Texas Instruments. Segundo Mansell (2007), "nos anos 80 a Texas Instruments era uma companhia global com presença asiática no Japão, Taiwan, Singapura e Malásia” (MANSELL, 2007, p.91). Em 1986, quando iniciou suas operações na Índia, a empresa empregava apenas 17 funcionários de alta especialização entre engenheiros e programadores. O vultoso crescimento das operações na Ásia e as boas condições oferecidas pela região de Bangalore fizeram com que a Texas Instruments Índia expandisse seu número de empregados para 1300 até 2005 (MANSELL, 2007), cerca de 4\% de toda a força de trabalho da companhia no mundo todo. Assim como a Texas Instruments, outras empresas de grande porte se instalaram na região, a reboque de uma tendência que começava a acontecer com o retorno dos outrora estudantes e trabalhadores indianos em outros pólos tecnológicos do mundo, em especial do Vale do Silício. As empresas multinacionais se aproveitavam das boas condições que a região oferecia aos investimentos em tecnologia, em especial ao baixo custo dos recursos humanos em 
pesquisa e desenvolvimento de produtos e processos, cada vez mais especializados e de maior qualidade. Para se ter uma idéia, o salário médio anual de um profissional de desenvolvimento em ciência e tecnologia em Bangalore flutua entre 4 mil e 6 mil dólares (COOKE, 2005), enquanto nos Estados Unidos essa quantia média pode chegar a mais de 40 mil dólares, dependendo do cluster. Isso caracteriza "uma vantagem competitiva significativa" (COOKE, 2005, p. 54) para Bangalore. Entre as empresas multinacionais instaladas no cluster, podem ser citadas pela relevância os Centros de Pesquisa e Desenvolvimento das seguintes companhias:

- Texas Instrument, instalada em 1986, possui mais de 1000 engenheiros contratados e cerca de 200 associados para negócios. É a maior instalação da companhia na Ásia, tendo desenvolvido mais de 225 patentes nos últimos 15 anos (BASANT, 2008);

- Intel, instalada em 1998, inicialmente com apenas 20 engenheiros, hoje emprega mais de 1400 engenheiros em Pesquisa e Desenvolvimento. A Intel terminou em 2009 o seu segundo centro de pesquisas em Bangalore, e pretende incorporar até o final de 2010 mais 1000 engenheiros ao seu quadro local de empregados (BASANT, 2008);

- General Electric, instalada em 2000 e ampliada em 2001. O Centro de P\&D da GE em Bangalore possui cerca de 1800 empregados entre cientistas e engenheiros, todos envolvidos diretamente com pesquisa e desenvolvimento. Cerca de $20 \%$ dos trabalhadores da unidade possuem experiência global. A GE adentrou o cluster estabelecendo relações com a Infosys e Wipro, gigantes indianas do segmento de tecnologia de informação, com contratos para desenvolvimento de produtos na área de equipamentos médicos (BASANT, 2008);

- IBM, em atividade na Índia desde a década de 1960, finalizou suas atividades no país no final dos anos 1970 por conta das restrições legislativas às atividades de multinacionais no país. Voltou ao país em 1992 através de uma joint venture com a Tata Consultancy Services. A partir de 1997 instalou sua base de serviços globais em Bangalore. Hoje, emprega cerca de 3100 engenheiros, sendo que 400 profissionais estão alocados em seu Centro de Testes de Software (BASANT, 2008);

- Oracle, formou sua subsidiária na região de Bangalore em 1993, e a maior parte de seus 3200 funcionários indianos alocados em pesquisa e desenvolvimento de produtos estão concentrados na unidade do cluster. A companhia subsidia $75 \%$ do curso de Mestrado de seus funcionários indianos em universidades americanas, para que haja maior alinhamento às premissas culturais envolvidas nas ações da empresa, ação que aumenta a experiência global de seu quadro de recursos humanos (BASANT, 2008); 
- Philips, instalou seu Campus de Inovação em Bangalore em 1996, possuindo hoje cerca de 2000 funcionários; entre muitos outros centros de desenvolvimento de companhias multinacionais.

As grandes empresas instaladas na região passaram a dividir espaço com os novos empreendimentos daqueles engenheiros que, retornando de experiências internacionais, traziam consigo elementos culturais atrelados à dinâmica do empreendedorismo. Essa modificação nos padrões organizacionais de Bangalore trouxe a atenção de pesquisadores que passaram a se questionar sobre a existência de uma cultura típica da região orientando as modificações produtivas ou se nada mais era do que um simulacro cultural do que era vivenciado em outros clusters do mundo. Segundo Srinivas (2004):

\footnotetext{
Embora a indústria indiana de software represente apenas um por cento da indústria de software global, ela é um estudo de caso de uma indústria crescendo para atingir um padrão internacional e sendo vista como um modelo a ser copiado por outros países em desenvolvimento. O crescimento da indústria indiana de software (...) levanta algumas questões interessantes acerca da natureza dos negócios na Índia moderna: há algo de indiano nos negócios da Índia? (SRINIVAS, 2004, p. 128)
}

Seria possível dizer que os indianos que retornavam à Bangalore trazendo seu ímpeto empreendedor estariam deformando a cultura produtiva local com a inserção de novos valores que transformavam a tradição dos negócios indianos em um desdobramento asséptico da cultura do meio - aquela ligada à lógica de acumulação do capital informacional? De fato, toda revolução nos padrões produtivos transforma a cultura das regiões mais afetadas pelas mudanças de valores. Entretanto, pelo menos no que tange aos desdobramentos sociais, podese dizer que os novos valores combinados à cultura local, relacionados com a produção econômica, muito pouco contribuem para a equidade, devendo essa transição estar acompanhada de políticas públicas eficientes. E talvez no caso da Índia, a própria noção de equidade esteja em desacordo com as tradições locais. Enquanto Saxenian (2006) defende que as mudanças econômicas têm que ser acompanhadas de mudanças políticas, refletindo as possibilidades de alteração no padrão cultural local, ainda são predominantes na Índia (e em muitos países da Ásia) elementos culturais seculares que sedimentam uma estrutura social que não permite a incorporação de valores igualitários. Embora a mudança política acompanhe o cenário econômico (e os ditames do capital que move o informacionalismo), não o faz ao mesmo passo das mudanças no âmbito produtivo, o que deixa mais evidente a falta de equidade social. Ainda que a política institua novas leis, conforme padrões ditados pelo ritmo 
desenvolvimentista vindo do exterior, essas leis não são cumpridas, nem mesmo fiscalizadas com rigor (KAMDAR, 2008).

Para se ter uma idéia da relevância do cluster de Bangalore em relação ao resto da Índia, 55\% das empresas de software, nacionais ou internacionais, instalou-se na região (SRINIVAS, 2004). A região de Bangalore empregava, até 2005, a maioria dos engenheiros e pesquisadores em tecnologia de informação do país (SRINIVAS, 2004), e tornou-se referência para todo o mundo em produção tecnológica. Entretanto, questiona-se sobre os efeitos sociais desse desenvolvimento. Partindo-se da análise da estrutura necessária ao suporte desse nível de crescimento, há uma tendência de não distribuição dos recursos auferidos com o desenvolvimento, pois segundo Srinivas (2004), “a vida cotidiana em Bangalore é miserável, com apagões constantes, engarrafamentos de trânsito e colapsos no sistema de fornecimento de água" (SRINIVAS, 2004, p. 128). Essa posição é corroborada pela percepção de Cooke (2005), quando afirma que "existe um problema infra-estrutural, no qual o fornecimento de energia não está adequado para atingir as crescentes demandas do setor de software" (COOKE, 2005, p. 54).

Para que haja desenvolvimento sistêmico, ou seja, que possa ser mantido por um longo período sem preocupações com escassez de recursos, é necessário que haja a distribuição igualitária que equacionem ofertas e demandas de recursos. Se a infra-estrutura não acompanhar o crescimento econômico da região e, para garantia da equidade social, for direcionada para todas as classes de indivíduos que coabitem o mesmo espaço, além do aumento de tensões sócio-econômicas de todos os tipos possíveis, é previsível no médio prazo o colapso do sistema.

Corroborando com as considerações de Srinivas (2004), Kamdar (2008) transcreve a experiência de uma engenheira americana que visitou Bangalore em 2006:

Da primeira vez que vim aqui eles me puseram no Leela, o hotel mais elegante que já vi. Tem sete estrelas. Eu nem sabia que havia hotéis de sete estrelas. Da segunda vez fiquei no royal Orchid, onde descortinei uma típica paisagem indiana: virei a cabeça para um lado e vi um campo de golfe com um lindo gramado, e bem próximo dele um prédio da IBM que poderia perfeitamente estar nos EUA. Então virei a cabeça para o outro lado e vi essas barracas (...). Havia criancinhas brincando na sujeira. (KAMDAR, 2008, p. 293)

Além da miséria que margeia as novas estruturas produtivas de Bangalore, uma das leis mais ignoradas é a que pró́be o trabalho infantil. Cerca de $10 \%$ da força produtiva 
indiana em atividade é composta de crianças (KAMDAR, 2008). Apesar da proximidade do modelo de relações produtivas observada no cluster californiano, Bangalore está muito distante de garantir as condições de vida que o Vale de Santa Clara garante aos seus moradores, por motivos que estão relacionados mais à adesão tardia ao modelo capitalista informacional do que à cultura organizacional, a exemplo do que ocorre em muitas outras nações em desenvolvimento (CARDOSO DE MELLO, 1982). De fato, os elementos culturais trazidos pelos engenheiros e empreendedores que voltavam após longos anos trabalhando em países do primeiro mundo não estavam preparados para lidar com a condição de atraso social - no sentido de oferecimento de oportunidades de inclusão aos indivíduos - por não derivarem de uma sociedade que compartilhasse dessas condições.

Ainda que não tenha um histórico de desenvolvimento parecido com o cluster californiano de tecnologia de informação, o cluster indiano possui diversas similitudes culturais com o modelo americano, elementos trazidos pelos empreendedores argonautas (SAXENIAN, 2006). A cultura organizacional de Bangalore também é margeada pelos mitos de seus novos heróis, ao modelo de Bill Gates e Steven Jobs no Vale do Silício. O grande exemplo da região é Narayan Murthy, criador da companhia Infosys, um empreendedor que "é um modelo muito admirado de jovem homem de negócios" (SRINIVAS, 2004, p. 129).

Se por um lado a dinâmica de desenvolvimento de Bangalore pulou estágios essenciais que garantiriam a inclusão de uma fatia maior da população, no tocante à velocidade de aplicação dos investimentos na expansão das empresas encontrou um ritmo até mesmo mais acentuado do que no Vale do Silício. Como afirma Hamm (2007), "no Vale do Silício, os prédios de escritório normalmente surgem um por vez. Em Bangalore, eles surgem em lotes" (HAMM, 2007, p. 12).

Segundo Basant (2008), "Bangalore possui mais de 1500 firmas de tecnologia da informação e muitas outras em outros setores como eletrônica" (BASANT, 2008, p. 150). Ainda em 1996, o Pólo Tecnológico de Software de Bangalore já era responsável por 53\% das exportações de todos os parques tecnológicos da Índia (BALASUBRAMANYAM; BALASUBRAMANYAM, 2002). Segundo Yue et al. (2001), a manutenção da competitividade internacional do cluster de Bangalore se deve a:

- Disponibilidade de profissionais de alta tecnologia;

- Disponibilidade de institutos de pesquisa e laboratórios;

- Centros avançados de produção tecnológica;

- Clima favorável ao longo do ano; e

- Custo de vida mais baixo do que Mumbai e Delhi. 
Os pontos sinalizados por Yue et al.(2001) são congruentes com os argumento dos diversos autores vistos no tópicos 2.1, 2.2 e 2.3 anteriores. Entretanto, outra importante característica é a presença maciça de investidores que possibilitaram a emergência de novas empresas para interagir (concorrencialmente ou cooperativamente) com as grandes instaladas. Esse capital era canalizado pelos empreendedores, engenheiros e cientistas argonautas (SAXENIAN, 2006), captados através dos bons contatos feitos em seu tempo de trabalho em clusters de relevância como o Vale do Silício nas décadas de 1970 a 1990. Além de manterem uma postura mais aberta aos negócios com empresas de capital de risco, buscando fontes de capitalização típicas da cultura dos empreendimentos californianos, os novos argonautas, retornando à sua terra natal, traziam consigo a idéia de captação de recursos nos mercados de capitais de grandes centros financeiros.

Os empreendedores indianos de tecnologia em condição superavitária passaram a criar suas próprias empresas de capital de risco, dependendo menos do capital externo para alavancar empresas nascentes na região. Essas empresas contam com fundos provindos de diversos grupos investidores do mundo, mas possuem a maior parte de sua administração na mão de indianos. Por fim, é possível dizer que as condições de operação do cluster de Bangalore, excluindo-se o contexto social atrelado ao desenvolvimento tardio e descompassado, são bastante similares - respeitadas as proporções e historicidade - àquelas observadas no Vale do Silício californiano, conforme mostra o quadro desenvolvido por Yue et al. (2001): 
Quadro 1

\begin{tabular}{|c|c|c|}
\hline & $\begin{array}{l}\text { Vale do Silício } \\
\text { (Califórnia) }\end{array}$ & Bangalore \\
\hline $\begin{array}{l}\text { Companhias } \\
\text { Âncoras }\end{array}$ & $\begin{array}{l}\text { HP, Fairchild, Sum Micro } \\
\text { Systems }\end{array}$ & $\begin{array}{l}\text { WIPRO, Infosys, } \\
\text { Microland, i-Flex, TCS, } \\
\text { Motorola, Texas } \\
\text { Instruments }\end{array}$ \\
\hline $\begin{array}{l}\text { Centros de } \\
\text { Pesquisa }\end{array}$ & $\begin{array}{l}\text { XEROX, Palo Alto } \\
\text { Research Centre }\end{array}$ & $\begin{array}{l}\text { Indian Space Research } \\
\text { Organisation, National } \\
\text { Aeronautical Laboratory, } \\
\text { Defense Establishment of } \\
\text { Electronic Research }\end{array}$ \\
\hline Universidades & $\begin{array}{l}\text { Stanford, UC Berkeley, } \\
\text { Caltech }\end{array}$ & $\begin{array}{l}\text { Indian Institute of } \\
\text { Science, Indian Institute } \\
\text { of Management, Indian } \\
\text { Institute of Information } \\
\text { Technology } \\
\end{array}$ \\
\hline $\begin{array}{l}\text { Financiadores de } \\
\text { Capital de Risco }\end{array}$ & $\begin{array}{l}\text { Draper, Walden, NICCO, } \\
\text { Kleiner, Perkins }\end{array}$ & $\begin{array}{l}\text { Draper, KITVEN, ICICI } \\
\text { Ventures, Indus Ventures, } \\
\text { CAN Bank, ICF Ventures }\end{array}$ \\
\hline
\end{tabular}

Quadro Comparativo entre o Vale do Silício e Bangalore

Fonte: Yue et al. (2001)

A realidade do cluster de Bangalore está muito mais próxima dos clusters brasileiros abordados do que o caso californiano, por fazer parte de um país em desenvolvimento com características próximas daquelas encontradas no Brasil, principalmente no que tange às desigualdades sociais e ao desenvolvimento capitalista tardio. Entretanto, a cultura indiana é muito diferente da cultura brasileira, ainda muito próxima dos princípios religiosos que constituíram a hierarquia social do país. De certa forma, o Brasil - ao menos a primeira vista - conta com vantagens relacionadas à proximidade de sua cultura aos padrões ocidentais inseridos no contexto de globalização. Todavia, a cultura organizacional brasileira começa ainda a despertar para o empreendedorismo, em uma velocidade muito aquém daquela observada em Bangalore, sob pouca incidência de investimentos externos em capital de risco. A questão do Brain Circulation, ou o retorno dos argonautas à Índia, trouxe modificações essenciais à cultura organizacional ligadas ao empreendedorismo, coisa que ainda não é possível de se ver como uma tendência no Brasil. Os próximos tópicos mostram um pouco da caracterização dos pólos tecnológicos de informação nacionais abordados na pesquisa. 


\subsubsection{Campinas}

A região de Campinas, no interior do Estado de São Paulo, é uma das que mais cresce em todo o Brasil. Seu potencial econômico se iguala ao de muitas capitais do país, em torno de um mercado de dinâmica acentuada (CANO; BRANDÃO, 2002). Campinas possui uma atividade industrial bastante diversificada, não somente concentrada nos ramos de alta tecnologia. Entretanto, seu reconhecimento vem da escolha de sua região por investidores brasileiros e estrangeiros para uma série de empreendimentos de alto nível tecnológico, em específico os ligados à tecnologia da informação. A indústria de microeletrônica, por exemplo, encontrou na região um ambiente favorável ao seu crescimento, tanto pela presença de um pólo universitário muito conceituado (compreendido entre a Universidade Estadual de Campinas - Unicamp - e a PUC Campinas) quanto pela proximidade de centros de excelência em pesquisa de tecnologia da informação, os casos do CPqD, do CTI e do Laboratório Síncrotron.

Grandes empresas de informática se instalaram na região desde a década de 70. São os casos da americana IBM, da Compaq, da Hewlett-Packard, da Texas Instruments e da SCI Systems, o que torna Campinas uma espécie de Vale do Silício "tupiniquim" (CANO; BRANDÃO, 2002). A cidade, observada a tendência de atração de investimentos voltados para a indústria de alta tecnologia, passou a desenhar estratégias que permitissem o desenvolvimento desse talento natural da região. Em 1986 foi instituído, a partir de um projeto de professores da Unicamp, o Parque Tecnológico de Campinas. A administração do parque tecnológico é feita nos dias atuais pela Ciatec, Companhia de Desenvolvimento do Pólo de Alta Tecnologia de Campinas, órgão ligado à Prefeitura Municipal e à Unicamp fundado em 1992.

Campinas possui hoje dois parques tecnológicos administrados pela Ciatec, um na rodovia D. Pedro I e outro próximo, na rodovia Campinas-Mogi Mirim. No Pólo II de Alta Tecnologia, estão localizados o $\mathrm{CPqD}$ e a Hewlett-Packard, entre outras instituições e empresas de alta tecnologia. Além dos parques administrados pela Ciatec, existe o Techno Park, uma iniciativa privada do Grupo DPaschoal no intuito de oferecer um condomínio de empresas de tecnologia sob o compartilhamento de uma das melhores malhas viárias do país.

Segundo Cruz (2008), “o investimento em pesquisa e desenvolvimento na região de Campinas está em R \$ 250 milhões ao ano" (CRUZ, 2008, p. 132). Segundo o autor, o pólo tecnológico da cidade gera cerca de 3 mil empregos diretos, com mais de 100 empresas instaladas, dentro e fora dos limites do parque tecnológico administrado pela Ciatec. 
De acordo com Diniz e Gonçalves (2005):

além das amenidades urbanas, da base econômica e do mercado de trabalho existentes, a atratividade de Campinas pode ser explicada pelo ambiente extremamente favorável à pesquisa, que começou a ser formado a partir da presença de vários centros de pesquisa agrícola e da implantação da Universidade estadual de Campinas (UNICAMP), em 1962. (DINIZ; GONÇALVES, 2005, p. 160)

Na perspectiva de Santos (2005), “a dinâmica sócio-espacial de Campinas relaciona-se subordinadamente aos processos mais gerais de desconcentração das atividades produtivas da região metropolitana de São Paulo" (SANTOS, 2005, p. 206), o que significa dizer que a presença de empresas de tecnologia na região não se justifica apenas pela existência de condições que viabilizem a consolidação de um Sistema Regional de Inovação, mas também se apóia na lógica de descentralização do poder produtivo da capital. Campinas é uma opção acessível aos empreendimentos que voltam os seus negócios para o mercado nacional e internacional, tendo a metrópole paulistana como canalizadora das relações necessárias para a atuação nesses âmbitos. Uma vez que os recursos da capital são escassos e caros, a região de Campinas é uma opção de alto nível que, além de garantir um bom nível de efetividade de negócios, tal qual seria com a operação na metrópole, garante menos stress e melhor qualidade de vida aos agentes envolvidos.

Guerreiro (2006) classifica Campinas entre as "cidades tecnológicas", pois a região "desenvolveu meios e potencializou recursos intelectuais e científicos para criar uma plataforma de operação a partir de aplicações tecnológicas das mais diversificadas" (GUERREIRO, 2006, p. 55). Como lembram DeMario, Ribeiro e Emiliano (2007):

reconhecida como pólo criador e difusor de tecnologia, a Região Metropolitana de Campinas conta com 21 instituições de ensino superior, sendo um importante fator de atração para empresas de alta tecnologia, seja pela elevada oferta de mão-deobra capacitada, seja pela contribuição destas para a criação e difusão de inovações de produtos e processos. (DEMARIO; RIBEIRO; EMILIANO, 2007, p. 95)

Entretanto, os autores também afirmam que Campinas detém "tanto a modernidade quanto a heterogeneidade social, pois convivem em um dinâmico mercado de trabalho com altas taxas de desemprego" (DEMARIO; RIBEIRO; EMILIANO, 2007, p. 95). 
Outras questões relativas ao pólo tecnológico de Campinas foram abordadas, através do instrumento de pesquisa, na segunda parte da pesquisa (descrita no tópico 3.3.2), através da entrevista que possibilitou os resultados elencados no tópico 5.1.

\subsubsection{São Carlos}

São Carlos é uma cidade do interior de São Paulo que, como Campinas, possui a vantagem de universidades conceituadas e de alta produção técnica em sua região. São os casos do Campus da Universidade de São Paulo - USP - e da Universidade Federal de São Carlos - UFSCar. Reúne um conjunto significativo de empresas de alta tecnologia, e é a sexta cidade brasileira em número de publicações científicas (HAYASHI, 2006).

Ainda em 1992, já eram verificadas por Torkomian e Medeiros (1994) várias dificuldades encontradas pelo órgão gestor do projeto do Pólo Tecnológico instituído na região, o Parqtec. Naquela época, São Carlos contava com cerca de 50 empresas de tecnologia de ponta, sendo que poucas atuavam no segmento de tecnologia de informação. Quase uma década antes, em 1984, a Prefeitura Municipal havia criado a Fundação Parque de Alta Tecnologia de São Carlos (Parqtec), em conjunto com o CNPq e com o CIESP (Centro de Indústrias do Estado de São Paulo). O projeto se desdobrou em uma boa estrutura de incubadoras de empresas (TORKOMIAN; MEDEIROS, 1994), mas poucas empresas de grande porte foram atraídas.

O estudo de Torkomian e Medeiros (1994) indicou a tendência de empreendedorismo entre os profissionais de São Carlos, oriundos em sua maior parte das universidades da região. Metade dos entrevistados de sua pesquisa eram engenheiros de formação que objetivavam possuir seu próprio negócio. Entretanto, diferente das condições encontradas nas regiões de Bangalore e do Vale de Santa Clara, havia uma distância considerável do pólo tecnológico de São Carlos para os mercados internacionais, com fortes impedimentos de ordem fiscal e política aos intentos das empresas da região. As empresas de São Carlos somente passaram a ter maior relevância frente ao mercado nacional na década de 1990, posteriormente à pesquisa de Torkomian e Medeiros (1994).

O fato da cidade de São Carlos ser reverenciada hoje como um Pólo de Alta Tecnologia está longe das determinações formais do termo. Poucas empresas encontram relevância nos mercados dos segmentos que atuam, tornando-se exemplos emblemáticos para as demais empresas da região. Assim como no caso de Campinas, a institucionalização do 
Pólo Tecnológico não derivou em desenvolvimento imediato desse, e muitas das iniciativas e projetos que poderiam possibilitar o surgimento de novas empresas na região ainda se encontram em segundo plano frente às políticas públicas do governo municipal, apesar dos intentos da administração do Parqtec, o que leva a crer que há sub-aproveitamento da capacidade regional para absorção de investimentos para as indústrias de Alta Tecnologia (conforme relatado pelo presidente do Parqtec em entrevista ao pesquisador).

Apesar da situação do desenvolvimento do Parque Tecnológico de São Carlos ser vista como longe da ideal por sua administração, que continua se esforçando para melhorar a situação do cluster frente ao mercado nacional de tecnologia, Dozena (2008) afirma que "o fato de São Carlos ser um dos Pólos Tecnológicos do estado de São Paulo (...) contribuiu e contribui para tornarem mais fortes as estratégias e ações públicas que visam os investimentos" (DOZENA, 2008, p. 92) no cluster da região. Segundo o autor, é perceptível que "a pujança econômica local é comandada pelo significativo Parque Industrial e amparada pelas dezenas de empresas incubadas na Fundação Parque de Alta Tecnologia de São Carlos Parqtec" (DOZENA, 2008, p. 92). Segundo o autor, São Carlos usufrui de uma ótima posição sócio-econômica dentro do Estado de São Paulo, melhor do que a da capital, o que contribui para a atração de investimentos.

Confrontando o histórico político com os índices de desenvolvimento social da região de São Carlos, Dozena (2008) conclui que as melhorias sociais surgem a partir da mudança de um "continuísmo político" que vigorou durante anos na cidade, com a eleição em 2000 do antigo reitor da UFSCar, candidato do Partido dos Trabalhadores à Prefeitura Municipal. Desde então, o partido continua na prefeitura, e outro ex-reitor da UFSCar ocupa atualmente o cargo de prefeito, o Prof. Dr. Oswaldo Barba.

As incubadoras administradas pelo Parqtec se tornaram referência na literatura nacional de inovação tecnológica. Segundo Medeiros (1992), "a lista de candidatos a uma vaga nas incubadoras de São Carlos (...) é considerável e a escolha das empresas que serão beneficiadas depende de alguns fatores" (MEDEIROS, 1992, p. 163), que vão da inexistência de outra empresa similar na região à exigência de não ser poluente. A principal característica das empresas de tecnologia da região se baseia em suas dimensões, sendo a grande maioria de pequeno e médio porte. Esse dado é validado por Diniz e Gonçalves (2005), que afirmam que:

O modelo de industrialização de São Carlos é diferente do de Campinas e São José dos Campos, cidades que contam com a presença de empresas multinacionais, pois a grande concentração de pesquisadores das instituições de ensino e pesquisa de 
São Carlos foi fundamental para a criação de pequenas empresas nacionais de alta tecnologia. (DINIZ; GONÇALVES, 2005, p. 161)

Ainda segundo Diniz e Gonçalves (2005), o movimento de empreendedorismo iniciado nas universidades da região aproximou a cidade do fenômeno de clusterização observado no Vale do Silício, salvas as devidas proporções.

Outras informações sobre a região de São Carlos foram obtidas na segunda etapa da pesquisa (ver tópico 3.3.2) pela prospecção de campo, através das entrevistas realizadas no cluster, e seus resultados frente ao instrumento utilizado são elencados no tópico 5.2 e seus subitens. 


\section{METODOLOGIA}

A composição desta metodologia de pesquisa se apoiou, em primeira instância, sobre os conceitos e premissas encontrados em Ritchie e Lewis (2003), Munhall e Chenail (2007), Patton (2002), Yin (2008), Gerring (2007) e Rocks, Carson e Gilmore (2007). A análise comparativa dos quatro modelos de desenvolvimentos regionais de pólos de TI abordados (Vale do Silício, Bangalore, Campinas e São Carlos) necessitou do cumprimento de várias etapas para que fosse atingido o objetivo geral, em busca de um referencial teórico que resolvesse o problema de pesquisa envolvendo o histórico do arranjo interno dos clusters como determinante, ou não, da excelência destes frente ao mercado. Cada uma das etapas possui características específicas, compondo um estudo de múltiplos casos que, de acordo com seu estágio, configurou-se como descritivo, exploratório ou explicativo (YIN, 2008).

A escolha das referências metodológicas iniciais se deu por conta da constatação das múltiplas características das etapas necessárias para solvência do problema de pesquisa. Segundo Rocks, Carson e Gilmore (2007), "a metodologia de estudo de caso é uma alternativa perspicaz para as abordagens mais convencionais de estudo de teoria de redes" (ROCKS; CARSON; GILMORE, 2007, p. 214), principalmente quando a rede em questão é composta por empresas e suas relações produtivas, tais quais se apresentam nos clusters. A pesquisa não se limitou ao estudo de apenas um cluster. Seu objetivo geral alinhou-se à formulação de um referencial teórico que elencasse as constatações oriundas das comparações entre os quatro casos abordados. Portanto, encaixou-se na perspectiva de comparação cruzada (cross-cases) das análises de múltiplos casos (YIN, 2008; ROCKS; CARSON; GILMORE, 2007). Segundo Yin, "estudos de caso podem cobrir múltiplos casos e então desenhar um arranjo único de conclusões de cruzamento dos casos" (YIN, 2008, p. 20).

O ponto de vista adotado para todos os estágios da pesquisa se baseou no pensamento sistêmico aplicado à administração, o que ressaltou o caráter qualitativo da mesma. Assim como observado nos arranjos produtivos estudados, a metodologia aqui apresentada estabeleceu-se sob a existência de relações de interdependência entre suas partes, que muitas vezes foram recursivas entre si. O objetivo geral delineado não seria atingido sem a compreensão adquirida pelo êxito no cumprimento dos objetivos específicos. O panorama delineado pela realização dos objetivos específicos indicou a fase final de análise, que teve como pano de fundo o pensamento sistêmico. 


\subsection{Tipo de Pesquisa}

A pesquisa se caracterizou como um estudo múltiplo de casos de caráter exploratório, de acordo com Yin (2008). Entretanto, suas etapas deram a impressão de tipos diferenciados dentro das possíveis classificações de estudo de caso. "Podem existir estudos de caso exploratórios, estudos de caso descritivos e estudos de caso explanatórios" (Yin, 2008, p. 8).

A primeira etapa da pesquisa, por exemplo, descrita no tópico 3.3.1 adiante, foi dedicada à revisão bibliográfica sobre o tema de pesquisa e os clusters abordados. Essa etapa pôde ser vista como descritiva, uma vez que por vezes tentou-se "descrever uma situação em profundidade, buscando ilustrar e dar realismo a ela, pela maior quantidade de dados e informações coletadas" (JOIA, 2006, p.128), mas não perdeu em momento algum o seu caráter exploratório, pois objetivou "gerar hipóteses que possam ser testadas por investigações futuras" (JOIA, 2006, p. 128).

As demais etapas passaram por momentos parecidos de ambigüidade em relação ao tipo de estudo de caso. Porém, sua abordagem central ainda se deu em função de gerar uma análise comparativa que fosse passível de engendrar novas interpretações sobre as relações estabelecidas entre as instituições ocupantes das regiões abordadas e o êxito econômico dos referidos clusters de TI. Isso caracterizou a pesquisa, de modo geral, como um estudo de múltiplos casos de ordem exploratória. Por ser um estudo de múltiplos casos, a pesquisa transitou entre análises quantitativas e qualitativas, mas seu aspecto geral foi essencialmente qualitativo, pela própria definição de estudo de caso. Como mostra Gerring (2007), "estudos de caso podem empregar uma grande variedade de técnicas - tanto qualitativas quanto quantitativas - para a coleta e análise de evidências" (GERRING, 2007, p. 33). Isso evidencia a complexidade da tipificação do tipo de pesquisa aqui apresentado. Para que houvesse legitimidade no enquadramento desta pesquisa entre os estudos de múltiplos casos de ordem exploratória, algumas premissas metodológicas foram observadas. Segundo Yin (2008) há cinco principais elementos de pesquisa para os estudos de caso, sendo estes o problema de pesquisa (questão de estudo), as proposições, as unidades de análise, a lógica ligando os dados e o problema de pesquisa e os critérios para interpretação dos resultados (YIN, 2008).

O problema de pesquisa foi delimitado no tópico 1.2. As proposições em estudos de caso de caráter exploratório, segundo Yin (2008), possuem "razão legítima por não possuir nenhuma proposição" (YIN, 2008, p. 28), pois “o tópico é o assunto de exploração" (YIN, 2008, p. 28). Se fosse necessário relatar o estabelecimento de uma preposição inicial para a consolidação deste estudo de múltiplos casos, provavelmente este se localizaria em torno da 
comprovação de relação entre tipo de arranjo interno dos clusters de TI e a realização de sua excelência frente aos mercados. Entretanto, o próprio arranjo interno, sob a perspectiva das relações estabelecidas entre os agentes dos clusters, foi o assunto principal da pesquisa e, baseando-se em Yin (2008), permitiu a inexistência de uma proposição explícita.

As unidades de análise são tratadas no tópico 3.2 adiante. A lógica ligando os dados e o problema de pesquisa se fundamentou nos métodos da terceira e, principalmente, da quarta etapa da pesquisa (descritas 3.3.3 e 3.3.4), nas quais se buscou a estruturação dos dados de forma compatível com o intento de compará-los de forma cruzada, extraindo as semelhanças e diferenças entre os clusters abordados de acordo com o que foi prospectado na literatura e no campo. Os critérios para interpretação dos dados seguiram uma lógica que respondeu ao problema de pesquisa, e se basearam nas premissas delimitadas pelo referencial teórico.

Uma vez satisfeitas as condições elencadas por Yin (2008) para a composição de estudos de caso, foi possível declarar com maior propriedade o tipo de pesquisa desenvolvida, enquadrando-a entre as análises comparativas de múltiplos de casos de caráter exploratório.

\subsection{Unidades de Análise}

Segundo Yin (2008), as unidades de análise estão "relacionadas ao problema fundamental de descrição sobre o que o case é” (YIN, 2008, p.29). Após a observação do referencial teórico sob a perspectiva da questão proposta pelo problema de pesquisa, entendese que o objeto de estudo direto deste trabalho é o arranjo interno de clusters de TI. Entretanto, qualificar o arranjo interno como unidade de análise primária exigiu a constatação de que outros elementos deveriam ser investigados para que essa análise fosse objetivamente atingida. Assim sendo, esta pesquisa não buscou exclusivamente focar uma unidade de análise específica que pudesse elucidar a questão proposta sobre a relação entre excelência de produção científica e de mercado e arranjos internos de clusters de TI.

A unidade de análise principal foi, sem dúvida, o arranjo interno do cluster. Mas este arranjo revelou-se um elemento complexo, composto por uma série de relações entre instituições e indivíduos com características distintas. Para tal análise, foi necessário ter em mente que havia outras duas unidades secundárias que deveriam ser mantidas em foco, sendo a primeira delas as relações entre indivíduos e instituições (ou grupos) dentro dos clusters, fossem elas estabelecidas com agentes internos ou externos. A segunda unidade secundária de análise foi a própria instituição (enquanto agente) ou mesmo o indivíduo. Distinguem-se as 
duas unidades secundárias de análise entre agente e relação. A composição de todos os agentes e relações em um cluster classificará seu arranjo interno.

Assim, teve-se por unidade de análise primária o arranjo interno dos clusters, ou seja, a forma como estes se configuram. As unidades secundárias de análise foram, respectivamente, as relações dadas entre os componentes do cluster e seus agentes.

\subsection{Etapas}

A pesquisa foi idealizada em etapas distintas que se complementam. A construção da metodologia de ação nas etapas seguintes somente foi possível após o cumprimento da primeira etapa, por esta oferecer subsídios para a estruturação do trabalho, oriundos de outras pesquisas aqui referenciadas. Uma vez que a pesquisa se tratou de uma análise de múltiplos casos, foi necessária a parametrização metodológica para o estudo dos casos abordados, para que não houvesse incongruência na posterior comparação dos resultados obtidos em cada um deles.

\subsubsection{Primeira Etapa: Revisão Bibliográfica}

A primeira etapa da pesquisa, de caráter bibliográfico, foi destinada à revisão da literatura sobre o tema e coleta de dados e informações disponíveis em pesquisas anteriores acerca dos quatro pólos tecnológicos em foco (Vale do Silício, Bangalore, Campinas e São Carlos). A revisão bibliográfica visou responder às questões dispostas no Apêndice A sobre as relações entre empresas e profissionais nos clusters abordados. Esta etapa compreendeu o cumprimento do primeiro objetivo específico, possibilitando a análise sobre o modelo de desenvolvimento dos casos internacionais. Por conta da raridade de bibliografia acerca dos pólos tecnológicos de TI nacionais, a primeira etapa da pesquisa não seria suficiente para a compleição do segundo objetivo específico, que tratou da análise das características dos modelos de desenvolvimento dos dois pólos tecnológicos nacionais escolhidos, Campinas e São Carlos, principalmente sobre as relações de seus agentes internos constituídas com outros agentes do cluster ou com agentes externos. Para tal, foi necessária a atividade de prospecção em campo, junto aos órgãos reguladores dos referidos clusters nacionais, para obtenção de informações que possam elucidar as questões levantadas no Apêndice A. 


\subsubsection{Segunda Etapa: Prospecção em Campo}

A segunda etapa se destinou à coleta de dados e informações que possam ser confrontados com os dados obtidos pela primeira fase da pesquisa, como complemento à bibliografia já estudada sobre os casos nacionais. Para isso, foi necessária a abordagem dos órgãos administrativos dos mesmos, em busca de informações acerca de suas relações entre os demais agentes do cluster, além daquelas relações estabelecidas com atores externos. Esse intento fez com que fosse criado um roteiro de entrevistas a ser aplicado em campo, disposto no Apêndice B, que fosse compatível com o roteiro da primeira etapa, registrado no Apêndice A. O roteiro não se constituiria em um cronograma de interpelações a ser seguido ordenadamente, mas somente um referencial que norteasse a ação do pesquisador no contato direto com os responsáveis pelos pólos tecnológicos nacionais. A prospecção de informações foi feita no modelo de entrevista, baseada no roteiro do Anexo B, mas sem limitar as possibilidades de abordagem de outros assuntos que viessem a colaborar com a formação de uma visão mais abrangente sobre os clusters. Conforme explicita Godoy (1995), os estudos de caso qualitativos exigem que o pesquisador tome contato direto com o objeto de pesquisa, percebendo outros elementos que não somente aqueles delimitados pelas respostas à entrevista (HAIR et al., 2005). Durante a prospecção em campo ocorreram quatro visitas do pesquisador aos clusters nacionais, que contribuíram para definir melhor a visão já obtida em contatos anteriores ao projeto. Entre 1999 e 2001, o pesquisador trabalhou alocado no Pólo II de Alta Tecnologia de Campinas, exercendo a função de gerenciamento das contas das empresas do cluster no Banco do Brasil. Apesar da vivência prévia, as visitas atuais foram de extrema importância para que o pesquisador avaliasse as mudanças ocorridas nos últimos nove anos e compusesse uma idéia atualizada sobre a dinâmica do cluster.

Todas as entrevistas foram gravadas em meio digital. Foram elas:

- Prof. Dr. Sylvio Goulart Rosa Jr., presidente do Parqtec São Carlos;

- Décio Sirbone Jr., diretor da incubadora de empresas nascentes da Ciatec, órgão gestor dos pólos tecnológicos de Campinas.

- Geziellen Silva, assessora de imprensa do Parqtec São Carlos;

- Emerson Leal, Secretário de Ciência e Tecnologia e Vice-Prefeito de São Carlos; 
- Diretor de uma empresa localizada no Pólo II de Alta Tecnologia de Campinas (Não identificado conforme termo de confidencialidade. Os dados da entrevista não foram inseridos na pesquisa a pedido da empresa).

\subsubsection{Dificuldades encontradas e soluções}

Inicialmente, vislumbrou-se a idéia de entrevistar diretamente uma grande quantidade das empresas dos clusters nacionais, a exemplo do modelo de pesquisa desenvolvido por Saxenian (1994, 2006). Entretanto, logo no início da segunda etapa, percebeu-se que as empresas abordadas (após definido o critério de amostragem) não poderiam, por considerar segredo estratégico de mercado, fornecer as informações necessárias para a resposta aos questionamentos elencados no roteiro presente no Apêndice $B$, ainda que sob termo de confidencialidade. Além da recusa em fornecer as informações pertinentes necessárias, haveria a possibilidade das respostas sofrerem distorções pelo receio de comprometer possíveis vantagens de mercado.

Uma das empresas inicialmente abordadas no cluster de Campinas - a qual foi visitada pelo pesquisador - solicitou que os dados informados na entrevista com um de seus diretores de pesquisa e desenvolvimento fossem desconsiderados, por receio de comprometimento da estratégia de mercado da empresa. A maioria das empresas inicialmente elencadas simplesmente se negaram a receber o pesquisador, informando por seus departamentos de relações públicas (e até mesmo por sua diretoria executiva) que não poderiam contribuir com a pesquisa por julgar as questões levantadas demasiadamente comprometedoras e sigilosas. Note-se que em todos os contatos foi afirmada a vontade de firmar termos de confidencialidade que garantissem o anonimato das empresas abordadas. A justificativa de algumas dessas empresas foi de que o termo de confidencialidade cobre apenas a publicação, não excluindo a possibilidade de obtenção das informações por concorrentes utilizando-se de "outros meios".

Outra barreira encontrada na delimitação da estratégia de prospecção em campo foi quanto à impossibilidade de estabelecer contato com o consórcio Encalso-Symetrix no cluster de São Carlos. Foram muitas as tentativas de identificar os responsáveis pelas operações do consórcio através do grupo de empreendimentos imobiliários Encalso-Damha, entretanto todas as tentativas não obtiveram êxito. Todavia, a busca pela resolução do problema de pesquisa não dependeria de dados extraídos da interpelação do referido consórcio, e todas as 
informações relevantes para avaliação das possibilidades de desdobramento do processo de desenvolvimento do cluster de São Carlos somente surgirão a partir da efetiva implantação da fábrica de semicondutores, marcada para 2011.

A opção escolhida para equacionar o problema de pesquisa foi a de abordar as instituições reguladoras dos parques tecnológicos de maior expressão nos clusters nacionais, o Parqtec em São Carlos e a Ciatec em Campinas, esta última incumbida da administração e desenvolvimento do Pólo II de Alta Tecnologia. As referidas unidades administrativas detêm informações significativas sobre as atividades desempenhadas nos clusters, incluindo as relações estabelecidas entre empresas. Como unidades gestoras de políticas para o desenvolvimento local, estão diretamente focadas em incrementar as conexões entre agentes no arranjo produtivo, no intuito de gerar - conforme os preceitos já abordados na literatura vista no Capítulo 2 - inovação que garanta incremento em competitividade.

Não bastasse o fato de serem promotoras de políticas relacionadas ao desenvolvimento dos arranjos produtivos, as instituições administradoras dos pólos tecnológicos se justificam como foco da prospecção de campo por aglutinarem as informações que seriam colhidas individualmente numa possível (mas dadas às restrições de acesso, impossível) abordagem mais ampla que levasse em conta a aplicação do roteiro de entrevista nas empresas que compõem o arranjo produtivo. Dessa forma, a utilização de uma abordagem que abrangesse a utilização de uma amostra do universo de pesquisa (entidades selecionadas entre as que habitam os clusters analisados) pôde ser substituída pela percepção dos gestores dos arranjos produtivos sobre o desdobramento das relações estabelecidas entre agentes internos e externos.

\subsubsection{Justificativa da escolha das fontes de pesquisa de campo}

Não há, para a composição do estudo de múltiplos casos, uma regra rígida quanto ao tamanho da amostra (YIN, 2008). A mesma pode ser substituída por um tipo de "metaamostragem", que seja a percepção generalizada - dada pela administração dos clusters abordados - a respeito dos temas elencados na pesquisa. Corroborando com essa possibilidade, principalmente no que se refere ao estudo qualitativo dos elementos que compõem a caracterização dos casos, há na literatura sobre a metodologia de composição de estudos de múltiplos casos a tendência de se obter informações referenciais que possibilitem a construção de uma estrutura teórica mais próxima do que é tido por comum na percepção dos 
grupos imediatamente ligados ao tópico estudado (MUNHALL; CHENAIL, 2007). Segundo Minayo (1999), a amostragem qualitativa não deve possuir uma amplitude pré-determinada, mas representar da melhor forma possível as características do grupo que representa (MINAYO, 1999). No contexto de detenção de informações mais gerais acerca das relações estabelecidas interna e externamente entre os agentes do cluster, nenhuma entidade possui maior relevância do que aquelas que se incumbem das políticas de incentivo de tais relações (entre outras atribuições). Portanto, tanto a Ciatec quanto a administração do Parqtec, no âmbito dos clusters nacionais analisados, são os componentes mais relevantes entre todas as possíveis configurações de amostra.

Este trabalho possui um formato recursivo, podendo ser visto como uma análise comparativa de múltiplos casos, cada qual formado pela percepção de pessoas relacionadas diretamente com a realidade dos clusters abordados. Enquadra-se na mesma classificação, por exemplo, do trabalho de Saxenian (1994), que pode ser visto como um estudo analítico comparativo de múltiplos casos (na verdade apenas dois, do Vale do Silício e da Rota 128) baseados em informações agrupadas por estudos de casos subjacentes (ou seja, das empresas que compõem as regiões estudadas).

De Saxenian (1994, 2006), surgiu a maior parte dos elementos que trazem à tona as respostas do instrumento de pesquisa do Apêndice A. Dessa forma, pode-se dizer que se tratou de uma composição baseada na percepção da pesquisadora sobre as questões relacionadas aos clusters do Vale de Santa Clara e de Bangalore. O instrumento de pesquisa do Apêndice B, uma vez aplicado aos responsáveis das entidades que administram os clusters nacionais abordados, deu origem a composições de respostas baseadas nas percepções dos administradores. Assim, os resultados apresentados a partir da escolha da abordagem específica dos órgãos de promoção da integração dos clusters abordados tendem a reproduzir as percepções de seus administradores, não necessariamente uma verdade irrefutável. Essa é uma das características mais marcantes da pesquisa qualitativa, a propriedade de se basear em percepções primárias e secundárias sobre os eventos estudados para compor processos cognitivos que articulem as informações adquiridas em campo (MINAYO, 1999).

Os dados obtidos através da aplicação do roteiro de estudo sobre as unidades administrativas dos dois clusters nacionais serão confrontados sob o método de cross-case (YIN, 2008), seguindo as etapas a seguir. 


\subsubsection{Terceira Etapa: Avaliação, Classificação e Tabulação de Dados}

A terceira etapa da pesquisa se destinou à tabulação, classificação e avaliação dos dados obtidos nas duas fases anteriores. Sua finalidade prática foi de parametrização dos elementos abordados, para que as comparações da etapa seguinte pudessem ser realizadas. Nessa etapa, foi desenvolvida uma planilha para organização das informações levantadas, conforme a metodologia de comparação cruzada de casos (cross-cases) proposta por Yin (2008).

A planilha tem dispostos sobre o eixo X (latitudinal) os casos abordados, além de uma coluna de resultados obtidos pela comparação entre os modelos internacionais e nacionais. $\mathrm{O}$ eixo Y (longitudinal) elenca as respostas obtidas para as questões de pesquisa elencadas nos instrumentos dos Apêndices A e B, conforme caracterizado na descrição das duas primeiras etapas.

\subsubsection{Quarta Etapa: Análise Comparativa}

Após a tabulação dos dados, foi necessário o estabelecimento de uma análise comparativa que fugisse à mera apresentação das diferenças e similitudes entre os modelos abordados, tentando também explicar o porquê de tais incongruências ou igualdades. Para que a análise comparativa traga resultados que possam, efetivamente, elucidar o problema de pesquisa, as explicações para as diferenças entre os modelos analisados encontrarão apoio na revisão bibliográfica sobre o tema.

Uma vez definida como um estudo de múltiplos casos de caráter exploratório, a pesquisa não pretendeu encerrar as questões sobre o tema, mas agregou informações relevantes sobre os clusters de tecnologia de informação abordados, processo que fez emergir novas interpretações a respeito da influência dos arranjos internos sobre o desempenho do cluster. A análise comparativa entre os casos levou em conta as condições sócio-históricas de formação de cada cluster, para que pudessem ser explicadas as diferenças de arranjo e de desempenho entre eles. 


\subsubsection{Quinta e última etapa: Redação do Relatório Final}

A quinta e última etapa da pesquisa foi destinada à redação do relatório final, em que serão repetidas as informações já dispostas neste projeto, acrescidas dos resultados da segunda, terceira, e quarta etapas.

No decorrer das etapas da pesquisa, houve movimentos de subtração ou adição de alguns dos itens apresentados na estrutura proposta no Apêndice $C$ da proposta avaliada na qualificação de mestrado, no intuito de melhor adequar a apresentação do relatório final aos resultados obtidos, assim como às eventuais mudanças de método ocasionadas pela interação com o campo na segunda etapa. Sobretudo, toda alteração do roteiro de composição foi fruto de sugestões da orientação em face às mudanças de contexto metodológico percebidas em contato com o campo de pesquisa, assim como de sugestões oferecidas pela banca de avaliação desta proposta.

\subsection{Protocolo}

O primeiro estágio da pesquisa se deu a partir de abril de 2008 , com o início da pesquisa bibliográfica acerca dos pólos internacionais de TI abordados. Durante a primeira fase da pesquisa foram avaliadas as referências que mais poderiam contribuir com a composição de um referencial teórico sobre as regiões que pudesse responder às questões levantadas no roteiro de pesquisa do Apêndice A. A política de prospecção bibliográfica foi baseada na relevância das obras analisadas frente à produção acadêmica da área. Em muitos casos, os textos escolhidos eram os únicos disponíveis sobre o assunto, mas todos dotados de uma metodologia de composição válida, baseada no método científico, garantindo a qualidade técnica do referencial teórico a ser composto por esta pesquisa.

A partir do estabelecimento dos parâmetros para escolha das referências bibliográficas básicas, foi possível realizar o protocolo de pesquisa, definindo os passos de composição das etapas de pesquisa, assim como seu modo de operação. Segundo Yin (2008), "possuir um protocolo de estudo de caso é desejável sob todas as circunstâncias, mas é essencial nos estudos de múltiplos casos" (YIN, 2008, p. 79). Dessa forma, apesar da metodologia ora exposta contemplar parte da descrição do protocolo de pesquisa, a formalização do mesmo se dá pelo instrumento presente no Apêndice C. 
A composição do protocolo de pesquisa (Apêndice C) seguiu os critérios delimitados por Yin (2008), levando-se em conta as necessidades observadas para resolução do problema de pesquisa, primando pela realização do objetivo geral e dos objetivos específicos delimitados. A definição de protocolo de pesquisa de Remenyi e Money (2004) o considera:

\footnotetext{
Um documento que descreve os aspectos da pesquisa proposta e que demonstra que o pesquisador pensou sobre todos os assuntos chave pertinentes ao tema da pesquisa assim como sobre os processos do projeto de pesquisa e a forma como os resultados da pesquisa serão apresentados. (REMENYI; MONEY, 2004,p. 82)
}

Procurou-se levar em conta, antes mesmo do atendimento às necessidades oriundas da prospecção de respostas às questões suscitadas pelo tema, equacionar a oposição entre os preceitos éticos da confidencialidade e transparência da obtenção dos dados apresentados. Para tal, objetivou-se - após mudança de critério de determinação do escopo da amostra englobar informações dispostas apenas pelas fontes identificadas.

O protocolo de pesquisa não serviu, em nenhum momento, como um cronograma de atividades, mas como um guia que pautou as atividades para que não se perdessem as finalidades básicas do trabalho e que seus resultados estivessem à luz de procedimentos coerentes com o que se previa atingir a partir da proposta inicial de trabalho. 
Quadro 2

\begin{tabular}{|c|c|c|c|c|c|c|}
\hline Etapa & $\begin{array}{l}2^{\circ} \text { e } 3^{\circ} \\
\text { Trim } \\
2008\end{array}$ & $\begin{array}{c}4^{\circ}-\text { Trim } \\
2008\end{array}$ & $\begin{array}{c}1^{\circ} \text { Trim } \\
2009\end{array}$ & $\begin{array}{c}2^{\circ} \text { Trim } \\
2009\end{array}$ & $\begin{array}{c}3^{\circ} \text { Trim } \\
2009\end{array}$ & $\begin{array}{c}4^{\circ} \text { Trim } \\
2009\end{array}$ \\
\hline $\begin{array}{l}\text { 1. Revisão bibliográfica e coleta de dados, } \\
\text { buscando por informações disponíveis em } \\
\text { pesquisas anteriores acerca do tema. }\end{array}$ & $\mathbf{X}$ & $\mathbf{X}$ & $\mathbf{X}$ & $\mathbf{X}$ & $\mathbf{X}$ & \\
\hline $\begin{array}{c}\text { 2. Entrevista presencial nas empresas de } \\
\text { tecnologia de pequeno e médio porte e coleta } \\
\text { de dados regionais nos organismos } \\
\text { governamentais e de regulação das atividades } \\
\text { empresariais nas regiões de Campinas e São } \\
\text { Carlos. }\end{array}$ & & & $\mathbf{X}$ & $\mathbf{X}$ & $\mathbf{X}$ & $\mathbf{X}$ \\
\hline $\begin{array}{l}\text { 3. Avaliação, classificação e tabulação dos } \\
\text { dados coletados pela pesquisa bibliográfica } \\
\text { (monografias e indicadores regionais). }\end{array}$ & & & & $\mathbf{X}$ & $\mathbf{X}$ & $\mathbf{X}$ \\
\hline $\begin{array}{l}\text { 4. Elaboração de confrontos entre os dados } \\
\text { adquiridos e informações analisadas, } \\
\text { delineamento das diferenças e similitudes dos } \\
\text { modelos analisados e proposição de novos } \\
\text { modelos, compatíveis com o regional dos casos } \\
\text { nacionais. }\end{array}$ & & & & & $\mathbf{X}$ & $\mathbf{X}$ \\
\hline 5. Redação do relatório final. & & & & & $\mathbf{X}$ & $\mathbf{X}$ \\
\hline
\end{tabular}

Cronograma de Atividades

Fonte: Autor 


\section{RESULTADOS DA PESQUISA DOS CLUSTERS INTERNACIONAIS}

Visando seguir os procedimentos descritos no Capítulo 3, a primeira fase da pesquisa buscou identificar, através da ampla literatura disponível, as respostas para o roteiro de pesquisa do apêndice A. A partir da pesquisa bibliográfica, concluiu-se que a grande maioria dos pesquisadores que argumentaram sobre os clusters do Vale do Silício e de Bangalore se alinha em sua percepção acerca dos modelos de desenvolvimento adotados em cada região.

A pesquisa bibliográfica pôde também desmistificar muitas das impressões do pesquisador a cerca do fenômeno de Brain Circulation, mostrando que o movimento de modernização e desenvolvimento ocorrido em Bangalore não se desdobrou em resultados sociais parecidos com os que foram observados no Vale de Santa Clara nas primeiras décadas da chamada Revolução Informacional. De fato, apesar de estar atrelado a um modelo de empreendedorismo oriundo do cluster californiano, o desenvolvimento de Bangalore é muito específico, por tratar-se de uma região que ainda possui os mesmos problemas que o resto do país no que tange ao desenvolvimento social e disponibilidade de recursos energéticos e hídricos.

A seguir, discorre-se sobre os resultados, à luz do instrumento de pesquisa, da prospecção bibliográfica em busca de respostas que orientem à solução do problema de pesquisa em questão, sobre como os arranjos produtivos internos dos clusters de TI e as relações estabelecidas entre seus agentes durante seu desenvolvimento contribuem, ou não, para sua manutenção sistêmica após a consolidação de sua estrutura, e como esses arranjos e relações se dão. Todas as respostas foram concebidas a partir da percepção do pesquisador sobre os elementos de maior relevância expostos na bibliografia adotada, o que significa dizer que os resultados são frutos da impressão pessoal, pautada pela metodologia escolhida, a respeito dos fenômenos estudados em relação aos arranjos produtivos internacionais abordados e suas particularidades.

\subsection{Respostas ao instrumento de pesquisa sobre o Vale do Silício}

A prospecção de dados sobre o Vale do Silício contou com vasta literatura, mas teve como destaque os trabalhos de Saxenian $(1994,2006)$, que desenhou ao longo de seus anos de pesquisa um consistente referencial teórico, que influenciou na escolha do tema desse 
trabalho. Todas as respostas às perguntas levantadas nos instrumentos de pesquisa são dedutíveis a partir do histórico delimitado no tópico 2.5.1.

\subsubsection{Como se deu o processo histórico de desenvolvimento do Vale do Silício?}

A partir do que é possível verificar através de Saxenian (1994), Bylinsky (1976), Lécuyer (2006) e Stiglitz (2003), o processo histórico de desenvolvimento do Vale do Silício se deu sob o ímpeto de empreendedorismo local, característica que já era percebida no final dos anos 1930, quando emergiu na região a atualmente gigante empresa de equipamentos Hewlett-Packard. A presença de universidades de ponta permitiu que os recursos humanos fossem suficientes aos primeiros empreendimentos. $\mathrm{Na}$ maioria das vezes, esses empreendimentos derivavam de pesquisas e descobertas de estudantes das instituições técnicas locais ou inventores de fundo de quintal, que passaram a buscar recursos para abrir seus próprios negócios em bancos e linhas de financiamento do governo. Alguns dos primeiros empreendedores contaram com recursos oriundos de investidores que, em momentos anteriores, haviam alavancado ganhos através do mercado financeiro e da indústria de entretenimento (BYLINSKY, 1976), mas a maior parte dos investimentos vinha de fontes externas ao Vale de Santa Clara. A partir dos pequenos empreendimentos estabelecidos e de seu precoce sucesso, a região se beneficiou dos contratos estabelecidos com o governo e outras empresas do leste do país, o que chamou a atenção de outras companhias de eletrônica atuantes na região leste. Grandes companhias passaram a abrir suas unidades na região, ao passo que as bem sucedidas empresas de tecnologia nascidas na região, outrora pequenas manufaturas situadas às garagens de seus proprietários, atingiram o tamanho de suas então rivais do leste.

Pode-se dizer que o elemento que esteve presente em todos os estágios da projeção histórica do desenvolvimento do cluster foi a cultura voltada para o empreendedorismo, que garantiu o estabelecimento de novos negócios de forma contínua e permitiu a competitividade frente às demais empresas de tecnologia do leste.

Além do ímpeto empreendedor, outro fator de destaque foi a capacidade de estabelecer conexões entre as diversas organizações do mesmo setor alocadas na região. Isso fez com que emergisse um sentimento de pertencimento a um tipo de "clã" de empresas, que permitiu a consolidação de competências compartilhadas, articuladas sistemicamente. 


\subsubsection{Quais as características econômicas que propiciaram o surgimento do cluster no Vale de Santa Clara?}

A região de Santa Clara se baseava essencialmente no comércio e produção industrial de base diversificada, ao menos até o final da década de 1950 (SAXENIAN, 1994). A partir do sucesso dos primeiros empreendimentos de tecnologia eletrônica e do renome atingido pelos profissionais dos centros de tecnologia e universidades instalados na região, os olhos dos investidores de todo o país, inclusive do governo, se voltaram para o Vale. Pode-se dizer que os recursos econômicos que propiciaram a emergência do cluster estão ligados ao governo federal - que levou a frente o delineamento de uma política favorável ao desenvolvimento tecnológico da Califórnia - e aos investidores financeiros de outras regiões que cunharam um tipo de negócio espacialmente conectado ao modelo de desenvolvimento do informacionalismo, as empresas de capital de risco.

O governo teve particular interesse na região a partir da década de quarenta, quando os esforços de guerra solicitavam o desenvolvimento de novas tecnologias capazes de lidar com o aparato de comunicação e processamento de informações dos inimigos. A modernização do poderio bélico americano fez com que diversos contratos fossem estabelecidos com empresas da região, e possibilitou que outras tantas surgissem a reboque das oportunidades atreladas às necessidades governamentais. A presença de mentes brilhantes - muitas delas, a essa altura, vindas de fora dos Estados Unidos - garantia confiabilidade aos investimentos de risco em desenvolvimento tecnológico, o que possibilitou a abundância de recursos para criação do Vale do Silício.

\subsubsection{Como se deram as relações entre governos, instituições de ensino, institutos de pesquisa e empreendedores na concepção e implantação do cluster?}

Não houve, pelo menos em um primeiro momento, a intenção deliberada de estabelecer na região um arranjo produtivo de tecnologia de informação. Pelo contrário, os primeiros empreendimentos foram orientados pela vontade de materializar novas descobertas e comercializa-las. O governo americano investiu pesadamente no desenvolvimento de tecnologias através de aporte direto a institutos privados e públicos, além de financiamentos e subsídios a empresas de tecnologia do setor privado, a partir do final da primeira metade do século XX. A "vocação" do Vale do Silício para abrigar um cluster de tecnologia da 
informação já era percebida nessa época, com a presença de alguns empreendimentos de sucesso e a instalação das primeiras subsidiárias de empresas grandes do leste do país. O empenho de guerra favoreceu ao desembaraço imigratório àqueles profissionais e pesquisadores que se mudaram para a região para colaborar com o processo de desenvolvimento. Mas foi mesmo a partir do meio da década de 1970 que houve a expansão sem precedentes daquilo que viria a se tornar o cluster emblemático de TI em nível mundial (SAXENIAN, 1994). O governo incentivou o processo de desenvolvimento com incentivos fiscais (em um primeiro momento) e o estabelecimento de contratos para a área de defesa com as empresas que se implantavam (ALLAN, 2001). Apesar de não haver uma articulação explícita entre empresas, empreendedores e governo, pouco a pouco foi emergindo na região a sensação de pertencimento a um novo tipo de indústria, sedimentado sobre um novo tipo de arranjo produtivo, o que contribuiu para o alinhamento das decisões que concretizaram a instalação do Parque Tecnológico.

As instituições de pesquisa e instituições de ensino desenvolvem um papel fundamental na existência do cluster, ao passo que favorecem a emergência de novas tecnologias e do processo de inovação. Além disso, a maioria dos empreendedores vinha das universidades e institutos de pesquisa. Essas instituições exercem parcerias com as empresas de tecnologia que visam melhorias de estruturas e fomento de pesquisas em troca de colaboração em tecnologias que possam derivar em produtos inovadores. Algumas empresas chegam a financiar os laboratórios das universidades, entre outras ações, para que tenham participação nas patentes industriais de tecnologias que venham a ser descobertas através do uso das instalações, em face de acordos específicos para cada pesquisa desenvolvida. Iniciativas desse tipo são firmadas a todo instante em todas as instituições de ensino do cluster, comuns até mesmo nos centros técnicos de menor expressão.

\subsubsection{Qual a relação entre o estabelecimento do Vale do Silício e o volume de mão de obra especializada disponível na região?}

Hoje em dia é possível perceber o grande volume de mão de obra qualificada disponível na região, sendo que o setor que abriga a maior parte da população economicamente ativa de alto nível instrucional é o de TI (SAXENIAN, 2006). Entretanto, na década de 1950 era escassa a mão de obra técnica ao nível do que era exigido pelo tipo de pesquisas e produtos desenvolvidos na região. Para que o cluster pudesse realizar o salto 
qualitativo verificado a partir dos anos 1970 em relação à sua economia e relevância de mercado foi necessária a imigração de mão de obra de diversos países. Na mesma época, como visto em Saxenian (2006), salas inteiras das escolas de tecnologia da Índia acabavam por se deslocar para os Estados Unidos para suprir as necessidades de expansão econômica do cluster do Vale do Silício. A partir do desenvolvimento de novas vagas para estudantes em universidades locais que pudessem colaborar com o quadro de funcionários das empresas da região sob alto nível técnico, a necessidade de mão de obra externa foi diminuindo, mas ainda há uma quantidade relevante de imigrantes instalados no Vale do Silício. Muitos desses imigrantes abriram suas próprias empresas, e hoje estabelecem relações comerciais com outros mercados nos Estados Unidos e em seus países natais (SAXENIAN, 2006).

\subsubsection{Quais os tipos de relações estabelecidas entre as empresas do Vale do Silício e como elas se dão? Existe predominância de algum dos tipos sobre os outros?}

As relações produtivas entre as empresas do Vale do Silício possuem diversas configurações (BERNAHAN; GAMBARDELLA, 2004), estabelecendo no interior do cluster múltiplas redes de variados níveis. A partir de um produto final, é possível identificar diversas organizações articuladas em prol de sua constituição, muitas vezes instaladas em uma mesma

planta produtiva (regime de consórcio ou condomínio de empresas). É possível encontrar empresas que dediquem todo o seu esforço produtivo a apenas um sub-produto ou um cliente (SAXENIAN, 1994), mas a grande maioria busca a diversificação de suas atividades e de suas relações com o mercado. Dessa forma, é possível identificar uma articulação complexa entre as empresas que não se dá apenas pelo compartilhamento do espaço físico ou dos recursos regionais, mas se desdobra nas relações das diversas cadeias produtivas que podem operar.

Quando se percebe que a maioria dos empreendimentos não se prende a um único tipo de operação, buscando clientes e parceiros em vários níveis, dentro e fora do cluster, percebese aquilo que poderia ser classificado como um modelo multinucleado, onde não há um agente central que prevaleça nas atividades desempenhadas no arranjo produtivo, ou sequer disponha de um nível de relevância que possa comprometer a existência das demais empresas. 


\subsubsection{Há relação de hierarquia, evidenciando um grau de importância de uma empresa} frente às outras, nos processos produtivos ou nas diversas relações estabelecidas entre as empresas do Vale do Silício?

Inicialmente, essa relação de hierarquia não é verificada como uma tendência. Há a possibilidade de se verificar a existência de algumas start ups voltadas para o suprimento de necessidades específicas de algum outro arranjo produtivo interno (BERNAHAN; GAMBARDELLA, 2004), entretanto isso não se repete com freqüência. A cultura organizacional da região age como um estimulante para a geração de diversas relações entre os agentes locais, diversificando as relações comerciais e diminuindo a relação hierárquica entre as organizações. Existem casos de empresas que iniciam suas atividades como departamentos terceirizados de empresas maiores e, ao se desenvolverem, passam a operar no mercado fornecendo para outros agentes, muitas vezes estabelecendo redes de cooperação com concorrentes diretos daquelas empresas que lhe possibilitou o surgimento (SAXENIAN, 1994).

Quanto à relevância decisória frente aos processos políticos e econômicos da região, muitas grandes empresas possuem importância, mas esta é compartilhada. Não há casos preponderantes de grande monopólio - talvez o que mais se aproxime de algo do tipo é o da Microsoft - e é muito improvável que o colapso de um dos agentes se desdobre em uma crise que ameace a manutenção da existência do cluster (STIGLITZ, 2003). Dessa forma, é verificado baixíssimo nível de dependência interna, ainda que não seja possível através de instrumentos de mensuração definir isso sob os métodos elencados para constituição desta pesquisa.

\subsubsection{Qual a participação inicial do Vale do Silício no volume de negócios do setor de TI?}

O Vale do Silício possui expressão tão preponderante no setor de Tecnologia da Informação que é possível afirmar que a absoluta maioria dos produtos eletrônicos formados por hardware e software comercializados em nível global tenha em sua constituição mais de um elemento patenteado por empresa ou centro de pesquisa instalado no cluster. Significa dizer que todo computador, celular ou outro aparato eletrônico de comunicação produzido nas últimas duas décadas detêm alguma tecnologia originada no Vale do Silício (SAXENIAN, 1994; LÉCUYER, 2006). Entretanto, as coisas eram bem diferentes até o final dos anos 1960. 
Até o final dos anos 1950, a produção do Vale do Silício era muito menor do que a verificada na Rota 128, mas já conseguia competir com semelhança de recursos com algumas das empresas européias do segmento de TI. A partir dos anos 1960, o número de companhias de tecnologia locais cresceu mais rápido, quando finalmente na década de 1970 disparou. Pode-se dizer que o desenvolvimento do cluster foi mais lento do que a maioria dos empreendimentos com as mesmas características, por ter acontecido de forma espontânea, a partir dos empreendedores ligados às universidades e institutos de pesquisa da região.

\subsubsection{Como se estabeleceu a rede de relações entre os agentes do Vale do Silício (empresas e pessoas) após o início de suas atividades?}

As relações entre os agentes de do Vale do Silício sempre foram baseadas em sinergia, e em um segundo momento, em "competição sinérgica" (apesar da competição declarada de produtos finais, etapas da produção são desempenhadas pelo compartilhamento de recursos, direta ou indiretamente). Dessa forma, as pessoas envolvidas nos processos produtivos ou investigativos ligados à tecnologia de informação sempre mantiveram algum nível de contato, seja por trabalharem sobre o mesmo tema (nas universidades ou na indústria) ou por fazerem parte dos mesmos grupos sociais.

A questão dos grupos sociais é a mais relevante no caso do relacionamento interpessoal do Vale do Silício. Diversos autores apontam para a existência de redes informais de relacionamento como indutora de inovação. Segundo Saxenian (1994), muitas das conversas informais estabelecidas em rodas de amigos e colegas de trabalho fora do expediente garantiam o fluxo informacional entre empresas, além de manter a cultura organizacional voltada para a cooperação entre organizações. De fato, apesar dos diversos dispositivos de segurança criados para proteger a produção intelectual na região, era através das pessoas e suas relações informais que o conhecimento tácito era transferido com adendos competitivos de imensa importância. A troca de recursos humanos entre empresas também é uma realidade até os dias de hoje. Quando um funcionário sai de uma empresa para ocupar uma vaga em um concorrente ou outra organização estabelecida no arranjo produtivo, leva consigo conhecimentos atrelados à lógica de desenvolvimento tecnológico de todas as empresas em que trabalhou. As relações informais propiciaram o fluxo de informações relativas ao preenchimento de vagas e perfis de profissionais mais indicados para cada projeto, exercendo-se o networking desde a universidade até a empresa. 


\subsubsection{Como se dá o fluxo de transferência de conhecimento entre as empresas do Vale do} Silício, entre agentes de outros Sistemas Regionais de Inovação e mesmo entre agentes de outros Sistemas Nacionais de Inovação?

No Vale do Silício são comuns os acordos de cooperação em pesquisa e desenvolvimento entre empresas, centros de pesquisa e universidades (SAXENIAN, 1994; 2006). As empresas que oferecem produtos finais se articulam com empresas produtoras de componentes específicos, sejam da região ou de outros lugares no mundo. A partir dos anos 1990, parte das cadeias produtivas mais importantes em TI, coordenadas por corporações do Vale do Silício, passou a ter componentes de outros clusters envolvidos na rede de desenvolvimento de produtos. Foi quando surgiram os clusters de Bangalore e Xangai.

As transferências de informações formais relativas à tecnologia desenvolvida em parceria são pautadas por acordos de confidencialidade entre os membros de uma cadeia de pesquisa e desenvolvimento, que permitam que o conhecimento adquirido mantenha-se como vantagem competitiva apenas para as organizações envolvidas no consórcio. Esse padrão é adotado também nos acordos de parceria do Vale do Silício, sejam internos ou internacionais (SAXENIAN, 2006). Entretanto, o tipo de conhecimento mais importante em fluxo contínuo no Vale do Silício é o conhecimento tácito. As freqüentes trocas de emprego dos profissionais do cluster californiano fazem com que informações importantes do contexto organizacional das empresas, e até mesmo a respeito do desenvolvimento de novas tecnologias, migrem de uma empresa para outra através do fluxo de recursos humanos.

Quanto ao estabelecimento de parcerias internacionais, a presença dos imigrantes no Vale do Silício, outrora como empregados das empresas de tecnologia e agora como empreendedores, faz com que sejam possíveis conexões com áreas remotas, mas ricas em mentes brilhantes e mão de obra especializada, como Xangai, Bangalore, Tel Aviv e outros clusters de excelência (SAXENIAN, 2006). 


\subsubsection{Entre os sub-setores da Tecnologia da Informação (software, serviços,} semicondutores, etc.), quais aqueles que obtiveram destaque entre os empreendimentos estabelecidos no Vale do Silício, tanto por seu volume de negócios como por sua excelência em inovações para o mercado?

O Vale do Silício tem sua produção diversificada entre os vários sub-segmentos da Tecnologia de Informação. Inicialmente, as empresas de maior relevância estavam relacionadas ao desenvolvimento e produção de semicondutores, processadores e memórias, componentes do hardware de equipamentos de TI. Entretanto, com o passar do tempo, a região também se tornou expressiva - e por algum tempo hegemônica - na produção de softwares e serviços relacionados a TI. Pode-se dizer que hoje, o Vale do Silício tem sua relevância apoiada sobre os centros de pesquisa e empresas que voltam suas atividades para prospecção de novas tecnologias, nas diversas áreas ligadas à indústria de TI. Entretanto, a montagem de produtos finais e a fabricação de muitos dos componentes de hardware já não estão mais entre as atividades de maior relevância do cluster, tendo migrado para plantas produtivas asiáticas devido ao reduzido custo operacional (SAXENIAN, 2006; BERNAHAN; GAMBARDELLA, 2004).

\subsubsection{Qual a importância do poder público e da legislação vigente para a manutenção do Vale do Silício?}

O governo ainda mantém uma boa parte de seus contratos de defesa no Vale do Silício, mas o cluster sempre teve importância secundária para este cliente quando comparado com a Rota 128 (SAXENIAN, 1994). De fato, o diferencial do cluster californiano frente às zonas de desenvolvimento de novas tecnologias do leste do país é a diversificação de seus clientes finais. Entretanto, a importância do poder público ainda é grande por conta das políticas públicas que viabilizam o surgimento de novos empreendimentos na região (BYLINSKY, 1976; BERNAHAN; GAMBARDELLA, 2004). 


\subsubsection{Qual a posição sócio-econômica da região onde o Vale do Silício está estabelecido} frente ao padrão americano e aos padrões das regiões dos demais pólos tecnológicos do mesmo setor (limitando-se aos estudados)?

A Califórnia, a partir do começo do século XX, manteve um ótimo padrão econômico até os dias de hoje. San Diego, por exemplo, é a cidade com o maior salário médio do país (THOMAS, 2007), e o Vale de Santa Clara, ao norte dessa região, está entre as dez regiões mais ricas dos Estados Unidos. De certa forma, o Vale do Silício está no epicentro de uma das regiões de maior PIB do mundo, a Costa Oeste dos Estados Unidos.

Frente aos demais clusters de tecnologia da informação em disputa pelo mercado mundial, o Vale do Silício ainda detém hegemonia por abrigar as bases operacionais da parte mais expressiva das companhias do setor.

\subsubsection{Há relação entre os fatores de desenvolvimento social da região com o pólo tecnológico?}

No Vale do Silício, quem não trabalha diretamente com TI, está conectado de alguma forma com a receita advinda de sua atividade. A expressão do setor para a economia da região do Vale de Santa Clara é tão grande que é impossível viver no condado sem ter contato com algum profissional ligado ao cluster tecnológico (SAXENIAN, 1994). O sucesso econômico do cluster trouxe melhorias para a maior parte da população, e é possível dizer que possibilitou o desenvolvimento de uma infra-estrutura civil que alavancou os níveis de desenvolvimento humano não só da região, mas com impactos positivos em toda a Califórnia.

A intensificação das relações entre profissionais gerou um sentimento de pertencimento a uma comunidade regional que impulsionou as iniciativas de contribuição social. Grande parte dos funcionários do Vale do Silício doa parte de seu tempo para atividades sociais, e as empresas desenvolvem projetos sociais voltados ao acesso à educação para a população de áreas socialmente menos desenvolvidas desde a década de 1980. Por tratar-se de uma das regiões mais abastadas dos Estados Unidos, é também um marco econômico para o capitalismo informacional, e tamanha relevância contribuiu para que as receitas aferidas pelo sucesso do cluster fossem empregadas, em justa medida, no desenvolvimento social da região. 


\subsubsection{Como o pólo tecnológico se integra com o desenvolvimento de pesquisa científica da região que ocupa? Qual sua participação no estabelecimento de implementos educacionais da região?}

As empresas do Vale do Silício exercem grande influência sobre a produção dos centros de pesquisa e universidades do Condado de Santa Clara. Muitas dessas instituições são financiadas por projetos estabelecidos em parceria com empresas de tecnologia, o que faz com que essas determinem, ainda que indiretamente, aquilo que deverá constar no rol de projetos internos, de acordo com as oportunidades observadas no mercado (BERNAHAN; GAMBARDELLA, 2004).

Muitos dos projetos de expansão do sistema educacional do Vale de Santa Clara são inteiramente patrocinados pelas empresas do cluster, o que garante a emergência de novos talentos para a manutenção da competitividade do arranjo produtivo no futuro.

\subsection{Respostas ao instrumento de pesquisa sobre Bangalore}

A bibliografia acerca do caso de Bangalore pode ser considerada mais rica do que a do Vale do Silício, não por conta de seu volume - que atualmente chega próximo ao que foi produzido sobre o cluster californiano - mas por envolver teóricos voltados para a análise de países em condições diferenciadas de desenvolvimento. A maioria dos autores que se debruçam a estudar o cluster de Bangalore é indiana, mas também há chineses, americanos e outros que contribuem com prismas oriundos de culturas muito distintas para a formação de um referencial teórico de múltiplas perspectivas. Diferentemente do que é verificado na literatura acerca do Vale de Santa Clara, a preocupação da maioria dos autores que relata a experiência do pólo tecnológico indiano é de ancorar os resultados econômicos com a questão do desenvolvimento social, tendo em vista que a Índia ainda é um dos países que mais sofre com a exclusão social e o baixo nível de acesso a condições dignas de vida. 
O caso de Bangalore se aproxima mais do caso brasileiro, não pela historicidade, mas por se tratar de um país que ainda abriga diversos problemas sociais relacionados à falta de equidade econômica e social, derivada do que os teóricos das ciências sociais chamam de capitalismo tardio (CARDOSO DE MELLO, 1982). Observando-se atentamente as relações que se dão no interior do cluster, é possível perceber através do que foi explicitado na literatura consultada que o cluster detém características peculiares da cultura organizacional do Vale do Silício, adquiridas pelo fenômeno de Brain Circulation (SAXENIAN, 2006), mas ainda mantém elementos culturais ligados aos dogmas seculares que insistem em preservar apesar dos intentos em modificar isso - as relações sociais dadas pelo tradicionalismo do sistema social indiano.

Primeiramente, é necessário perceber que Bangalore, ainda que mantenha contato com elementos da cultura indiana, não pode ser entendido como um caso representativo do que ocorre em toda a Índia. Como muito bem observado por todos os autores abordados, o cluster está mais conectado com a realidade do mercado global de tecnologia de informação do que com as questões pertinentes ao desenvolvimento social da Índia como um todo, apesar das tentativas do Estado indiano em disseminar o padrão de desenvolvimento identificado em Bangalore para outras regiões do país.

\subsubsection{Como se deu o processo histórico de desenvolvimento do cluster de Bangalore?}

Como salientado por Saxenian (2006), muito mais importante do que a predisposição do governo local para implantação do parque tecnológico de Bangalore foi a experiência adquirida por boa parte de seus empreendedores através dos processos de Brain Drain e Brain Circulation, nos quais as mentes mais brilhantes do país imigravam para os Estados Unidos em busca de melhores condições de vida em cargos de pesquisa e desenvolvimento nas empresas do Vale do Silício e da Rota 128, pólos hegemônicos em TI em nível global até meados dos anos 1990 (e ainda muito importantes nos dias de hoje), e depois retornavam a regiões específicas de seus países para contribuir com o desenvolvimento local.

O parque tecnológico de Bangalore atingiu reconhecimento internacional a partir da primeira metade da década de 1990, quando passou à situação de concorrente direto das maiores companhias de desenvolvimento de software americanas. Além das atividades 
relacionadas à pesquisa e ao desenvolvimento de novas tecnologias, Bangalore encontrou reconhecimento em serviços relacionados ao atendimento de suporte técnico a consumidores de produtos de TI desenvolvidos em diversas regiões do mundo, consolidando a imagem de uma região conectada com o ambiente de mercado global (ASHWANI; VIJAYABASKAT, 2005).

A partir do desenvolvimento do conceito de STP (Software Technology Park) foi possível, entre o final da década de 1980 e início da década de 1990, oferecer condições econômicas favoráveis para o desenvolvimento de um cluster de excelência em TI, que fosse convidativo ao retorno dos muitos imigrantes especializados em desenvolvimento tecnológico vivendo nos Estados Unidos e outras regiões de excelência tecnológica e econômica. O que favoreceu esse retorno foi o fato de que esses profissionais nunca perderam de vez suas relações com os países natais (SAXENIAN, 2006).

Aproveitando-se do processo de consolidação do cluster iniciado com o retorno dos novos argonautas (SAXENIAN, 2006), diversas empresas de grande porte resolveram abrir unidades de desenvolvimento na região, iniciando um acentuado fluxo de instalação de multinacionais, que desde a saída da IBM na década de 1970 parecia ser impossível de acontecer. A receita era simples: mentes brilhantes a custos consideravelmente mais baixos do que em qualquer outra parte do mundo.

\subsubsection{Quais as características econômicas que propiciaram o surgimento do cluster na região de Bangalore?}

A Bangalore da década de 1940 contava com uma estrutura típica de uma região voltada para o lazer, tendo sido fundada inicialmente com a intenção de servir como estação de veraneio aos políticos e militares ingleses e indianos durante o período sob o domínio britânico. Estar no campo de visão da elite dominante do país contribuiu com o estabelecimento de uma série de políticas públicas voltadas para o desenvolvimento econômico da região. Em termos relativos à Índia, é possível dizer que alguns dos fatores de desenvolvimento social, tais como instituições de ensino, são mais evidentes em Bangalore do que na maioria das regiões do país, fato que coincide com a presença de importantes centros de formação de nível universitário (COOKE, 2005).

Foi em Bangalore que se instalou o Instituto Indiano de Ciências, devido à atenção dada à região pela administração britânica. A partir desse investimento público, outros 
vieram, principalmente com o surgimento da Universidade de Bangalore e a instalação de empreendimentos estatais voltados para a tecnologia, especialmente aqueles voltados para a área de defesa (COOKE, 2005).

Ainda que seja possível identificar a presença de uma infra-estrutura favorável ao desenvolvimento de um Sistema Regional de Inovação, para que o cluster finalmente surgisse foi necessário canalizar não somente os novos empreendimentos do setor para a região. Esse foi o papel desempenhado pelos imigrantes que retornavam dos Estados Unidos, trazendo consigo o conhecimento de desenvolvimento de novas tecnologias, passando a aplicá-lo a custos reduzidos na Índia. Pode-se dizer que a principal característica econômica a ter propiciado o desenvolvimento do cluster foi o baixo nível de remuneração do fator humano para os padrões do centro do sistema capitalista. Quando visto à luz das relações de oportunidades aos empreendedores locais, teriam continuado seus empreendimentos no Vale do Silício não fossem os altos custos para operar nos Estados Unidos relativamente ao que poderia ser feito na Índia, assim como em outros países da Ásia. Atrelado ao bom nível dos profissionais formados na região, existência de vontade política para atração de investimentos externos e centros de desenvolvimento e pesquisa de renome, o baixo custo da mão de obra de alto nível alavancou a produção regional, colocando Bangalore entre as regiões mais competitivas do mercado de software e serviços em tecnologia de informação do mundo.

\subsubsection{Como se deram as relações entre governos, instituições de ensino, institutos de pesquisa e empreendedores na concepção e implantação do cluster de Bangalore?}

Para que fosse implantado o conceito de STP, várias medidas foram tomadas para articular os órgãos governamentais de ciência e tecnologia, institutos de ensino e pesquisa e empreendedores, entre elas a criação de comissões específicas para o estudo de viabilidade de implantação de parques tecnológicos em regiões que dispusessem do "talento natural" para tal (BALASUBRAMANYAM; BALASUBRAMANYAM, 2002).

O governo indiano tem como peculiaridade a valorização do profissional de ciência e tecnologia para composição de seus quadros internos. O país possui tradição em ciência de base, tendo grande colaboração para desenvolvimento da matemática, física e química de alto nível através de seus talentosos cientistas. A partir da ciência de base, o cenário educacional indiano se desdobrou para as disciplinas técnicas, principalmente através dos investimentos governamentais em centros de pesquisa e universidades. O surgimento do cluster de 
Bangalore está diretamente relacionado ao empenho governamental em instituir na região um núcleo de aprendizagem em disciplinas técnicas que atingisse a relevância da tradição indiana em ciências básicas. As ações governamentais no intuito de melhorar a educação de nível técnico corroboraram com o retorno dos argonautas (SAXENIAN, 2006) a passo que geraram a possibilidade de utilização da abundante mão de obra a preços locais. A partir de então, houve um alinhamento das partes interessadas em comissões que se destinavam a traçar um planejamento para a reprodução de modelos semelhantes ao encontrado no Vale do Silício por toda a Índia, levando em consideração as particularidades competitivas locais. Governo, empreendedores, centros de pesquisa e instituições de ensino, pelo menos na região de Bangalore, alinharam-se formalmente em busca do objetivo da implantação do STP, que resultou em sucesso dada a relevância e comprometimento das partes envolvidas (COOKE, 2005).

\subsubsection{Qual a relação entre o estabelecimento do cluster e o volume de mão de obra especializada disponível na região?}

A relação entre o surgimento do cluster de Bangalore e o volume de mão de obra especializada disponível é altíssima. A grande vantagem da região está apoiada sobre o custo dos fatores de produção. Como visto anteriormente, o salário médio anual de um profissional de desenvolvimento em ciência e tecnologia em Bangalore flutua entre 4 mil e 6 mil dólares (COOKE, 2005), enquanto nos Estados Unidos essa quantia média pode chegar a mais de 40 mil dólares. Isso significa pagar menos por um profissional de mesma qualidade.

Dada a presença de centros de formação técnica de excelência e diversos institutos de pesquisa, a região forma uma grande quantidade de profissionais especialistas em TI todos os anos, equilibrando a relação de oferta e demanda de mão-de-obra sob o contexto de expansão da base produtiva, mantendo os baixos níveis salariais. O custo de vida da região também é baixo, o que significa a possibilidade de manter um elevado padrão de consumo, ao menos para os padrões locais, mesmo com salários tão baixos. 


\subsubsection{Quais os tipos de relações estabelecidas entre as empresas do cluster de Bangalore e como elas se dão? Existe predominância de algum dos tipos sobre os outros?}

As empresas estão organizadas de forma sinérgica a atender as necessidades uma das outras. A exemplo do que ocorreu no cluster californiano, os empreendedores que retornavam à Índia após longos anos trabalhando em empresas americanas e européias, passaram a observar oportunidades relacionadas ao aproveitamento dos baixos custos dos fatores de produção indiano. Na verdade, diferentemente do que ocorre no cluster americano, quase toda a região de Bangalore está focada no atendimento de uma demanda internacional, haja visto que o mercado local não possui ainda demanda suficiente para absorver tudo o que é produzido pelo cluster (SAXENIAN, 2006). Isso não aconteceu por acaso. A existência do cluster está apoiada na transferência de custos de produção de países centrais do informacionalismo para lugares onde seja possível torna-los menores, e com isso, ganhar competitividade frente ao mercado. A lógica que propiciou o surgimento do cluster como um pólo de excelência é bem diferente da lógica que formou o Vale do Silício. Nos Estados Unidos, há a articulação entre empresas que compartilham de recursos para atendimento do mercado interno e externo, sob a lógica de remuneração local dos fatores de produção. Na Índia, a articulação existente é aquela que favorece o desenvolvimento de produtos que muitas vezes são exclusivamente voltados para o mercado global. A remuneração pela produção de Bangalore é dividida entre os fatores locais e internacionais, tendo em mente que muitas vezes a parte que cabe ao cluster está inserida em uma lógica de remuneração de uma cadeia produtiva em escopo internacional.

Os profissionais de Bangalore também possuem estreitas relações pessoais, fruto do compartilhamento de experiências no exterior (no caso dos profissionais que trabalharam em outros clusters até a década de 1990) e das articulações para estabelecimento de uma cadeia produtiva eficiente. Entretanto, é notório que a cultura local não permite o estabelecimento de um mesmo senso de pertencimento a uma classe de "funcionários de Bangalore" como ocorre no Vale do Silício (SRINIVAS, 2004). De fato, o senso de pertencimento do profissional de TI de Bangalore está mais associado ao mercado global do que ao cluster, pelo simples fato de suas conexões se estenderem muito além das fronteiras do arranjo produtivo, devido a sua experiência como expatriado e da multiplicidade cultural organizacional que vivencia nos empreendimentos locais. Assim sendo, enquanto as relações dos profissionais do Vale do Silício contemplam a idéia de trabalharem para o cluster, e não para as empresas que o 
compõem, em Bangalore os profissionais se vêem trabalhando para o mercado de TI internacional, não somente para o cluster ou para as empresas.

\subsubsection{Há relação de hierarquia, evidenciando um grau de importância de uma empresa frente às outras, nos processos produtivos ou nas diversas relações estabelecidas entre as empresas do cluster?}

Assim como em todos os demais clusters analisados, há a presença de grandes empresas em Bangalore. Entretanto, as relações de hierarquia dadas entre essas e as empresas de menor porte se dão em diversos níveis, não tendo um único agente exercendo influência sobre o processo decisório do cluster. Na verdade, a diferença mais marcante do tipo de relação entre as empresas de Bangalore em relação aos demais clusters analisados tange ao fato de que as conexões de Bangalore estão voltadas para o mundo, ou seja, as empresas localizadas no cluster fazem parte de arranjos produtivos em escala mundial, não se limitando aos arranjos estabelecidos internamente. Esse fenômeno é fruto de um processo que viria a se iniciar no Vale do Silício a partir da década de 1990, quando o cluster já estava consolidado, mas que no caso de Bagalore é evidente desde seu embrião.

Pode-se dizer que as empresas genuinamente indianas de maior porte, como a Wipro, possuem notória expressão nos processos decisórios internos do cluster, mas isso não significa que possua maior relevância do que as demais empresas de grande porte instaladas.

No âmbito das pequenas empresas, tamanha é a importância do cenário externo para suas atividades que as relações estabelecidas internamente chegam a perder relevância (COOKE, 2005). As empresas do arranjo produtivo, por orientarem suas ações locais para o mercado externo, não têm como tendência a competitividade em âmbito regional, mas no âmbito externo - e dada a dimensão do mercado global, essa competitividade fica atenuada diante das possibilidades de negócios existentes. Em contraponto, aproveitam-se da proximidade espacial para exercer a sinergia quando necessário.

\subsubsection{Qual a participação inicial de Bangalore nos volumes de negócios de seus setores?}

O surgimento do cluster de Bangalore veio a reboque de uma necessidade global de barateamento dos custos de produção (COOKE, 2005). Logicamente, há atrelada à 
emergência do cluster uma série de outros fatores que vão da existência de centros de pesquisa e educacionais de excelência à predisposição do governo em instituir um pólo tecnológico de alto nível. Entretanto, para a lógica do capital internacional, a otimização dos recursos - aferindo resultados semelhantes ou melhores com um menor custo associado - foi o que favoreceu o sucesso do cluster. Nesse contexto, os primeiros empreendimentos derivaram de oportunidades observadas anteriormente, a distância, por engenheiros indianos alocados no Vale do Silício. Muitas vezes os empreendimentos se davam sob a existência de contratos já firmados com firmas americanas ou européias. Assim, as start ups surgiam com receita garantida. Isso fez com que o sucesso do cluster, a partir do retorno dos argonautas (SAXENIAN, 2006) fosse quase imediato, o que irrompeu um fluxo de investimentos na região pela percepção do movimento de terceirização de atividades de desenvolvimento, outrora desenvolvidas a custos maiores em países do eixo do sistema capitalista, para zonas de menor custo como Bangalore.

\subsubsection{Como se estabeleceu a rede de relações entre os agentes do pólo de Bangalore (empresas e pessoas) após o início de suas atividades?}

Os empreendedores de Bangalore compartilharam de experiências marcantes que reforçaram suas relações pessoais e profissionais. Muitos dos donos de companhias de TI do cluster se conheceram ainda quando estudavam em centros de formação indianos ou nas universidades americanas, ou mesmo trabalharam juntos em companhias localizadas nos Estados Unidos ou Europa (SAXENIAN, 2006). Dessa forma, o tipo de networking passível de se observar entre os profissionais da região está diretamente relacionado ao esforço desprendido pelos mesmos para transformar suas condições de vida, gerando a sensação de um tipo de pertencimento muito diferente daquele sentido pelos profissionais americanos do Vale do Silício. Enquanto o vínculo dos americanos se sedimenta sobre o compartilhamento de uma cultura voltada para o desenvolvimento regional, o vínculo entre os profissionais indianos de TI, ao menos aqueles que iniciaram seus empreendimentos em Bangalore após retornarem dos Estados Unidos, se justifica pelo ímpeto de desenvolvimento étnico e social, baseado nas agruras e benesses compartilhadas em tempos de vivência em um território estranho, sob uma cultura diferente. 
Pode-se dizer que os elementos culturais adquiridos nas experiências externas também contribuíram para o estabelecimento de uma maior identificação entre os empreendedores indianos, uma vez que retornando ao seu país natal, faziam agora parte de uma classe "argonauta", precursora de novos valores obtidos no Vale do Silício.

\subsubsection{Como se dá o fluxo de transferência de conhecimento entre as empresas de} Bangalore, entre agentes de outros Sistemas Regionais de Inovação e mesmo entre agentes de outros Sistemas Nacionais de Inovação?

As relações informais estabelecidas entre empreendedores possibilitam transferências de informações nos níveis que não se consolidem por acordos formalizados entre organizações. O mesmo que ocorre no Vale do Silício, quando respostas a problemas truncados podem advir de conversas informais entre profissionais fora do ambiente da empresa (SAXENIAN, 2006). Das relações informais emergem propostas de colaboração e, com isso, intensificam-se os fluxos formais de transferência de informação.

No âmbito da transferência de conhecimento tácito, a dinâmica observada em Bangalore é parecida com aquela do Vale do Silício, apoiando-se na rotatividade dos profissionais. Entretanto, o fluxo de profissionais do cluster não ocorre apenas no âmbito regional, uma vez que grande parte das empresas do cluster foi constituída sob fortes laços com o exterior. Muitos dos empreendedores e funcionários de alto escalão das empresas de Bangalore voltaram à região após anos de experiência profissional no Vale do Silício. Quando voltam à Índia, levam consigo conhecimento sobre a tecnologia desenvolvida nos Estados Unidos e sobre as particularidades dos mercados em que as empresas americanas operam.

\subsubsection{Entre os sub-setores da Tecnologia da Informação (software, serviços,} semicondutores, etc.), quais aqueles que obtiveram destaque entre os empreendimentos estabelecidos em Bangalore, tanto por seu volume de negócios como por sua excelência em inovações para o mercado?

O segmento de softwares foi privilegiado pelo desenvolvimento do Software Tecnology Park, sendo este o nicho de mercado de maior expressão para o cluster. Entretanto, a região possui centros de desenvolvimento de projetos de semicondutores, além de possuir 
expressão internacional em serviços de suporte técnico a usuários de sistemas em nível global. Dos STP instalados na Índia, o de Bangalore é o mais expressivo, sendo responsável por mais de $50 \%$ das exportações de software de todo a Índia.

\subsubsection{Qual a importância do poder público e da legislação vigente para a manutenção do pólo tecnológico?}

O governo indiano propiciou a formação do parque tecnológico de Bangalore através do investimento direto em infra-estrutura e aprovação de uma legislação que incentiva a presença de empresas de base tecnológica na região. Por conta da legislação, empreendedores que atuem sob as regras do STP, por exemplo, possuem isenção de 100\% do imposto de renda por dez anos, além de outras facilidades para operar na Índia (YUE, 2001). Isso permite que as empresas possam dedicar a parte da receita que remuneraria o Estado para a expansão dos negócios, estabelecendo novas conexões internas e externas, ampliando sua participação sobre o mercado e intensificando as relações comerciais já existentes.

O governo também é responsável, através de parcerias com a iniciativa privada, pela ampliação do número de vagas em institutos técnicos e universidades da região onde o cluster está instalado. Isso beneficia milhares de estudantes que passam a se inserir todos os anos em um dos mercados de maior expansão no mundo globalizado, além de contribuir para a manutenção do valor dos salários pagos pela disponibilidade de oferta de mão-de-obra especializada.

\subsubsection{Qual a posição sócio-econômica da região onde o cluster de Bangalore está estabelecido frente ao padrão nacional e aos padrões das regiões dos demais pólos tecnológicos do mesmo setor (limitando-se aos estudados)?}

O cluster de Bangalore está situado em uma região que, quando comparada com o padrão indiano, pode ser considerada privilegiada, mas quando confrontada com a realidade do Vale do Silício e dos clusters brasileiros, não possui grandes vantagens econômicas. Principalmente no que tange à distribuição da renda, Bangalore ainda está aquém do desenvolvimento social contemplado no Vale do Silício, e até mesmo da região de São Carlos e Campinas. 
Apesar da ausência de equidade social, a região sempre dispôs de recursos para investimento em infra-estrutura de base no passado, o que possibilitou o surgimento do cluster, ainda que essa estrutura fosse restrita a uma pequena parte da população. Entretanto, o crescimento da indústria de TI foi maior do que a infra-estrutura instalada, o que gerou diversos inconvenientes como falta de energia e problemas de distribuição de água (SRINIVAS, 2004). A maioria dos investimentos na região estão divididos entre capital externo, canalizado por empresas de capital de risco, capital próprio das empresas locais de grande porte como Infosys e Wipro, e capital de empresas multinacionais que investem em plantas produtivas no cluster de Bangalore. O governo também contribui para a disponibilidade de recursos através de linhas de crédito especiais para os empreendedores de tecnologia (COOKE, 2005).

\subsubsection{Há relação entre os fatores de desenvolvimento social da região com o pólo tecnológico?}

Várias iniciativas foram tomadas pelas empresas instaladas no pólo tecnológico de Bangalore para reduzir os impactos da inequidade social, uma característica própria de todas as regiões da Índia. Além dos programas sociais suportados por gigantes nacionais como a Wipro, os argonautas procuram influenciar os governos locais no intuito de melhorar as condições de vida para a parte da população que não é beneficiada diretamente pela presença do cluster. A questão social ainda é muito preocupante em Bangalore, mas pode ser descrita como mais amena se comparada com o resto da Índia (SRINIVAS, 2004). Entretanto, grande parte da população ainda vive na pobreza, pois as benesses do desenvolvimento econômico local não são percebidas por todos, fruto de uma cultura ainda muito próxima do antigo regime de castas (KAMDAR, 2008). Muito tem sido feito, sob premissas oriundas dos anos de convivência em um ambiente de caráter desenvolvimentista como o Vale do Silício, entretanto ainda há muito a se fazer, principalmente no que tange à mudança da vontade política em transformar o desenvolvimento econômico em desenvolvimento social (SAXENIAN, 2006). 


\subsubsection{Como Bangalore se integra com o desenvolvimento de pesquisa científica da região} que ocupa? Qual sua participação no estabelecimento de implementos educacionais da região?

A Índia já possuía ampla tradição em ciência de base antes mesmo do surgimento das primeiras empresas de informática no país. As instituições de ensino de Bangalore fazem parte desse cenário, sob uma cultura que sempre beneficiou a prospecção de novos conhecimentos científicos. Entretanto, o acesso a esse tipo de conhecimento através da educação formal não era abrangente. Muitas crianças indianas chegam à fase adulta sem nunca ter ido à escola, o que contribui o baixo índice de alfabetização adulta do país, cerca de apenas 61\% (UN, 2007). A região de Bangalore sofre menos com o problema de acesso ao ensino básico, mas esse ainda é um problema. A realidade do cluster é antagônica, havendo a presença de uma boa parte da população com pós-graduação convivendo com outra grande quantidade de pessoas que nunca foram à escola (KAMDAR, 2008).

Os problemas relacionados ao acesso à educação não podem ser justificados pela ausência de uma legislação que proteja o direito ao ensino de qualidade, pois há muito tempo as leis indianas promovem a ampliação do conhecimento a todas as classes sociais, entretanto ainda há muito pouca vontade política para que as leis sejam cumpridas a risca (KAMDAR, 2008). A lógica que promoveu o sucesso do cluster de tecnologia não está necessariamente atrelada ao desenvolvimento social, pelo contrário, se beneficia da existência de um exército social de reserva que possa ser, futuramente, convertido em mão-de-obra especializada de baixo custo para servir à necessidade de competitividade do pólo tecnológico.

Apesar das disparidades quanto ao acesso à formação, é notória a diferença da região de Bangalore para o resto do país, o que leva aos autores que estudam o tema verificarem que Bangalore não é, em hipótese alguma, uma representação exata do que é a Índia contemporânea. Pelo contrário, a realidade de Bangalores está muito mais próxima da realidade dos pólos industriais chineses do que do interior do país (SAXENIAN, 2006).

A pesquisa científica da região é orientada para muitas áreas, não sendo necessariamente atrelada às necessidades das empresas da região. Apesar de haver convênios estabelecidos entre grandes indústrias de semicondutores, produtores de softwares e desenvolvedores de produtos de tecnologia de informação em geral, os centros de pesquisa e ensino tecnológico da região também estão conectados às demandas do aparato de defesa do governo indiano e de setores instalados em outras regiões do país. A integração entre universidades, centros de pesquisa e empresas existe e pode ser considerada muito útil para a 
manutenção do cluster, pelo menos no que se refere à formação de pessoal especializado e resolução de problemas referentes à geração de inovação de produtos e processos, entretanto a produção científica local não está direcionada apenas ao que é demandado pelo mercado de TI (ASHWANI; VIJAYABASKAT, 2005). 


\section{RESULTADO DA PESQUISA DOS CLUSTERS NACIONAIS}

A maior parte dos resultados da pesquisa dos clusters nacionais é oriunda da pesquisa de campo realizada através da utilização do instrumento de pesquisa do Anexo B. Conforme delimitado no tópico 3.4.2., foram abordados os representantes dos órgãos administrativos dos pólos tecnológicos abordados. A Ciatec, Companhia para o Desenvolvimento do Pólo de Alta Tecnologia de Campinas, teve como representante o Sr. Décio Sirbone Jr, diretor da instituição e responsável pelas empresas nascentes do parque tecnológico. O Parqtec, parque tecnológico de São Carlos, foi representado frente à pesquisa por seu diretor-presidente, Prof. Dr. Sylvio Goulart Rosa e sua encarregada de imprensa, Geziellen Silva.

Para que houvesse maior compreensão sobre a posição da administração pública frente aos desdobramentos da instalação da planta produtiva de semicondutores proposta pelo consórcio Encalso-Symetrix (ANTUNES, 2008), foi entrevistado também o vice-prefeito e Secretário de Ciência e Tecnologia de São Carlos, Sr. Emerson Leal.

Os instrumentos de pesquisa para prospecção de informações dos clusters nacionais e internacionais são idênticos, tanto no encadeamento quanto no conteúdo das questões levantadas. Entretanto, a metodologia de trabalho é muito distinta. No caso dos clusters internacionais, o pesquisador realizou uma extensa pesquisa bibliográfica para identificar todas as peculiaridades referentes à estruturação de relações entre empresas e agentes dos clusters abordados. Após o levantamento bibliográfico, o pesquisador pôs-se a buscar respostas paras as questões levantadas no instrumento de pesquisa (Apêndice A), levando em consideração a percepção de diversos autores e do próprio pesquisador sobre o tema. Uma vez configurado o modelo de solução indireta, intermediada pelo pesquisador, às questões levantadas no instrumento de pesquisa, em busca da solução do problema de pesquisa levantado, seria necessário equiparar o método de trabalho em relação aos clusters nacionais. Entretanto, devida à ausência de bibliografia para a obtenção das informações necessárias para responder às questões levantadas em busca de uma solução coerente ao problema de pesquisa, foi necessário buscar essas informações em campo, através das referidas entrevistas. Para compor as respostas ao roteiro sugerido como instrumento de pesquisas, foram abordados livremente durante a interpelação dos respondentes diversos temas correlatos às questões levantadas. Assim, o pesquisador pode obter uma impressão mais completa sobre os tópicos abordados, no intuito de suprir a ausência de literatura direcionada à análise das relações internas em clusters de tecnologia da informação nacionais. 


\subsection{Respostas ao instrumento de pesquisa sobre Campinas}

O cluster de Campinas possui uma condição de excelência frente aos demais pólos tecnológicos nacionais, não apenas por sua infra-estrutura, mas também por conta da relevância de mercado dos agentes de inovação que compartilham de seu espaço. O volume de empreendedores no pólo tecnológico não pode ser comparado com o que é percebido nos clusters internacionais. Entretanto, é possível verificar peculiaridades quanto ao perfil dos empreendedores, em sua maioria alunos dos cursos de graduação e pós-graduação da Unicamp, segundo informações aferidas pela entrevista com o diretor Décio Sirbone Jr.

Além da característica diferenciada quanto ao perfil do empreendedor, o cluster de Campinas conta com a presença de algumas grandes empresas alocadas, como a HewlettPackard e a Lucent. Além do que foi aferido por meio de entrevista, o pesquisador pode perceber outras particularidades que ajudaram a elucidar as questões abordadas no instrumento de pesquisa através das duas visitas realizadas ao cluster e de sua experiência anterior como funcionário de uma instituição financeira alocada no parque tecnológico. Isso contribuiu para ampliar o conhecimento sobre a dinâmica as relações entre os agentes do cluster, de forma a reformular aquilo que se tinha observado pela pouca bibliografia disponível sobre o tema no escopo daquela região.

\subsubsection{Como se deu o processo histórico de desenvolvimento do pólo tecnológico de Campinas?}

Segundo o Sr. Décio Sirbone Jr., desde 1985 alguns professores da Unicamp se dirigiram ao prefeito de Campinas com um projeto para implantação de um parque tecnológico, aos moldes dos projetos que estavam aparecendo ao redor do mundo naquela mesma época. No mesmo ano, o Governo Federal procurava um ambiente para instalar o centro de pesquisa do Sistema Telebrás. Com um acordo realizado entre a prefeitura de Campinas (gestão do então prefeito Magalhães Teixeira) e o Governo Federal, a cidade receberia o investimento destinado ao centro da Telebrás em troca de destinar uma região de oito milhões de metros quadrados ao redor da Unicamp para a constituição de um parque tecnológico. Desde então foram instituídos por decreto os Pólos I e II de Alta Tecnologia de 
Campinas, tendo sido instalado no Pólo II a base da Telebrás, que mais tarde, após a privatização do sistema de telefonia brasileiro, daria espaço à Fundação CPqD.

A área destinada ao parque tecnológico não foi desapropriada. A região era formada por fazendas com, ao todo, oito proprietários, que assinaram acordos com a prefeitura de Campinas para loteamento da região e destinação das áreas apenas para instalação de companhias de tecnologia, sendo proibida qualquer atividade diferenciada.

A partir de 1996, a Ciatec passou a coordenar as atividades desenvolvidas no Pólo Tecnológico em busca de atrair empresas para aquele que já era chamado o "futuro Vale do Silício Brasileiro". Após várias mudanças de governo, percebeu-se que de 1986 a 2001 houve muito pouca vontade política de fazer o Pólo Tecnológico crescer. Apesar disso, algumas empresas já haviam se instalado na área destinada ao parque, e muitos outras do segmento de TI na região de Campinas. A Motorola, por exemplo, instalou-se em Jaguariúna, após várias consultas à Ciatec para estabelecer sua base operacional no Pólo Tecnológico. A escolha por Jaguariúna foi justificada pela empresa pela boa recepção que o poder político da cidade vizinha deu às idéias da empresa. Segundo o entrevistado, isso mostra que a vontade política em transformar Campinas em um grande centro de TI era incipiente por parte do poder público municipal, mas instituições muito importantes para a tecnologia nacional já estavam instaladas, como o Laboratório Sincrotron, a Fundação CPqD e o Centro de Tecnologia de Informação do governo federal.

Apenas em 2001, com a posse do prefeito Toninho do PT, houve a retomada das atividades que visavam a expansão do pólo tecnológico. Entretanto, o prefeito foi assassinado sob circunstâncias ainda não totalmente esclarecidas e o projeto de expansão mais uma vez entrou em recesso, devido à falta de interesse da gestão de sua substituta, a vice-prefeita Izalene.

A partir de 2005, com uma nova gestão municipal, o parque tecnológico voltou a ser tema da pauta política, com a ampliação das ações que visam o desenvolvimento do empreendedorismo tecnológico na região e incentivo às indústrias de grande porte para que se instalem no parque. Em 2009 houve duas propostas de grandes empresas para a instalarem plantas de desenvolvimento na região, cujos nomes não podem ser divulgados por acordos de confidencialidade estabelecidos com a Ciatec. Essas empresas devem se instalar até 2011, gerando mais empregos para a região no setor de TI.

A criação do parque tecnológico veio a reboque da percepção de uma "vocação" da região para abrigar empresas do setor de tecnologia de ponta. Com a instalação da IBM e Compaq nas décadas de 1970 e 1980, além da disponibilidade de uma universidade de alta 
relevância na formação de profissionais das áreas de engenharia e computação, a Unicamp, era possível notar que a região poderia, em breve, despontar como um dos maiores clusters de tecnologia do país. Entretanto, apenas com a instalação da Telebrás é que se pode concretizar o modelo de Sistema Regional de Inovação apoiado sobre a tríade de instituições de ensino, centros de pesquisa e empresas. O centro de pesquisas da Telebrás, que mais tarde se tornaria a Fundação $\mathrm{CPqD}$, foi responsável pelo aprimoramento das telecomunicações no Brasil durante mais de dez anos, trabalhando cooperativamente com empresas do setor de TI de todo o país e estabelecendo parcerias com diversas universidades e pesquisadores brasileiros.

\subsubsection{Quais as características econômicas que propiciaram o surgimento do cluster na região de Campinas?}

Campinas é uma das cidades mais ricas do Estado de São Paulo, mas sofre com os problemas sociais derivados da má distribuição de renda. A região conta com a presença de várias indústrias, além de se beneficiar da relativamente pouca distância da capital do estado. No início das atividades do parque tecnológico, Campinas era uma cidade sem muitos problemas sociais e uma grande receita derivada da atividade industrial e comercial. Várias empresas do setor financeiro também operavam na região, o que a tornava um canal de distribuição de recursos para o interior do estado. Sua importância política também era relevante, ao passo que sua importância econômica a tornava a segunda cidade do estado mais atraente para se investir, perdendo apenas para a capital (CANO, BRANDÃO, 2002).

A disponibilidade de mão de obra qualificada e boa infra-estrutura atraíram as indústrias até os dias de hoje, o que expandiu as condições econômicas da cidade e contribuiu para o aumento dos investimentos públicos e privados na região, principalmente em melhorias dos sistemas de transportes e tráfego.

\subsubsection{Como se deram as relações entre governos, instituições de ensino, institutos de pesquisa e empreendedores na concepção e implantação do cluster de Campinas?}

A Unicamp foi precursora do projeto de implantação de um parque tecnológico em Campinas, mas outros movimentos da iniciativa privada contribuíram para que a instituição pressentisse a vocação da região para se tornar um aglomerado de empresas do setor de TI. 
Primeiramente, a universidade articulou-se com o governo municipal e este trouxe o projeto ao âmbito federal. Dessa articulação foi possível a instalação dos centros federais de tecnologia da Telebrás e o ITI (Instituto Tecnológico de Informática), que foi rebatizado no final da década de 1990 por CTI. Assim, é possível dizer que o poder público e a principal instituição de ensino da região estavam bem alinhados para a implantação do parque tecnológico. Entretanto, ainda havia que se contar com a participação efetiva das empresas.

Pode-se dizer que as poucas grandes empresas que se instalaram na região na época de implantação do parque tecnológico o fizeram pela disponibilidade de recursos humanos e proximidade dos centros de pesquisas federais e unidades de pesquisas internas da Unicamp.

A iniciativa privada não contribuiu em demasia com a formação dos parques administrados pela Ciatec, mas contribuíram para o estabelecimento de uma vocação natural da região em abrigar empresas de cunho tecnológico. De fato, a vocação de Campinas não é propriamente de celeiro de indústrias de tecnologia, mas de um parque industrial que contemple diversos setores. A presença de empresas do porte de IBM, Compaq e Lucent permitem dizer que entre os muitos setores instalados na região, o de TI possui considerável expressão.

Outra iniciativa privada que vem a somar na identificação da região como um cluster de tecnologia de informação é a iniciativa do grupo DPaschoal em estabelecer um condomínio privado de empresas na Rodovia Anhanguera, com cerca de 800 mil metros quadrados, denominado Techno Park. Esse empreendimento não conta com a estrutura oferecida pelos pólos administrados pela Ciatec, mas é voltado à locação de facilidades para empresas de tecnologia de ponta, o que contribui para o fortalecimento do Sistema Regional de Inovação. Apesar de não estar alinhado com a proposta de estabelecimento do parque tecnológico abordado pela pesquisa, o Techno Park faz parte do cluster da região de Campinas, por estar localizado em seu escopo territorial e contribuir para a presença de um número maior de empresas inovadoras.

\subsubsection{Qual a relação entre o estabelecimento do cluster e o volume de mão de obra especializada disponível na região?}

A presença de uma universidade de alta expressão e produção científica como a Unicamp é muito importante para a formação de mão-de-obra qualificada para o trabalho nos postos de pesquisa e desenvolvimento da região. Muitos dos projetos de desenvolvimento de 
produtos que ocorrem nas empresas do cluster são executados em parceria com a universidade, aproveitando-se do alto nível dos pesquisadores vinculados a ela, verbas do governo do estado e instalações modernas.

Entretanto, a mão-de-obra advinda da universidade não é a única a disputar as vagas do cluster. Muitos profissionais atuantes em companhias da região tiveram formação em outras regiões do país, sendo possível encontrar alguns estrangeiros entre eles. Pelo menos nas empresas multinacionais, é possível encontrar engenheiros e administradores expatriados, que buscam alinhar a cultura organizacional local com aquela praticada na matriz. A região de Campinas não depende apenas da mão-de-obra gerada na região, pois sua localização estratégica permite buscar profissionais da capital e do interior do estado, que muitas vezes trabalham no cluster e moram a até cem quilômetros do parque tecnológico. A conveniência de estar posicionada em meio à melhor malha viária do país permite que Campinas desfrute de uma situação logística que a beneficia na aquisição de recursos humanos formados em diversos outros pólos de formação tecnológica do estado.

\subsubsection{Quais os tipos de relações estabelecidas entre as empresas do pólo de tecnologia e como elas se dão? Existe predominância de algum dos tipos sobre os outros?}

As relações entre as empresas do pólo tecnológico de Campinas não se baseiam na constituição de uma rede produtiva onde haja o encadeamento dos recursos de diversas organizações voltados para a composição de um produto ou serviço final. São poucas as empresas que estabelecem parcerias produtivas com outras empresas do cluster. Segundo o Sr. Décio Sirbone Jr., é muito mais comum assistir ao estabelecimento de parcerias com empresas de fora do país do que com empresas localizadas no parque tecnológico ou mesmo na região de Campinas.

Durante a atividade em campo, o pesquisador se deparou com o caso de uma das relações entre empresas ocorridas no interior do cluster, na qual uma empresa nascida no parque tecnológico de grande porte tinha uma empresa de pequeno porte vizinha como fornecedora de um determinado insumo eletrônico. Em pouco tempo a empresa de grande porte adquiriu a menor, incorporando a linha de produção do insumo às suas atividades. A incorporação, técnica negocial que remonta à Era Industrial do capitalismo, faz com que haja a tendência de constituição de redes mononucleadas, ou mesmo a extinção das redes de organizações, substituídas por uma grande rede interna. 
Os motivos apontados pelo entrevistado para o baixo número de relações estabelecidas entre as empresas do cluster são a falta de integração entre empreendedores e profissionais e a necessidade de proteção dos conhecimentos desenvolvidos no âmbito da empresa. Segundo o diretor da Ciatec, a instituição promove encontros mensais entre empreendedores e diretores de empresas consolidadas na região, mas poucas parcerias surgiram desde intento. Percebe-se uma dificuldade de integração dada por uma cultura local que privilegia muito mais a competição do que a sinergia, deixando a cooperação apoiada apenas sobre a temática de compartilhamento dos custos relacionados à ocupação do espaço físico, tais como disponibilidade de mão-de-obra e infra-estrutura logística.

\subsubsection{Há relação de hierarquia, evidenciando um grau de importância de uma empresa frente às outras, nos processos produtivos ou nas diversas relações estabelecidas entre as empresas do cluster de Campinas?}

Primeiramente, não há um grande número relações estabelecidas no cluster de Campinas. As grandes empresas estabelecem algumas relações de cunho produtivo com fornecedores, muitas vezes trazendo-os para seu espaço físico, mas esses geralmente não surgiram no cluster, apenas se deslocam para lá por conta de contratos firmados com seus clientes de grande porte. Segundo o respondente, é muito mais comum encontrar relações estabelecidas com empresas de fora do cluster do que de dentro. Quando observada a constituição de algum tipo de relação produtiva, é comum a identificação do tipo fornecedorcliente, onde a empresa cliente possui maior relevância e o fornecedor desvia a maior parte de sua produção para o atendimento das necessidades do cliente, geralmente uma empresa de grande porte.

No que tange ao desenvolvimento de pesquisas, a Fundação CPqD é a instituição de maior expressão da região, sendo responsável direta pela criação de alguns start ups de sucesso do cluster, detendo a tecnologia que propiciou o surgimento dos negócios. Não fosse a presença do centro de pesquisas, boa parte das descobertas que propiciaram inovações nos produtos produzidos no cluster e em outras empresas do território nacional não teria acontecido. Outra instituição de notória importância é a Unicamp, que alinhada ao CPqD, desenvolve boa parte das pesquisas estabelecidas no cluster, em parceria direta com as empresas sob o auspício de instituições de fomento como a Fapesp. 
Percebe-se que as relações estabelecidas no interior do cluster têm quase sempre como agentes centrais a universidade e o centro de pesquisas. De fato, as empresas se articulam com essas instituições com maior freqüência, mas raramente se articulam entre si. Diferentemente do que ocorre no Vale do Silício, as redes produtivas em torno do desenvolvimento de inovações incluem quase sempre uma única empresa - e quando incluem mais de uma, apenas uma do cluster - conectada ao centro de pesquisa ou à universidade.

\subsubsection{Qual a participação inicial do cluster de Campinas nos volumes de negócios de seus setores?}

Nenhuma das empresas nativas do cluster ou suas subsidiárias de multinacionais detêm a maior participação nos setores em que atuam no nível global. A maior relevância pode ser dada às instituições identificadas como centrais, que são a Unicamp e o CPqD, mas apenas no escopo nacional. Inicialmente, o pólo tecnológico não movimentava grandes receitas, podendo dar maior destaque para as atividades desempenhadas pelas empresas de grande porte instaladas, tais como a HP. Entretanto, sua participação dentro do conjunto de subsidiárias internacionais da corporação não está acima da média. Pode-se concluir que as empresas alocadas no cluster não possuem relevância exacerbada nos setores em que atuam, exceto aquelas que são únicas detentoras do tipo de tecnologia com que trabalham, caso identificado em três empresas da região, uma delas alocada no Pólo II de Alta Tecnologia.

\subsubsection{Como se estabeleceu a rede de relações entre os agentes do pólo de tecnologia de} Campinas (empresas e pessoas) após o início de suas atividades?

A rede de relações se estabeleceu em torno da Unicamp ou do $\mathrm{CPqD}$, sendo que poucas relações foram estabelecidas entre as empresas. Segundo o entrevistado, apesar dos intentos da administração do parque tecnológico em incentivar as conexões entre os agentes do cluster, a cultura organizacional típica da região privilegia o sigilo do que é praticado internamente em cada empresa, interrompendo o fluxo de informações e reduzindo as possibilidades de estabelecimento de parcerias. Pode-se dizer que as poucas relações estabelecidas não representam uma tendência, mas o desdobramento da tendência principal que é o estabelecimento de relações, especialmente para o desenvolvimento de inovações, 
com a universidade e com o centro de pesquisas, principalmente para se aproveitar da capacidade instalada dessas instituições e dos convênios firmados entre elas e o governo federal para aporte de verbas destinadas ao desenvolvimento de novas tecnologias.

\subsubsection{Como se dá o fluxo de transferência de conhecimento entre as empresas do cluster de} Campinas, entre agentes de outros Sistemas Regionais de Inovação e mesmo entre agentes de outros Sistemas Nacionais de Inovação?

O eixo formal de transferência de conhecimento no cluster de campinas tem como alicerce as relações estabelecidas entre Unicamp, CPqD (ou outra unidade de pesquisa alocada na região) e empresas. As empresas possuem poucas relações entre si, o que dificulta o tráfego de informações entre organizações. Geralmente, a intermediária dessas relações é a Unicamp, principalmente no que se refere ao fluxo informal.

No que tange ao conhecimento tácito, é possível identificar um baixo nível de intercâmbio de profissionais entre as organizações instaladas, sendo que na maioria das vezes a transferência por socialização ocorre no âmbito das parcerias estabelecidas com a Unicamp ou com os centros de pesquisa instalados na região.

As parcerias encontradas no estudo da região geralmente apontam para elementos alocados fora do cluster, o que significa dizer que a maior parte das relações estabelecidas entre empresas se dá no sentido de estruturar uma rede produtiva que extravase os limites do pólo tecnológico, mantendo apenas um (e em raros casos mais de um) de seus nós no interior do cluster. Portanto, é possível dizer que há uma nítida orientação das atividades de desenvolvimento e pesquisa para a cooperação em um Sistema Nacional de Inovação, que muitas vezes sobrepõe às relações estabelecidas no âmbito do Sistema Regional - embora esse seja relevante no âmbito das relações empresa-Universidade.

\subsubsection{Entre os sub-setores da Tecnologia da Informação (software, serviços,} semicondutores, etc.), quais aqueles que obtiveram destaque entre os empreendimentos estabelecidos no cluster de Campinas, tanto por seu volume de negócios como por sua excelência em inovações para o mercado? 
A distribuição das empresas pelos setores que operam é relativamente equilibrada no cluster, mas as empresas de alguns setores específicos conseguiram maior relevância de mercado. É o caso do setor de softwares, por conta da presença do instituto de desenvolvimento de softwares Softex, e de montagem e desenvolvimento de equipamentos para telecomunicações, setor beneficiado pelo expertise do CPqD. Segundo o diretor Décio Sirbone Jr., já é possível verificar a expansão do setor de serviços no interior do cluster, principalmente relacionados ao desenvolvimento de produtos e serviços exclusivos na área de gestão tecnológica.

\subsubsection{Qual a importância do poder público e da legislação vigente para a manutenção do pólo tecnológico?}

Segundo o Sr. Décio Sirbone Jr., o poder público tem tido muito pouca participação nas atividades desempenhadas no cluster desde sua instituição a partir da segunda metade da década de 1980. Da área destinada ao parque tecnológico, ainda há muito pouca ocupação, o que gerou problemas com seus proprietários, que vem sendo impedidos de obter ganhos com o loteamento das terras por não haver interesse de empresas de tecnologia em se fixarem na região. Uma vez que as áreas só podem ser ocupadas por empresas de tecnologia, os proprietários não têm outra alternativa senão esperar que haja interesse de investidores e empreendedores em estabelecer negócios no cluster.

Entretanto, a legislação vigente garante a preservação da área destinada ao parque tecnológico, sendo que essa não poderá ser ocupada para outros intentos diferentes da instalação de empresas de base tecnológica. Contudo, a legislação também contribui para o desinteresse pela área pela instituição de um tamanho mínimo de lote muito acima das pretensões da maioria das empresas que procuram a Ciatec para se instalar na região. Esse problema também é encontrado pelas empresas que se graduam em uma das incubadoras do parque e não conseguem permanecer na região por conta do tamanho mínimo dos lotes a serem adquirido ser muito superior às suas necessidades e recursos disponíveis. Isso às empurra para outras regiões do estado, e até mesmo para outras regiões do país, ponto que contribui para a cisão das relações entre empresas e prejudica a consolidação do Sistema Regional de Inovação. Segundo o entrevistado, alguma das empresas incubadas que se graduam chegam a fechar por não conseguirem se manter na região. 
A impressão que a legislação consolidada sobre o parque tecnológico passa é de que este foi pensado para abrigar apenas empresas de grande porte, o que vai contra os preceitos de desenvolvimento de clusters tidos como referência no mundo todo. Os empreendedores locais geralmente partem de uma situação de baixa disponibilidade de recursos, não podendo arcar com os enormes custos de aquisição ou aluguel de instalações no parque tecnológico. Esse problema começa a ser equacionado com iniciativas como a do Techno Park, trazendo à região o conceito de condomínio de empresas. Entretanto, a idéia de condomínio de empresas praticada na região de Campinas se fixa no desenvolvimento de empreendimentos mobiliários voltados para as empresas de tecnologia, não considerando o estabelecimento de relações entre os agentes locais, mas apenas a sua aglomeração em um mesmo espaço, objetivando a cooperação frente aos custos relacionados à ocupação territorial.

\subsubsection{Qual a posição sócio-econômica da região de Campinas frente ao padrão nacional e aos padrões das regiões dos demais pólos tecnológicos do mesmo setor (limitando-se aos estudados)?}

Campinas detém o terceiro maior PIB do Estado de São Paulo, o que a coloca entre as cidades mais produtivas do país. Além de uma boa situação econômica, a infra-estrutura social de Campinas está à frente da média nacional, com boa disponibilidade de instituições de ensino de base e instituições de saúde básica. Segundo o IBGE (2008), em relação ao estado de São Paulo, a cidade de Campinas teve em 2007 um PIB de cerca de 27 bilhões de reais, ficando atrás apenas de Guarulhos e da capital. Apesar do bom desempenho econômico, há regiões carentes na cidade, e o índice de criminalidade está entre os maiores do país. Entretanto, segundo o Sr. Décio Sirbone Jr., a atual gestão municipal está trabalhando para ampliar a infra-estrutura para atendimento da população nas questões relativas à saúde, educação e segurança pública, que já é bem mais eficiente do que na maior parte do Brasil. 


\subsubsection{Há relação entre os fatores de desenvolvimento social da região com o pólo tecnológico?}

Não há relação direta entre o pólo tecnológico ou suas empresas e os fatores de desenvolvimento social da região. As iniciativas de melhoria das condições sociais implementadas pelas empresas do segmento de TI são poucas e de resultados não conclusivos.

Entretanto, é possível dizer que as receitas geradas pelo setor de TI contribuem para o desenvolvimento de políticas públicas voltadas para o social através da arrecadação de impostos. Apesar do interesse das empresas instaladas em melhorar a condição social da região, não há iniciativas que sejam relevantes no sentido de oferecer melhores condições de vida aos moradores não envolvidos com a atividade do cluster.

Apesar da nítida desigualdade social, a boa infra-estrutura é um dos motivos que legitimou a instalação das empresas na região, não somente aquela responsável pela logística operacional, mas a infra-estrutura educacional e de saúde, fatores de desenvolvimento social que estão entre os melhores do país.

\subsubsection{Como o pólo tecnológico de Campinas se integra com o desenvolvimento de pesquisa científica da região que ocupa? Qual sua participação no estabelecimento de implementos educacionais da região?}

Muitas das pesquisas desenvolvidas no âmbito das empresas são realizadas em parceria com a Unicamp e com os institutos de pesquisa da região. Segundo o Sr. Décio Sirbone Jr., a parceria das empresas com a Unicamp contribui para que a universidade atinja receitas através das quotas das patentes geradas, o que se desdobra em maiores recursos para a melhoria das condições de ensino e pesquisa na instituição.

\subsection{Respostas ao instrumento de pesquisa sobre São Carlos}

O instrumento de pesquisa de São Carlos contou com uma formulação de respostas derivada de três entrevistas a agentes ligados ao cluster, sendo o mais importante deles o fundador e atual presidente do Parqtec, o Prof. Dr. Sylvio Goulart Rosa Jr. Além do presidente do Parqtec, colaboraram com a pesquisa a encarregada de imprensa, Sra. Geziellen 
Silva e o vice-prefeito e secretário de ciência e tecnologia de São Carlos, Sr. Emerson Leal. Os resultados apresentados são, na verdade, a composição obtida pelas três entrevistas, combinada à percepção do autor sobre a realidade interna do parque tecnológico obtida nas duas visitas realizadas às instalações do Parqtec em São Carlos.

O cluster de São Carlos tende a ser ampliado com a geração de um novo parque tecnológico, iniciativa do grupo Encalso-Damha, responsável por inúmeros empreendimentos imobiliários na região.

\subsubsection{Como se deu o processo histórico de desenvolvimento do pólo tecnológico de São}

\section{Carlos?}

Segundo o Prof. Dr. Sylvio Goulart Rosa Jr., o Instituto de Física de São Carlos, pertencente à Universidade de São Paulo, teve vital importância para o desenvolvimento do cluster, a partir da elaboração do projeto que se desdobrou na criação do Parqtec. Na verdade, São Carlos já possuía a Escola de Engenharia de São Carlos, importante instituição de formação de profissionais do interior do estado, mas ainda não havia um movimento de empreendedorismo ligado às atividades da faculdade. Foi o Instituto de Física que, segundo o Prof. Sylvio, acabou por impulsionar o surgimento das primeiras empresas de tecnologia da região, por conta do perfil de seus acadêmicos, voltados para o desenvolvimento local.

O empreendedorismo dos físicos de São Carlos se inicia na área acadêmica, através de convênios que estabeleceram com a Fundação Fulbright e a Marinha Americana para instalar os primeiros laboratórios de alta tecnologia da região, voltados para o desenvolvimento de experimentos no âmbito da academia. Os convênios estabelecidos vinham do ímpeto de ser competitivo no âmbito acadêmico com os grandes centros de pesquisa do mundo. As relações estabelecidas com o exterior tiveram estofos exclusivamente acadêmicos até 1984.

A partir de 1984, percebeu-se a vontade de alguns dos integrantes dos corpos docentes da Escola de Engenharia e do Instituto de Física de São Carlos em formar empresas para exploração comercial das descobertas realizadas nos laboratórios da universidade. O intuito dos acadêmicos ganhou forças quando alinhado com a percepção de lideranças políticas da época de que aquela poderia ser a oportunidade para tornar São Carlos um centro de 
referência nacional na produção de tecnologia, o que somente poderia acontecer se houvesse capacidade local para a instalação de indústrias de alta tecnologia.

Em 1984, o Prof. Sylvio Goulart Rosa Jr., sob o auspício do CNPq, criou a Fundação Parqtec, uma entidade que visa à administração daquele que viria a ser o Pólo Tecnológico de São Carlos. Inicialmente, o Parqtec tinha como meta gerar condições para que novas empresas tecnológicas pudessem emergir, baseadas nas descobertas dos docentes e pesquisadores das universidades e centros de pesquisa da região. São Carlos conta com duas grandes universidades instaladas, um dos campi da Universidade de São Paulo no interior (que abriga cursos de engenharias, química e física) e a Universidade Federal de São Carlos, fontes de mão-de-obra especializada, inovações tecnológicas e recursos para pesquisas através de convênios com fundações como a Fapesp. A idéia inicial era incentivar o empreendedorismo, através de recursos para que os agentes de inovações ligados às universidades pudessem transformá-las em novos produtos. Dessa iniciativa foi gerada uma rede de incubadoras, denominada Parqtec.net, com sede na cidade de São Carlos e unidades nas cidades de Leme, Rio Claro e Botucatu. O Parqtec fundou a primeira incubadora de empresas da América Latina em 1985.

Em São Carlos, três incubadoras focadas em diferentes projetos são administradas hoje pelo Parqtec em um prédio dividido em módulos. As incubadoras oferecem aos empreendedores uma cesta diversificada de serviços, que vão de consultoria a serviços de busca bibliográfica.

Em 1994, o governo municipal de São Carlos repassou ao Parqtec uma área de 164 mil metros quadrados que serviria para a implantação do Science Park, o Parque Tecnológico de São Carlos. A implantação do Parque Tecnológico se iniciou em 2002, com apoio da FINEP, Sebrae e Governo do Estado de São Paulo.

Além das duas universidades a cidade conta também com dois centros de pesquisa da Embrapa. A grande maioria das empresas de tecnologia da região está instalada fora dos limites dos parques administrados pelo Parqtec, beneficiando-se da boa estrutura da cidade e boa qualidade dos recursos de atendimento à população, como boa rede de ensino público, boa rede rodoviária e boa infra-estrutura para o lazer.

Segundo o Prof. Sylvio Rosa Jr., São Carlos tem hoje um projeto que visa proporcionar um alto padrão de vida a todos os seus cidadãos até o ano de 2022, atingindo IDH de 0,922 até 7 de setembro daquele ano. Para isso, pretende colaborar com a atração, criação e fixação de 1011 empresas de base tecnológica na cidade, transformando São Carlos 
em uma technoville onde todos os cidadãos usufruam dos benefícios da sociedade do conhecimento.

\subsubsection{Quais as características econômicas que propiciaram o surgimento do cluster na região de São Carlos?}

O pólo tecnológico de São Carlos se beneficia da boa estrutura social da cidade, tida como uma das melhores para se viver no Estado de São Paulo. Segundo o Prof. Sylvio Rosa Jr., São Carlos tem como diferencial o bom nível de instrução de sua população, fruto de uma estrutura pública de ensino básico de ótima qualidade. Isso favoreceu a região para a instalação de um parque tecnológico, oferecendo mão-de-obra de ótima qualidade e nível técnico. $\mathrm{O}$ alto nível de escolaridade da região está diretamente ligado à boa renda per capita do município (IBGE, 2008), que diferentemente de muitos outros pólos industriais do estado, possui menor desvio padrão, ou seja, denota maior equidade na distribuição de renda do município.

\subsubsection{Como se deram as relações entre governos, instituições de ensino, institutos de pesquisa e empreendedores na concepção e implantação do cluster?}

A partir do empenho dos profissionais de instituições de ensino para composição do Parque Tecnológico de São Carlos, principalmente de pesquisadores do Instituto de Física e da Escola de Engenharia da USP, parcerias foram estabelecidas com o governo em suas três principais instâncias, municipal, estadual e federal. É de amplo interesse do poder público que a região desponte como um centro de excelência tecnológica, e há talentos disponíveis para cumprir esse intento. Entretanto, ainda é pequena a participação do setor privado no compromisso de tornar São Carlos um pólo tecnológico digno de competir com o mercado internacional. De fato, ainda são poucas as empresas de tecnologia da informação instaladas na região. Isso se dá pela constatação de que a cultura regional está mais voltada para a área acadêmica do que para o empreendedorismo, apesar do empenho coletivo em desenvolvimento de novas tecnologias e de suas patentes resultantes. O pesquisador de São Carlos ainda não se inseriu no contexto que o Parqtec trabalha, voltado para o desenvolvimento de empresas inovadoras para contribuir com o desenvolvimento econômico 
e social da região. Significa dizer que apesar do empenho de governos e instituições de ensino e pesquisa, ainda é incipiente a ação privada no município.

Um dos exemplos mais notórios de iniciativa privada é a constituição do Eco Park, empreendimento do grupo Encalso-Damha para geração de um parque de alta tecnologia na região que abrigará a primeira indústria de semicondutores da América do Sul, através de um convênio estabelecido com a empresa americana Symetrix (ANTUNES, 2008). A tecnologia que propiciou o interesse dos dois grupos de investimento foi desenvolvida nos laboratórios da Universidade Federal de São Carlos, em parceria com pesquisadores da USP, e pretende gerar um novo paradigma em memórias de sistemas digitais de informação. Apesar da prospecção tecnológica que viabilizou o desenvolvimento dos primeiros protótipos ter sido inteiramente realizada na região de São Carlos, sob fomento de fundações governamentais de financiamento à pesquisa científica, o consórcio entre Encalso e Symetrix não estabeleceu acordos com o poder público municipal nem é derivado de oportunidades oferecidas pelo município. A escolha para implantação da indústria na região se pautou pela proximidade dos centros de pesquisa que viabilizaram o surgimento da nova tecnologia e a disposição do grupo Encalso-Damha em fundar um parque tecnológico privado, que tem como exemplo o Techno Park da região de Campinas.

Recentemente, outro empreendimento estabelecido da parceria com o Governo Federal e a Associação Brasileira de Indústria de Máquinas e Equipamentos tem chamado a atenção das empresas que cogitam a possibilidade de se instalar na região. Trata-se do projeto Cidade da Energia, que inclui a construção de uma universidade para o desenvolvimento de novas tecnologias e um centro e desenvolvimento tecnológico e difusão da utilização de energia renovável.

\subsubsection{Qual a relação entre o estabelecimento do cluster e o volume de mão de obra especializada disponível na região de São Carlos?}

O cluster está diretamente apoiado sobre a disponibilidade de mão-de-obra especializada, além da questão do volume de empreendedores da região. Infelizmente, ao passo que o volume de mão-de-obra especializada continua a crescer dia após dia, formados pelas instituições de excelência em ensino tecnológico da região, o número de empreendedores oriundos dessa mesma base avança ainda a passos lentos, o que segundo o Prof. Sylvio Rosa pode ser explicado pela ausência de elementos ligados ao 
empreendedorismo na cultura profissional local. A maioria dos pesquisadores alocados em São Carlos possui recursos de fontes governamentais de fomento à pesquisa científica, e apesar dos ótimos resultados aferidos, não possuem a pretensão de serem proprietários de empresas, mas em última instância professores universitários.

Essa característica é oposta ao que é observado nos clusters de Bangalore e no Vale do Silício, mas está em perfeita coerência com aquilo que é observável no cluster de Campinas. Entretanto, tendo em vista que o empreendedorismo acadêmico foi o precursor do surgimento do Parqtec, pode-se dizer que há a possibilidade de um segundo movimento de empreendimentos, igual ao que fomentou na década de 1980 o surgimento do pólo tecnológico em São Carlos, no intuito de trazer maior visibilidade à região e, assim, atrair um número maior de indústrias dos setores associados à tecnologia de ponta, em especial à TI. Hoje, São Carlos oferece muito mais profissionais ao mercado de alta tecnologia do que tem capacidade de absorver, significando o deslocamento de boa parte dos profissionais formados na região para outras regiões do país, e em alguns casos, do mundo.

\subsubsection{Quais os tipos de relações estabelecidas entre as empresas do pólo de tecnologia de} São Carlos e como elas se dão? Existe predominância de algum dos tipos sobre os outros?

Infelizmente, as empresas de tecnologia da região de São Carlos ainda não possuem relações expressivas entre si. A maioria das relações tem como elemento central as universidades, o Parqtec e suas facilidades internas. Entre essas facilidades se encontra o Instituto Parqtec de Design, uma parceria entre a instituição e o Sebrae que sucedeu ao Centro de Modernização Empresarial de São Carlos. O Instituto de Design conta com uma planta de prototipagem, além de dispor de profissionais e recursos tecnológicos para desenvolvimento de apresentações de produtos, design de embalagens, interfaces e design gráfico para as empresas do pólo tecnológico de São Carlos. É uma das iniciativas mais inovadoras no âmbito de incubadoras e parques tecnológicos do sistema paulista, e serve como ponto de intersecção das relações estabelecidas entre os agentes de inovação do cluster.

Uma vez que a grande maioria das relações se dá entre as empresas e as instituições de ensino e pesquisa, ou entre as empresas e o Parqtec, é possível afirmar que essas instituições possuem importância acentuada na dinâmica de inovação do cluster, centralizando o fluxo de informações sob o estabelecimento de um modelo mononucleado. 


\subsubsection{Há relação de hierarquia, evidenciando um grau de importância de uma empresa} frente às outras, nos processos produtivos ou nas diversas relações estabelecidas entre as empresas do pólo tecnológico de São Carlos?

Entre as empresas ainda não há uma relação evidente de hierarquia, mas é possível perceber a preponderância da entidade administrativa do parque tecnológico, o Parqtec, além das duas universidades públicas da região, sem as quais o nascente Sistema Regional de Inovação pode colapsar.

$\mathrm{Na}$ verdade, a hierarquia das relações entre empresas não é percebida porque são poucas as iniciativas de parceria entre empresas na região. Segundo o Prof. Sylvio Rosa Jr., ainda é muito pequeno o número de relações estabelecidas entre empresas, e geralmente as parcerias se dão no escopo do Instituto de Design e as empresas que ocupam a rede de incubadoras do Parqtec. Tendo em vista que o Science Park é um empreendimento ainda muito recente, inaugurado em 2008, ainda não há empresas instaladas em plena atividade, o que significa dizer que as relações entre agentes de inovação do Parque Tecnológico ainda não foram estabelecidas.

As relações entre as empresas de TI da região, aquelas que não estão no escopo adminstrativo do Parqtec mas que mesmo assim estão incluídas no conceito de cluster de São Carlos, também são poucas, geralmente orientadas em função das conexões com a Universidade de São Paulo ou a UFSCar. Mais uma vez, é visível a configuração mononucleada, uma vez que poucas são as relações estabelecidas em diversos níveis pelas empresas e instituições ligadas ao pólo tecnológico, sendo a maioria das relações orientadas ao eixo formado pelas universidades e Parqtec.

\subsubsection{Qual a participação inicial do cluster de São Carlos nos volumes de negócios de seus} setores?

No que tange ao setor de TI, a participação da produção da região ainda é incipiente, contando com apenas um empreendimento de relevância, a empresa Opto Eletrônica, voltada para a tecnologia de comunicação ótica. Muitas outras empresas ocupam o espaço do cluster, na área de software, design, prospecção tecnológica e serviços associados à indústria de TI. Entretanto, empresas como Volkswagen, a Electrolux, Faber Castell e TAM se encontram no 
município, o que evidencia sua relevância em outros setores que se utilizam da tecnologia de informação, mas que foge ao escopo dessa pesquisa.

\subsubsection{Como se estabeleceu a rede de relações entre os agentes do pólo de tecnologia de São}

\section{Carlos (empresas e pessoas) após o início de suas atividades?}

A rede de relações entre os agentes do pólo tecnológico de São Carlos se constitui em torno dos agentes de maior predominância para o arranjo produtivo, sendo estes as duas universidades, o Parqtec e o poder público, em qualquer de suas instâncias. As empresas estabelecem raras relações de parcerias entre si, o que evidencia a carência de uma cultura organizacional local voltada para a cooperação entre os agentes de inovação. A cooperação ocorre em via dupla apenas das instituições de ensino e pesquisa para as empresas instaladas, aumentando a importância que as primeiras têm para a manutenção do modelo.

\subsubsection{Como se dá o fluxo de transferência de conhecimento entre as empresas do cluster de} São Carlos, das empresas do cluster com agentes de outros Sistemas Regionais de Inovação e mesmo com agentes de outros Sistemas Nacionais de Inovação?

Segundo o Prof. Sylvio Rosa Jr., não há um fluxo significativo de profissionais transitando entre uma empresa e outra da região, o que significa dizer que a transferência de conhecimento tácito por esse meio, típico das regiões do Vale do Silício e Bangalore, ainda não pode ser considerada como expressiva. Entretanto, as ligações entre os profissionais que trabalham nas empresas de base tecnológicas da região existem por conta de suas conexões com as instituições de ensino e pesquisa. Muitos empreendedores se conhecem desde as salas de aula das universidades, mas ainda assim não há a constituição de relações de parceria formais entre suas empresas. Aparentemente, a cultura organizacional da região não está alinhada à tendência dos clusters internacionais de estabelecer fluxos informais de informação através das conexões exógenas ao âmbito produtivo.

De fato, segundo o Prof. Sylvio Rosa Jr., não é perceptível na região um senso de comunidade que permita a mudança de atitude dos empreendedores no sentido de proporcionar a melhoria dos fluxos de informação, para que seja possível aos agentes visualizar com mais clareza as oportunidades de estabelecimento de parcerias que extravasem 
o mero compartilhamento de facilidades e custos relativos à instalação física de seus empreendimentos. Esse estágio talvez possa ser atingido a partir da instalação de novas empresas, o que deverá ocorrer nos próximos dois anos com a consolidação do Science Park e a inauguração da fábrica de semicondutores do consórcio Encalso-Symetrix, que deverá atrair para a região outros empreendimentos voltados ao atendimento das necessidades da emergente indústria de TI local.

\subsubsection{Entre os sub-setores da Tecnologia da Informação (software, serviços,} semicondutores, etc.), quais aqueles que obtiveram destaque entre os empreendimentos estabelecidos no cluster de São Carlos, tanto por seu volume de negócios como por sua excelência em inovações para o mercado?

Ainda não há acentuada relevância de mercado protagonizada pelos negócios de TI implantados em São Carlos, seja em nível nacional ou internacional. Talvez o mais expressivo dos empreendimentos seja a Opto, empresa dedicada ao desenvolvimento, fabricação e comercialização de produtos e serviços de tecnologia de ponta em Opto-Eletrônica. A empresa foi fundada há mais de vinte anos e está hoje entre as cem empresas de tecnologia que mais crescem no Brasil.

\subsubsection{Qual a importância do poder público e da legislação vigente para a manutenção do pólo tecnológico de São Carlos?}

Segundo o vice-prefeito e secretário de ciência e tecnologia, Emerson Leal, o poder público municipal é responsável por canalizar recursos que permitam que instituições como o Parqtec possam atingir a excelência produtiva em Ciência e Tecnologia necessária para alavancar a expressão da região entre os pólos tecnológicos do estado. De fato, é notória a participação das últimas três gestões municipais, formadas por ex-reitores e docentes da Universidade federal de São Carlos, na consolidação do pólo tecnológico de São Carlos através da promoção de incentivos que atraiam empresas de base tecnológica para a região e investimento em infra-estrutura que garanta a operacionalidade de negócios inovadores. 
O bom relacionamento do poder público municipal com o Governo Federal permitiu a expansão dos investimentos em infra-estrutura, e está em vias de consolidar o projeto Cidade da Energia, trazendo para a região mais um centro de excelência em pesquisas, que contará com investimentos vultosos para desenvolvimento de fontes alternativas de energia.

Segundo o Prof. Sylvio Rosa Jr., é possível verificar o comprometimento de todas as partes do poder público com o ideal de tornar São Carlos uma cidade voltada para o desenvolvimento tecnológico em nível nacional, e isso é fruto da existência de instituições de excelência em ensino e pesquisa como a UFSCar e a USP. Mais uma vez, percebe-se a importância das duas universidades na consolidação do modelo de desenvolvimento tecnológico regional adotado em São Carlos, o que remete às origens dos outros três pólos tecnológicos analisados. No caso de São Carlos, ainda não se pode dizer com exatidão quais serão os desdobramentos, principalmente no que tange às relações entre agentes de inovação, dos processos iniciados para o desenvolvimento econômico e tecnológico do cluster.

\subsubsection{Qual a posição sócio-econômica da região onde o pólo tecnológico de São Carlos está estabelecido frente ao padrão nacional e aos padrões das regiões dos demais pólos tecnológicos do mesmo setor (limitando-se aos estudados)?}

Dentre os clusters analisados, São Carlos é aquele em que a relevância econômica é menos acentuada. Nem por isso pode-se dizer que haja problemas sérios de distribuição de renda, sendo notória pelo pesquisador a boa situação social de que a cidade usufrui. Talvez em menor intensidade apenas do que no Vale do Silício, entre as regiões estudadas São Carlos conta com ótimo nível de equidade social, garantida pelas gestões políticas voltadas para o atendimento das necessidades básicas da população de baixa renda e para o desenvolvimento industrial e comercial, no intuito de aumentar o número de vagas de empregos. A boa condição econômica da cidade de São Carlos contribui para o surgimento de novas iniciativas de negócios na região. 


\subsubsection{Há relação entre os fatores de desenvolvimento social da região de São Carlos com} o pólo tecnológico?

O pólo tecnológico de São Carlos depende das boas condições para adaptação dos recursos humanos e empreendedores na região. A maior parte dos pesquisadores e estudantes ligados às universidades da região veio de fora, o que significa dizer que a grande massa de talentos de São Carlos não é nativa, e obedece a uma lógica de retorno aos seus locais de origem assim que suas atividades acadêmicas se encerram. Muitos desses profissionais permanecem na região por encontrar condições sócio-econômicas privilegiadas, frutos da boa articulação dos fatores de desenvolvimento social suportados pelo poder público e iniciativas privadas. No atual estágio de desenvolvimento do cluster, é possível dizer que as condições sócio-econômicas impactam muito mais na expansão do pólo tecnológico do que o inverso, uma vez que a produção econômica derivada das atividades produtivas em tecnologia ainda não atingiu o volume necessário para ampliar o desenvolvimento econômico-social da região ou melhorar a distribuição de renda.

Pode-se dizer também que a maior parte da receita gerada na região, que se desdobra em impostos e iniciativas que contribuem para as melhorias sociais em São Carlos, é fruto da presença das instituições de ensino e pesquisa, o que aumenta o volume de negócios realizados no comércio e gera uma população flutuante que está diretamente ligada a diversos investimentos externos perpetrados na região.

\subsubsection{Como o pólo tecnológico de São Carlos se integra com o desenvolvimento de} pesquisa científica da região que ocupa? Qual sua participação no estabelecimento de implementos educacionais da região?

O pólo tecnológico de São Carlos é fruto da presença de duas instituições de ensino e pesquisa de expressão internacional, e por isso está diretamente ligado ao desenvolvimento da pesquisa científica da região. Iniciativas como a do Parqtec têm a função de viabilizar a exploração econômica das tecnologias desenvolvidas no âmbito acadêmico, através do oferecimento de condições diversas para inserção de novos empreendimentos no mercado, voltados à viabilização comercial das inovações geradas nas instituições de ensino e pesquisa.

A participação do pólo tecnológico no estabelecimento de implementos educacionais se apóia nas parcerias geradas entre as empresas da região e as instituições de ensino superior, 
sob convênios que destinam recursos para expansão de laboratórios, bolsas a pesquisadores e aumento do número de vagas. Entretanto, essas iniciativas ainda são poucas, dado que o cluster ainda não atingiu a expressão necessária para contribuir em maior volume com os investimentos em educação da cidade. 


\section{ANÁLISE COMPARATIVA ENTRE CLUSTERS (CROSS-CASE)}

Após a verificação dos resultados gerados pela aplicação dos instrumentos de trabalho (Apêndices A e B) nos dois estágios anteriores da pesquisa, é possível a análise comparativa cross-case de cunho qualitativo.

\subsection{Questões de 1 a 5.}

O Quadro 3 permite uma análise mais objetiva dos primeiros resultados aferidos:

Quadro 3

\begin{tabular}{|c|c|c|c|c|}
\hline Questões & Vale do Silício & Bangalore & Campinas & São Carlos \\
\hline $\begin{array}{l}\text { 1. Como se deu o processo } \\
\text { histórico de } \\
\text { desenvolvimento do pólo } \\
\text { tecnológico? }\end{array}$ & $\begin{array}{l}\text { Investimentos } \\
\text { governamentais. } \\
\text { Empreendedorismo. } \\
\text { Suporte instituições de } \\
\text { ensino. } \\
\end{array}$ & \begin{tabular}{|l} 
Investimentos \\
internacionais e \\
governamentais. \\
Empreendedorismo \\
argonauta \\
\end{tabular} & $\begin{array}{l}\text { Investimentos } \\
\text { Governamentais. } \\
\text { Suporte instituições de } \\
\text { ensino. }\end{array}$ & $\begin{array}{l}\text { Canalização de } \\
\text { investimentos públicos } \\
\text { por Fundação. } \\
\text { Empreendedorismo } \\
\text { acadêmico. }\end{array}$ \\
\hline $\begin{array}{l}\text { 2. Quais as características } \\
\text { econômicas que } \\
\text { propiciaram seu surgimento } \\
\text { na região? }\end{array}$ & $\begin{array}{l}\text { Recursos econômicos } \\
\text { abundantes. } \\
\text { Investimentos } \\
\text { Governamentais. } \\
\text { Cultura do } \\
\text { Empreendedorismo. }\end{array}$ & $\begin{array}{l}\text { Retorno dos } \\
\text { empreendedores. } \\
\text { Investimentos } \\
\text { governamentais. }\end{array}$ & $\begin{array}{l}\text { Boa infra-estrutura. } \\
\text { Economia industrial } \\
\text { consolidada. } \\
\text { Investimentos } \\
\text { governamentais }\end{array}$ & $\begin{array}{l}\text { Boa infra-estrutura. Boa } \\
\text { equidade social. } \\
\text { Investimentos } \\
\text { governamentais. }\end{array}$ \\
\hline $\begin{array}{l}\text { 3. Como se deram as } \\
\text { relações entre governos, } \\
\text { instituições de ensino, } \\
\text { institutos de pesquisa e } \\
\text { empreendedores na } \\
\text { concepção e implantação do } \\
\text { cluster? }\end{array}$ & $\begin{array}{l}\text { Empreendedores } \\
\text { conectados à } \\
\text { universidade iniciam o } \\
\text { processo de } \\
\text { implantação sob } \\
\text { auspício } \\
\text { governamental. }\end{array}$ & $\begin{array}{l}\text { Empreendedores } \\
\text { conectados a outros } \\
\text { clusters influenciam } \\
\text { ações do governo com } \\
\text { apoio da universidade } \\
\text { para implantação. }\end{array}$ & $\begin{array}{l}\text { Universidade em acordo } \\
\text { com o governo realiza a } \\
\text { implantação e gera } \\
\text { estratégia para atrair } \\
\text { empreendedores. }\end{array}$ & $\begin{array}{l}\text { Universidades e governo } \\
\text { estabelecem acordo de } \\
\text { implantação, atraindo } \\
\text { empreendedores. }\end{array}$ \\
\hline $\begin{array}{l}\text { 4. Qual a relação entre o } \\
\text { estabelecimento do cluster e } \\
\text { o volume de mão-de-obra } \\
\text { especializada disponível na } \\
\text { região? }\end{array}$ & $\begin{array}{l}\text { Alta relação. Mão-de- } \\
\text { obra gera maior número } \\
\text { de empreendedores. }\end{array}$ & $\begin{array}{l}\text { Alta relação. } \\
\text { Abundância de mão-de- } \\
\text { obra mantém custos } \\
\text { salariais e gera } \\
\text { competitividade. } \\
\end{array}$ & $\begin{array}{l}\text { Média relação. Cluster } \\
\text { não absorve grande } \\
\text { parte da mão-de-obra } \\
\text { gerada. }\end{array}$ & $\begin{array}{l}\text { Pequena relação. Apenas } \\
\text { uma pequena parte da } \\
\text { mão-de-obra formada na } \\
\text { região é aproveitada no } \\
\text { cluster. }\end{array}$ \\
\hline $\begin{array}{l}\text { 5. Quais os tipos de } \\
\text { relações estabelecidas entre } \\
\text { as empresas do pólo de } \\
\text { tecnologia e como elas se } \\
\text { dão? Existe predominância } \\
\text { de algum dos tipos sobre os } \\
\text { outros? }\end{array}$ & $\begin{array}{l}\text { Múltiplas relações } \\
\text { internas complexas em } \\
\text { diversos níveis. Não há } \\
\text { predominância de uma } \\
\text { relação ou agente sobre } \\
\text { outro. }\end{array}$ & $\begin{array}{l}\text { Relações voltadas para } \\
\text { o exterior. Bom nível de } \\
\text { relações internas, } \\
\text { baseadas em } \\
\text { desenvolvimento } \\
\text { tecnológico cooperado } \\
\text { e divisão dos custos de } \\
\text { ocupação espacial. }\end{array}$ & $\begin{array}{l}\text { Relações voltadas para } \\
\text { a universidade e os } \\
\text { institutos de pesquisa. } \\
\text { Não há muitas relações } \\
\text { produtivas entre } \\
\text { empresas. Elevada } \\
\text { importância das relações } \\
\text { com instituições de } \\
\text { ensino e pesquisa. }\end{array}$ & $\begin{array}{l}\text { Relações voltadas para a } \\
\text { universidade e os } \\
\text { institutos de pesquisa. } \\
\text { Não há muitas relações } \\
\text { produtivas entre } \\
\text { empresas. Elevada } \\
\text { importância das relações } \\
\text { com instituições de } \\
\text { ensino e pesquisa. }\end{array}$ \\
\hline
\end{tabular}

\section{Quadro de Análise Questões de 1 a 5}

Fonte: Autor

A análise cruzada das questões que culminaram na consolidação das relações entre agentes dos clusters abordados demonstra algumas das principais características observáveis 
até os dias de hoje em cada um dos modelos estabelecidos. Suas diferenças e similitudes são elencadas, tópico a tópico a seguir.

Sobre o processo histórico de formação dos pólos tecnológicos, todos os clusters abordados possuem a presença de investimentos públicos para a sua formação. Em todos os casos, exceto de São Carlos, o governo é fornecedor de linhas de financiamento, investe na implantação de centros de pesquisa e expansão das universidades, além de ser também cliente direto de muitas das empresas instaladas nos clusters. No Vale do Silício e em Bangalore, grande parte dos investimentos em defesa dos governos é canalizado para as empresas desenvolvedoras de novas tecnologias dos clusters. Já em Campinas, o governo tem negócios com algumas empresas ligadas à Fundação $\mathrm{CPqD}$, além de investir nas pesquisas desenvolvidas pelos centros de inovação da região. Nos três clusters, a presença do governo como alicerce gerador de receitas que viabilizaram o desenvolvimento da indústria de alta tecnologia na região foi essencial, e pode ser considerada como uma tendência para a eclosão de pólos tecnológicos.

Em São Carlos não há um volume relevante de contratos fechados entre as empresas e o governo, mas ainda assim, a presença do poder público foi marcante para sua constituição. Foi através de verbas do CNPq e de consórcios estabelecidos com a Prefeitura Municipal que se viabilizou a instalação do Parqtec e, com ele, todo o cluster de empresas de alta tecnologia na região. É necessário lembrar que as duas universidades instaladas, USP e UFSCar, também pertencem ao poder público, e apesar de sua gestão autônoma, são canalizadoras de verbas públicas em políticas de desenvolvimento industrial, através do investimento em pesquisas que podem se desdobrar em inovações para o mercado.

A presença de instituições de ensino de relevância também é um fator preponderante e semelhante nos quatro clusters analisados. No caso do Vale do Silício, há a presença de Stanford e outra série de instituições de ensino que se incumbem no oferecimento de novos talentos para a expansão do cluster. Em Bangalore, a Universidade de Bangalore e os diversos centros de formação técnica da região são responsáveis pelo fornecimento de recursos humanos de altíssima qualidade para a manutenção das atividades no cluster. No Brasil não é diferente. Em todos os casos abordados a presença de centros de ensino de excelência foi marcante para a consolidação do cluster, e até mesmo pelos processos que iniciaram sua formação.

Uma das questões mais importantes para o surgimento dos clusters nas regiões abordadas é o empreendedorismo. Há uma relação muito distinta entre empreendedores e consolidação dos arranjos produtivos nos clusters abordados. Enquanto no Vale do Silício foi 
justamente a cultura voltada para o empreendedorismo que permitiu o surgimento do cluster, desenvolvendo um grande número de agentes que através de empenho articulado estabeleceu competências coletivas para a região sem a intermediação institucionalizada de um agente central, nos clusters brasileiros não houve empenho exacerbado dos empreendedores. $\mathrm{Na}$ verdade, o modelo observado no Brasil para surgimento dos pólos tecnológicos, como já visto anteriormente, foi o de empreendedorismo acadêmico, ou seja, uma série de iniciativas oriundas das instituições de ensino e centros de pesquisa para fomentar o surgimento de uma base de empresas de alta tecnologia nas regiões. A comparação entre os casos brasileiros e o Vale do Silício denota quão distante o Brasil ainda se encontra da disseminação dos valores de empreendedorismo. Enquanto os empreendedores do Vale do Silício geraram um cluster através da interação não mediada - talvez apenas observada - por agentes centrais, os empreendedores brasileiros tiveram que ser estimulados pelas iniciativas governamentais e das instituições de ensino e pesquisa da região. Tanto no caso de Campinas quanto no de São Carlos, não fosse a presença de unidades administrativas ligadas ao poder público e às instituições de ensino, voltadas para o desenvolvimento dos parques tecnológicos regionais, dificilmente se teria a consolidação de algo parecido com um cluster de tecnologia.

No que tange ao empreendedorismo, o cluster de Bangalore é definitivamente um caso a parte. A região contava com capital local, mas não foram os empreendedores sediados em Bangalore que iniciaram o processo de consolidação do cluster, mas sim aqueles indianos expatriados que moraram durante anos no Vale do Silício e em outros pólos tecnológicos de excelência. Por manterem relações com o país de origem, tinham informações detalhadas sobre o desenvolvimento tecnológico da região, além da característica que mais motivou o surgimento do cluster: mão-de-obra barata e de qualidade. A partir do conhecimento disso, os antigos funcionários indianos de empresas do Vale do Silício passaram a abrir seus próprios negócios para atendimento de segmentos específicos de TI ligados às cadeias produtivas globais, instalando suas unidades de produção em Bangalore para redução dos custos relativos a folha de pagamento. Esse movimento foi acompanhado por outras grandes multinacionais, fazendo com que o cluster alcançasse relevância global.

De certa forma, a cultura organizacional voltada para o empreendedorismo típica do Vale do Silício contaminou a cultura organizacional de Bangalore com o retorno dos argonautas (SAXENIAN, 2006). Bangalore se estabelece sobre uma lógica típica do capitalismo informacional, na qual o espaço físico entre cadeias produtivas perde relevância quando o principal produto gerado é a informação, passível de trafegar em milésimos de segundos pela rede internacional de computadores. O empreendedorismo que se assiste lá 
também acompanha essa lógica, sendo um simulacro adaptado daquele tipo de empreendedorismo observado nos Estados Unidos.

No Brasil, não fosse a vontade oriunda dos centros de pesquisa e ensino, seria muito difícil estabelecer clusters de alta tecnologia apenas pela iniciativa do corpo de empreendedores. De fato, apesar das iniciativas nesse sentido, as instituições acadêmicas ainda geram poucos empreendedores, e muitos especialistas em gestão e tecnologia que serviriam como suporte analítico, informacional e de inovação aos empreendedores. Ainda há muito a ser trabalhado para a mudança da cultura que cerca o aparato que propiciou o surgimento dos clusters, pois isso se desdobrará nos tipos de relações estabelecidas entre os agentes e impactará no desenvolvimento futuro dos arranjos produtivos locais.

Quanto às características econômicas que propiciaram o surgimento dos clusters em suas respectivas regiões (questão 2), é possível dizer que há uma gradação de desenvolvimento econômico inicial nessas regiões, sendo a região do Vale do Silício altamente rica, detentora da melhor infra-estrutura e possuidora de uma boa distribuição de renda, que gera um padrão mínimo de vida e consumo que está bem acima daquilo que é observado nos outros casos estudados. Entre as regiões mais e menos desenvolvidas economicamente estão os clusters nacionais estudados. De fato, tanto a região de Campinas quanto a região de São Carlos possuem vantagens econômicas frente ao restante do Brasil, que estão ancoradas na historicidade de seu desenvolvimento industrial, e remontam do capital originado com as primeiras culturas agrícolas (cana e café) exportáveis da economia brasileira. A presença de uma infra-estrutura derivada do sucesso econômico coloca as regiões em foco para a instalação de plantas industriais, beneficiadas pela possibilidade de menores custos logísticos de distribuição de produtos e acesso a recursos humanos.

O cluster de Bangalore é o menos desprovido de vantagens econômicas entre os analisados. Apesar do histórico de surgimento ligado ao grande volume de investimentos estatais em infra-estrutura e centros de pesquisa e ensino, a região não possui uma cultura industrial consolidada desde sua implantação, mas somente sofreu de adendos culturais desenvolvimentistas a partir do retorno dos primeiros engenheiros e cientistas expatriados. $\mathrm{O}$ poder público foi o agente central de desenvolvimento econômico até a instalação das primeiras empresas do cluster. A presença de duas gigantes nacionais como a Wipro e a Infosys deu início a uma série de iniciativas privadas para reduzir as disparidades sociais da região, típicas de qualquer região da Índia, um país de cultura ainda muito fortemente voltada para a segregação social. Bangalore conseguiu suplantar as desvantagens econômico-sociais 
enquanto cluster de tecnologia pela presença de instituições de ensino e pesquisa de excelência, em especial as estatais.

No âmbito das relações entre governos, instituições de ensino, instituições de pesquisa e empreendedores na concepção e implantação dos clusters abordados, mais uma vez há diferenças marcantes, todas elas ligadas à diminuída participação dos empreendedores na consolidação dos clusters nacionais. Apesar da relação entre governo e instituições de ensino e pesquisa ser muito parecida em todos os casos estudados, talvez um pouco menos evidente no Vale do Silício onde há maior autonomia das universidades frente ao poder público, nos casos brasileiros as relações estabelecidas entre as instituições centrais e os empreendedores não foram marcantes para a concepção do cluster, mas são extremamente importantes para a permanência dos empreendimentos na região. Nos clusters internacionais há um equilíbrio dessa importância, sendo os empreendedores igualmente vitais na formação do cluster.

No caso de Campinas, por exemplo, com exceção das multinacionais instaladas, poucas empresas que iniciaram suas atividades no cluster no início de sua formação permanecem até hoje, principalmente aquelas que iniciaram como start ups. Aliás, o cluster não se formou em torno de uma necessidade de mercado, pelas mãos de empreendedores, mas em torno dos ideais que nortearam a idealização do projeto do pólo tecnológico no âmbito da universidade. Em São Carlos a realidade é muito parecida, sendo o ímpeto que derivou na consolidação do cluster oriundo da percepção de oportunidade e verificação do talento natural da região pelos professores das universidades instaladas. As duas regiões, e talvez muito mais São Carlos, por ainda possuir uma estrutura produtiva em tecnologia pouco expressiva frente aos demais clusters estudados, tiveram o surgimento de seus arranjos produtivos baseado em um tipo de empreendedorismo que não era oriundo do mercado, mas de uma ideologia cunhada em preceitos difundidos nos corredores das universidades como instruções para o desenvolvimento das regiões onde estas estão instaladas.

As relações entre empreendedores também são pontos muito importantes para diferenciação dos modelos estabelecidos nos clusters abordados. No caso do Vale do Silício, é notória a estrutura gerada entre as empresas em torno de projetos de inovação, gerando cadeias produtivas, ou seja, arranjos produtivos com a presença de relações de fornecimento e consumo entre os agentes inseridos no cluster. Significa dizer que os produtos finais possuem partes desenvolvidas por mais de um agente do cluster, através de diversos tipos de relações. As empresas já nascem próximas umas das outras, por conta das relações informais estabelecidas entre empreendedores e profissionais de tecnologia, oriundas do extenso convívio em universidades e centros de pesquisa e desenvolvimento. As relações entre 
empreendedores no Vale do Silício denotam a existência de um sentimento de pertencimento a uma comunidade, ancorado a uma cultura típica da região, voltada para o empreendimento e processo contínuo de inovação.

Os empreendedores de Bangalore, conforme mencionado diversas vezes ao longo do trabalho, também estão conectados por elementos da cultura típica do vale do Silício, após anos trabalhando no exterior em companhias de tecnologia. Entretanto, as relações que seus empreendimentos estabelecem entre si no âmbito do cluster têm a mesma intensidade daquelas estabelecidas com outros agentes de inovação no exterior (SAXENIAN, 2006). Assim como visto, a cultura organizacional de Bangalore é muito mais voltada para fora da Índia do que para dentro, o que significa dizer que a noção de pertencimento ao cluster perde o sentido quando as vantagens competitivas cessam. Há compromisso com as reformas sociais e políticas por parte dos empreendedores, pois essas fazem parte da ideologia cunhada nos anos a fio de pesquisa e desenvolvimento nas empresas americanas e européias, mas isso não significa realizar uma relação comercial interna a peso de fortalecer o cluster em detrimento de aproveitamento de custos mais competitivos em relações com outras partes do mundo. A empresa sitiada em Bangalore é, antes de indiana, uma empresa voltada para o mercado externo, portanto, uma empresa do mundo.

As empresas dos clusters nacionais analisados raramente estabelecem relações entre si, e na maioria das vezes o fazem nas reuniões promovidas pelas unidades gestoras dos pólos tecnológicos, apenas para discutir os termos de utilização e provimento dos recursos ligados à ocupação física e seu compartilhamento entre agentes.

Quanto ao surgimento do cluster em função da mão-de-obra disponível nas regiões abordadas (questão 4), todos os casos estudados detêm excelência na formação de profissionais altamente capacitados em tecnologia de ponta. Entretanto, há diferenças relacionadas às causas e consequiências da existência de mão-de-obra. No Vale do Silício, foi a própria mão-de-obra disponível (estudantes e pesquisadores ligados às instituições de ensino locais) que iniciaram o processo de consolidação do cluster, tornando-se empreendedores. Portanto, o cluster se formou em conseqüência da mão-de-obra disponível, mas, em pouco tempo, teve que importar mão-de-obra especializada de outros lugares do mundo (inclusive, e principalmente, da Índia) por conta da expansão do volume de empresas instaladas. Já em Bangalore, o cluster se formou exatamente pela percepção de que a existência de mão-de-obra especializada em abundância consegue manter por algum tempo os níveis salariais a patamares competitivos, principalmente nas áreas de desenvolvimento e pesquisa, o que torna convidativo aos empreendedores iniciar negócios na região. 
Já nos clusters nacionais, a existência de mão-de-obra disponível teve pouca relevância na formação dos clusters. A importância das universidades para as empresas do cluster se baseia muito mais no oferecimento de uma estrutura de pesquisa compartilhada e de empreendedores de alto nível técnico do que no fornecimento de mão-de-obra especializada. Não significa dizer que não haja a formação de excelentes profissionais nas universidades dos casos brasileiros, mas apenas que o pólo tecnológico não se formou em função disso. Essa percepção é corroborada pelo fato de que apenas uma pequena parte da mão-de-obra formada na região é absorvida pelo cluster. A maior parte dos estudantes formados em Campinas e São Carlos migra para suas regiões de origem, por não haver empregos para todos. Isso é menos percebido em Campinas, por haver outros setores da indústria que ajudam na absorção de profissionais que originalmente trabalhariam com Tecnologia da Informação. Até mesmo os empreendedores formados nessas regiões, após o período de incubação de suas empresas, encontram dificuldades em continuar no local, migrando para regiões que ofereçam melhores condições de aferir competitividade ou, infelizmente, encerrando as atividades.

Sobre as relações estabelecidas entre as empresas dos pólos de tecnologia abordados (questão 5), e da existência de predominância de um tipo sobre os outros, pode-se dizer que mais uma vez, os clusters nacionais possuem grandes diferenças em relação aos clusters internacionais. No Vale de Santa Clara, como já visto, as relações estabelecidas ocorrem em múltiplos níveis, transformando-se em diversas cadeias produtivas em que os agentes desempenham diferentes papéis. A complexidade gerada pelo número de relações estabelecidas entre as empresas deriva em redução da dependência que cada uma delas em função de outros agentes específicos. Isso faz com que haja maior equidade de importância entre os agentes inseridos no contexto produtivo. Empresas que competem no oferecimento de um determinado produto ou serviço podem ser parceiras no desenvolvimento de outro, fato não raro na bibliografia analisada. Dessa forma, sinergia e competição andam lado a lado, demonstrando que o conceito original de cluster é perfeitamente adotável para descrever as relações ocorridas no Vale do Silício.

A temática da sinergia foi levada pelos argonautas para Bangalore, mas expandidas em um conceito global. Dessa forma, as competências regionais se apóiam na eficiência pautada pela relação qualidade/custo do que é desenvolvido na região. A dinâmica das relações estabelecidas pelas empresas do cluster em nível regional corrobora com a dinâmica das relações de nível global, pois compartilham de preceitos de uma cultura voltada para a lógica do capital informacional, que é a de aferir maiores lucros através da otimização da relação valor agregado/custos. Assim, é pertinente dizer que o tipo de relação entre empresas de 
Bangalore é um upgrade do que é visto nos Estados Unidos, por ser uma combinação de elementos culturais importados de lá com as necessidades ditadas pelas regras do mercado global.

Os casos brasileiros destoam completamente dos casos internacionais no que toca às relações entre empresas dos clusters abordados. Tanto em São Carlos quanto em Campinas, ao menos pela ótica do pesquisador e dos entrevistados, é ainda incipiente o volume de relações estabelecidas entre empresas do cluster para estabelecimento de cadeias produtivas locais de alta tecnologia. De fato, o pesquisador teve contato com um caso de aquisição de uma empresa no exterior por uma empresa local para produção de um insumo que necessitava, passando da relação cliente-fornecedor para uma relação corporativa matrizsubsidiária. Ocorre que no cluster existe outra empresa que desenvolveu tecnologia similar à necessária para produção do insumo e essa sequer foi cogitada numa relação de parceria para obter resultados finais satisfatórios, pelo simples fato de uma empresa não conhecer o que a outra faz. As informações nos clusters nacionais são mais controladas do que divulgadas, tornando mais difícil o estabelecimento de relações entre os agentes.

Segundo aferido pelas entrevistas, são muitos os intentos desempenhados pelas unidades gestoras dos pólos brasileiros para aproximar os empreendedores e gestores das empresas instaladas, mas os poucos resultados obtidos estão muito aquém daqueles percebidos nos Estados Unidos e na Índia. Aparentemente, o problema repousa sobre a diferença das culturas organizacionais dos arranjos produtivos internacionais e nacionais. Enquanto na cultura típica do Vale do Silício e na cultura híbrida de Bangalore é possível verificar valores mais concentrados na obtenção de competitividade através do estabelecimento de relações sinérgicas e compartilhamento das informações em nível regional, a cultura organizacional brasileira se apóia no desenvolvimento de vantagens para lidar com a competição. Priorizando a competição, bloqueia-se a disponibilidade de informações que possam significar o surgimento de relações sinérgicas que intensifiquem a competitividade, ou seja, tornar-se hábil para a competição e flexível a ponto de continuar existindo quando o contexto de competição não mais existir.

Os empreendedores brasileiros, à luz do que ocorre nos clusters internacionais, parecem trabalhar sob um esforço de guerra de contra-inteligência contínuo. Talvez se as empresas nacionais de tecnologia de informação localizadas nos clusters abordados estabelecessem maiores relações formais (controláveis) e informais (incontroláveis), seria possível aumentar o ritmo de surgimento de inovações, como ocorre no Vale do Silício e tantos outros clusters da Ásia, não somente em Bangalore. A cultura organizacional da 
Califórnia, que privilegia a atuação de um mesmo profissional em diversas empresas ao longo de sua vida produtiva, privilegia o fluxo de conhecimento tácito entre organizações, auxiliando no processo de agregação de novos conhecimentos, o que costuma derivar em um número maior de inovações. Já no Brasil, a cultura organizacional ainda está ligada à permanência por vários anos em uma única companhia, aquilo que se chama localmente de "fazer carreira" em uma única empresa. Quase todos os profissionais das multinacionais e empresas locais instaladas nos clusters nacionais têm como meta se aposentar em suas empresas, aferindo novas posições que lhes garanta melhorias salariais. Nos clusters internacionais, o mote da maioria é trabalhar na empresa o tempo necessário para obter experiência e recursos suficientes para abrir o próprio negócio. A isso, dá-se o nome na literatura de cultura organizacional voltada para o empreendedorismo (SAXENIAN, 1994). 


\subsection{Questões de 6 a 10}

A partir do Quadro 4 abaixo, é possível continuar a análise cross-case iniciada.

\section{Quadro 4}

\begin{tabular}{|c|c|c|c|c|}
\hline Questões & Vale do Silício & Bangalore & Campinas & São Carlos \\
\hline $\begin{array}{l}\text { 6. Há relação de hierarquia, } \\
\text { evidenciando um grau de } \\
\text { importância de uma } \\
\text { empresa frente às outras, } \\
\text { nos processos produtivos ou } \\
\text { nas diversas relações } \\
\text { estabelecidas entre as } \\
\text { empresas do cluster? }\end{array}$ & $\begin{array}{l}\text { Não há importância } \\
\text { exacerbada de um } \\
\text { agente frente a outro } \\
\text { nas relações } \\
\text { estabelecidas, sejam } \\
\text { entre empresas ou com } \\
\text { instituições de ensino e } \\
\text { pesquisa. }\end{array}$ & $\begin{array}{l}\text { Equidade nas relações } \\
\text { entre empresas. O } \\
\text { Governo tem } \\
\text { importância acentuada } \\
\text { entre os agentes do } \\
\text { setor, mas isso não } \\
\text { compromete a } \\
\text { estabilidade do modelo. }\end{array}$ & $\begin{array}{l}\text { Raras relações entre } \\
\text { empresas, não as } \\
\text { tornam relevantes frente } \\
\text { a outras. Entretanto, a } \\
\text { importância das } \\
\text { instituições de ensino e } \\
\text { pesquisa em relação } \\
\text { frente às empresas é } \\
\text { acentuada. }\end{array}$ & $\begin{array}{l}\text { Raras relações entre } \\
\text { empresas, não as tornam } \\
\text { relevantes frente a outras. } \\
\text { Entretanto, a importância } \\
\text { das instituições de ensino } \\
\text { e pesquisa em relação } \\
\text { frente às empresas é } \\
\text { acentuada. }\end{array}$ \\
\hline $\begin{array}{l}\text { 7. Qual a participação inicial } \\
\text { dos pólos tecnológicos nos } \\
\text { volumes de negócios de } \\
\text { seus setores? }\end{array}$ & Alta, em nível global. & Alta, em nível global. & $\begin{array}{l}\text { Alta no escopo nacional } \\
\text { (institutos de pesquisa e } \\
\text { desenvolvimento). Baixa } \\
\text { participação das } \\
\text { empresas em nível } \\
\text { global. }\end{array}$ & $\begin{array}{l}\text { Média em nível nacional. } \\
\text { Baixíssima em nível } \\
\text { global. }\end{array}$ \\
\hline $\begin{array}{l}\text { 8. Como se estabeleceu a } \\
\text { rede de relações entre os } \\
\text { agentes do pólo de } \\
\text { tecnologia (empresas e } \\
\text { pessoas) após o início de } \\
\text { suas atividades? }\end{array}$ & $\begin{array}{l}\text { Relações complexas } \\
\text { em múltiplos níveis } \\
\text { entre os diversos } \\
\text { agentes do cluster, } \\
\text { formais e informais. }\end{array}$ & $\begin{array}{l}\text { Relações complexas } \\
\text { em múltiplos níveis } \\
\text { entre os diversos } \\
\text { agentes do mercado } \\
\text { global, formais e } \\
\text { informais. }\end{array}$ & $\begin{array}{l}\text { Raras relações entre } \\
\text { empresas. Fortes } \\
\text { relações com as } \\
\text { instituições de ensino e } \\
\text { pesquisa. }\end{array}$ & $\begin{array}{l}\text { Raras relações entre } \\
\text { empresas. Fortes } \\
\text { relações com as } \\
\text { instituições de ensino e } \\
\text { pesquisa. }\end{array}$ \\
\hline $\begin{array}{l}\text { 9. Como se dá o fluxo de } \\
\text { transferência de } \\
\text { conhecimento entre as } \\
\text { empresas do mesmo } \\
\text { cluster, entre agentes de } \\
\text { outros Sistemas Regionais } \\
\text { de Inovação e mesmo entre } \\
\text { agentes de outros Sistemas } \\
\text { Nacionais de Inovação? }\end{array}$ & $\begin{array}{l}\text { Intenso fluxo de } \\
\text { transferência de } \\
\text { conhecimento entre } \\
\text { empresas e demais } \\
\text { agentes, através de } \\
\text { relações formais e } \\
\text { informais estabelecidas } \\
\text { no âmbito do cluster. }\end{array}$ & $\begin{array}{l}\text { Intenso fluxo de } \\
\text { transferência de } \\
\text { conhecimento entre } \\
\text { empresas e demais } \\
\text { agentes, através de } \\
\text { relações formais e } \\
\text { informais estabelecidas } \\
\text { interna e externamente. }\end{array}$ & $\begin{array}{l}\text { Fluxo de transferência } \\
\text { de conhecimento } \\
\text { ocorrido nas relações } \\
\text { com instituições de } \\
\text { ensino e pesquisa. }\end{array}$ & $\begin{array}{l}\text { Fluxo de transferência de } \\
\text { conhecimento ocorrido } \\
\text { nas relações com } \\
\text { instituições de ensino e } \\
\text { pesquisa. }\end{array}$ \\
\hline $\begin{array}{l}\text { 10. Entre os sub-setores da } \\
\text { Tecnologia da Informação } \\
\text { (software, serviços, } \\
\text { semicondutores, etc.), quais } \\
\text { aqueles que obtiveram } \\
\text { destaque entre os } \\
\text { empreendimentos } \\
\text { estabelecidos no cluster, } \\
\text { tanto por seu volume de } \\
\text { negócios como por sua } \\
\text { excelência em inovações } \\
\text { para o mercado? }\end{array}$ & $\begin{array}{l}\text { Destaque em todos os } \\
\text { sub-setores de TI, } \\
\text { especialmente em } \\
\text { semicondutores e } \\
\text { software. }\end{array}$ & Software e serviços. & $\begin{array}{l}\text { Software, } \\
\text { desenvolvimento e } \\
\text { montagem de } \\
\text { equipamentos de } \\
\text { telecomunicações. }\end{array}$ & $\begin{array}{l}\text { Software, design e } \\
\text { desenvolvimento de } \\
\text { novos materiais } \\
\text { semicondutores (ainda } \\
\text { não há indústria } \\
\text { instalada). }\end{array}$ \\
\hline
\end{tabular}

Quadro de Análise Questões de 6 a 10

Fonte: Autor 
Sobre a existência de uma relação hierárquica entre os arranjos produtivos constituídos no interior do cluster por empresas (questão 6) e relevância de importância de um dos agentes frente aos demais, em relação aos casos nacionais é impossível dimensionar uma tendência para a hierarquização das relações entre empresas, uma vez que elas são muito raras. É evidente a importância dos centros de pesquisa e instituições de ensino para o funcionamento do cluster, demonstrando um elevado grau de dependência de todo o pólo tecnológico em relação a esses agentes centrais. Sem a presença da Unicamp, por exemplo, dificilmente haveria articulação entre as empresas do cluster de Campinas, uma vez que a Universidade centraliza a maior parte das relações estabelecidas para desenvolvimento de inovação. $\mathrm{O}$ mesmo ocorre com as universidades de São Carlos, que agem como principal fonte de inovação para o cluster, além de prover o arranjo produtivo quanto ao quadro de empreendedores.

No caso do Vale do Silício, as relações hierárquicas geradas pelo estabelecimento de cadeias produtivas entre as empresas do cluster, sejam cooperadas ou não, se diversificam e acabam por não constituir uma tendência que denote a importância exacerbada de uma instituição frente às demais. Ao menos no que tange às relações entre empresas, é perceptível que qualquer empresa que entre em colapso significará a oportunidade para que outra ocupe seu lugar, e não necessariamente o colapso do arranjo produtivo. Nos casos brasileiros, qualquer empresa que entre em colapso afetará muito pouco à condição dos clusters, pois esses não se baseiam nas relações entre empresas, mas nas relações das empresas com os agentes centrais, que são as instituições de ensino e centros de pesquisa. Se estes vierem a colapsar, possivelmente todo o modelo ficará instável.

Em Bangalore as relações entre empresas não se dão apenas no âmbito do cluster, mas no âmbito global. Esse tipo de arranjo possui vantagens e desvantagens frente ao que é percebido, por exemplo, no Vale do Silício. Como vantagens, é possível perceber que quaisquer problemas encontrados em relações no âmbito interno podem ser superados através das relações estabelecidas com o ambiente externo. Entretanto, estabelecer relações produtivas com o exterior significa ficar vulnerável às intempéries dos ambientes em que as demais organizações coordenadas além das fronteiras estão instaladas. Questões políticas de uma nação onde um parceiro está instalado podem afetar diretamente os objetivos das unidades instaladas no interior do cluster. Esse problema pode ser equacionado com a diversificação das relações internacionais e nacionais, fato perceptível na dinâmica de atuação do cluster de Bangalore. 
Sobre a participação inicial dos pólos tecnológicos abordados no volume de negócios de seus setores (questão 7), a importância do Vale do Silício em todos os setores de TI em nível global é notória e notável, influenciando diversos outros arranjos produtivos a seguirem seu modelo de desenvolvimento. Bangalore se tornou um cluster de TI sob a oportunidade de barateamento dos custos operacionais observada pelos argonautas e multinacionais que se instalaram na região, conforme visto anteriormente. Desde o início das operações, Bangalore já tinha uma fatia expressiva do mercado de softwares em nível global, e com o tempo passou a desempenhar a função de principal pólo de serviços do setor de TI do mundo. Já Campinas e São Carlos iniciaram suas operações de forma muito diferente dos casos internacionais. No caso de Campinas, é possível verificar desde a implantação do cluster, a importância dos centros de pesquisa em nível nacional. Algumas empresas conseguiram expressão internacional recentemente, mas ainda são inexpressivas na participação do mercado global de seus setores. O caso de São Carlos teve início menos expressivo, sendo que até hoje são poucas as empresas de relevância nacional instaladas no cluster. $\mathrm{O}$ cenário tende a mudar para a região com a instalação da primeira indústria de semicondutores da América do Sul na região, mas ainda não há como prever o volume de outros investimentos destinados à região em função do empreendimento do consórcio Encalso-Symetrix. Apesar da possibilidade de ampliação de relevância do cluster frente ao mercado com a inserção de um novo agente de grande porte, é possível que este não estabeleça relações com outros agentes, e se o fizer provavelmente desequilibrará as relações de importância entre agentes constituídas internamente.

As redes de relações entre agentes consolidadas entre empresas, pessoas e instituições de ensino e pesquisa (questão 8) observadas nos clusters internacionais também foram constituídas de forma muito diferente do que a verificada nos casos nacionais. No caso do Vale do Silício, como já visto, há uma grande quantidade de relações formais e informais estabelecidas entre organizações e pessoas no interior do cluster, sob um sentimento de comunidade típico da cultura que permeia as instituições locais. Essas relações em múltiplos níveis permitem, entre outras coisas, a intensificação do fluxo de transferência de conhecimentos, sejam tácitos ou explícitos. Tendo em mente que os processos que levam à inovação dependem diretamente, conforme vários autores da literatura abordada, do nível de intensidade das relações entre agentes de inovação e do fluxo informacional decorrente dessas relações, pode-se dizer que o Vale do Silício possui a melhor configuração de relações para eclosão de inovações, dadas em uma multiplicidade de conexões que gera uma estrutura produtiva complexa. 
Bangalore possui um modelo de relações entre agentes muito parecido com o observado no Vale do Silício, talvez com um pouco mais de importância para a esfera governamental, que detém o controle dos centros de pesquisa e instituições de ensino de maior relevância. Entretanto, como visto anteriormente, as relações entre agentes não se orientam somente para o interior do cluster, tendo sido constituídas desde a implantação do pólo tecnológico voltadas para o ambiente externo.

No Brasil, como já mostrado ao longo do trabalho, as relações entre empresas ainda são incipientes, muito aquém do que pode ser considerado como ideal para se obter um nível de inovações que permita a participação competitiva do mercado global. A maioria dos agentes envolvidos com a dinâmica dos dois clusters nacionais abordados possui relações com as instituições de ensino e pesquisa de suas regiões, configurando modelos mononucleados de relações.

O fluxo de transferência de conhecimento entre agentes dos clusters abordados (questão 9) se dá de múltiplas formas nos clusters internacionais, e apenas no sentido empresa-instituição de ensino e pesquisa nos clusters nacionais, salvo raras exceções. É possível verificar que a origem do problema, mais uma vez, está diretamente relacionada com as diferenças entre as culturas organizacionais presentes nos casos internacionais e nacionais. No Brasil, o tipo de empreendedorismo encontrado é fruto de um esforço intenso de instituições ligadas ao governo e à sociedade civil no intuito de despertar nos empresários em potencial a vontade de deixar de ser empregados, professores ou pesquisadores, para se tornarem donos de seus próprios negócios, ao passo que essa é uma tendência natural na cultura típica do Vale do Silício, aprendida pelos argonautas indianos.

Dos sub-setores de TI que obtiveram maior destaque nos clusters abordados, percebese diferenças entre os quatro pólos tecnológicos. No caso do Vale do Silício, todas as áreas do setor de TI obtiveram expressão de mercado, denotando um desenvolvimento equilibrado e auto-sustentável das capacidades regionais. Significa dizer que é possível obter produtos inteiramente desenvolvidos na região competitivos frente ao mercado global. Isso não ocorre nos outros casos estudados.

A região de Bangalore se especializou em softwares e serviços, sub-setores de TI que dependem mais dos talentos humanos do que de recursos físicos. Esse é o segredo da competitividade de Bangalore, investir em áreas às quais representem vantagens ao cluster frente aos outros arranjos produtivos de tecnologia no mundo. Como a maior vantagem da região é a excelência de seus recursos humanos de baixo custo, nada melhor do que investir em sub-setores que valorizam isso. 
Os casos nacionais possuem a semelhança da especialização no desenvolvimento de softwares, tal qual Bangalore, mas em intensidade e relevância de mercado muito inferior. Além do desenvolvimento de software, Campinas e São Carlos também são referência nacional em montagem e desenvolvimento de equipamentos, na área de telecomunicações e equipamentos voltados para a indústria. Entretanto, no âmbito internacional as regiões ainda não possuem elevada relevância. No cluster de Campinas há algumas empresas nascidas na região que já se internacionalizaram, mas ainda dependem de investimentos maciços em vantagens competitivas para alcançar hegemonia de mercado. 


\subsection{Questões de 11 a 14}

O quadro 5 permite continuar a análise cross-case iniciada.

Quadro 5

\begin{tabular}{|c|c|c|c|c|}
\hline Questões & Vale do Silício & Bangalore & Campinas & São Carlos \\
\hline $\begin{array}{l}\text { 11. Qual a importância do } \\
\text { poder público e da } \\
\text { legislação vigente para a } \\
\text { manutenção do pólo } \\
\text { tecnológico? }\end{array}$ & Alta & Alta & Alta & Alta \\
\hline $\begin{array}{l}\text { 12. Qual a posição sócio- } \\
\text { econômica da região onde o } \\
\text { pólo tecnológico está } \\
\text { estabelecido frente ao } \\
\text { padrão nacional e aos } \\
\text { padrões das regiões dos } \\
\text { demais pólos tecnológicos } \\
\text { do mesmo setor (limitando- } \\
\text { se aos estudados)? }\end{array}$ & $\begin{array}{l}\text { Posição privilegiada. } \\
\text { Detêm uma das } \\
\text { maiores rendas per } \\
\text { capita do país, e boa } \\
\text { distribuição de renda. É } \\
\text { a região mais rica e } \\
\text { desenvolvida entre os } \\
\text { pólos analizados. }\end{array}$ & $\begin{array}{l}\text { No contexto nacional, } \\
\text { possui posição } \\
\text { privilegiada. No } \\
\text { contexto internacional, } \\
\text { possui problemas } \\
\text { quanto à equidade } \\
\text { social. É a região mais } \\
\text { pobre dentre os clusters } \\
\text { verificados. }\end{array}$ & $\begin{array}{l}\text { Posição privilegiada no } \\
\text { contexto nacional. } \\
\text { Problemas com } \\
\text { violência. Dentre os } \\
\text { clusters estudados } \\
\text { detêm a segunda melhor } \\
\text { situação sócio- } \\
\text { econômica, seguida de } \\
\text { perto por São Carlos. }\end{array}$ & $\begin{array}{l}\text { Posição privilegiada no } \\
\text { contexto nacional. Dos } \\
\text { clusters estudados está } \\
\text { logo atrás de Campinas, } \\
\text { mas bem a frente de } \\
\text { Bangalore no contexto da } \\
\text { distribuição de renda e } \\
\text { equidade social. }\end{array}$ \\
\hline $\begin{array}{l}\text { 13. Há relação entre os } \\
\text { fatores de desenvolvimento } \\
\text { social da região com o pólo } \\
\text { tecnológico? }\end{array}$ & Sim, elevada. & $\begin{array}{l}\text { Relação moderada. } \\
\text { Ainda há muito o que } \\
\text { ser feito sobre a } \\
\text { questão social na } \\
\text { região. } \\
\end{array}$ & Relação moderada. & Relação moderada. \\
\hline $\begin{array}{l}\text { 14. Como o pólo tecnológico } \\
\text { se integra com o } \\
\text { desenvolvimento de } \\
\text { pesquisa científica da região } \\
\text { que ocupa? Qual sua } \\
\text { participação no } \\
\text { estabelecimento de } \\
\text { implementos educacionais } \\
\text { da região? }\end{array}$ & $\begin{array}{l}\text { As necessidades das } \\
\text { empresas orientam as } \\
\text { descobertas. } \\
\text { Investimento maciço } \\
\text { das empresas e } \\
\text { governo em pesquisas } \\
\text { e desenvolvimento de } \\
\text { novas tecnologias. } \\
\text { Suporte das empresas } \\
\text { às universidades. }\end{array}$ & $\begin{array}{l}\text { Parcerias entre } \\
\text { universidades e } \\
\text { empresas, mas a } \\
\text { maioria das pesquisas } \\
\text { ocorre no âmbito das } \\
\text { empresas. As } \\
\text { universidades possuem } \\
\text { o papel, apoiado pelas } \\
\text { empresas, de } \\
\text { desenvolver } \mathrm{RH} .\end{array}$ & $\begin{array}{l}\text { Relações intensas entre } \\
\text { empresas e institutos de } \\
\text { ensino e pesquisa } \\
\text { financiados pelo poder } \\
\text { público. Ao invés da } \\
\text { empresa financiar a } \\
\text { universidade, verbas das } \\
\text { instituições colaboram } \\
\text { com o desenvolvimento } \\
\text { de tecnologias para as } \\
\text { empresas. }\end{array}$ & $\begin{array}{l}\text { Relações intensas entre } \\
\text { empresas e institutos de } \\
\text { ensino e pesquisa } \\
\text { financiados pelo poder } \\
\text { público. Ao invés da } \\
\text { empresa financiar a } \\
\text { universidade, verbas das } \\
\text { instituições colaboram } \\
\text { com o desenvolvimento } \\
\text { de tecnologias para as } \\
\text { empresas. }\end{array}$ \\
\hline
\end{tabular}

\section{Quadro de Análise Questões de 6 a 10}

Fonte: Autor

Pelo Quadro 5, é possível perceber que todos os clusters abordados foram estabelecidos com o apoio dos governos de seus países (questão 11), e ainda dependem desses, muito ou pouco, como consumidores do que é desenvolvido nos arranjos produtivos, como financiadores das tecnologias prospectadas ou como instituições de regulação das atividades internas, permitindo a reprodutibilidade dos modelos instituídos ao longo do tempo, ainda que arbitrariamente por força da lei (alguns modelos provavelmente colapsariam não fosse a instituição de normas que preservam sua integridade frente às interações negativas com o mercado). O poder público, seja qual for o cenário, é um elemento indiscutivelmente 
relevante, seja no estabelecimento de normas ou no financiamento do desenvolvimento regional.

No caso dos clusters nacionais, em especial de São Carlos, segundo o entrevistado Prof. Dr. Sylvio Goulart Rosa Jr., uma boa parte do desempenho do pólo tecnológico depende do volume de recursos oriundos do governo para que esse se consolide como um cluster de excelência. De fato, é perceptível no histórico do cluster americano os inúmeros aportes vultosos de recursos do governo para financiamento de pesquisas que derivariam em aumento do poderio de defesa do país, ou mesmo melhorias do aparato burocrático estatal. Entretanto, talvez isso não impacte tanto no desempenho do arranjo produtivo quando a disseminação do espírito empreendedor, sendo esse derivado de uma cultura regional voltada para a expansão da riqueza, elemento ainda em desenvolvimento nos pólos de tecnologia nacionais.

Quanto à posição sócio-econômica das regiões em que os clusters estão instalados frente aos padrões de seus países e frente aos demais pólos estudados (questão 12), é possível dizer que o Vale do Silício tem larga vantagem, tanto no quesito geração de receitas quanto no que tange à distribuição da renda. Apesar de poucas grandes riquezas serem identificadas no cluster da Califórnia, responsáveis pelo grande desvio padrão aferido pela renda per capita, percebe-se que o nível mínimo de condições de vida aferido na região é muito acima dos padrões verificados nos Estados Unidos e nos demais clusters avaliados.

Em relação a Campinas e São Carlos, há certa similitude quanto ao desenvolvimento sócio-econômico de ambas. Apesar de Campinas ser a décima cidade mais rica do país (IBGE, 1008), São Carlos é apontada pelos respondentes da pesquisa como a melhor cidade para se viver no Estado de São Paulo. De fato, São Carlos oferece uma estrutura social que vai do ótimo sistema de ensino fundamental até as baixas taxas de criminalidade. Campinas, especialmente a partir de 2001, segundo o respondente da pesquisa, tem desenvolvido diversos projetos para tentar equacionar o problema da má distribuição de renda, que é um dos principais fatores que contribuem para a alta taxa de criminalidade da região, segundo o entrevistado Sr. Décio Sirbone Jr. Apesar disso, possui um dos melhores sistemas viários do país, além de dispor de uma estrutura industrial que, como já visto anteriormente, é responsável pelo terceiro maior PIB do Estado (IBGE, 2008).

Bangalore, fosse por sua condição sócio-econômica ainda problemática, teria a menor probabilidade de abrigar um cluster de tecnologia. Entretanto, de acordo com o modelo estabelecido, a disparidade social acaba contribuindo para a consolidação das vantagens competitivas do cluster no âmbito global. Como verificado na revisão bibliográfica, a região abriga hotéis de sete estrelas coexistindo com a fome de milhares de crianças (KAMDAR, 
2008). Mesmo com uma condição de péssima distribuição de renda, que passa pelo limitado acesso das classes mais pobres às dignas condições de vida, a região possui instituições de ensino e pesquisa de relevância internacional, que favorecem à oferta de profissionais de alto nível a custos baixos para as empresas do setor de TI. As vantagens competitivas verificadas no cluster de Bangalore são, ao menos na análise do pesquisador, frutos da inserção tardia da Índia no contexto do capitalismo industrial, o que derivou em um tipo cruel de vantagem (baseada na baixa remuneração de um trabalho altamente qualificado que se fosse exercido em países do eixo do sistema teria seu preço dez vezes mais alto) que contribui para o crescimento das empresas, mas ainda não apresenta resultados significativos em relação à equidade social.

Sobre a existência de relação entre os fatores de desenvolvimento social das regiões em que os pólos tecnológicos estão instalados e seus agentes (questão 12), é possível dizer que os casos brasileiros possuem características similares, mas baseados em uma inversão do que a questão propunha aferir. Na verdade, são as boas iniciativas sociais das regiões de Campinas e São Carlos, derivadas em resultados satisfatórios, que acabaram por influenciar na escolha dos empreendedores em se fixar na região, segundo os entrevistados. As empresas estabelecidas ainda cooperam muito pouco com os fatores de desenvolvimento. Essa contribuição está quase sempre baseada na questão econômica, através da arrecadação de impostos para que os governos locais possam tomar medidas que tornem melhores as condições sociais, redistribuindo parte da renda gerada pela atuação dos agentes do pólo tecnológico. Algumas empresas possuem iniciativas próprias, mas destinadas ao atendimento de uma pequena parcela das populações residentes no entorno de suas instalações.

Já no Vale do Silício, as empresas contribuíram ativamente para as melhorias sociais da região, apesar de terem contribuído também para o aumento do risco ambiental de todo o Condado de Santa Clara. O aumento da receita proporcionado pelo Vale do Silício à região propiciou maior arrecadação de impostos que derivou na ampliação do atendimento às condições básicas de vida da população.

Em Bangalore, o maior investimento das empresas instaladas na melhoria social foi o estabelecimento de convênios com as instituições de ensino básico para oferecimento de melhores condições de alfabetização à população local. Entretanto, ainda não há medidas contundentes do governo no sentido de melhorar a distribuição de renda da região. A infraestrutura para condições básicas de saúde e saneamento ainda é precária, e começa a interferir no funcionamento das empresas do pólo de alta tecnologia. Apesar das elevadas receitas aferidas pelas empresas do cluster de tecnologia, os recursos não chegam à maior parte da 
população, constatação legitimada pela cultura indiana ainda muito influenciada pelo antigo regime de castas, que apesar da legislação nacional contrária, ainda faz parte do cotidiano da sociedade.

Em relação à integração dos pólos estudados com o desenvolvimento de pesquisas científicas e suas participações no implemento educacional das regiões em que estão instalados (questão 14), é possível verificar similitude nos modelos estabelecidos em São Carlos e Campinas. A maior parte das pesquisas desenvolvidas nos clusters nacionais depende das instituições de ensino e pesquisa, realizadas em parceria com as empresas que desfrutarão das benesses da comercialização do que for descoberto. Esse modelo favorece a atuação das empresas, que vêm seus custos com prospecção e desenvolvimento de tecnologias reduzidos, devido à participação do poder público, que financia as instituições centrais do Sistema Regional de Inovação. Assim, as empresas são beneficiadas pelo compartilhamento dos custos de pesquisa e desenvolvimento com as universidades, nem sempre devolvendo alguma contrapartida direta.

Já nos modelos do Vale do Silício e Bangalore, é preponderante a participação das empresas no processo de inovação. As universidades e centros de pesquisa funcionam como unidades de suporte para obtenção daquilo que é demandado pelas empresas, alinhadas com as necessidades do mercado. Dessa forma, principalmente no Vale do Silício, as empresas passam a atuar como financiadoras das unidades de pesquisa e instituições de ensino para que essas cooperem na obtenção de novas vantagens de mercado relacionadas à inovação.

O caso particular de Bangalore demanda uma análise mais profunda, pois há maior dependência das instituições de ensino e pesquisa, por conta da vantagem do cluster estar focada na abundância de mão-de-obra especializada a baixo custo, formada pelas universidades e centros de formação técnica locais. Além da questão da formação dos recursos humanos, é possível verificar que muitas das relações estabelecidas entre os empreendedores da região se iniciaram nas instituições de ensino, antes de serem transferidos para empresas e centros de pesquisa nos Estados Unidos e na Europa. Por conta das relações estabelecidas na origem do cluster, é possível dizer que as instituições de ensino são portadoras das chaves que geraram a grande vantagem competitiva da região, que é a excelência dos empreendedores, que tiveram acesso aos seus primeiros conhecimentos de ordem técnica na região. 


\section{CONCLUSÕES}

Os quatro clusters estudados possuem semelhanças e diferenças das quais emergem elementos passíveis de serem analisados frente às premissas do desenvolvimento sistêmico. Segundo observado no tópico 2.2.4, é possível elencar de forma objetiva alguns elementos típicos do conceito de desenvolvimento sistêmico:

- expansão do modelo de forma sinérgica, com as partes alinhadas em função da manutenção sistêmica;

- obtenção de melhores condições de existência a cada ciclo operacional;

- capacidade de adaptação, flexibilidade;

- capacidade de absorver e disseminar informações;

- equidade interna;

- melhoria de vida das pessoas conectadas ao contexto sistêmico, seja no âmbito social, econômico, educacional ou ambiental.

Esses elementos devem se articular para que haja a reprodutibilidade do sistema ao longo do tempo. Da articulação, é possível perceber que os elementos destacados estabelecem uma rede de relações de causa e efeito. Para que haja expansão de forma sinérgica do sistema, é necessário que se estabeleçam relações internas entre os agentes, e para isso é necessário que os mesmos consigam absorver e disseminar informações de forma efetiva. $\mathrm{O}$ bom fluxo de informações torna possível maior adaptabilidade ao sistema, uma vez que todos os agentes conseguem obter informações sobre o ambiente e preparar-se para a interação com esse. Com maior disponibilidade de informações, todos os agentes possuem vantagens similares frente aos outros, impedindo que haja hegemonia de apenas um agente central, tendo sua importância diluída pelas oportunidades igualadas. Sem concorrência desleal, conseqüência da boa disseminação de informações e equidade de importância dos agentes, é possível a obtenção de melhores condições de existência a cada ciclo operacional, aumentando os ciclos de vida das organizações. A equidade de relevância traz também a oportunidade de melhor distribuição dos resultados, contribuindo para a melhoria das condições de vida das pessoas envolvidas no contexto sistêmico nos diversos âmbitos possíveis.

Diante do que foi exposto na análise cross-case dos resultados obtidos pelo instrumento de pesquisa aplicado aos clusters abordados, é possível perceber que nenhum dos modelos atinge um alinhamento perfeito com as premissas do desenvolvimento sistêmico abordadas. Há na verdade uma gradação de aproximação ao tipo ideal de desenvolvimento 
sistêmico. O modelo estabelecido no Vale do Silício é o que mais se aproxima do conceito de desenvolvimento sistêmico, enquanto os demais modelos avaliados ainda possuem nítidas dificuldades a serem vencidas para que possam atingir a condição de manutenção sistêmica intrínseca ao conceito.

O Vale do Silício teve sua expansão de forma sinérgica, apoiada no estabelecimento de relações de cooperação e na estruturação de cadeias produtivas que vão desde a pesquisa e desenvolvimento de produtos e serviços à sua veiculação no mercado. O alinhamento dos agentes do cluster em torno do desenvolvimento regional é derivado de uma cultura voltada para o empreendedorismo e a busca constante de melhores condições de vida, contribuindo para a eclosão de novas oportunidades de negócio na região. O estabelecimento de relações em diversos níveis com diversos agentes diferenciados possibilitou maior equidade de relevância no interior do cluster, pois cada organização desempenha diferentes papéis nas múltiplas relações que exercem com os demais ocupantes do cluster. O Vale do Silício é o exemplo emblemático desse modelo de relações entre agentes de um cluster, o que possibilitou observar a igualdade de relevância entre as organizações, o que denota baixo nível de dependência interna por não haver agentes centrais cuja importância seja superior a dos demais envolvidos no arranjo produtivo. Pela análise do modelo de desenvolvimento do cluster, foi possível verificar que apesar da importância do governo e das instituições de ensino e pesquisa, o Vale do Silício não depende excessivamente de uma ou outra unidade representativa dessas instituições. Como exemplo, é possível dizer que caso a Universidade de Stanford fechasse as portas, outras instituições de ensino e pesquisa a substituiriam, sem que o cluster inteiro entrasse em colapso.

Uma das peculiaridades mais marcantes do cluster californiano é o tipo de relações estabelecidas entre os agentes de inovação, que vão das formais às informais. Isso permite com que o fluxo de conhecimento no interior do cluster seja intenso e contínuo, tanto em seu modo tácito quanto explícito. As relações estabelecidas em múltiplos níveis levam à maior capacidade de adaptação frente às mudanças do ambiente externo. Essas mudanças podem estar inseridas no contexto de transferência de competitividade para outras regiões concorrentes do mesmo setor, que como visto anteriormente ocorreu com o surgimento do cluster de Bangalore, baseado em custos inferiores de desenvolvimento e pesquisa. Com todas as características descritas, somadas ao pioneirismo da região em determinados setores da eletrônica e computação - o que rendeu um histórico de ganhos sem precedentes em outros arranjos produtivos do mesmo nicho de mercado - foi possível gerar melhorias para toda a 
sociedade, senão de forma igualitária ao menos aumentando os padrões vigentes na base e no pico da hierarquia social.

O cluster de Bangalore, apesar de estar constituído em um regime de relevância distribuída entre as empresas atuantes, possui particularidades ligadas ao desenvolvimento histórico da região que contribuem para afastá-la do modelo ideal de desenvolvimento sistêmico. Ainda que as relações entre empresas sejam equilibradas internamente, essa equidade de relevância nas relações não se desdobrou em uma distribuição igualitária das benesses geradas pelo estabelecimento do cluster. Há profundas contradições sociais, que vão contra o preceito sistêmico de melhoria da qualidade de vida das pessoas direta ou indiretamente relacionadas com a atividade do cluster. O tipo de desenvolvimento encontrado na região corrobora com a constatação de Krugman (1999) de que há uma lógica desumana no capitalismo, seja qual for o seu estágio, e no caso do informacionalismo essa lógica se apóia na redução dos custos do fator humano inserido na produção, até mesmo na produção de inovação tecnológica. Os resultados são a falta de equidade em Bangalore e desestruturação do macro-sistema no qual o cluster está inserido, tema que foge ao escopo da análise aqui proposta.

Bangalore também possui boa capacidade de adaptação a novos contextos, boa capacidade de disseminar e absorver informação - tanto no que se refere às relações com o ambiente externo quanto no que se refere às relações estabelecidas internamente - e tem conseguido expandir suas atividades de forma sinérgica, pra dentro e para fora do cluster. Nem por isso, pode-se dizer com certeza que há melhoria das condições de existência do sistema a cada ciclo, por conta da má distribuição das benesses do progresso comercial e tecnológico auferido pelas empresas de TI.

Os clusters brasileiros possuem mais similitudes do que diferenças, por terem se desenvolvido em contextos históricos parecido, mas não idênticos. A região de Campinas leva vantagem sobre a região de São Carlos pelo volume de sua produção econômica regional, apoiada no desenvolvimento industrial prévio à instalação do cluster. Entretanto, São Carlos possui melhores condições sociais, por ter um volume demandado de recursos mais compatível com a sua disponibilidade. O desenvolvimento de seus parques tecnológicos se distancia historicamente dos processos verificados nos casos internacionais, e se opõe aos principais elementos de configuração do conceito de desenvolvimento sistêmico.

Ambos os clusters nacionais abordados se configuram de forma mononucleada, por haver notória importância das instituições de ensino e pesquisa (financiadas pelo governo) nas relações estabelecidas internamente. As relações entre empresas e as cadeias produtivas para 
prospecção de inovação são raras. As relações existentes entre agentes são mediadas pelas instituições de ensino e pesquisa, que além de concentrarem a maioria das atividades de desenvolvimento e pesquisa concentradas nos clusters, formam mais profissionais do que as regiões conseguem absorver. Segundo o resultado dos casos nacionais, Campinas e São Carlos formam funcionários de alta capacidade técnica, mas não conseguem formar empreendedores que consigam alavancar o número de empresas de base tecnológica de seus respectivos clusters.

Sem o estabelecimento de relações entre empresas, não há expansão sinérgica. A expansão verificada é resultado das iniciativas dos agentes centrais dos modelos consolidados, as instituições de ensino e pesquisa. Com preponderância dos agentes centrais, a equidade fica comprometida, extinguindo a possibilidade de um ambiente concorrencial equilibrado. Com o desequilíbrio, o conhecimento deixa de ser disseminado por igual entre os agentes, e a tendência não se modifica sem a instauração de novas relações entre os agentes de inovação. As poucas relações que surgem são, mais uma vez, orientadas das empresas e empreendedores para as instituições de ensino e pesquisa - aumentando o grau de dependência estrutural do sistema.

Por trás da distância verificada entre os modelos consolidados nos clusters nacionais e o modelo tido como ideal pelos preceitos do desenvolvimento sistêmico, é possível verificar um elemento que propiciou maiores vantagens aos clusters internacionais quanto à reprodutibilidade de seus modelos ao longo do tempo: a cultura organizacional disseminada na região.

A cultura da região do Vale do Silício, que teve muitos de seus elementos levados à cultura organizacional de Bangalore, preza pelo empreendedorismo, pelo estabelecimento de relações em diversos níveis (formais e informais, de cooperação ou de fornecimento) e pelo fluxo intenso de informações. Apesar da péssima distribuição de renda evidenciada em Bangalore, o arranjo produtivo estabelecido no cluster tem claramente o aspecto multinucleado, o que deriva em vantagens relativas à baixa dependência estrutural do modelo consolidado. No Vale do Silício, essa dependência estrutural tende a ser ainda menor, por conta do processo intenso de reformulação das relações entre os múltiplos agentes do cluster.

No Brasil, a cultura organizacional ainda emperra no sentido de estabelecer laços com os outros agentes do ambiente. Em clusters de tecnologia, onde a cooperação pode significar o surgimento de vantagens coletivas no âmbito regional, é essencial que os fatores de inovação se aproximem, estabeleçam parcerias e, principalmente, troquem informações que possibilitem o reconhecimento de oportunidades. Infelizmente, a tendência verificada na 
maioria das empresas ocupantes dos clusters estudados é a da política da "contrainteligência", que coloca os parceiros em potencial como concorrentes natos, inviabilizando o estabelecimento de relações que poderiam se desdobrar em inovações de estrutura, produtos e processos, possibilitando maior competitividade para a região.

Quando essa realidade nacional é confrontada com os conceitos que significam os termos associados às aglomerações de empresas, é possível dizer que os clusters brasileiros estão aquém do grande diferencial oferecido pelos Sistemas Regionais de Inovação, que é a possibilidade de estabelecer conexões não apenas com instituições de ensino e pesquisa, mas com possíveis parceiros da iniciativa privada, com experiências de mercado diferenciadas que podem significar a solução para a obtenção de vantagens competitivas em escala regional. De fato, os casos dos clusters nacionais estão mais próximos do compartilhamento dos custos relativos à ocupação espacial do que das possibilidades de se atingir a excelência tecnológica necessária para se competir em âmbito global, como foi possível constatar inúmeras vezes ao longo da análise realizada. E essa deficiência, como já visto anteriormente, é derivada de um tipo de cultura organizacional que não privilegia o empreendedorismo, com intensa aversão ao risco.

Apesar de não haver coerência completa entre nenhum dos modelos verificados e o modelo ideal de desenvolvimento sistêmico, é possível afirmar através da análise a que se propôs esse trabalho, que as relações estabelecidas entre os agentes dos arranjos produtivos de tecnologia são um reflexo do tipo de cultura organizacional verificada nas regiões onde os clusters se instalam. Essa percepção pode servir como orientação para a implantação de ações para o desenvolvimento dos clusters sob as premissas do pensamento sistêmico. Sem uma reformulação de valores culturais, inserindo elementos de valorização do empreendedorismo, do estabelecimento de relações de parceria e do fluxo livre de informações, fica difícil pensar em um modelo de desenvolvimento que seja sustentável ao longo do tempo.

No Brasil, as iniciativas dos governos em fomentar empreendimentos de tecnologia não são suficientes, pois apesar de alavancarem o número de empresas de base tecnológica, exacerba ainda mais a importância das relações estabelecidas com as instituições de ensino e pesquisa que servem como canalizadoras para os investimentos estatais nos clusters. Além desse tipo de iniciativa, é necessário o estabelecimento de relações entre os agentes, tanto nas questões produtivas quanto nas relacionadas com a prospecção de inovação. Esse é o diferencial que separa os arranjos produtivos efetivos da mera divisão de custos operacionais.

O objetivo geral a que se propunha a pesquisa era, através da análise comparativa entre os clusters abordados, identificar elementos que pudessem ser analisados à luz do 
conceito de desenvolvimento sistêmico, respondendo à questão de pesquisa sobre como se dão as relações internas entre agentes dos clusters e se essas contribuem ou não para a manutenção sistêmica dos arranjos produtivos. Diante das conclusões acima, é possível dizer que o objetivo geral foi completamente atingido. Os objetivos específicos, elencados no tópico 1.2.2 foram igualmente atingidos, colaborando para a resposta ao problema de pesquisa, igualmente identificada através das conclusões obtidas.

\subsection{Limitações de Pesquisa}

A pesquisa desenvolvida, por se basear nas percepções dos entrevistados e do pesquisador frente à bibliografia adotada, se caracteriza como qualitativa e, portanto, poderá ter seus resultados criticados diante de opiniões que divirjam daquelas que compõem as referências de análise.

Os resultados e verificações obtidos nessa pesquisa não podem servir como uma representação geral da formação de clusters em outras regiões do mundo, senão naquelas em que se baseiam as opiniões que compuseram o referencial de pesquisa, o que não significa que não permita perceber similitudes entre os elementos constituintes dos tipos de desenvolvimentos analisados e outros contextos no âmbito nacional e internacional.

Não se procurou ao longo da pesquisa estabelecer um guia sobre boas práticas de administração de arranjos produtivos de tecnologia, uma vez que o universo de análise não compreende - assim como não teria como compreender - todos os modelos de desenvolvimento de clusters tecnológicos. A busca por um guia que estabeleça parâmetros rígidos de gestão tecnológica se mostra infrutífera, ao menos no contexto desta pesquisa, pela inviabilidade de reduzir todos os contextos e especificidades de cada região passível de abrigar um pólo tecnológico a um único ambiente universalizado, onde as regras que servem para um caso possam servir para todos. Dessa forma, o que se procurou nesta pesquisa foi ancorar as análises aos casos abordados e ao conceito de desenvolvimento sistêmico, sem a pretensão de gerar um conjunto de sugestões que sirvam a qualquer sistema de inovação.

A pesquisa não se voltou para a validação das opiniões expressas pelos entrevistados, nem se pautou em métodos específicos para consolidação da percepção do pesquisador acerca do que vivenciou nas visitas aos pólos nacionais abordados. Outros temas chamaram a atenção do pesquisador e poderiam ser explorados em momentos mais oportunos, mas não couberam no escopo desta pesquisa, sendo alguns deles mostrado a seguir. 


\subsection{Novas discussões propostas pela pesquisa}

A pesquisa desenvolvida culminou em outras perspectivas e temas a serem abordados em futuros trabalhos, transpassando a proposta inicial de um estudo de múltiplos casos sobre pólos de tecnologia da informação. Desde a primeira etapa, a procura por informações que levassem à maior compreensão dos assuntos relacionados ao tema de pesquisa acabou por incitar o pesquisador a propor outras questões frente ao que era visto. Algumas dessas questões podem se desdobrar em novos trabalhos, assim como apresentado a seguir. $\mathrm{O}$ surgimento de novas questões a respeito do tema denota que ainda há muitos elementos a serem analisados para que se esgotem as pesquisas sobre arranjos produtivos.

Os tópicos apresentados abaixo se justificam na inquietude do pesquisador em buscar explicações para a ausência de equidade de relevância no interior dos modelos estudados, fato que demonstra que ainda há muito a ser feito para que os modelos reais de arranjos produtivos se aproximem mais dos modelos ideais de desenvolvimento sistêmico.

\subsubsection{Dependência Estrutural Interna}

O conceito de dependência estrutural foi cunhado na sociologia, quando observadas as classes internas e externas que compõem o Estado Nacional (CARDOSO; FALLETO, 2004). $\mathrm{Na}$ economia, o conceito foi amplamente discutido no âmbito das relações entre países precocemente industrializados e aqueles considerados de industrialização tardia (CARDOSO DE MELLO, 1982), o que dimensionou uma divisão internacional do trabalho que concentrava as funções mais próximas da tecnologia de ponta no eixo do sistema e as demais funções na periferia (FURTADO, 2008). A idéia, frente à dinâmica dos arranjos produtivos, é recuperada de forma mais objetiva, no âmbito das redes de organizações. Não se trata de abandonar os preceitos que a economia política desenhou para o tema, mas da necessária adequação ao nível organizacional.

Em modelos produtivos mononucleados, a presença da grande organização nuclear é a força motriz do sistema. Suas relações alcançam, direta ou indiretamente, todas as unidades produtivas incluídas no sistema. Dessa forma, torna-se o grande referencial das demais 
unidades do sistema, tanto diante das especificações de produtos, processos e estruturas, quando diante da visualização do mercado. Seja num cluster (concentração regional de empresas) ou em outro modelo de arranjo produtivo, as empresas que exercem a função de núcleo sistêmico carregam sobre si a responsabilidade da manutenção de todas as unidades conectadas a si.

Dos arranjos produtivos mononucleados, chega-se à variante mais drástica da temática que é o mercado mononucleado. Apenas uma unidade central fornece a maior parte dos produtos de um determinado segmento. Significa aumento relativo da importância da organização central do sistema produtivo frente aos seus concorrentes, dada a amplitude de sua atuação no mercado. Essa organização passa a influenciar de forma desmedida o nível de preços, o que não é interessante para o consumidor.

Nos mercados mononucleados, o consumidor é o grande prejudicado, por não possuir opções de mesmo nível técnico aos produtos oferecidos pelo agente central do mercado, uma vez que este compete apoiado no volume operacional, possibilitando custos mais baixos com qualidade melhor. Muitas vezes, a diferença de custos não é repassada para a formação de preços, diante da possibilidade do agente central ditar o preço do mercado por não possui concorrentes aptos a equalizar, concorrencialmente, oferta e demanda a um preço mais baixo. Dessa forma, o poder de mercado do agente central tende a significar o poder de estabelecimento dos níveis médios de preços praticados.

O mercado mononucleado é um estágio futuro do modelo produtivo mononucleado. A concentração de capital para fins produtivos, aglutinando os recursos sobre um único agente sistêmico, desdobra-se em impedimentos para o estabelecimento de novos concorrentes de menor porte. Em sistemas mononucleados, a estrutura criada possui alto grau de dependência em relação ao agente central. Significa dizer que se por algum motivo a organização no núcleo do sistema entrar em colapso, há um risco elevado de todo o sistema ruir. Se apesar da dependência interna do arranjo produtivo houver agentes externos que compitam no mercado de forma relevante, é possível que haja substituição do agente em colapso. Entretanto, no âmbito interno do arranjo produtivo, é possível que os demais agentes de menor porte não consigam subsistir à crise do modelo.

Os modelos multinucleados possuem dependência interna diminuída, em função da inexistência de um agente que concentre o poder decisório. Modelos multinucleados de produção dificilmente se desdobram em modelos mononucleados de mercado. Obviamente, se um player se destaca dos demais a ponto de concentrar para si a maioria absoluta da participação do mercado, isso acaba se desdobrando em aumento de sua importância frente ao 
seu segmento de atuação, mas nem sempre isso origina o aumento de importância no modelo produtivo em que opera.

\subsubsection{A busca por dispositivos de mensuração}

Ainda não existe na literatura da área de clusters e arranjos produtivos um estudo definitivo sobre possíveis índices de mensuração da dependência estrutural interna. Verificase que, dada a necessidade de uma análise criteriosa do nível de intensidade das relações estabelecidas entre empresas, quaisquer dispositivos passíveis de ser utilizados para composição de um índice que reflita a condição de dependência interna de um arranjo produtivo fatalmente passa pela adoção de parâmetros deterministas e impositivos, como a atribuição de pesos numéricos para uma determinada característica de relação. Entretanto, existem formas menos propensas à conceituação pessoal, como a análise do número de relações estabelecidas.

Analisando o modelo de arranjo produtivo mononucleado, as relações estabelecidas entre os agentes tendem a ser unidirecionadas no sentido do participante central (Figura 1). A temática a ser abordada na análise de número de relações possíveis é a de controle do poder político/normativo. Quanto maior a intensidade das relações estabelecidas em uma única via com o agente central do sistema, maior a dependência das unidades periféricas em relação ao núcleo. Se por algum motivo as unidades participantes do arranjo produtivo estabelecem outras relações de fornecimento ou dependência com outros agentes, o agente central perde relevância, pois o grau de dependência da relação diminui. No formato de controle ideal, onde o agente central é o intermediário exclusivo das relações entre as empresas inseridas no contexto do modelo mononucleado, todos os participantes diretos do processo produtivo possuem relação exclusiva com o núcleo. Dessa forma, o número de relações ideais estabelecidas é igual à quantidade de agentes no sistema produtivo menos um, todas em função do agente central.

Da mesma forma, o modelo de arranjo produtivo multinucleado tem um modelo ideal de relações, em que todas as unidades possuem relações de dupla via com todas as demais unidades do sistema. O número ideal de relações, que é também o número máximo de relações possíveis é dado pela equação: 


$$
\frac{\mathrm{n}(\mathrm{n}-1)}{2}
$$

Considera-se, desse modo, que as relações de dupla via são na verdade apenas uma relação, um tipo específico em que há dupla direção do fluxo informacional, e que n é o número de agentes do sistema. Entre dois agentes pode existir no máximo uma relação, com diferentes comportamentos de intensidade e direção dos fluxos.

Considerando os dois aspectos considerados como ideais, podemos situar o número de relações de um arranjo produtivo entre os dois extremos verificados. Assim, uma escala de número de relações (Q) dada estabelecidas em um arranjo produtivo seria:

$$
(n-1)<0<\frac{n(n-1)}{2}
$$

Ainda que tenhamos uma escala para mensuração do nível de dependência interna pelo número de relações, não há como determinar a priori que valores de @ próximos de seus extremos configuram o modelo produtivo como mais dependente ou menos dependente, mas sim que quanto maior o valor de o dentro da escala, mais próximo está de ser um arranjo produtivo multinucleado.

O desenvolvimento de um fator de ponderação de $Q$ que leve em conta os graus de importância das relações de forma vetorial deverá contribuir em muito para o estabelecimento de um indicador de nível de dependência interna em arranjos produtivos. Contudo, esse tema não era objeto primário ou secundário dessa pesquisa, e fica aqui registrado como uma proposta para futuros trabalhos. 


\section{REFERENCIAS}

ÁCS, Zoltán J.; GROOT, Henri L. F.; NIJKAMP, Peter. The Emergence of the Knowledge Economy: a Regional Perspective. Nova York: Springer, 2002.

Allan, Roy A. A History of the Personal Computer: The People and the Technology. Toronto: Allan Publishing, 2001.

AMATO NETO, João. Reestruturação industrial, terceirização e redes de subcontratação. Revista de Administração de Empresas. v. 35, n. 2, p. 33-42, mar./abr. 1995.

ANTUNES, Fernando. Americana Symetrix construirá fábrica de semicondutores em São Carlos. Folha Online, São Paulo, 2 out. 2008, Disponível em: < http://www1.folha.uol.com. br/folha/dinheiro/ult91u451502.shtml. Acesso em: 5 out. 2008.

ARCHER, Margaret S. Structure, agency and the internal conversation. Cambrige: Cambridge University Press, 2003.

ASHEIM, B.T; GERTLER, M.S. The Geography of Innovation: Regional Innovation Systems. In: FAGERBERG, J; MOWERY, D.C; NELSON, R.R. (Eds.). The Oxford Handbook of Innovation. Oxford: Oxford University Press, 2005.

ASHWANI, Saith; VIJAYABASKAT, M. ICTs and Indian Economic Development. New Delhi: Sage Publications, 2005.

BALASUBRAMANYAM, V.N.; BALASUBRAMANYAM, Ahalya. The software cluster in Bangalore. In: DUNNING, John B. (Ed.). Regions, Globalization, and the KnowledgeBased Economy. New york: Oxford University Press, 2002

BASANT, Rakesh. Bangalore Cluster: Evolution, growth and challenges. In: YUSUF, Shahid; NABESHIMA, Kaoru; YAMASHITA, Shoichi (Eds.). Growing Industrial Clusters in Asia: Serendipity and Science. p. 147-193. Washington DC: World Bank, 2008.

BATHELD, H; MALMBERG, A; MASKELL, P. Clusters and knowledge: local buzz, global pipelines and the process of knowledge creation. Progress in Human Geography. n. 28, v. 1, pp. 31-56, 2004.

BAUMAN, Zygmunt. Globalização: As conseqüências humanas. Rio de Janeiro: Jorge Zahar Ed., 1999.

BECATTINI, G. "The Marshallian industrial districts as a socio-economic notion". In: PYKE,F.; BECATTINI, G.; SENGENBERGER, W. (Ed.). Industrial districts and interfirm cooperation in italy. Geneve: International Institute of Labour Studies, p. 37-51, 1990.

BENKO, Georges. Economia, espaço e globalização na aurora do século XXI. São Paulo: Hucitec, 1995. 
BOSHMA, R.A. Proximity and Innovation: A Critical Assessment. Regional Studies, v. 1, n. 39, p. 61-74, 2005.

BOYER, Robert. Between imitation and innovation: the transfer and hybridization of productive models in international automobile industry. New York: Oxford University Press, 1998.

BRESNAHAN, Timothy; GAMBARDELLA, Alfonso. Building High-Tech Clusters: Silicon Valley and Beyond. Cambridge: Cambridge University Press, 2004.

BUCKLAND, Michael. Information and Information Systems. New York: Greenwood Publishing Group, 1991.

BUCKLEY, Walter. A Sociologia e a Moderna Teoria dos Sistemas. São Paulo: Editora Cultrix e Editora da USP, 1971.

BYLINSKY, Gene. The innovation millionaires: How they succeed. New York: Scribner, 1976.

CANO, Wilson; BRANDÃO, Carlos A. A Região Metropolitana de Campinas: Urbanização, Economia, Finanças e Meio Ambiente. Campinas: Unicamp, 2002.

CARDOSO, Fernando H.; FALLETO, Enzo. Dependência e Desenvolvimento na América Latina. São Paulo: Record, 2004.

CARDOSO DE MELLO, João Manuel. O Capitalismo Tardio: contribuição à revisão crítica da formação e do desenvolvimento da economia brasileira. São Paulo: Brasiliense, 1982.

CARLIN, Wendy; SCHAFFER, Mark; SEABRIGHT, Paul. A Minimum of Rivalry: Evidence from Transition Economies on the Importance of Competition for Innovation and Growth. Contributions to Economic Analysis \& Policy. v. 3, n. 1, set. 2004.

CARONIA, A. Il Corpo Virtuale. Pádua: Munzio, 1996.

CASARotto Filho, N.; PIRES, L. H. Rede de Pequenas e Médias Empresas e Desenvolvimento Local. São Paulo: Atlas, 1999.

CASSIOLATO, José Eduardo; LASTRES, Helena M.M.; STALLIVIERI, Fabio. Introdução: Políticas estaduais e mobilização de atores políticos em arranjos produtivos e inovativos locais. In: CASSIOLATO, José Eduardo; LASTRES, Helena M.M.; STALLIVIERI, Fabio (Orgs). Arranjos Produtivos Locais: uma alternativa para o desenvolvimento: experiências políticas. v. 2. Rio de Janeiro: E-Papers, 2008.

CASTELLS, Manuel. The Informational City: Information Technology, Economic Restructuring, and the Urban-regional Process. New York: Blackwell Publishing, 1991.

CASTELLS, Manuel. A Sociedade em Rede. São Paulo: Paz e Terra, 1999. 
CASTELLS, Manuel. A galáxia da internet: reflexões sobre a internet, os negócos e a sociedade. São Paulo: Jorge Zahar, 2003.

CASTRO, Ana Célia. Brasil em desenvolvimento. São Paulo: Record, 2005.

CASTRO, Pedro. Sociologia sobre e sub urbana. Rio de Janeiro: UFF, 1993.

CAVALCANTI, Cordélia Robalino. Da Alexandria do Egito à Alexandria do Espaço: um exercício de revisão de literatura. São Paulo: Thesaurus, 1996.

CHANDLER, Alfred Dupont; CORTADA, James W. A Nation Transformed by Information: How Information has Shaped the United States from Colonial Times to the Present. New York: Oxford University Press US, 2003.

CHECKLAND, Peter. Systems Thinking, Systems Practice. Chichester: John Wiley \& Sons, 1981.

CHECKLAND, Peter. Soft Systems Methodology in Action. Chinchester: John Wiley \& Sons, 1999.

COOKE, Philip; HEIDENREICH, M.; BRACZYK, H.J. Regional Innovation Systems, London: Routledge, 2004.

COOKE, Philip. Regional transformation and regional disequilibrium: New knowledge economies and their discontents. In: FUCHS, Gerhar; SHAPIRA, Philip. Rethinking regional innovation and change: Path dependency or regional breakthrough?. New York: Spring, 2005.

COOPEY, Richard. Information Technology Policy: Competing for the Future. In: COOPEY, Richard (Org.). Information Technology Policy: An International History. p. 1-23. Oxford: Oxford University Press, 2004.

CORIAT, B. La Robotique. Paris: Repères, 1983.

CRUZ, Renato. TV Digital no Brasil: tecnologia versus política. São Paulo: Senac, 2008.

DALSGAARD, Mette Holm. Danish Cluster Policy: Improving Specific Framework Conditions. In: HERTOG, Pim den; BERGMAN, Edward M.; REMOE, Svend (Orgs). Innovative Clusters: Drivers of National Innovation Systems. p. 347-359. New York: OECD, 2001.

DAMÁSIO, António. O Erro de Descartes. São Paulo: Companhia das Letras, 1996.

DANTAS, Marcos. A Lógica do Capital-Informação. Rio de Janeiro: Ed. Contraponto, 2002.

DEMARIO, Camila G.; RIBEIRO, Christian C.G.; EMILIANO, Elisamara de O. A implementação do Estatuto da Cidade na Região Metropolitana de Campinas. In: BUENO, Laura M.M.; CYMBALISTA, Renato. (Orgs.). Planos diretores municipais: novos conceitos de planejamento territorial. p. 89-107. São Paulo. Annablume, 2007. 
DINIZ, Clélio C.; GONÇALVES, Eduardo. Economia do conhecimento e desenvolvimento regional no Brasil. In: DINIZ, Clélio C.; LEMOS, Mauro B. Economia e Território. Belo Horizonte: UFMG, 2005.

DOZENA, Alessandro. São Carlos e seu desenvolvimento: contradições urbanas de um pólo tecnológico. São Paulo: Annablume, 2008.

DRUCKER, Peter. Inovação e espírito empreendedor (entrepreneurship): prática e princípios. São Paulo: Cengage Learning Editores, 1987

EDQUIST, C. Systems of Innovation: Perspectives and Challenges. In: FAGERBERG, J; MOWERY, D.C; NELSON, R.R. (Eds.). The Oxford Handbook of Innovation. Oxford: Oxford University Press, 2005.

EPSTEIN, Marc J.; DAVILA, Tony; SHELTON, Robert D. As Regras da Inovação: como gerenciar, como medir e como lucrar. São Paulo: Artmed, 2006.

FIGUEIREDO, Paulo N. Aprendizagem Tecnológica e Inovação no contexto de industrialização recente. In: CAVALCANTI, Bianor Scelza; RUEDIGER, Marco Aurélio; SOBREIRA, Rogério (Orgs.). Desenvolvimento e construção nacional: políticas públicas. Rio de Janeiro: FGV, 2005.

FIUZA, César. Direito Civil: Curso Completo. Belo Horizonte: Del Rey, 2008.

FIUZA, Tatiana. Área de CT\&I da Pitce contará com R\$ 1,8 bilhão. Gestão C\&T Online. Brasília, 12 set. 2007. Disponível em: < http://www.gestaoct.org.br/eletronico/jornais/ numero648.htm\#mat2>. Acesso em: 6 jun. 2008.

FLAMM, Kenneth. Targeting the Computer: Government Support and International Competition. Washington: Brookings Institution Press, 1987.

FLAMM, Kenneth. Creating the Computer: Government, Industry, and High Technology. Washington: Brookings Institution Press, 1988.

FRANÇA, Paulo. Captação de Recursos em Projetos e Empreendimentos. Brasília, DF: Senac, 2005.

FRANDA, Marcus F. Governing the Internet: the emergence of an international regime. Boulder: Lynne Rienner, 2001.

FRITSCH, M; SCHWIRTEN, C. Enterprise-University Co-operation and the Role of Public Research Institutions in Regional Innovation Systems. Industry and Innovation, v. 6, n. 1, p. 69-83, 1999.

FURTADO, Celso. Criatividade e dependência na civilização industrial. São Paulo: Companhia das Letras, 2008.

FURTADO, Vasco. Tecnologia e gestão da informação na segurança pública. São Paulo: Garamond, 2002. 
FUSCO, José Paulo A. Cadeias de fornecimento e redes de empresas: abordagem metodológica para avaliação de competitividade. São Paulo: Arte \& Ciência, 2004.

GARDNER, Howard. A nova ciência da mente: uma história da revolução cognitiva. São Paulo: Edusp, 1996.

GERRING, John. Case Study Research: Principles and Practices. Cambridge: Cambridge University Press, 2007.

GERTLER, M.S. Tacit Knowledge and the Economic Geography of Context, or the Undefinable Tacitness of Being. Journal of Economic Geography, n. 3, p. 75-99, 2003.

GIANCOLA, Joseph M.; HUTCHISON, Janice K. Transforming the culture of school leadership: humanizing our practice. Thousand Oaks: Corwin, 2005.

GODOY, Arilda S. Pesquisa Qualitativa: tipos fundamentais. Revista de Administração de Empresas. São Paulo, v. 35, n. 3. p. 20-29, mai/jun, 1995.

GUERREIRO, Evandro P. Cidade digital: infoinclusão social e tecnologia em rede. São Paulo: Senac, 2006.

GUERRINI, Fábio M. Taxonomia das formas organizacionais de produção a partir do recorte analítico de redes de empresas. In: FUSCO, José Paulo A. (org.). Redes Produtivas e Cadeias de Fornecimento. São Paulo: Arte \& Ciência, 2005.

HADLEY, Arthur T. Railroad Transportation: Its History and its Laws. Charleston: BiblioLife, 2009.

HAIR, Joseph F. et at. Fundamentos de métodos de pesquisa em administração. Porto Alegre: Bookman, 2005.

HAMM, Steve. Bangalore tiger: how Indian tech upstart Wipro is rewriting the rules of global competition. New York: McGraw-Hill, 2007.

HAYASHI, Maria Cristina P. I. et al. Indicadores de CT\&I no pólo tecnológico de São Carlos primeiras aproximações. Revista Digital de Biblioteconomia e Ciência da Informação. Campinas, v. 3, n. 2, p. 17-30, jan. 2006.

HOBSBAWN, Eric J. A era dos impérios (1875-1914). Rio de Janeiro: Paz e Terra, 2003.

HOBSBAWN, Eric J. A era das revoluções: Europa, 1789-1848. São Paulo: Paz e Terra, 2006.

HONADLE, George. How context matters: linking environmental policy to people and place. West Hartford: Kumarian, 1999.

HOWELLS, J.R.L. Tacit Knowledge, Innovation and Economic Geography. Urban Studies, v. 1, n. 39, p. 871-884, 2002. 
IBGE. Tabelas de resultados 2003-2007. Brasília DF, 2008. Disponível em: $<$ http://www.ibge.gov.br>. Acesso em: 18 out. 2008.

JOIA, Luiz Antonio. Geração de modelos teóricos a partir de estudos de casos múltiplos: da teoria à prática. In: VIEIRA, Marcelo Milano Falcão; ZOUAIN, Deborah Moraes. Pesquisa qualitativa em administração. p. 123-149. Rio de Janeiro: FGV, 2006.

KAMDAR, Mira. Planeta Índia: a ascensão turbulenta de uma nova potência global. Rio de Janeiro: Agir, 2008.

KEELEY, Brian. Human Capital: How what You Know Shapes Your Life. New York: OECD, 2007.

KEKLIK, Mümtaz. Schumpeter, Innovation and Growth: Long-cycle Dynamics in the Post-WWII American Manufacturing Industries. Farnham: Ashgate Publishing, 2003.

KONDRATIEFF, Nicolai; DANIELS, Guy. The Long Wave Cycle. New York: Richardson \& Snyder, 1984.

KOSCHATZKY, Knut. Räumliche Aspekte im Innovationsprozess: Ein Beintrag zur neuen Wirtschaftsgeografie ais Sicht der regionalen Innovationforschung. München: Lit, 2001.

KOTLER, Philip; JATUSRIPITAK, Somkid; MAESINCEE, Suvit. O Marketing das Nações. São Paulo: Futura, 1997.

KRUGMAN, Paul. Globalização e Globobagens. Rio de Janeiro: Campus, 1999.

LASTRES, Helena M.M; CASSIOLATO, José Eduardo. Globalização e os sistemas de inovação no Mercosul nos anos 90: implicações para políticas. In: CASTRO, Nadya; GUIMARÃES, Nadya Araujo; MARTIN, Scott (Orgs.). Competitividade e desenvolvimento: atores e instituições locais. p. 127-148. São Paulo: SENAC, 2001.

LASTRES, Helena M.M.; CASSIOLATO, José Eduardo. Políticas para arranjos produtivos locais no Brasil. In: OLIVEIRA, Fátima B. (Org.). Política de gestão pública integrada. p. 108-138. Rio de Janeiro: FGV, 2009.

LAURINDO, Fernando José Barbin et al. O Papel da Tecnologia da Informação nas Organizações. Gestão \& Produção. v. 8, n. 2, p. 160-179, ago. 2001.

LÉCUYER, Christophe. Making Silicon Valley: Innovation and the Growth of High Tech, 1930-1970. Cambridge: MIT Press, 2006.

LEOPOLDSEDER, Hannes. Ten indications of an emerging computer culture. In: DRUCKREY, T. (ed.). Ars Eletronica: Facing the Future - A Survey of Two Decades. Cambridge: MIT Press, 1999.

LINTON, Ralph. The Cultural Background of Personality. Londres: Routledge \& Kegan Paul Ltd., 1952. 
LOJKINE, Jean. Revolução Informacional. São Paulo: Cortez, 2002.

LUCAS, Henry C. Information Technology and the Productivity Paradox: Assessing the Value of Investing in IT. New York: Oxford University Press US, 1999.

MALONE, Michael S. Bill \& Dave: How Hewlett and Packard Built the World's Greatest Company. San Francisco: Portfolio, 2007.

MALVINO, Albert Paul. Eletrônica. São Paulo: McGraw-Hill, 1987.

MANSELL, Robin. The Oxford handbook of information and communication technologies. New York: Oxford University Press, 2007.

MANSFIELD, Roger. Changes in Information Technology, Organizational Design and Managerial Control. In: PIERCY, Nigel (Ed.). The Management Implications of New Information Technology. p. 216-230. New York: Taylor \& Francis, 1984.

MARSHALL, Alfred. Princípios de Economia. São Paulo: Victor Civita, 1982.

MARTINELLI, Dante P; JOYAL, André. Desenvolvimento Local e o Papel das Pequenas e Médias Empresas. São Paulo: Manole, 2004.

MARX, Karl. O Capital: Crítica da Economia Política. Livro 1, v. 1. Rio de Janeiro: Civilização Brasileira, 2008.

MATOS, José Gilvomar R; MATOS, Rosa Maria B; ALMEIDA, Josimar Ribeiro de. Análise do Ambiente Corporativo. São Paulo: E-Papers Serviços Editoriais, 2007.

MATTELART, Armand; MATTELART, Michèle. História das Teorias da Comunicação. São Paulo: Loyola, 1999.

MEDEIROS, José A.S. Pólos, parques e incubadoras: a busca da modernização e competitividade. Brasília: CNPq; IBICT; SENAI, 1992.

MEHRA, Kavita. Regional Innovations and the Economic Competitiveness in India. In: SHAVININA, L.V. (Ed.). The International Handbook on Innovation. Londres: Elsevier, 2003.

MELANIPHY, John C. Commercial \& Industrial Condominiums. Michigan: Urban Land Institute, 1976.

MICHALET, Charles-Albert. O que é mundialização? Pequeno tratado para uso dos que ainda não sabem se devem ser a favor ou contra. São Paulo: Loyla, 2003.

MINAYO, Cecília de Souza. Pesquisa Social: teoria, método e criatividade. Petrópolis: Vozes, 1999.

MIRANDA, Luciano. Pierre Bourdieu e o Campo da Comunicação: Por uma teoria da comunicação praxiológica. Porto Alegre: EDIPUCRS, 2005. 
MIRANDA, Roberto Campos da Rocha. O uso da informação na formulação de ações estratégicas pelas empresas. Ciência da Informação, vol. 28, n. 3, p.286-292, Set.-Dez. 1999.

MUNHALL, Patrícia L; CHENAIL, Ronald J. Qualitative Research Proposals and Reports: A Guide. Boston: Jones \& Bartlett, 2007.

NAMBIAR, Sriram. The influence of Aristotelian Logic on Boole's Philosophy of Logic: the reduction of hypotheticals to categoricals. In: GASSER, James (Org.). A Boole Anthology: Recent and Classical Studies in the Logic of George Boole. p. 217-239. New York: Springer, 2000.

OLIVEIRA, Priscila E.F. Pregão Eletrônico: Inovações e Tendências nas Licitações Públicas. Maceió: UFAL, 2007.

OZ, Effy. Information technology productivity: in search of a definite observation. Information \& Management. v. 42, n. 6, p. 789-798, set. 2005.

PATTON, Michael Quinn. Qualitative Research and Evaluation Methods. New York: Sage, 2002.

PAVANI, Claudia. O Capital de Risco no Brasil: Conceito, Evolução, Perspectivas. Rio de Janeiro: E-Papers, 2003.

PECKHAM, John M. A master guide to income property brokerage: boost your income by selling commercial and income properties. Hoboken, NJ: John Wiley \& Sons, 2006.

PEREIRA, Caio Mário da S. Instituições de Direito Civil. v. 4. Ed. 19. Rio de Janeiro: Forense, 2006.

PEREIRA, Paulo A.S. Rios, redes e regiões: a sustentabilidade a partir de um enfoque integrado dos recursos terrestres. Porto Alegre: AGE, 2000.

PORTER, Michael E. A Vantagem Competitiva das Nações. São Paulo: Ed. Campus, 1992.

PORTER, Michael E. On Competition. Cambridge: Harvard Business School Press, 1998.

POWELL, Walter W. Neither market nor hierarchy: Network forms of organization. Research in Organizational Behavior. v. 1, n. 12, p. 295-336, 1990.

PRASHANTHAM, Shameen. The Internationalization of Small Firms: A Strategic Entrepreneurship Perspective. London: Routledge, 2008.

PUTNAM, Robert. Comunidade e democracia: a experiência da Itália moderna. Rio de Janeiro: FGV, 1996.

RAINHO, João Marcos. Jornalismo freelance: empreendedorismo na comunicação. São Paulo: Summus, 2008. 
REMENYI, Dan; MONEY, Arthur. Research Supervision for Supervisors and their Students. Kidmore End UK: Academic Conferences Ltd., 2004

RITCHIE, Jane; LEWIS, Jane. Qualitative Research Practice: A Guide for Social Science Students and Researchers. New York: Sage, 2003.

ROCKS, Steve; CARSON, David; GILMORE, Audrey. Understanding small business enterprise networking: a qualitative case approach. IN: HINE, Damian; CARSON, David (Orgs.). Innovative Methodologies in Enterprise Research. Cheltenham: Edward Elgar, 2007.

SANTAELlA, Lucia. Cultura e Artes do Pós-Humano: da Cultura das Mídias à Cibercultura. São Paulo: Paulus, 2003.

SANTOS, Regina C.B. Campinas como pólo tecnológico na reestruturação do espaço urbano regional. In: CARLOS, Ana Fani A.; LEMOS, Amália I.G. (Orgs.). Dilemas Urbanos: novas abordagens sobre a cidade. p. 204-211. São Paulo: Contexto, 2005.

SAWYER, Robert K. Social emergence: societies as complex systems. Cambridge: Cambridge University Press, 2005.

SAXBY, Stephen. The Age of Information. London: Macmillan, 1990.

SAXENIAN, AnnaLee. Regional Advantage: Culture and Competition in Silicon Valley and Route 128. Cambridge: Harvard University Press, 1994.

SAXENIAN, AnnaLee. The Bangalore Boom: From Brain Drain to Brain Circulation. In: KENNISTON, Kenneth; KUMAR, Deepak (ed.): Bridging the Digital Divide: Lessons From India. Bangalore: National Institute of Advanced Study, 2000.

SAXENIAN, AnnaLee. The New Argonauts: Regional Advantage in a Global Economy. Cambridge: Harvard University Press, 2006.

SCHILLER, Maria Cristina O. S. Inovação, Redes, Espaço e Desenvolvimento. Rio de Janeiro: E-Papers, 2008.

SCHUMPETER, Joseph Alois. Business Cycles: A theoretical, historical and statistical analysis of the capitalist process. Philadelphia: Porcupine Press, 1982.

SCHUMPETER, Joseph Alois. The Theory of Economic Development: An Inquiry Into Profits, Capital, Credit, Interest, and the Business Cycle. Piscataway: Transaction, 1983.

SEETOH, Kum Chun; ONG, Amanda H.F. Achieving sustainable development through a system of strategic planning and implementation: the Singapore model. In: WONG, Tai-Chee; YUEN, Belinda; GOLDBLUM, Charles. (Eds.). Spatial planning for a sustainable Singapore. p. 113-134. New York: Springer, 2008.

SEN, Amartya K. Development as capability expansion. In: FUKUDA-PARR, Sakiko; KUMAR, A.K. Shiva (Eds.). Reading in Human Development. New Delhi: Oxford University Press, 1989. 
SOUZA, Sidnei Ferreira et al. Ferramentas da Tecnologia da Informação (TI) que auxiliam no levantamento de competências nas empresas. In: ENCONTRO DE ENGENHARIA E TECNOLOGIA DOS CAMPOS GERAIS. 3., 2007, Ponta Grossa. Anais... Ponta Grossa: AEAPG, 2007. Disponível em: < http://www.aeapg.org.br/3eetcg/Anais/ARTIGOS/PDFS/ Administracao-04.pdf>. Acesso em: 15 ago. 2008.

SRINIVAS, Tulasi. Um Encontro com o Destino: Globalização Cultural na Índia. In: BERGER; Peter L.; HUNTINGTON, Samuel P. (Orgs.). Muitas Globalizações: Diversidade Cultural no Mundo Contemporâneo. p. 109-140. Rio de Janeiro: Record, 2004.

STERNBERG, Rolf. Entrepreneurship, Proximity and Regional Innovation Systems. Tijdschrift voor Economische en Sociale Geografie, The Royal Dutch Geographical Society, Oxford, v. 98, n. 5, p. 652-666, 2007.

STIGLITZ, Joseph E. Os Exuberantes Anos 90: uma nova interpretação da década mais próspera da história. São Paulo: Cia das Letras, 2003.

STRAUBHAAR, Joseph D. Comunicação, Mídia e Tecnologia. São Paulo: Cengage Learning, 2004.

SUZIGAN, Wilson; FURTADO, João; GARCIA, Renato; SAMPAIO, Sérgio E.K. Sistemas Locais de Produção: mapeamento, tipologia e sugestões de políticas. In: ENCONTRO NACIONAL DE ECONOMIA, 31., 9-12 dez. 2003, Porto Seguro, BA. Anais... Porto Seguro: ANPEC, 2003. Disponível em : <http://www.anpec.org.br/encontro2003/artigos/E28.pdf>. Acesso em: 25 fev. 2009.

TAVARES, Maria da Conceição. Prefácio. In: DANTAS, Marcos. A Lógica do capital Informação. Rio de Janeiro: Ed. Contraponto, 2002.

THOMAS, G. Scott. Where paychecks are growing fastest. Bizjournals, Washington DC, 4 jun. 2007. Disponível em: <http://www.bizjournals.com/edit_special/52.html>. Acesso em: 12 oct. 2008.

TODARO, Michael P. Economic Development in the Third World. New York: Longman, 1985.

TORKOMIAN, Ana Lúcia Vitale; MEDEIROS, José Avelino. Avaliação do Pólo Tecnológico de São Carlos. Revista de Administração, São Paulo, v. 29, n. 2, p. 40-62, abr./jun. 1994.

UN, United Nations. Human Development Report. 2007/2008.

VALE, Gláucia M.V. Territórios vitoriosos: o papel das redes organizacionais. Rio de Janeiro: Garamond, 2007.

VELHO, Gilberto. Projeto e Metamorfose: Antropologia das Sociedades Complexas. Rio de Janeiro: Jorge Zahar, 1994. 
VENKATARAMAN, Sankaran. Regional transformation through technological entrepreneurship. Journal of Business Venturing. v. 19, n. 1, p. 153-167, jan. 2004.

VIEIRA, Zânia Maria R.A. Metamorfose no Trabalho Industrial: um estudo sobre os impactos da terceirização na cultura organizacional. Rio de Janero: e-Papers, 2009.

WOLFE, Gene. The thinkerings of Robert Noyce: how the Sun Rose in Silicon Valley. Esquire, dez., 1983, p. 346-374.

YIN, Robert K. Case Study Research: Design and Methods. New York: Sage, 2008.

YOUNG, Lúcia Helena B. Imposto de Renda Pessoa Jurídica: Noções Fundamentais. Curitiba: Juruá, 2008.

YUE, Chia S. et al. Growth and Development of the IT Industry in Bangalore e Singapore: A Comparative Study. New Delhi: Sterling, 2001.

ZACARELLI, Sérgio B. Estratégia e Sucesso nas Empresas. São Paulo: Pioneira, 2000. 


\section{APÊNDICE A}

Questões que compõem o roteiro de pesquisa da primeira fase da pesquisa.

1. Como se deu o processo histórico de desenvolvimento do pólo tecnológico?

2. Quais as características econômicas que propiciaram seu surgimento na região?

3. Como se deram as relações entre governos, instituições de ensino, institutos de pesquisa e empreendedores na concepção e implantação do cluster?

4. Qual a relação entre o estabelecimento do cluster e o volume de mão de obra especializada disponível na região?

5. Quais os tipos de relações estabelecidas entre as empresas do pólo de tecnologia e como elas se dão? Existe predominância de algum dos tipos sobre os outros?

6. Há relação de hierarquia, evidenciando um grau de importância de uma empresa frente às outras, nos processos produtivos ou nas diversas relações estabelecidas entre as empresas do cluster?

7. Qual a participação inicial dos pólos tecnológicos nos volumes de negócios de seus setores?

8. Como se estabeleceu a rede de relações entre os agentes do pólo de tecnologia (empresas e pessoas) após o início de suas atividades?

9. Como se dá o fluxo de transferência de conhecimento entre as empresas do mesmo cluster, entre agentes de outros Sistemas Regionais de Inovação e mesmo entre agentes de outros Sistemas Nacionais de Inovação?

10. Entre os sub-setores da Tecnologia da Informação (software, serviços, semicondutores, etc.), quais aqueles que obtiveram destaque entre os empreendimentos estabelecidos no cluster, tanto por seu volume de negócios como por sua excelência em inovações para o mercado?

11. Qual a importância do poder público e da legislação vigente para a manutenção do pólo tecnológico?

12. Qual a posição sócio-econômica da região onde o pólo tecnológico está estabelecido frente ao padrão nacional e aos padrões das regiões dos demais pólos tecnológicos do mesmo setor (limitando-se aos estudados)?

13. Há relação entre os fatores de desenvolvimento social da região com o pólo tecnológico? 
14. Como o pólo tecnológico se integra com o desenvolvimento de pesquisa científica da região que ocupa? Qual sua participação no estabelecimento de implementos educacionais da região? 


\section{APÊNDICE B}

Roteiro de entrevista parta a Segunda Etapa da pesquisa, direcionado à prospecção de informações em campo, frente aos órgão administrativos dos parques tecnológicos das regiões abordadas.

Instituição: Data:

Respondente: Cargo:

1. Como se deu o processo histórico de desenvolvimento do pólo tecnológico?

2. Quais as características econômicas que propiciaram seu surgimento na região?

3. Como se deram as relações entre governos, instituições de ensino, institutos de pesquisa e empreendedores na concepção e implantação do cluster?

4. Qual a relação entre o estabelecimento do cluster e o volume de mão de obra especializada disponível na região?

5. Quais os tipos de relações estabelecidas entre as empresas do pólo de tecnologia e como elas se dão? Existe predominância de algum dos tipos sobre os outros?

6. Há relação de hierarquia, evidenciando um grau de importância de uma empresa frente às outras, nos processos produtivos ou nas diversas relações estabelecidas entre as empresas do cluster?

7. Qual a participação inicial dos pólos tecnológicos nos volumes de negócios de seus setores?

8. Como se estabeleceu a rede de relações entre os agentes do pólo de tecnologia (empresas e pessoas) após o início de suas atividades?

9. Como se dá o fluxo de transferência de conhecimento entre as empresas do mesmo cluster, entre agentes de outros Sistemas Regionais de Inovação e mesmo entre agentes de outros Sistemas Nacionais de Inovação?

10. Entre os sub-setores da Tecnologia da Informação (software, serviços, semicondutores, etc.), quais aqueles que obtiveram destaque entre os empreendimentos estabelecidos no cluster, tanto por seu volume de negócios como por sua excelência em inovações para o mercado? 
11. Qual a importância do poder público e da legislação vigente para a manutenção do pólo tecnológico?

12. Qual a posição sócio-econômica da região onde o pólo tecnológico está estabelecido frente ao padrão nacional e aos padrões das regiões dos demais pólos tecnológicos do mesmo setor (limitando-se aos estudados)?

13. Há relação entre os fatores de desenvolvimento social da região com o pólo tecnológico?

14. Como o pólo tecnológico se integra com o desenvolvimento de pesquisa científica da região que ocupa? Qual sua participação no estabelecimento de implementos educacionais da região? 


\section{APÊNDICE C}

Protocolo de pesquisa (YIN, 2008).

\section{Introdução ao estudo de múltiplos casos e propósito do protocolo}

O estudo de caso que determina esta pesquisa se baseia nas questões elencadas no Apêndice A, no intuito de elucidar se os arranjos produtivos internos dos clusters de TI e as relações estabelecidas entre seus agentes durante seu desenvolvimento são os fatores preponderantes para sua excelência frente ao mercado de tecnologia e sua manutenção sistêmica após a consolidação de sua estrutura, e como esses arranjos e relações ocorrem, problema de pesquisa apresentado no tópico 1.2 dos elementos textuais deste trabalho.

Objetivo Geral: estabelecimento de análise comparativa entre clusters nacionais e internacionais que permita a elucidação do problema de pesquisa envolvendo o modelo de desenvolvimento de pólos regionais de tecnologia da informação e seus resultados frente ao mercado, no âmbito nacional e internacional, principalmente no que se refere ao sucesso de seu desempenho operacional, sucesso econômico e manutenção de sua posição de mercado.

\section{Objetivos Específicos:}

1. Analisar os modelos de desenvolvimento dos pólos tecnológicos internacionais propostos, sendo eles o Vale de Santa Clara (Califórnia) e Bangalore (Índia), identificando fatores preponderantes para sua excelência. Esta análise será fundamentada na vasta bibliografia acadêmica sobre o assunto;

2. Analisar as características dos modelos de desenvolvimento dos dois pólos tecnológicos nacionais escolhidos, em Campinas-SP e São Carlos-SP, no que tange às relações de seus agentes internos constituídas com outros agentes do cluster ou com agentes externos, clientes, governos, parceiros e competidores;

3. Confrontar as análises dos pólos nacionais e internacionais do universo da pesquisa, elaborando uma nova análise das semelhanças e diferenças, traçando uma perspectiva entre o modo de atuação dos agentes dos mesmos e os dados econômicos obtidos sobre as quatro regiões estudadas; 
4. Mapear os sucessos e os insucessos dos modelos estabelecidos, além dos fatores que condicionam a atuação dos agentes no interior do cluster, suas relações e contribuições para o desenvolvimento econômico e social de suas regiões;

\subsection{Resumo da Estrutura Teórica}

Clusters internacionais: estrutura pulverizada de empresas de tamanho variado que estabelecessem relações entre si para interação com o mercado; prevalência da iniciativa privada, apoiada sobre a existência de uma estrutura de instituições expressivas de pesquisa e formação tecnológica na região; grande expressão no mercado em âmbito mundial, em diversos setores da área de TI.

Clusters nacionais: estrutura de poucas empresas pequenas, médias e de grande porte que realizam as operações centrais do arranjo produtivo; dependência do cenário aos grandes agentes centrais do cluster; prevalência de subsídios públicos para prospecção tecnológica; diversas tentativas ainda pouco expressivas de alavancar o empreendedorismo privado por meio de incentivos públicos; expressão considerável no mercado regional e nacional, com pouca influência sobre o mercado internacional.

O que diferencia efetivamente o processo de estruturação interna dos clusters abordados?

\subsection{Papel do Protocolo:}

O protocolo de pesquisa terá a função de guiar o desenvolvimento dos trabalhos, como um referencial pré-estabelecido de procedimentos e parâmetros para o estudo dos quatro casos abordados. Segundo Yin (2008), "o protocolo é uma das melhores formas de aumento da credibilidade da pesquisa de estudo de caso e tem a intenção de guiar o investigador em proceder com a coleta de dados de um estudo de caso" (YIN, 2008, p. 79).

\section{Procedimentos de Coleta de Dados}

\subsection{Revisão Bibliográfica}


A revisão bibliográfica se baseará na escolha de textos de maior relevância acadêmica sobre os clusters abordados. No caso dos clusters internacionais, sobre os quais há extensa disponibilidade de material, haverá a prospecção de maior quantidade de textos no intuito de fornecer subsídios mais concretos para resposta ao roteiro estabelecido no Apêndice A, onde estão dispostas as questões relevantes para a obtenção dos objetivos específicos.

Uma vez extraídas das referências a solução para as questões apresentadas no Apêndice A, será possível a passagem para a prospecção de informações em campo sobre os clusters nacionais abordados.

\subsection{Pesquisa de Campo}

A pesquisa de campo, definida no projeto de pesquisa como a segunda etapa operacional da mesma, se baseará na visita às instituições elencadas para análise.

\subsubsection{Instituições abordadas}

Inicialmente, a pesquisa foi desenhada para a abordagem das instituições responsáveis pela administração dos clusters nacionais:

Campinas: - Ciatec (órgão administrativo do Pólo II de Alta Tecnologia);

São Carlos: - órgão administrativo do ParqTec .

As informações serão coletadas através de entrevista, com gravação do áudio em meio digital, de responsáveis pelas instituições abordadas, tais como dirigentes e administradores. A entrevista se dará no intuito de cumprir o disposto no roteiro estabelecido no Apêndice B para a segunda etapa da pesquisa, mas não se limitará a ele.

Uma vez extraídas as informações conforme estabelecido passar-se-á à análise dos resultados e convergência do mesmo para que possa se extrair um modelo de comportamento que sirva como média para o cluster analisado. Essas informações serão tabuladas para, nas fases posteriores, serem analisadas conforme descrito na metodologia do projeto.

\subsubsection{Procedimentos de entrevista}


As entrevistas ocorrerão no espaço dos clusters abordados, sob a possibilidade de verificar presencialmente as informações de maior relevância do relato dos entrevistados.

Serão entrevistados indivíduos de relevância operacional na administração do cluster, sugerindo-se que estes se sintam a vontade para indicar pontos que considerem relevantes entre os temas abordados pelo entrevistador.

As entrevistas serão gravadas em arquivo sonoro digital e analisadas pelo pesquisador no intuito de levantar informações que elucidem os pontos levantados pela pesquisa.

\section{Questões do Estudo de Caso}

Ver Apêndices A e B

\section{Avaliação}

A avaliação das informações levantadas será realizada através do cruzamento dos dados em planilha constituída dos resultados agregados por cluster analisado. Dessa forma, será possível extrair as diferenças dos modelos analisados, buscando na bibliografia as explicações históricas, sociais e econômicas de cada região que justifiquem os resultados auferidos. 